\title{
Developing a Strategic Process to Reintroduce a Lost Water Way as a Possible Solution for Water Logging: Case study, An Area of Dhaka Metropolitan City
}

Debsree Mandal

demandal@mix.wvu.edu

Follow this and additional works at: https://researchrepository.wvu.edu/etd

Part of the Landscape Architecture Commons

\footnotetext{
Recommended Citation

Mandal, Debsree, "Developing a Strategic Process to Reintroduce a Lost Water Way as a Possible Solution for Water Logging: Case study, An Area of Dhaka Metropolitan City" (2019). Graduate Theses, Dissertations, and Problem Reports. 3758.

https://researchrepository.wvu.edu/etd/3758

This Thesis is protected by copyright and/or related rights. It has been brought to you by the The Research Repository @ WVU with permission from the rights-holder(s). You are free to use this Thesis in any way that is permitted by the copyright and related rights legislation that applies to your use. For other uses you must obtain permission from the rights-holder(s) directly, unless additional rights are indicated by a Creative Commons license in the record and/ or on the work itself. This Thesis has been accepted for inclusion in WVU Graduate Theses, Dissertations, and Problem Reports collection by an authorized administrator of The Research Repository @ WVU. For more information, please contact researchrepository@mail.wvu.edu.
} 


\section{Developing a Strategic Process to Reintroduce a Lost Water Way as a Possible Solution for Water Logging: Case study, An Area of Dhaka Metropolitan City}

Debsree Mandal

demandal@mix.wvu.edu

Follow this and additional works at: https://researchrepository.wvu.edu/etd

Part of the Landscape Architecture Commons

\footnotetext{
Recommended Citation

Mandal, Debsree, "Developing a Strategic Process to Reintroduce a Lost Water Way as a Possible Solution for Water Logging: Case study, An Area of Dhaka Metropolitan City" (2019). Graduate Theses, Dissertations, and Problem Reports. 3758.

https://researchrepository.wvu.edu/etd/3758

This Thesis is protected by copyright and/or related rights. It has been brought to you by the The Research Repository @ WVU with permission from the rights-holder(s). You are free to use this Thesis in any way that is permitted by the copyright and related rights legislation that applies to your use. For other uses you must obtain permission from the rights-holder(s) directly, unless additional rights are indicated by a Creative Commons license in the record and/ or on the work itself. This Thesis has been accepted for inclusion in WVU Graduate Theses, Dissertations, and Problem Reports collection by an authorized administrator of The Research Repository @ WVU. For more information, please contact researchrepository@mail.wvu.edu.
} 


\title{
Developing a Strategic Process to Reintroduce a Lost Waterway as a Possible Solution for Waterlogging: Case study, An Area of Dhaka Metropolitan City
}

\author{
Debsree Mandal
}

\begin{abstract}
Thesis submitted
To the Davis College of Agriculture, Natural Resources and Design At West Virginia University

In partial fulfillment of the requirements for the degree of
\end{abstract}

Master of Landscape Architecture in Landscape Architecture Department
Stefania Staniscia, Ph.D. Committee Chairperson. Hodjat Ghadimi, Ph.D. Michael Strager, Ph.D.

Department of Landscape Architecture

School of Design and Community Development, Division of Resource Management

\author{
Morgantown, West Virginia \\ 2019
}

Keywords: Waterlogging, Lost water way, Urban water bodies, Dhaka Copyright 2019 Debsree Mandal 


\title{
Abstract
}

\section{Developing a Strategic Process to Reintroduce a Lost Waterway as a Possible Solution for Waterlogging: Case study, An Area of Dhaka Metropolitan City}

\author{
Debsree Mandal
}

During the rainy season, Dhaka, the capital city of Bangladesh, faces tremendous rainfall which is annually $1600 \mathrm{~mm}-2000 \mathrm{~mm}$ and it is increasing at a rate of $55.90 \mathrm{~mm} / \mathrm{year}$. So, in monsoon, some areas of this city suffer from water logging which continues from 3 hours up to two feet to more than one day. It increases the hazards for everyday life for the city dwellers, especially in the transportation and working sectors of the city which follows other socio-economic, health and environmental problem.

Dhaka is one of the most populous cities in the world. This area is almost flat and close to sea level. So, Dhaka is susceptible to flood during monsoon. Historically Dhaka has a network of natural canals which was connected to big rivers to serve as a natural drainage system for the rain runoff. These canals served as a good means of transportation also. Gradually, in the course of time this natural drainage system has been almost destroyed.

Due to overpopulation, the increasing demand for land and unplanned rapid urbanization causes the destruction and discontinuation of water channels. As a result, waterlogging occurs during the rainy season in various part of the city. Demolition of these water channels and depressions not only affects the natural process of land formation but also alter the ecosystem.

This study aims to develop a process to reintroduce a previous waterway in Dhaka city as a possible solution of waterlogging. So, at first, changes in wetlands and water bodies are analyzed through studying the geo-morphological history of Dhaka and ArcGIS analysis to find out the potential water bodies which are needed to be revived or developed further. Hydrological analysis in ArcMap has been done here to show the water flow direction which is derived from the DEM (digital elevation model) of Dhaka city. Then, one disconnecting point is chosen to develop a process for introducing waterway as a possible solution of waterlogging which will also serve as a transportation system.

The study only provides a generic idea to verify an idea to resolve the issue of urban waterlogging. The most positive aspect of this proposal is to protect the urban water bodies and convert those as a mean of the transportation system. Without protecting the wetlands and water bodies the drainage system of Dhaka will collapse and inundation will increase. If the method works then, it will be a key factor to make other dead water lines alive for Dhaka City. 


\section{ACKNDWLEDGEMENTS}

The author wishes to acknowledge the following people for their time, advice, knowledge, support and criticism throughout the completion of this thesis work successfully.

\section{From West Virginia University}

Stefania Staniscia - A mentor and motivator whose expectations and supports makes me go further. Hodjat Ghadimi - A motivator Michael Strager- A critic

Peter Butler- An all-time mentor for last three years studying here and a supporter to understand the situation during doing this thesis work giving no pressure for the research assistantship work with him. I am thankful for that and feel lucky to get the opportunity to work with him during my last semester here. I will try to fill up the gap.

Timothy Warner- A helpful person

Nicolas Pierre Zegre- A helpful person

Dianna Spring- A friend in need is a friend indeed, with positive influence.

From Morgantown

Md Abu Zafer Siddik

Shofiq Ahmed

Nashid Mirza

Udday Shankur Datta- A Supporter and a motivator until the end with valuable resources, except some exceptions.

From Bangladesh

Pulak Roy

Iftekhar Rahman Rabib

Nusrat Tasfia

Tamanna Afroz

Sharmin Ahmed Zeba

Qazi Azizul Mowla- My former mentor

Patrick D'Rozario- My former mentor, whose continuous support gives me the strength to come forward for higher study.

At last, I want to thank God to give me patience and strength and such highly supportive parents (Dilip Ranjan Mandal and Jyotsna Rani Mandal) and brother (Debjyoti Mandal) who are always there for me for any kind of situation during this study period. I also would like to thank my uncle Swapan Sikder. 


\section{TABLE DF CDNTENTS}

$\begin{array}{ll}\text { Abstract } & \text { ii }\end{array}$

$\begin{array}{ll}\text { Acknowledgement } & \text { iii }\end{array}$

Table of Contents iv

List of Figures $\quad$ vi

$\begin{array}{lll}\text { Chapter 1. Introduction } & 1\end{array}$

1.1 Background 1

1.2 Statement of problems 11

1.3 Objectives 11

1.4 Research question 11

$\begin{array}{lll}1.5 & \text { Methodology } & 12\end{array}$

1.6 Literature Review 13

$\begin{array}{llll}\text { Chapter } & \text { 2. Inventory and Analysis at Metropolitan Scale } 18\end{array}$

2.1 Geomorphology 18

2.2 Weather 19

2.3 Groundwater level 24

2.4 Change in wetland and water body 25

2.5 Finding out lost waterway connection 32

2.6 Water Flow Direction 34

2.7 Finding out the site area $\quad 39$

$\begin{array}{llll}\text { Chapter } & 3 . & \text { Site Analysis } & 41\end{array}$

3.1 Location Description 41

3.2 Historical background of the study area and 48 present discussion

3.3 Infrastructure Study 51

3.4 Road Connectivity Analysis $\quad 51$ 
3.5 Census Data 54

3.6 Finding Catchment Area 54

3.7 Catchment area condition 55

3.8 Surface Runoff volume calculation $\quad 58$

Chapter

4. Case studies $\quad 60$

4.1 Pymmes Brook, Edmonton, London 60

4.2 River Quaggy at Sutcliffe Park 61

4.3 Cheong Gye Cheon Restoration Project 63

Chapter

5. Concept Design 65

5.1 Concept

65

Chapter

6. Design Criteria $\quad 67$

6.1 Size of Waterway 67

6.2 Facilities beside the waterway 67

Chapter

7. Detailed Design $\quad 68$

7.1 Proposed Design 68

7.2 Perspective 77

7.3 Plant Selection $\quad 82$

7.4 List of fruit plants $\quad 83$

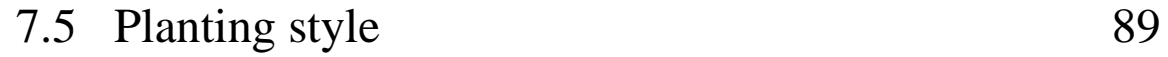

$\begin{array}{lr}\text { Conclusion } & 90\end{array}$

$\begin{array}{lr}\text { References } & 91\end{array}$ 


\section{LIST DF FIGURES}

Figure

Figure Title

Figure 1. Location of Bangladesh

Figure 2.

Map showing Division of Bangladesh

Figure 3.

Map showing the Rivers of Bangladesh

Figure 4.

Map showing the River System of Bangladesh

Figure 5.

Map showing the inundation area of Bangladesh

Figure 6. $\quad$ Map showing the division of area due to different types of flood $\quad 7$

Figure 7

Map showing Mean Annual rainfall of Bangladesh 8

Figure 8.

Map showing the Dhaka City area

Figure 9.

Dhaka during 1998 flood

Figure 10.

Waterlogging

Figure 11.

Dhaka during 1998 flood

Figure 12.

$\begin{array}{ll}\text { Street conditions of Dhaka city during waterlogging } & 10\end{array}$

Figure 13.

Diagram of Methodology

$\begin{array}{llr}\text { Figure 14. } & \text { Components of drainage basin } & 14 \\ \text { Figure 15. } & \text { Delineated watershed } & 15\end{array}$

Figure 16. Water flow direction network $\quad 16$

Figure 17. Showing numeric value of every cell 16

Figure 18. Flow Direction: Eight Direction Pour-Point Model 16

Figure 19. $\quad$ Flow Direction Map 17

$\begin{array}{ll}\text { Figure 20. Steps of using Hydrology tools in Arc Map } & 17\end{array}$

$\begin{array}{ll}\text { Figure 21. Geomorphological Map of Dhaka } & 18\end{array}$

Figure 22. Legends of Geomorphological map of Dhaka 19

Figure 23. Growth pattern of Dhaka city 19

$\begin{array}{ll}\text { Figure 24. Monthly diurnal average } & 20\end{array}$

$\begin{array}{lll}\text { Figure 25. Temperature range chart } & 20\end{array}$

$\begin{array}{lll}\text { Figure 26. } & \text { Dry bulb temperature graph } & 21\end{array}$

$\begin{array}{lll}\text { Figure 27. } & \text { Relative humidity graph } & 21\end{array}$

Figure 28. Wind velocity $\quad 22$

Figure 29. Prevailing wind in relation with Average rainfall and average wind 23 temperature

$\begin{array}{lll}\text { Figure 30. } & \text { Average daily rainfall } & 23\end{array}$

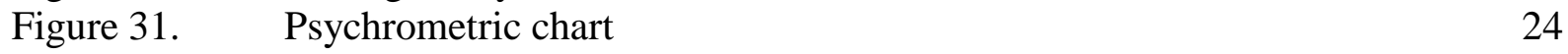

Figure 32. Depth of ground water table at the year of 1980, 1990 and $1995 \quad 25$

Figure 33. Depth of ground water table at the year of 2000, 2005 and $2010 \quad 25$

$\begin{array}{ll}\text { Figure 34. } & \text { Map of Dhaka canals }\end{array}$

Figure 35. Changes in wetlands and water bodies 28

Figure 36. $\quad$ Future prediction of changes in wetlands and water bodies 29

Figure 37. Wetlands in Dhaka metropolitan area between 1978 and $2009 \quad 30$

Figure 38. Chart showing decreasing condition of wetlands and Map showing the 31 comparison of wetland loss between 1978 and 2009

$\begin{array}{lll}\text { Figure 39. Wetland condition at } 2019 & 31\end{array}$ 
Figure 40. Proposed location for reopen and revitalize the water channels 33

Figure 41. $\quad$ Flow direction map $\quad 34$

$\begin{array}{lll}\text { Figure 42 Water flow direction diagram } & 35\end{array}$

Figure 43. Diagram of flow direction method $\quad 35$

Figure 44. Map of water basin for the Dhaka city 36

$\begin{array}{lll}\text { Figure 45. } & \text { Diagram of creating water basin } & 37\end{array}$

$\begin{array}{lll}\text { Figure 46. } & \text { Map of showing streamlines } & 38\end{array}$

$\begin{array}{lll}\text { Figure 47. Inundation scenario near study area } & 39\end{array}$

$\begin{array}{lll}\text { Figure 48. } & \text { Map of showing lost waterways } & 40\end{array}$

Figure 49. $\quad$ Location of study area 41

$\begin{array}{lll}\text { Figure 50. } & \text { Showing the density of the area } & 42\end{array}$

Figure 51. Showing the location of existing water body at the both end of the study 43 area

Figure 52. Showing existing road condition of the study area 43

Figure 53. Divide the area to show different situation 44

$\begin{array}{lll}\text { Figure 54. } & \text { Showing situation for type } 1 & 45\end{array}$

Figure 55. Images of typical condition $\quad 45$

$\begin{array}{lll}\text { Figure 56. } & \text { Showing situation for type 2 } & 46\end{array}$

Figure 57. Images of Bridge area where two buildings are connected 46

$\begin{array}{lll}\text { Figure 58. } & \text { Showing situation for type } 3 & 47\end{array}$

Figure 59. Images of road side shops and activity on road divider space $\quad 47$

$\begin{array}{lll}\text { Figure 60. } & \text { Showing situation for type } 4 & 48\end{array}$

$\begin{array}{lll}\text { Figure 61. Images of west end and east end of the study area } & 48\end{array}$

Figure 62. Dhaka's Khals from 1955 to $2009 \quad 49$

Figure 63. Map showing culvert condition at study area $\quad 50$

Figure 64 Existing Site Plan with Building Typology 51

$\begin{array}{lll}\text { Figure 65. Road connectivity analysis throughout the city scale } & 52\end{array}$

Figure 66. Road connectivity analysis only considering major roads which are 53 connected to the study area.

Figure 67. Catchment area for study area $\quad 54$

Figure 68. ArcGIS flow diagram for generating catchment area $\quad 55$

Figure 69. Landcover map with Building typology 56

$\begin{array}{lll}\text { Figure 70. } & \text { Map showing power installation points and wards } & 57\end{array}$

$\begin{array}{lll}\text { Figure 71. } & \text { Map showing utilities points } & 58\end{array}$

$\begin{array}{ll}\text { Figure 72. } & 59\end{array}$

$\begin{array}{lll}\text { Figure 73. } & \text { Location Map Culvert Area }\end{array}$

Figure 74. Before image of de-culverting and after image of de-culverting 60

$\begin{array}{lll}\text { Figure 75. } & \text { Showing river network } & 61\end{array}$

$\begin{array}{lll}\text { Figure 76. } & \text { Before image of Sutcliffe park } & 62\end{array}$

$\begin{array}{lll}\text { Figure 77. } & \text { After image of Sutcliffe park } & 62\end{array}$

$\begin{array}{lll}\text { Figure 78. } & \text { Sutcliffe Park Flood defense aspects } & 63\end{array}$

Figure 79. Open water providing space to manage flood risk and provide access to 63 nature

$\begin{array}{lll}\text { Figure 80. } & \text { Cheonggye Highway (1967 1971) } & 63\end{array}$

$\begin{array}{lll}\text { Figure 81. Cheonggye Highway in 1990s } & 64\end{array}$

$\begin{array}{lll}\text { Figure 82. } & \text { Safety problem in structure portion } & 64\end{array}$ 
Figure 83. Before the restoration has done and after the restoration has done 65

Figure 84. Conceptual sectional diagram 66

$\begin{array}{lll}\text { Figure 85. } & \text { Top view proposed Plan } & 68\end{array}$

$\begin{array}{lll}\text { Figure 86. } & \text { Type 1, Plan view of typical condition } & 69\end{array}$

$\begin{array}{lll}\text { Figure 87. Sectional view of typical condition } & 70\end{array}$

$\begin{array}{lll}\text { Figure 88. } & \text { Typical condition of waterway side } & 70\end{array}$

$\begin{array}{lll}\text { Figure 89. } & \text { Bio-swale portion } & 71\end{array}$

$\begin{array}{lll}\text { Figure 90. } & \text { Type 2, Plan view of Pedestrian bridge condition } & 72\end{array}$

$\begin{array}{lll}\text { Figure 91. } & \text { Sectional View of Type 2 } & 73\end{array}$

$\begin{array}{lll}\text { Figure 92. } & \text { Bridge for Pedestrian Access } & 73\end{array}$

$\begin{array}{lll}\text { Figure 93. } & \text { Bridge for Universal Pedestrian Access } & 74\end{array}$

Figure 94. $\quad$ Type 3, Plan view of Pedestrian side stall portion 75

$\begin{array}{lll}\text { Figure 95. } & 76\end{array}$

$\begin{array}{lll}\text { Figure 96. } & \text { Place for riding water vehicle } & 76\end{array}$

Figure 97. Connection point between Panthapath and Mirpur road area 77

$\begin{array}{lll}\text { Figure 98. } & \text { Night view at waterway side }\end{array}$

$\begin{array}{lll}\text { Figure 99. } & \text { Lake side stall view } & 78\end{array}$

$\begin{array}{lll}\text { Figure 100. } & \text { Using water vehicle } & 78\end{array}$

Figure 101. Bridge for vehicular access at the connection point of Panthapath and 79 Green road

$\begin{array}{lll}\text { Figure 102. } & \text { Bridge for universal pedestrian access } & 79\end{array}$

$\begin{array}{ll}\text { Figure 103. } & \text { Vehicle can enter here for emergency purpose }\end{array}$

Figure 104. Lake side view in-front of Bashundhara City Shopping Complex $\quad 80$

$\begin{array}{lll}\text { Figure 105. } & \text { Lake side view from vehicular bridge } & 81\end{array}$

$\begin{array}{lll}\text { Figure 106. } & \text { Vendor shop from Pedestrian portion } & 81\end{array}$

$\begin{array}{lll}\text { Figure 107. Jackfruit tree and fruits } & 84\end{array}$

$\begin{array}{lll}\text { Figure 108. } & \text { Mangoo tree and fruits } & 84\end{array}$

$\begin{array}{lll}\text { Figure 109. } & \text { Litchi Tree and fruits } & 84\end{array}$

$\begin{array}{lll}\text { Figure 110. Watermelon Plant and fruit } & 85\end{array}$

Figure 111. $\quad$ Burmese grape tree and fruit, Pineapple plants and fruits $\quad 85$

Figure 112. $\quad$ Yellow mombin tree and fruits, Papaya plants and fruits $\quad 85$

Figure 113. Guava tree and fruits, Blackberry tree $\quad 86$

Figure 114. Blackberry fruits, Lemon tree and fruits $\quad 86$

Figure 115. Wood Apple tree and fruits, Coconut plants $\quad 86$

$\begin{array}{lll}\text { Figure 116. } & \text { Elephant Apple tree and fruits } & 86\end{array}$

$\begin{array}{lll}\text { Figure 117. } & \text { Star Fruit tree and fruits } & 87\end{array}$

$\begin{array}{lll}\text { Figure 118. } & \text { Amla tree and fruits } & 87\end{array}$

$\begin{array}{lll}\text { Figure 119. } & \text { Wood apple fruits and water apple fruits } & 87\end{array}$

$\begin{array}{lll}\text { Figure 120. } & \text { Pomegranate tree and fruit, Orange fruits } & 88\end{array}$

$\begin{array}{lll}\text { Figure 121. } & \text { Orange fruit tree, Banana plants } & 88\end{array}$

$\begin{array}{lll}\text { Figure 122. Jujube fruit tree and fruits } & 88\end{array}$

$\begin{array}{lll}\text { Figure 123. } & \text { Planting style } & 89\end{array}$

$\begin{array}{ll}\text { Figure 124. } & \text { Planting style }\end{array}$ 


\section{CHAPTER 1 INTRODUCTION}

\subsection{Background}

In the tropical region where monsoon causes heavy rainfall is drained out naturally through streamriver networks and wetlands. These wetlands serve as natural retention storage. Unplanned urbanization hampered this natural drainage system and causes sudden inundation and waterlogging (Sultana et al. 2009).

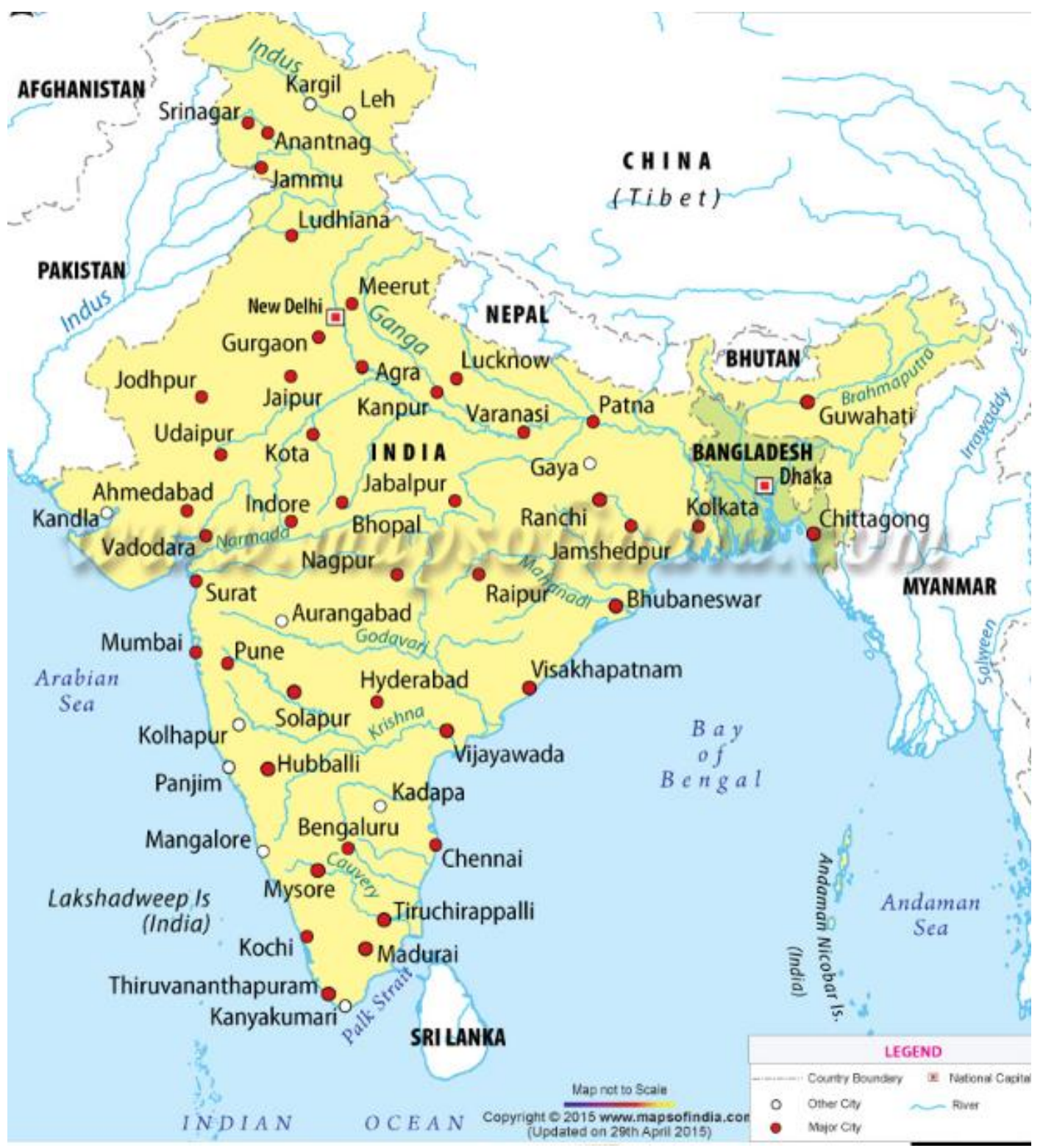

Figure 1. Location of Bangladesh (source: createalist.info, 2018) 
Dhaka is the Capital city of Bangladesh. It is situated almost at the center of Bangladesh (Figure 2). In the world map (Figure 1), Bangladesh is situated in both northern and eastern hemispheres. The three parts are surrounded by land surface except at the south part of the country. Bangladesh is situated at the lower land portion rather than other surrounding countries. It means, water comes from uphill will flow throughout the surface of Bangladesh, as the Bay of Bengal lies at the south.

Bangladesh is the continent of Asia and surrounded by the Bay of Bengal, the countries of India and Myanmar. It covers 130,170 square kilometers of land and 18,290 square kilometers of water, which makes it the 96th largest nation in the world with a total area of 148,460 square kilometers.

The current population of Bangladesh is 167,409,431 (Bangladesh population, 2019). The population density in Bangladesh is 1291 per square kilometer (Bangladesh population, 2019). Based on the number of the population it ranks $8^{\text {th }}$ in the list of countries.

Bangladesh is called the country of the river (Figure 3). Almost all the major cities, towns and commercial centers are located on the bank of rivers. Dhaka is situated on the bank of river Buriganga. This river network serves as a drainage system and transport system of Bangladesh.

Bangladesh has one of the largest river networks in the world with a total number of about 700 rivers including tributaries, which have a total length of about $24,140 \mathrm{~km}$. They consist of tiny hilly streams, winding seasonal creeks, muddy canals (khals), some magnificent rivers and their tributaries.

Bangladesh has mainly four major river systems - the Brahmaputra-Jamuna, the Ganges-Padma, the Surma-Meghna, and the Chittagong Region river system (Figure 4). However, Brahmaputra is the $22 \mathrm{nd}$ longest $(2,850 \mathrm{~km})$ and the Ganges is the 30 th longest $(2,510 \mathrm{~km})$ river in the world.

These rivers also bring the possibility of being flooded or inundated. Flood brings the fertile soil for agriculture field. In some cases, flood retains the natural ecosystem of the country. Sufferings of people are not acceptable, but if precautions can be taken, flood can be a useful event for this country.

So, Bangladesh is one of the most flood-prone zones in the world. The depth of flood water level can reach more than 3m. Figure 5 shows the depth of inundation area of Bangladesh in 2017. There are several causes of flood. The important causes are river flow and heavy rainfall, climate change, etc.

The mean annual rainfall map (Figure 7) shows that there is no mean annual rainfall less than 1000 $\mathrm{mm}$. while the maximum highest mean annual rainfall is more than $5000 \mathrm{~mm}$ at north-east portion of the country. It can be said that this vast rainfall in one of a reason for the sudden flash flood if there is no proper storm water management system or water disposal network towards the main water bodies.

In the present time, many big cities of Bangladesh suffer due to sudden flood during the rainy season. Sometimes only one-hour rain can cause waterlogging. It is now a big concern for the government of Bangladesh to deal with this problem. 


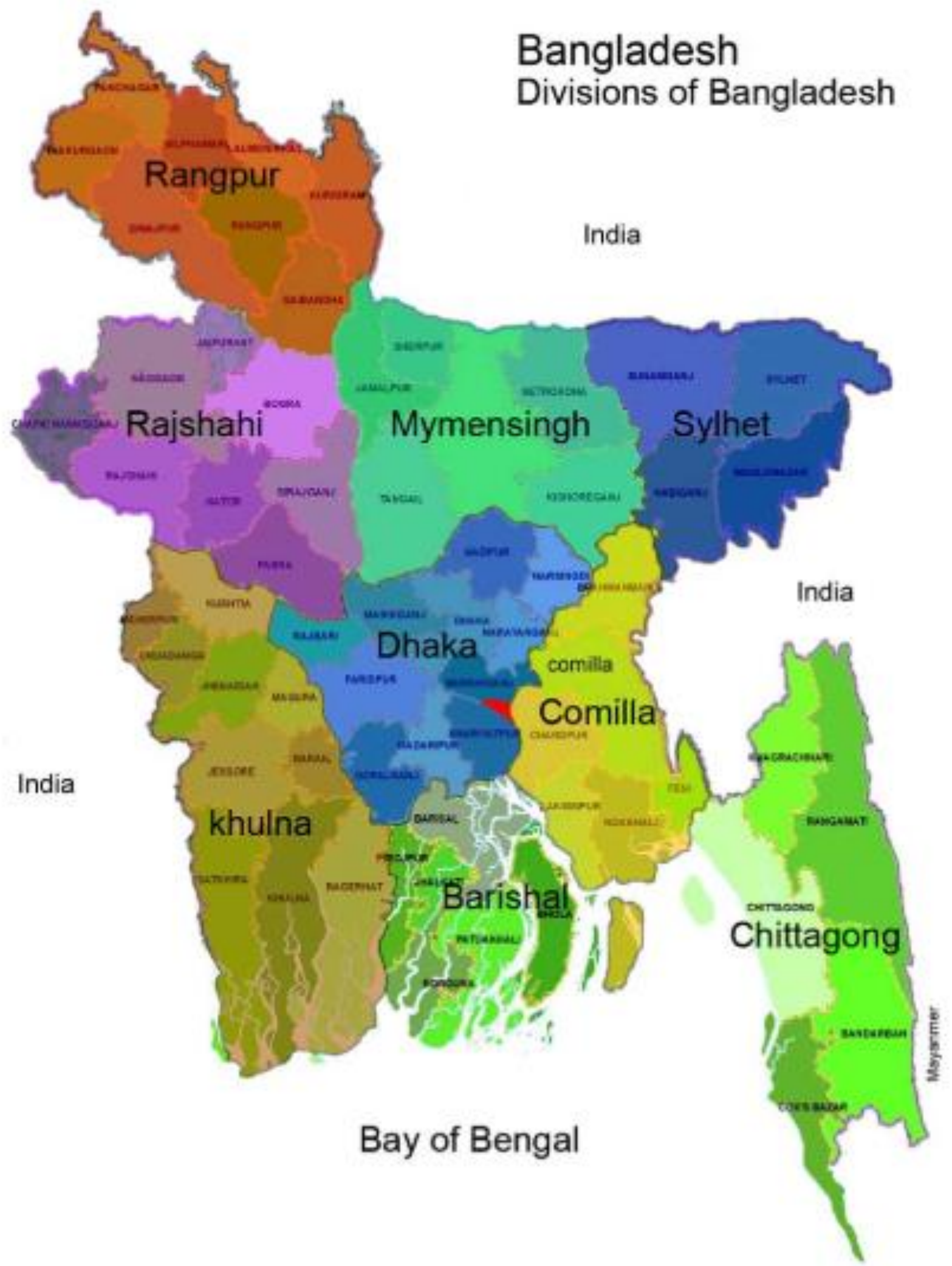

Figure 2. Map showing Division of Bangladesh (source: Bangladesh all information, 2018) 


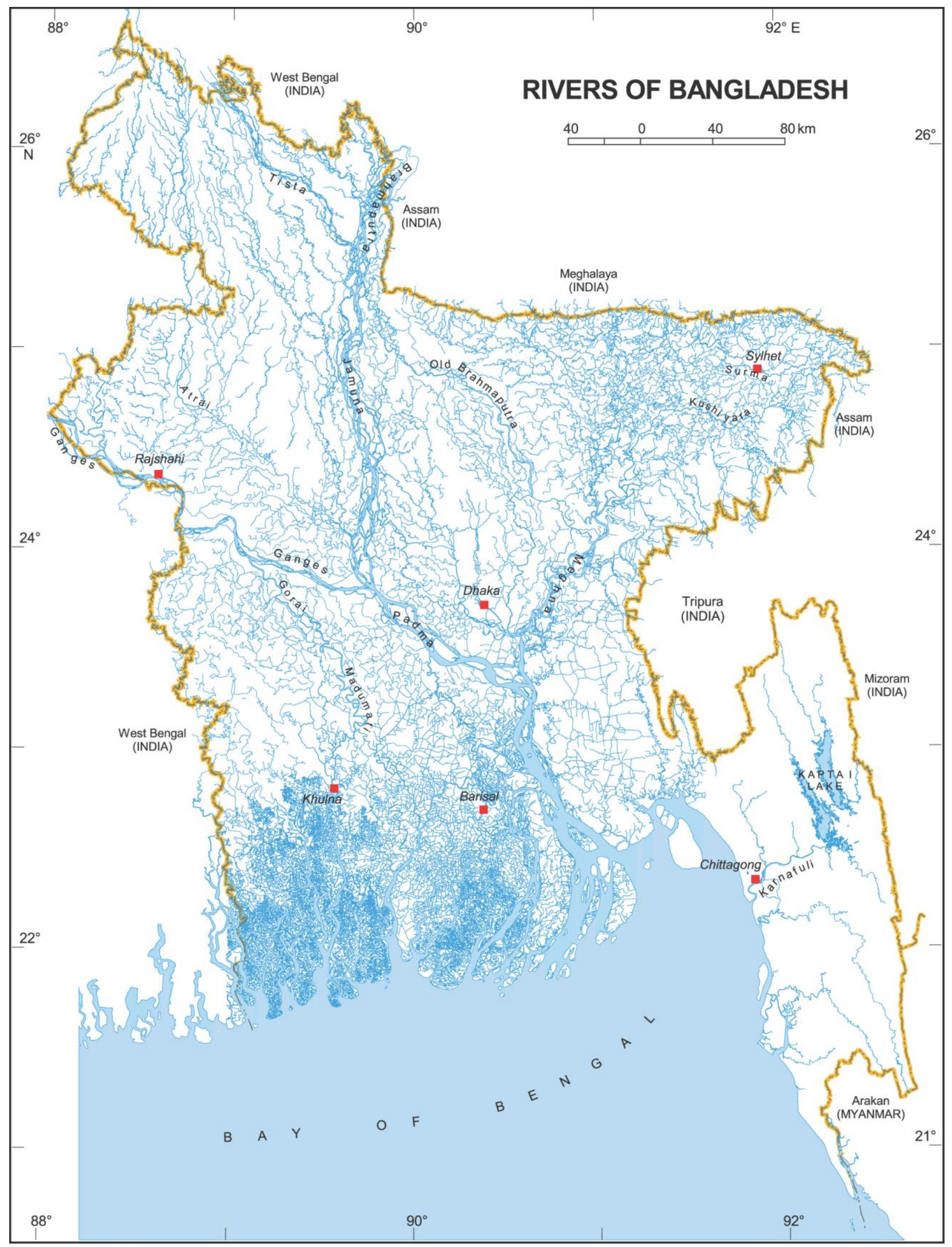

Figure 3. Map showing the Rivers of Bangladesh (source: Dilip Kumar Datta, 2015) 


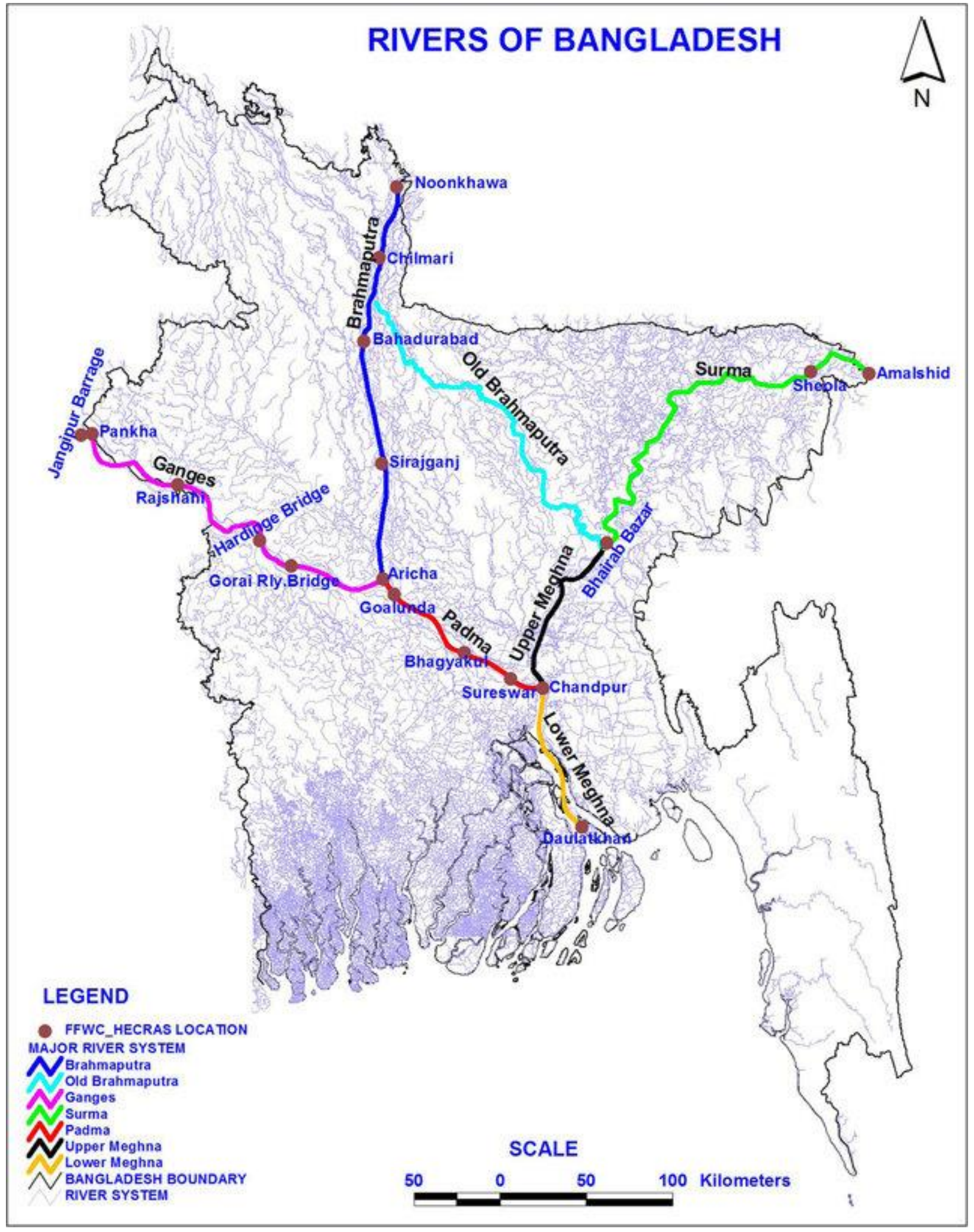

Figure 4. Map showing the River System of Bangladesh (Hossain et al. 2013) 


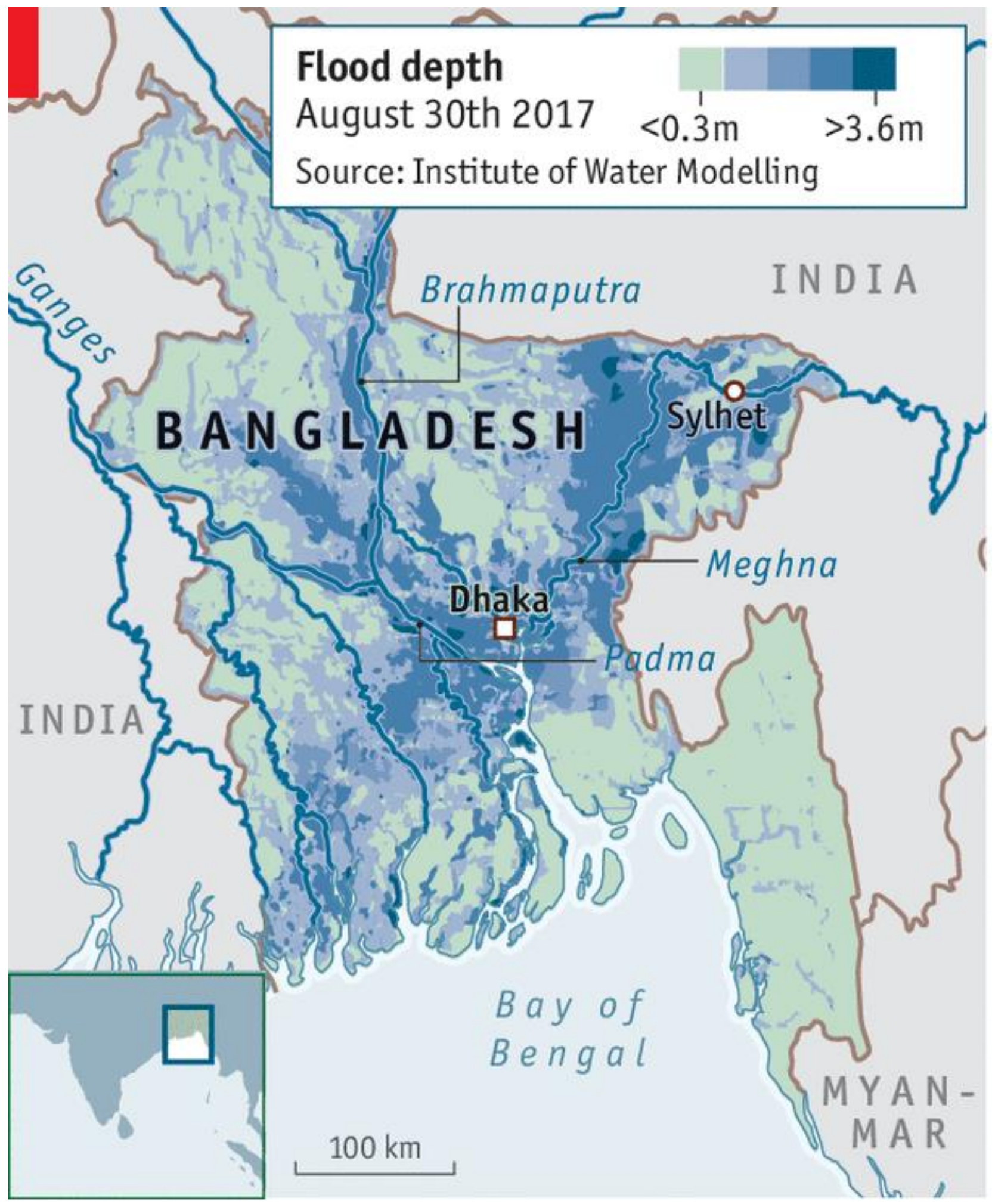

Economist.com

Figure 5. Map showing the inundation area of Bangladesh (source: Do What Season Occur Floods, 2019) 


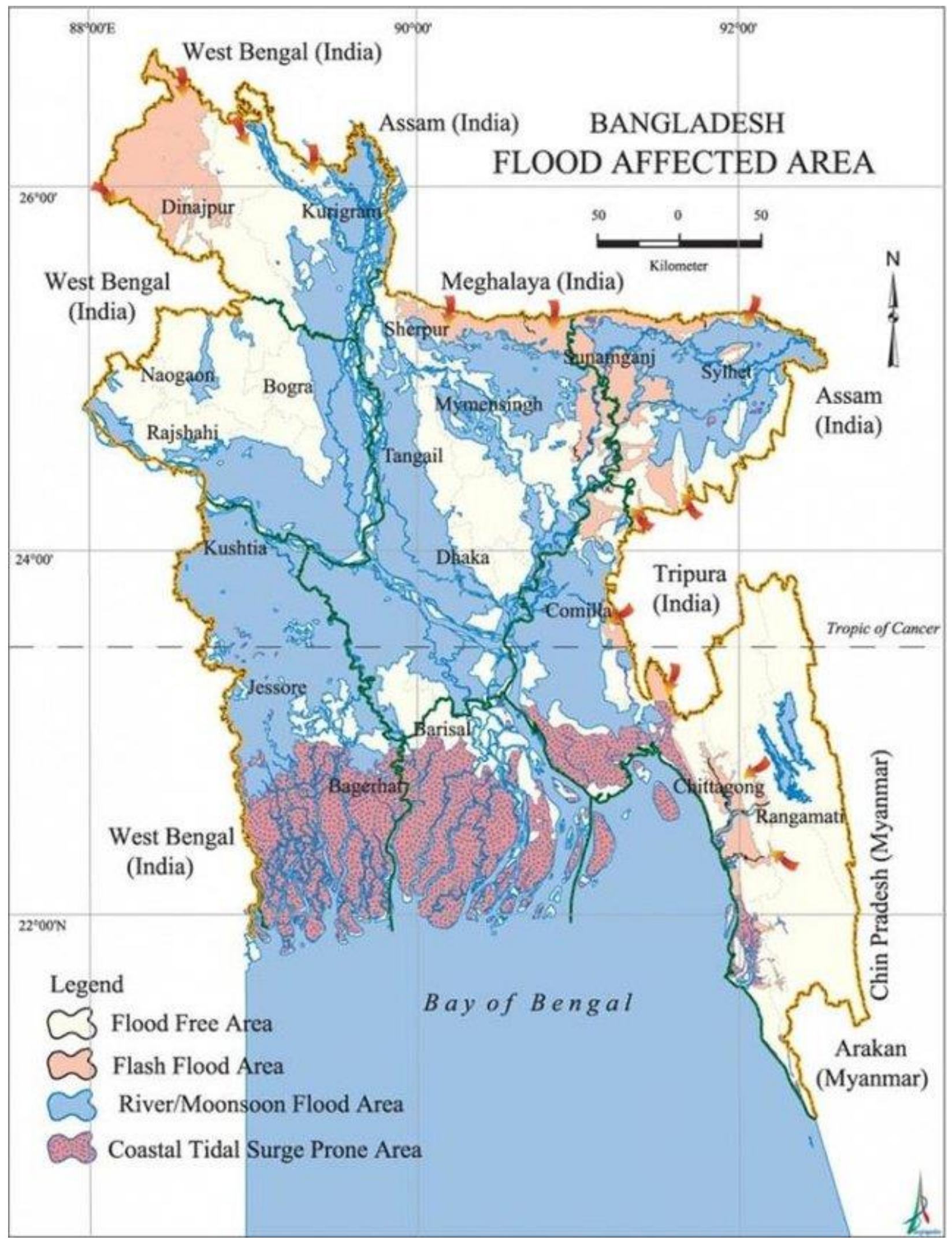

Figure 6. Map showing the division of area due to different types of flood (Bairagi et al. 2018) 


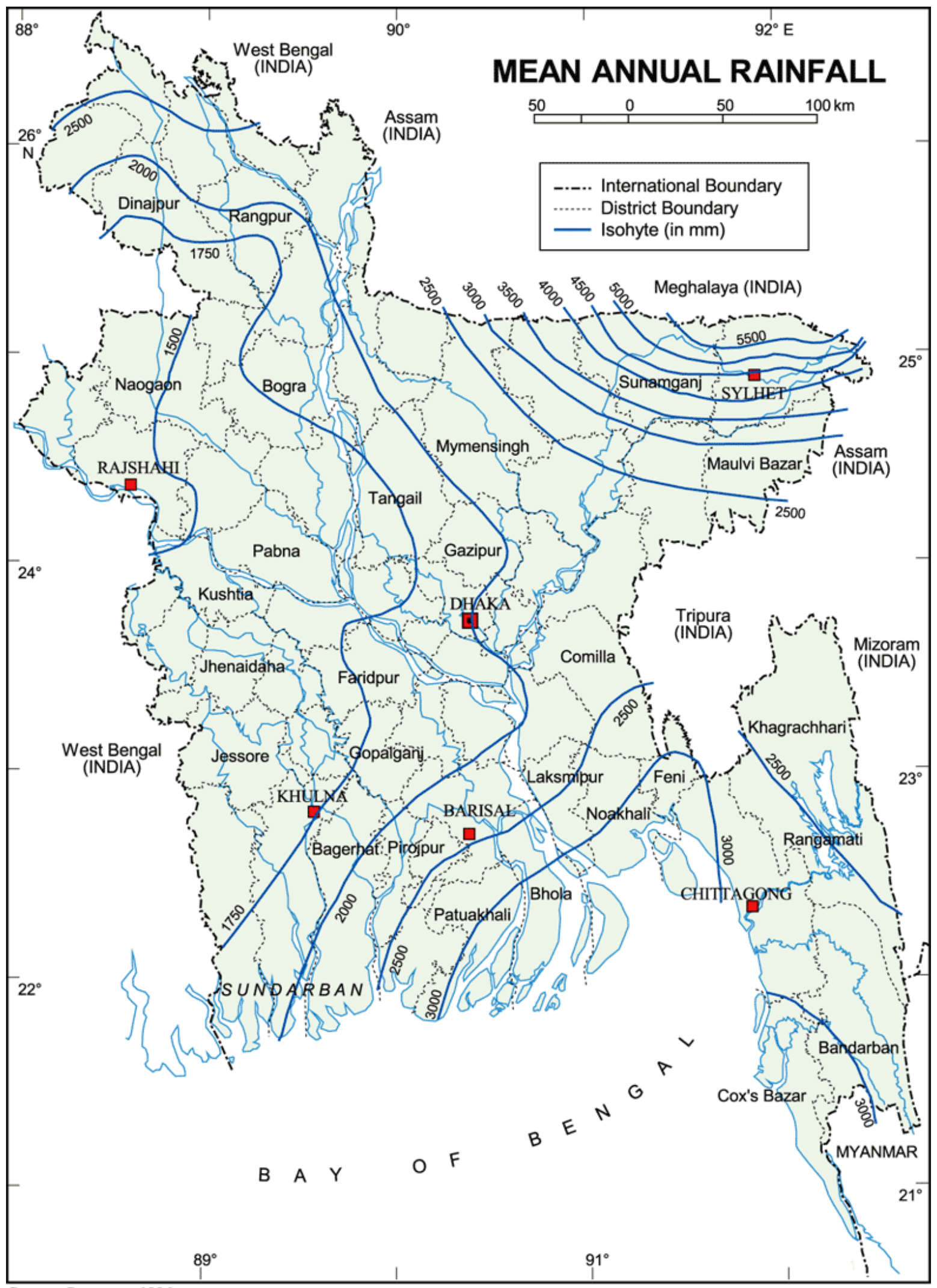

Source: Brammer, 1996

Figure 7. Map showing Mean Annual rainfall of Bangladesh (Hasan et al. 2014) 


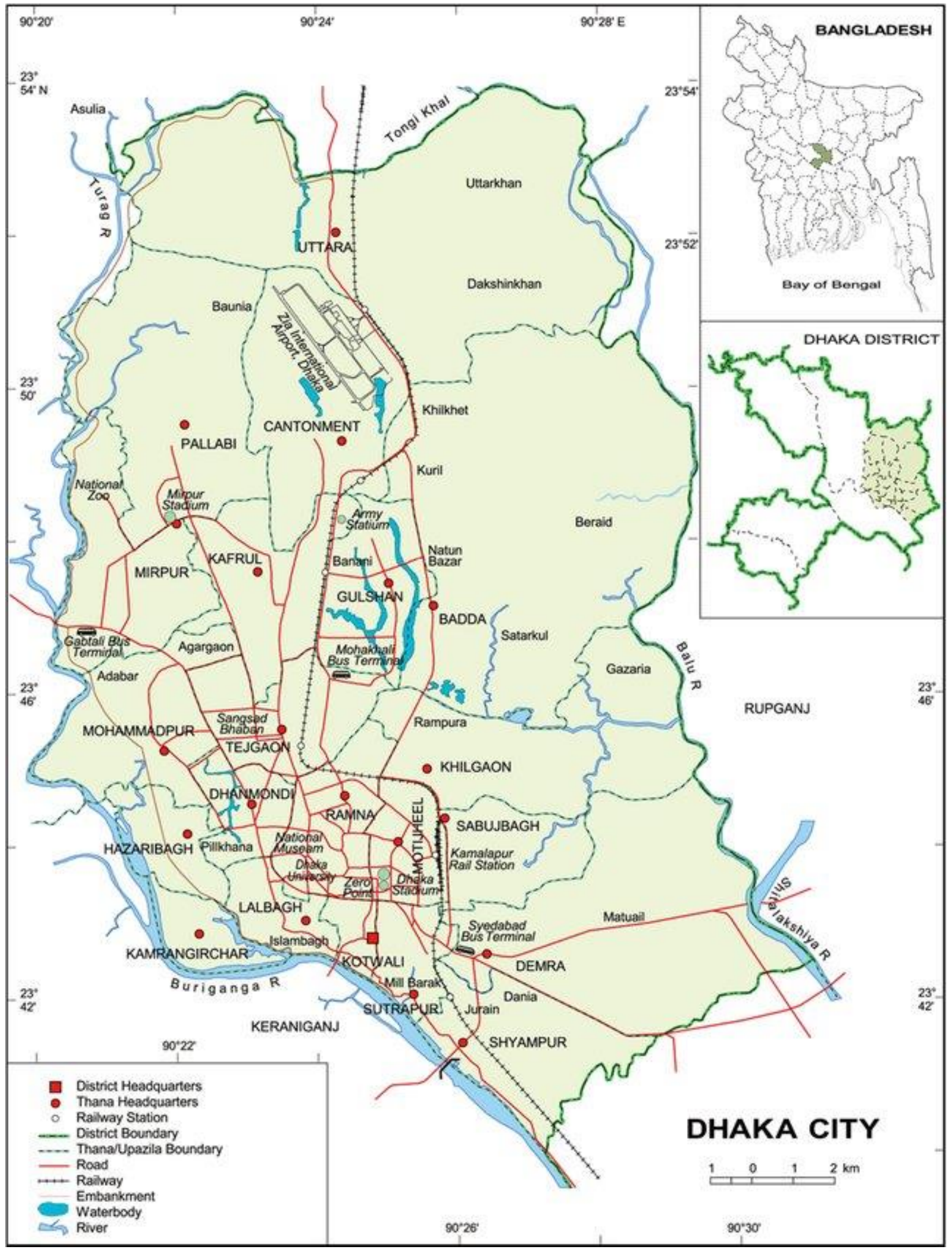

Figure 8. Map showing the Dhaka City area (Ahmed et al. 2014) 
The study area Dhaka is located between longitude $90^{\circ} 20^{\prime} \mathrm{E} \&$ \& $90^{\circ} 30^{\prime}$ and Latitude $23^{\circ} 40^{\prime} \mathrm{N} \&$ $23^{\circ} 55^{\prime} \mathrm{N}$. It is one of the fastest growing and densely populated cities of the world. Dhaka has an area of 306.38 square kilometers. In present, the population is 20,283 million and the density is 23,234 people per square kilometer. In the past, this city was regarded as the Venice of East (Mahmud et al. 2011), but now it is suffering from many environmental problems like; flooding, waterlogging, air pollution etc.

A few decades ago, Dhaka has many low lands, channels and khals which work as the primary drainage system for the whole city and carry the water towards the periphery rivers. There are three rivers surrounded the Dhaka city. The river Buriganga lies at south, at east there is river Balu and at north-west, there is Turag River (Mahmud et al. 2011). So, the city grew alongside its rivers and waterways (my paper). As a result, the city got its water network of natural canals which served as the means of drainage of the rain runoff and water (Figure 13).

Over the years the city grew in every direction. As a result, the landscape of this city is changing continuously (Sultana et al. 2009) and shrinkage this natural drainage and wetlands. It is caused mainly for unplanned urbanization, encroachment, lack of co-ordinance between government agencies, lack of maintenance and lack of implementation of relevant laws (Mahmud et al. 2011). As, a result, during monsoon, city dwellers suffers from waterlogging in many areas (Figure 9, $10,11,12)$ while doing their regular works.

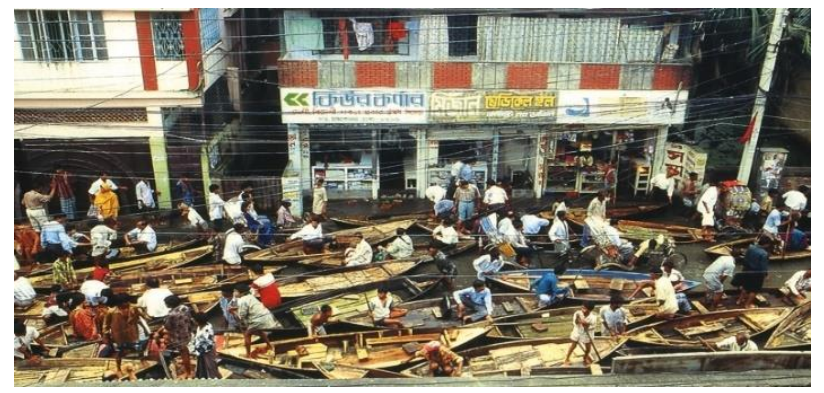

Fig: 9. Dhaka during 1998 flood, (Source: M. A. Taher, Waterlogging in Dhaka 2015)

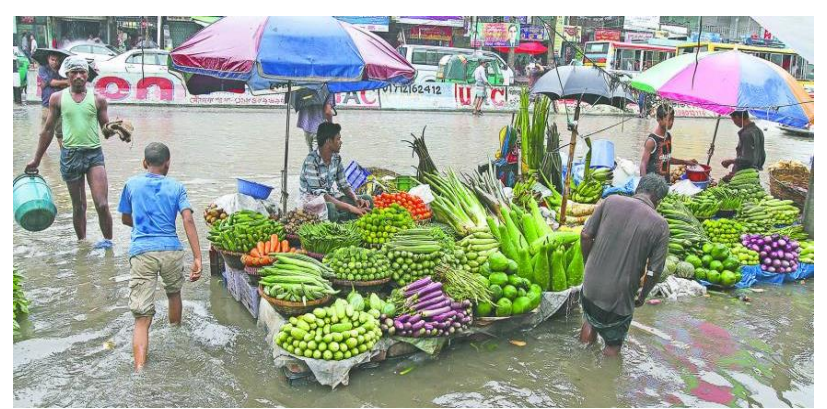

Fig: 11 Dhaka during 1998 flood (Source: M. A. Taher, Waterlogging in Dhaka 2015)

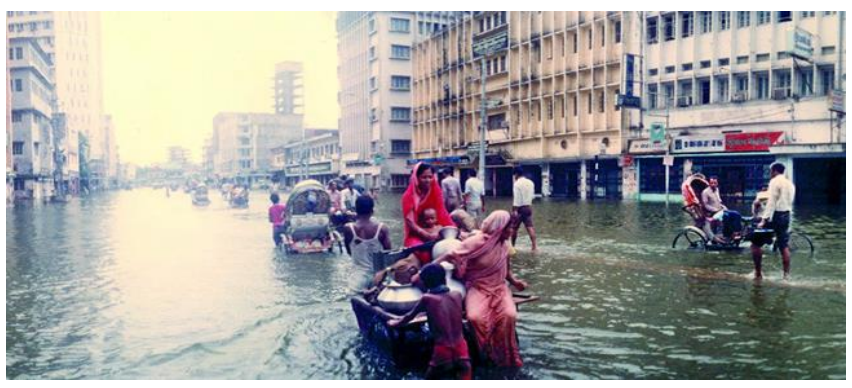

Fig: 10. Waterlogging: (Source: M. A. Taher, Waterlogging in Dhaka 2015)

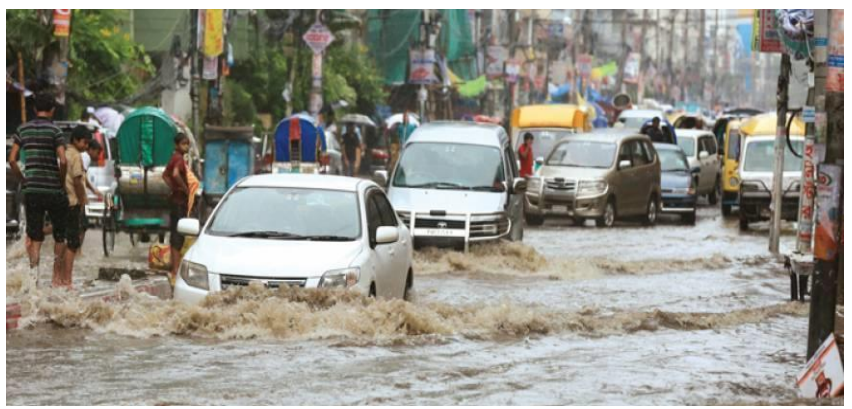

Fig: 12. Street conditions of Dhaka city during waterlogging (source: Ittefaq, 2015) 
Specially, to go from one place to another and to maintain their daily routine work. This brings traffic congestion which causes Tk 195,550 million loss per year. Sometimes, people find their own innovative way to solve the problem as a temporary basis or accepted this situation as their fate. As the climate is changing, so the scenario is worsening every year. Immediate step should be taken from the government level to mitigate the problem.

Waterlogging is identified as a major problem for the city in recent years in a report on the Strategic Environment Assessment of Dhaka (Mahmud et al. 2011). Under the Köppen climate classification, Dhaka has a tropical wet and dry climate (Datta and Mandal 2017). The annual average rainfall of $1,854 \mathrm{~mm}$ (73.0 in). Nearly $80 \%$ of the annual rainfall occurs during the monsoon season which lasts from May until the end of September (Datta and Mandal 2017). The number of annual rainy days of Dhaka City varies from 95 to 144 days (Ahammed et al. 2014, Datta and Mandal 2017). Rainfall is increasing at a rate of $55.90 \mathrm{~mm} / \mathrm{year}$. So, day by day the water logging problem becomes worse.

The purpose of this study is to develop a strategic process to reintroduce a buried waterway as a solution for present waterlogging for an area of Dhaka metropolitan city. To do this, a study will be required to find out the lost connections or buried waterways. Then, a specific place will be determined to carry out the study.

\subsection{Statement of problems}

The growth of urban infrastructures has been taking place in an unplanned way; as a result, it destroyed natural drainage systems, fill-up the water-bodies, which weakens the natural sewerage system and create waterlog during the rainy season for every year in various parts of the city. So, the study is for finding a possible solution due to the present waterlogging.

\subsection{Objectives}

- This study aims to develop a process to reintroduce a lost waterway as a possible solution for water logging in an area of Dhaka City.

- The most positive aspect of this proposal is to protect the water bodies.

- Unless existing wetlands and water bodies are protected, the drainage system of Dhaka will collapse and many of its areas will be inundated. If the method is worked then, it will be a key factor to make other dead water lines alive for Dhaka City.

\subsection{Research Question}

\section{Main question:}

How introducing a lost waterway can mitigate inundation rate for an area of a metropolitan city?

\section{Sub-question:}

How converting a vehicular road into a waterway can mitigate the water logging problem for that area during rainy season? 


\subsection{Methodology}

This is mixed method-based research. Figure 13 shows the steps in the diagram.

The process is structured in 6 ways (Figure 13).

a. Analyze the changes of waterways and wetlands to identify the lost waterways from taking evidence of historical maps, documents, Google earth pro images and using arch map tools.

b. Do a regional level inventory and analysis with documents, hydrologic analysis with arch map tools and studying about future urban planning proposal to identify the study area for the research work.

c. Find out some case studies to establish the arguments.

d. Find out the catchment area through hydrologic analysis in ArcGIS with arch map tools.

e. Calculate the volume of surface runoff during the rainy season for the study area.

f. Provide design guidelines according to the site analysis and calculation.

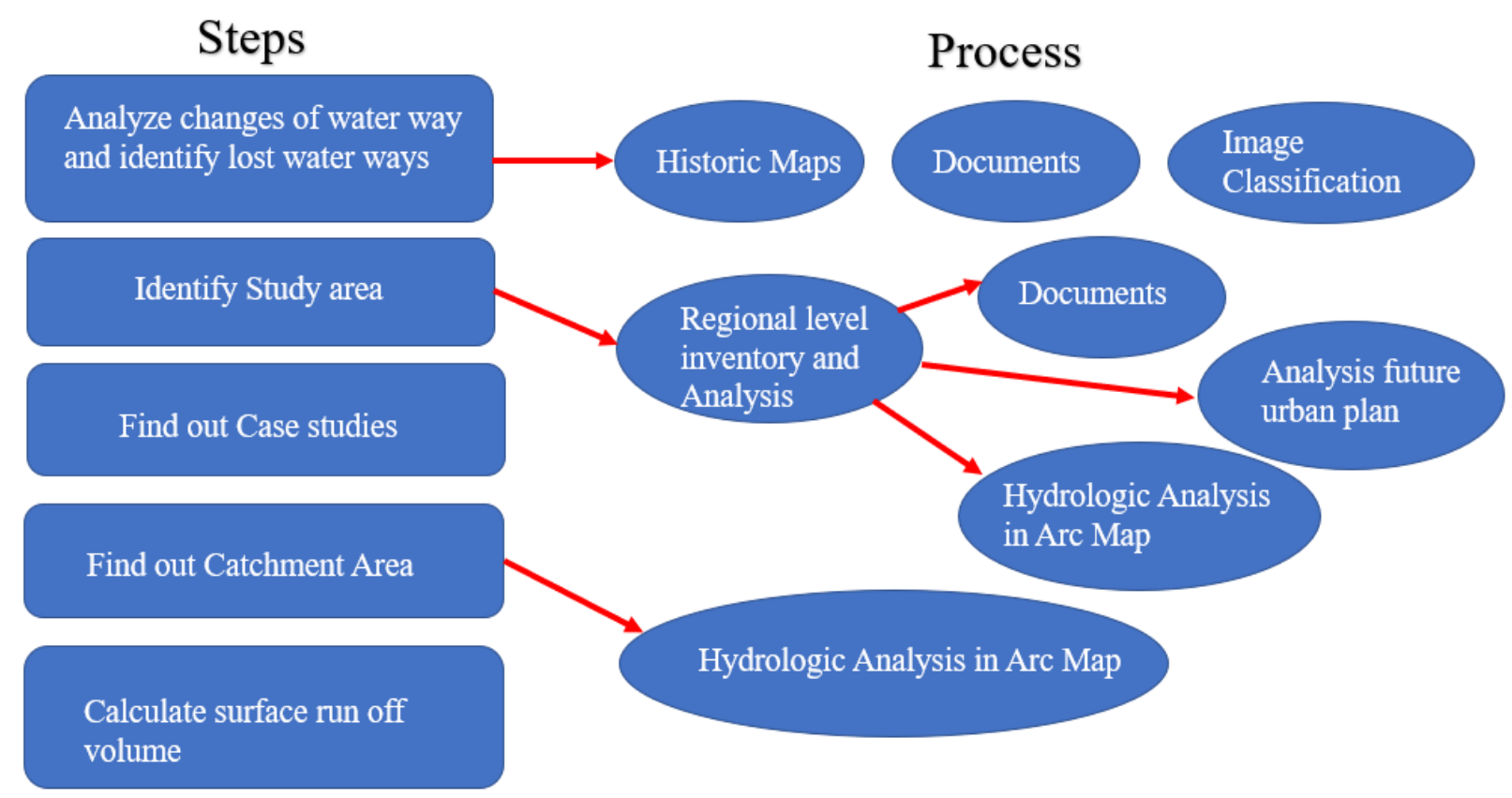

Provide design guidelines

Figure: 13. Diagram of Methodology. 


\subsection{Literature Review}

\section{A. Strategic Process}

Strategies have many definitions, but they usually involve setting goals, determining the action to be achieved and mobilizing resources for accomplishing those goals. The strategy describes how to achieve the goal through means, resources, and methods. Strategies can be planned, targeted; or may be viewed as patterns of action. It includes the process of formulation and implementation and helps to coordinate both processes. However, strategic planning is inherently analytical; this means that the strategy structure itself includes the integration of the point and connects with a combination of strategies. Therefore, strategic planning is done around strategy development activities (Oliver, C. 1991).

Strategic planning processes are basically a list of steps administrators should follow to achieve and implement strategies within the company. There are several key elements that constitute the strategic planning process, such as general stages of strategic analysis and strategy formulation, as well as implementation and monitoring. The strategic planning process requires a lot of patience and is a difficult task, but this process brings very useful results. In the first phase, preparation for the rest of the strategic planning process is prepared. Achieving the goal requires first a clear vision. First short- and long-term goals should be defined. Then determine the steps you need to take to achieve these goals. When identifying strategic stance, it should be remembered that the goal is real and must be measured. In order to help step by step, mission statements, corporate values, and work culture should be reviewed.

\section{B. Waterlogging in urban area}

Urban sprawl damages the water system and causes major changes in the hydrological system. In general, the change in flow hydrology and morphology is due to the imbalance of channels caused by increased sediment and water drainage. Urbanization creates an unsecured surface in the basin. Land surface penetration is declining.

Disasters such as floods have changed the size in urban areas. Urban flooding in cities is primarily a form of flash flood and the city's water logging occurs through high intensity, short spells of rain. However, without a proper drainage system, rainfall can cause waterlogging and related problems than semi-urban or rural area.

As most of the urban areas are formed and the remaining unpaved or unspecified parts of the city are hardened, so, the land's permeability is declining dramatically. Due to the increase in precipitation and increasing population and asset concentration due to resource allocation, the extent of these disasters has increased over time in urban areas. Understanding the cause of waterlogging, vulnerability and exposure is essential to quantifying current and potential risks.

\section{Water sensitive urban design}

Water sensitive urban design is a method of land planning and engineering that incorporates the city's watercourse, groundwater, sewage treatment, and wastewater management to reduce its 
impact on the environment. WSUD is a term used in the Middle East and Australia, which are similar with low impact developmental conditions; whereas America uses it as a word for sustainable drainage systems, and layoffs.

In the future, comprehensive urban water management will rebuild the relationship between cities and other resources. It will require an expanded range of urban water management models and increased environmental monitoring and information through factual foundations. In addition, it requires a framework for negotiation involving all stakeholders and emphasizes the importance of progressive but comprehensive institutional forms and clarity in local, regional and domestic decision-making processes.

\section{Understanding the drainage system}

The area upon where water falls and travels through towards an outlet and make a network is known as the drainage system. The flow of water through a framework is normally known as the hydrologic cycle. Hydrologic cycle incorporates precipitation, evapotranspiration, and groundwater flow. A drainage basin (Figure 14) is an area that drains water to a common outlet. Other common terms for a drainage basin are watershed, basin, catchment, or contributing area. This area has an outlet or pour point which is the lowest point for that area and water of total area flows out from the pour point. The boundary between two basins is named as watershed boundary. The hydrology tools in ArcMap focus on the movement of water across the surface.

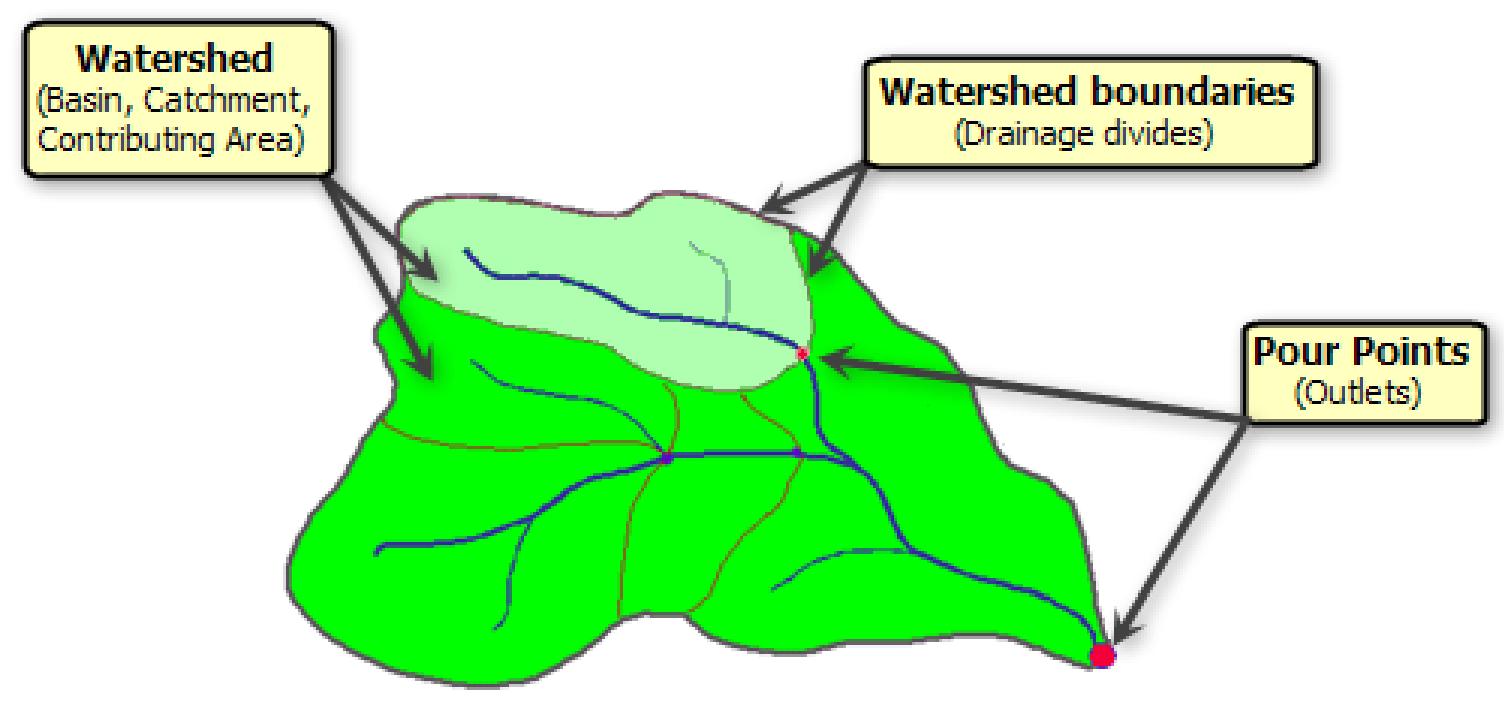

Figure 14. Components of drainage basin (source: ArcGIS online resource)

\section{E. Watershed/Basin}

A watershed or basin is a land that flows to the same endpoint. Watershed boundaries are defined by the terrain of the land. The watershed or basin boundary identify all areas that contribute to the flow of water (Figure 15).

The highest feature of the land, such as ridgetop, forms a watershed or basin around the drainage zone and flows to the lowest point. All water in the area, including lakes, rivers and subsurface water flows is part of the classification of the basin. The water basin is sometimes replaced by 
drainage and water supply. The ridges and troughs separating the two bodies are called drainage channels. The basin is composed of surface water, lakes, reservoirs, and wetlands and includes all the potential groundwater. Large watersheds include many small ponds. Watershed can be delineated from a DEM by using flow direction and watershed tool of ArcMap.

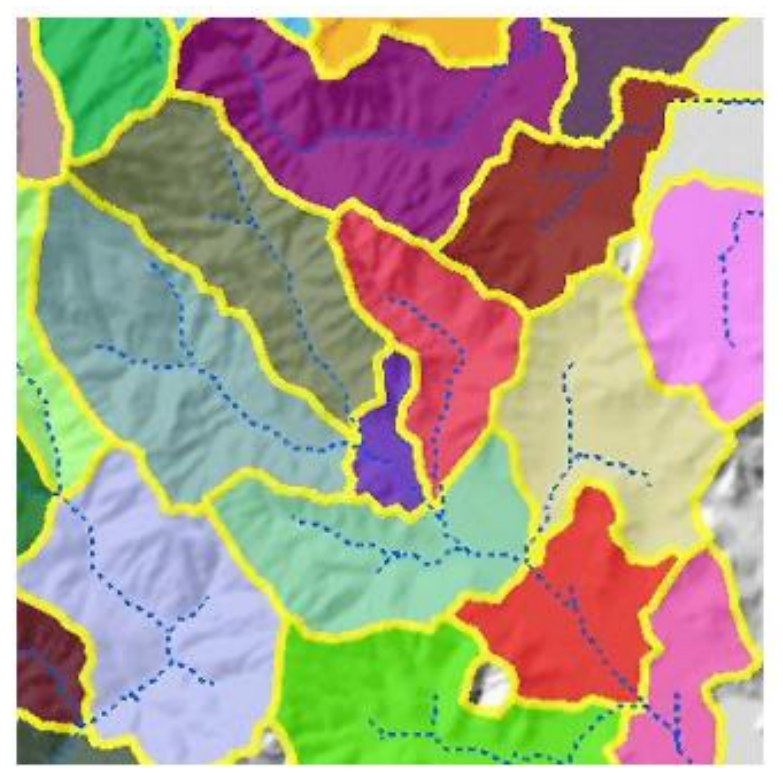

Figure 15: Delineated watershed (source: ArcGIS online resource)

\section{F. Flow accumulation}

Figure 14 shows the network of water flow. Flow accumulation is to calculate the cells that drain into each cell. As an example; Figure 16 and 17 shows the numeric value of each cell. The value of very top left is zero (0) that means no other cell is going to that cell. The diagonal cell which has value of three (3) has three other cells which are drained into to that cell number three. The largest numerical value here is twenty-four (24), which has almost all other cells to drain into this cell and added up to make this cell. So, flow accumulation value can be specified, which means, it can be determined, which cell is designated for stream and which cell is classified for run off.

For example, here the cell value less than 10 can be designated as run off and the cell value which has more than 10 can be designated as stream. The National Elevation Datasets uses a value of 5000 cells or greater to determine stream location.

There is no set value to determine the location of stream. It depends on the project site; the resolution of the data to define any existing stream line. It is a trial and error thing to determine the cell value for stream location and runoff. Flow accumulation tool in hydrology toolset of ArcMap is used for this study. 


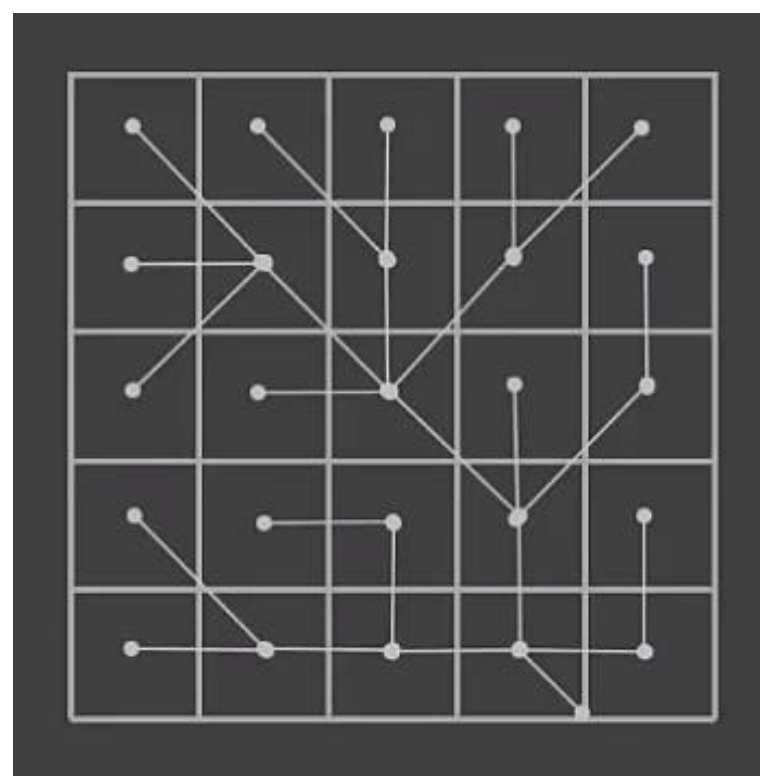

Figure.16 Water flow direction network

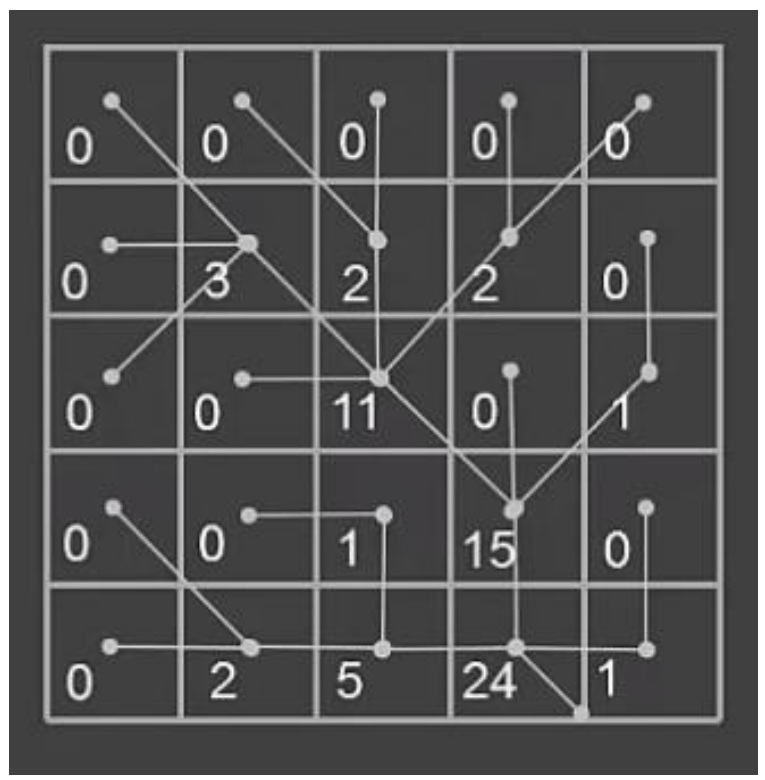

Figure.17 Showing numeric value of every cell

\section{G. Flow Direction}

Flow direction map is useful to know about the contribution of surface runoff to flooding. Hydrologist also uses it for a lot more. The flow direction calculates the rate of movement in a given area using slope from neighboring cells (Figure 18). This method (Figure 20) uses the slope of a column to determine where water flows through that column. In other words, the slope of a column is determined by its velocity and volume. It can be used to calculate the amount of water flowing through that column. Flow direction calculates the speed and direction of water moving through a column.

DEM (digital elevation model) data is necessary to use the flow direction tool in ArcMap. Flow direction depends on the direction of the steepness of each cell. The height and slope are calculated among neighboring cells.

It is determined, water can flow to one or more of its eight adjacent cells ("Flow Direction Calculates Water Direction Using Slope”, 2018). Pour-point model is used to show the water travel direction ("Flow Direction Calculates Water Direction Using Slope",2018) (Figure 19).

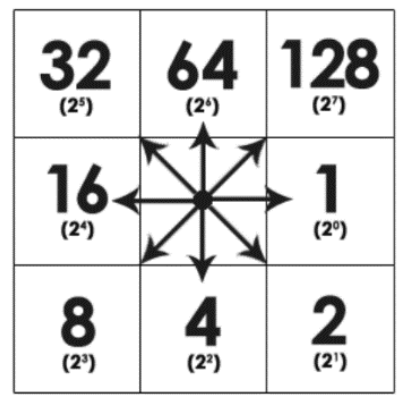

Figure 18: Flow Direction: Eight Direction Pour-Point Model (source: Flow Direction Calculates Water Direction Using Slope, 2018) 
For example:

Every number defines the direction of water flows. When water flows west, it has a value of 16. There is the eight-direction pour point model to describe the 8 adjacent directions. The resulting values of flow direction algorithm range from 1, 2, 4, 8, 16, 32, 64 and 128 ("Flow Direction Calculates Water Direction Using Slope", 2018).

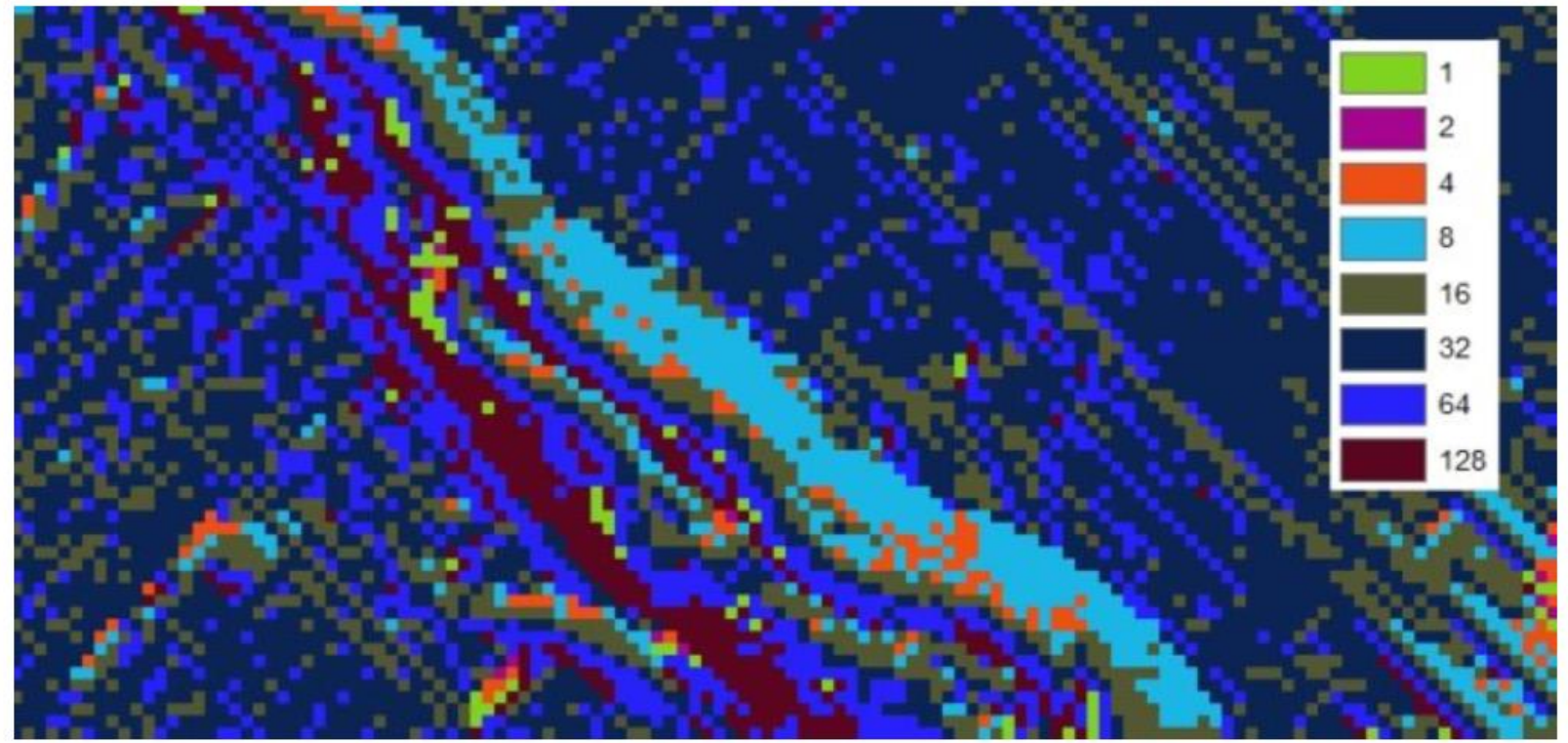

Figure 19: Flow Direction Map (source: Flow Direction Calculates Water Direction Using Slope, 2018)

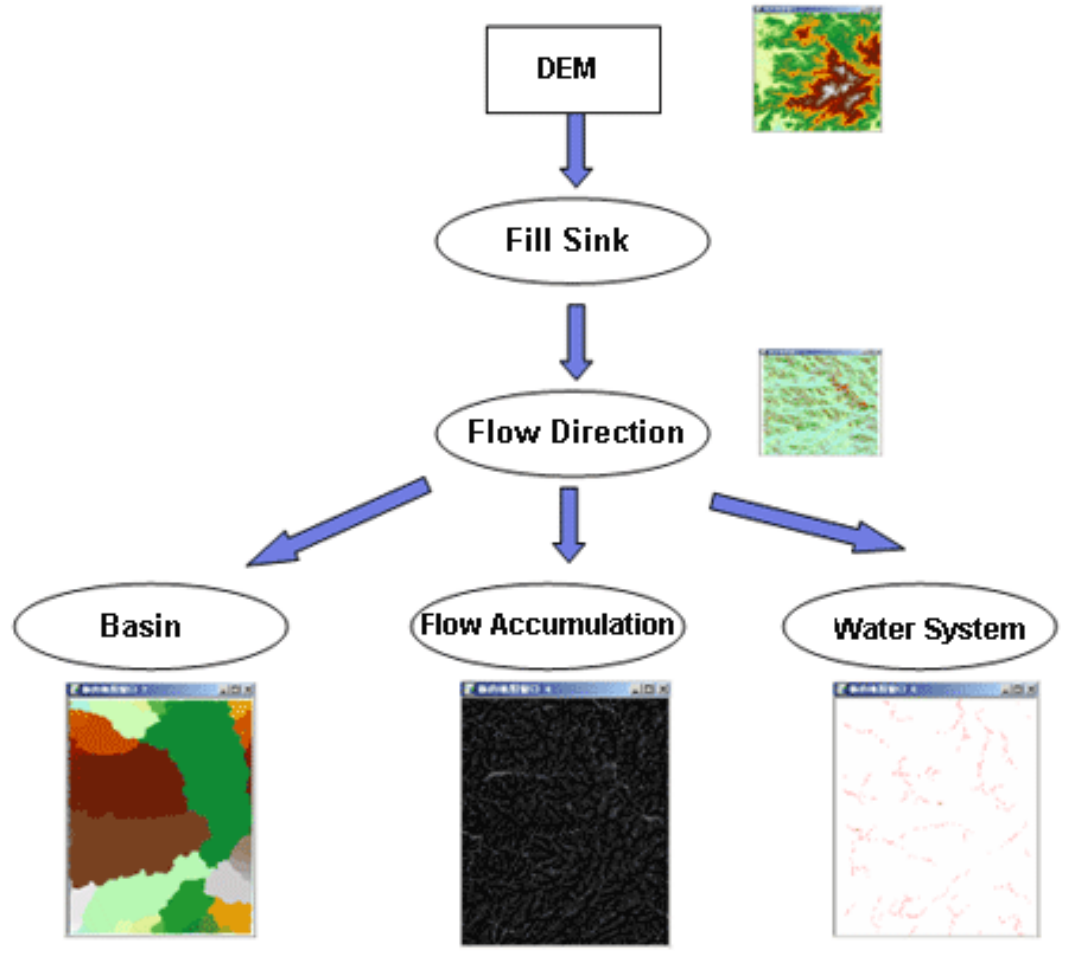

Figure 20: Steps of using Hydrology tools in Arc Map (source: ArcGIS online resource) 


\section{CHAPTER Z. INVENTORY AND ANALYSIS AT METROPLLITAN SCALE}

\subsection{Geomorphology}

The surface of Dhaka is mostly flat and a few meters higher than the surrounding area. The metropolis area of Dhaka is sited at the Pleistocene Madhupur Tract, an elevated terrace (Figure 21 and 22), which is higher than the surrounding flood plain (Hoque., et.al. 2017). A larger portion of the city surface has low lands and depressions. Where the elevation of city surface ranges from $1.5 \mathrm{~m}$ to $15 \mathrm{~m}$ above the PWD (Public Works Department) datum ( $+/-1 \mathrm{~m}$ to mean sea level), the elevation of low lands, abandoned channels and depressions varies from $1.5 \mathrm{~m}$ to $3.5 \mathrm{~m}$ above PWD datum (Hoque., et.al. 2017). The stormwater runs through these low land areas and flows toward khals and local rivers to discharge surface runoff. So, when these areas are filling up due to urbanization purpose, it becomes vulnerable to flood during the rainy season.

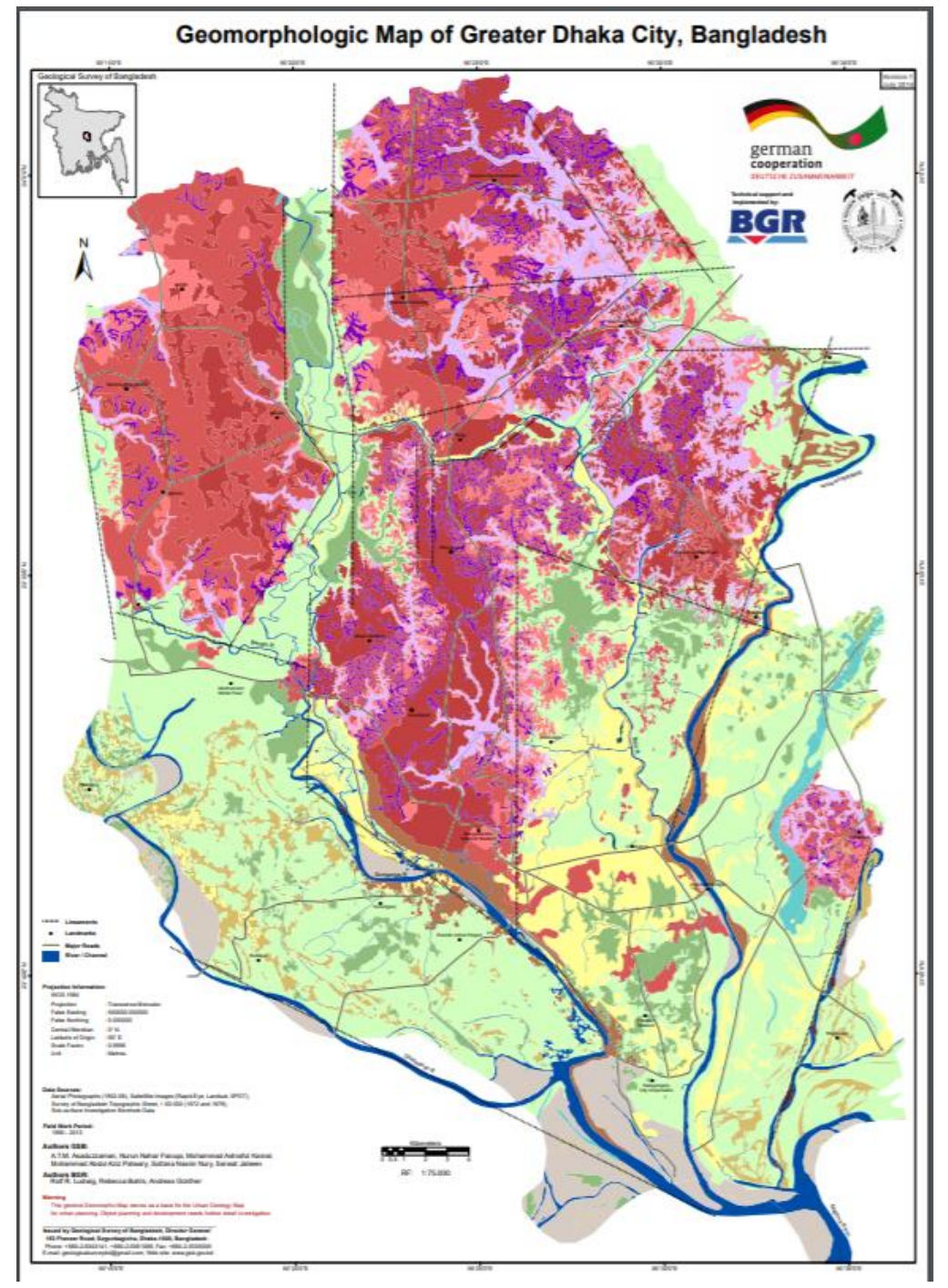

Figure 21: Geomorphological Map of Dhaka (source: Geological Survey of Bangladesh, 2014) 


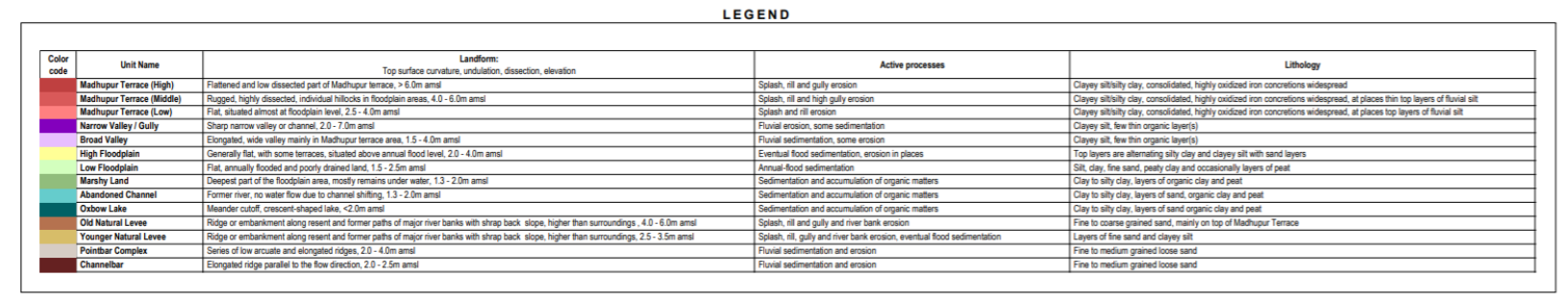

Figure 22: Legends of Geomorphological map of Dhaka (source: Geological Survey of Bangladesh, 2014)

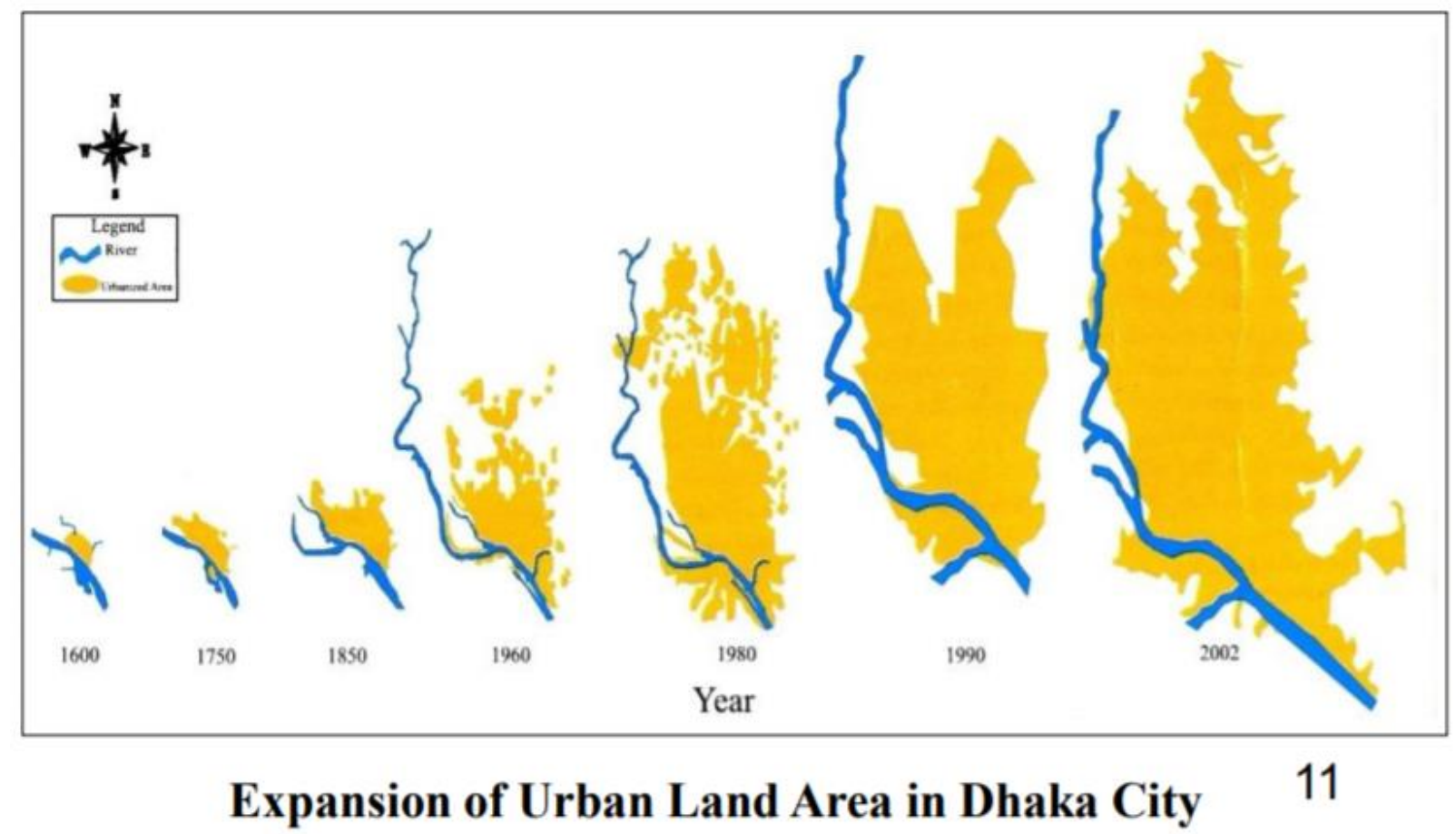

Source: DCC profile

Figure 23: Growth pattern of Dhaka city (Ahmed et al. 2014)

The growth pattern (Figure 23) shows the direction of development for Dhaka city. It almost covers the all low lands at the north and east portion and fills all wetlands.

\subsection{Weather}

Dhaka experiences a hot, wet and humid tropical climate. Under the Köppen climate classification, Dhaka has a tropical wet and dry climate (Datta and Mandal, 2017). The city has a distinct monsoonal season, with an annual average temperature of $25^{\circ} \mathrm{C}\left(77^{\circ} \mathrm{F}\right)$ and monthly means varying between $18{ }^{\circ} \mathrm{C}\left(64^{\circ} \mathrm{F}\right)$ in January and $29^{\circ} \mathrm{C}\left(84^{\circ} \mathrm{F}\right)$ in August (BBS, 2016). Nearly 80\% of the annual average rainfall of 1,854 $\mathrm{mm}$ (73.0 in) occurs during the monsoon season which lasts from May until the end of September. The number of annual rainy days of Dhaka City varies from 95 to 144 days (Ahammed et al. 2014). 


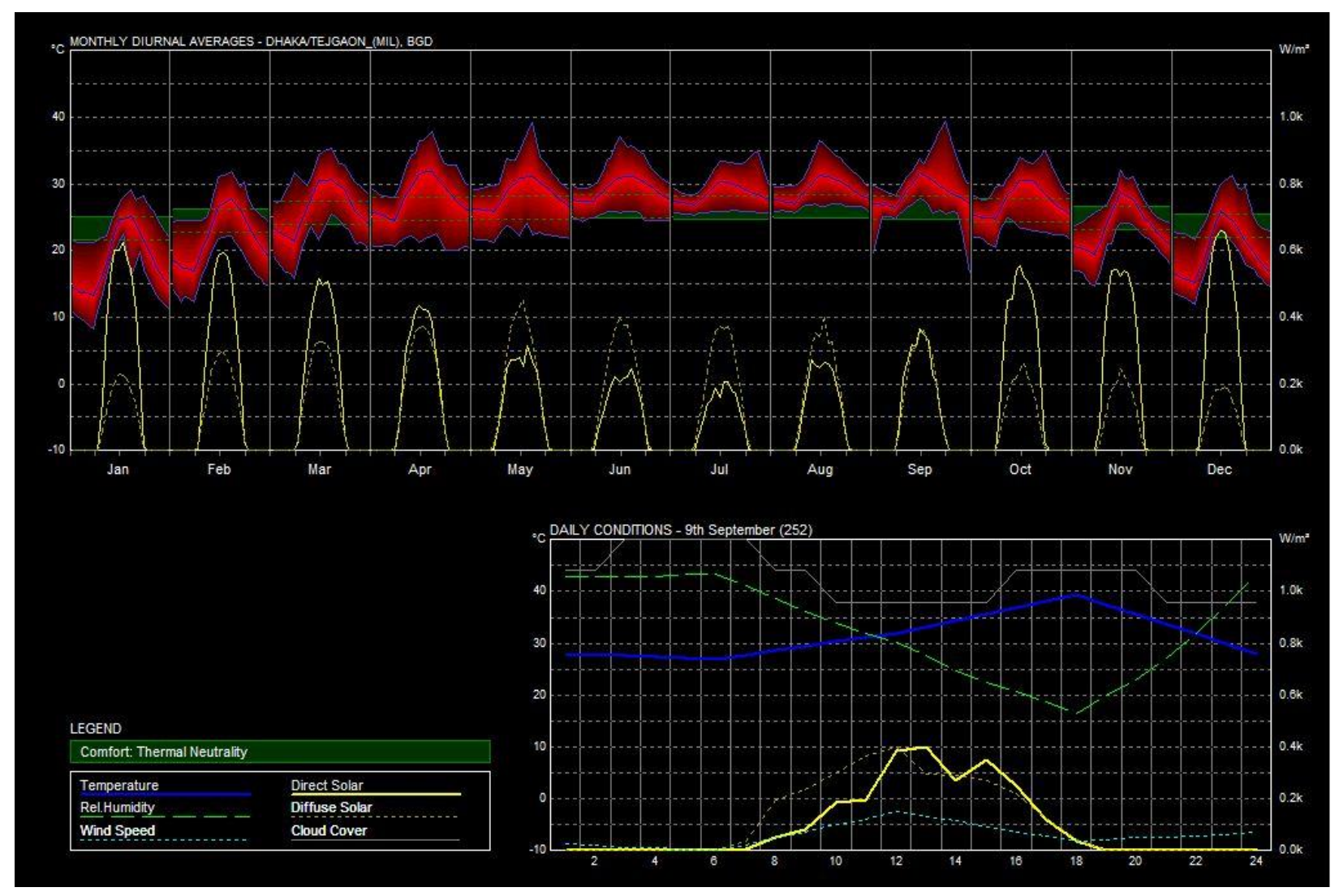

Figure 24: Monthly diurnal average

Figure 24 and 25 shows that the temperature distribution of Dhaka throughout the year in relation to direct and diffuse solar radiation. It is observed here; the average temperature is mostly remaining out of the comfort zone. Only during the brief winter months, day time temperature

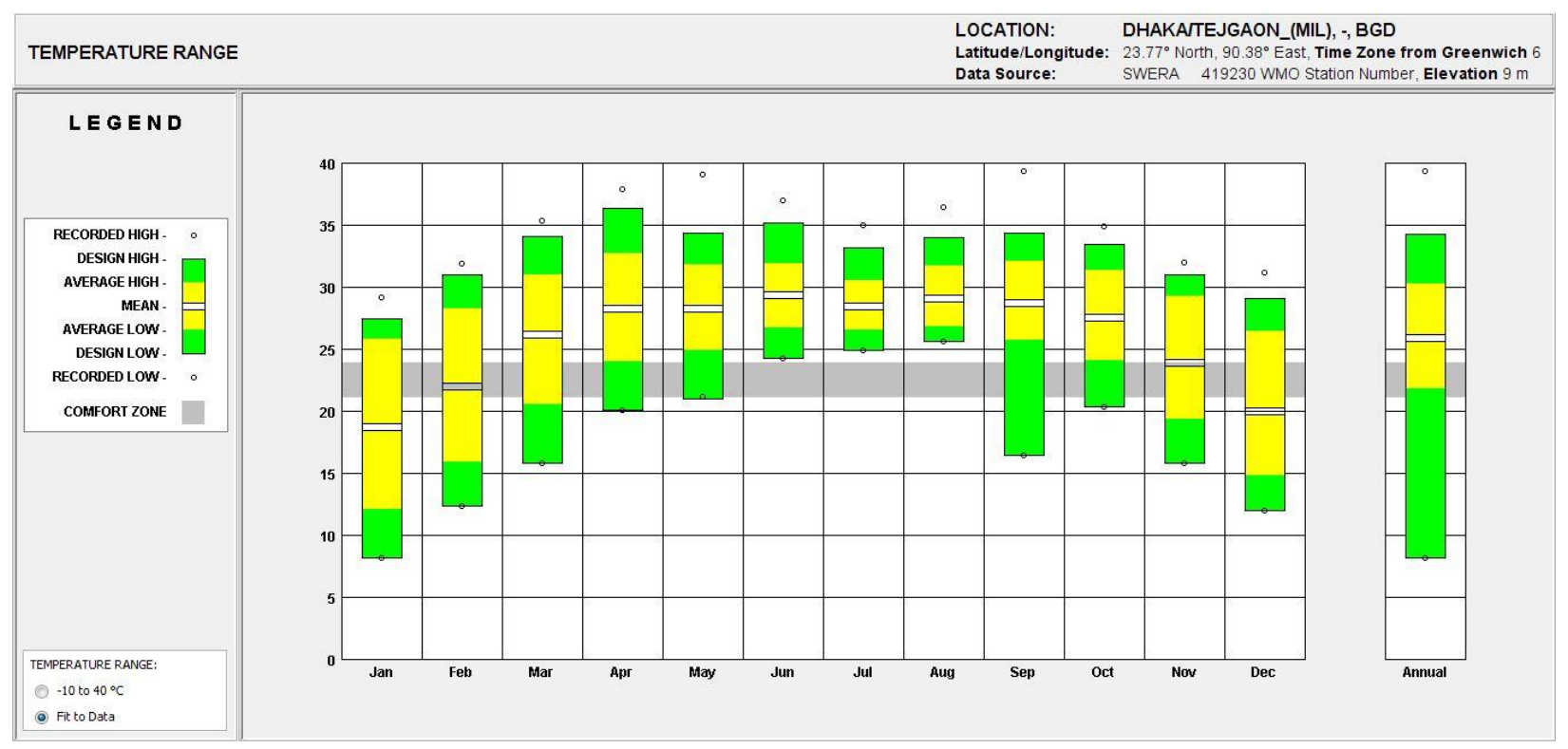

Figure 25: Temperature range chart 
remains within a comfort zone. Due to this reason, every kind of outdoor activity needs shaded space with either natural or manmade structure. From Figure 26 and 27, the relation between and dry bulb temperature and relative humidity is observed. The dry bulb temperature remains high throughout the year and reaches its peak point during 2:00 p.m.-3:00 p.m.

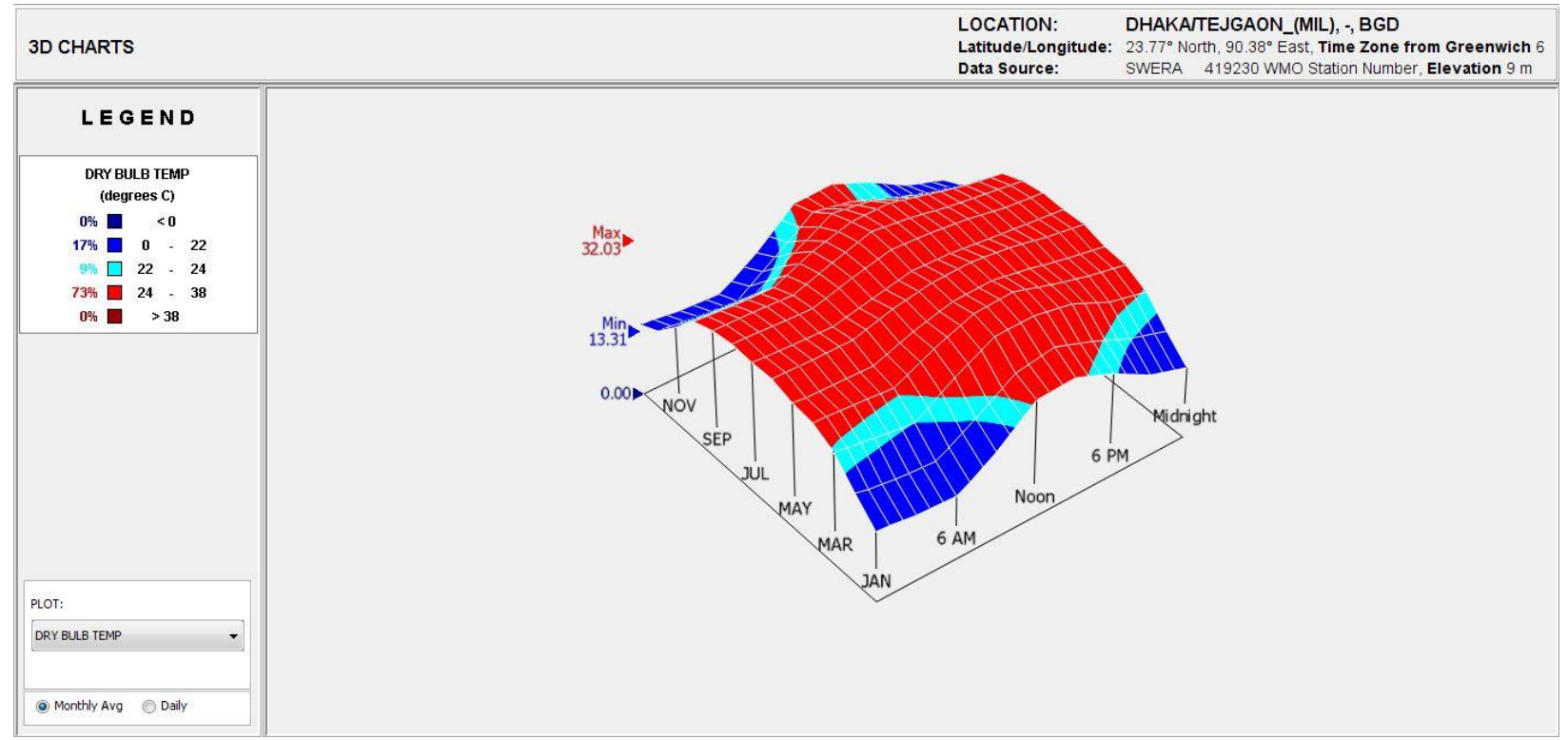

Figure 26: Dry bulb temperature graph

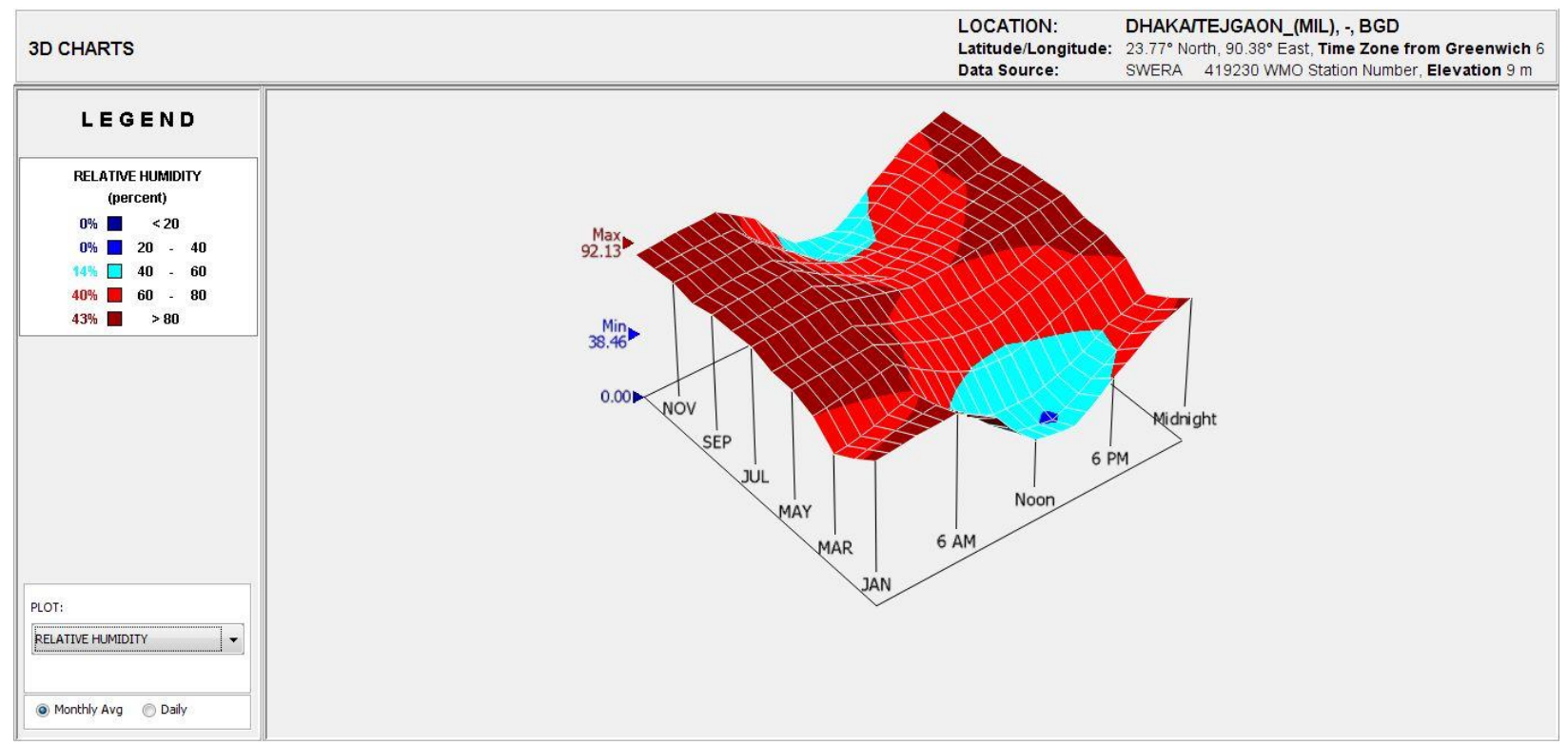

Figure 27: Relative humidity graph

The relative humidity also remains high around the year. This combination of high temperature and high humidity creates an uncomfortable situation in the absence of moving breeze. Therefore, priority should be given to maximize natural ventilation and minimize hard surface to avoid overheating. It is beneficial to have a water body or a flowing waterway near any kind of 
infrastructure as the water absorbs a large amount of radiant heat from its surrounding infrastructure and induce a cooler microclimate around its periphery.

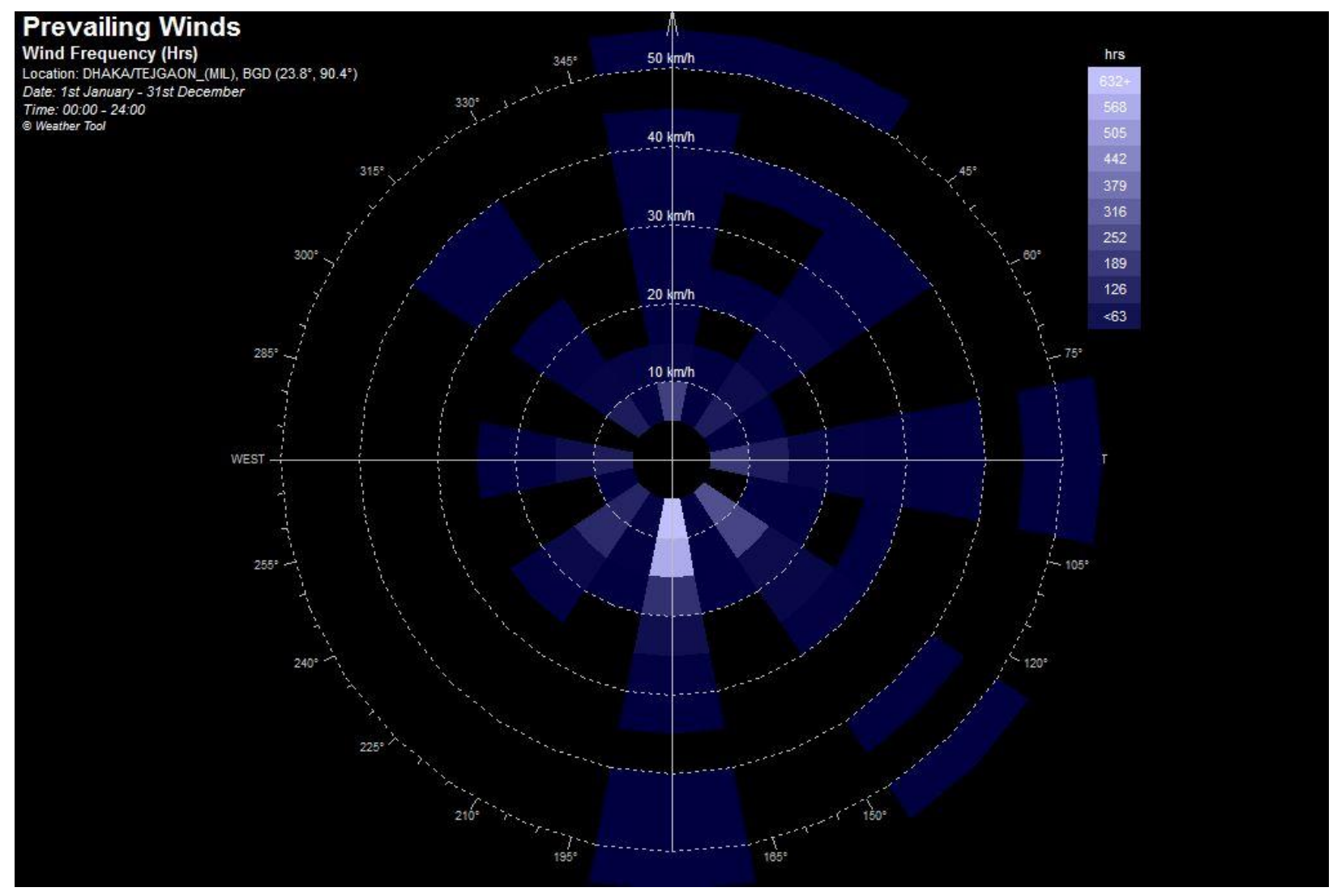

Figure 28: Wind velocity

Figure 28 shows the direction and velocity of the prevailing wind of Dhaka. It is observed here, the prevailing wind direction for Dhaka is south and south-east. During the hot and humid summertime, the gentle breeze comes from south and south-east can decrease the negative impact of overheating and exertion. Therefore, it is ideal to provide open corridor at the south or southeast side to invite the prevailing wind. On the other hand, the wind changes its direction to north or north-west during the winter season and brings dry and cold air. So, it is better to block the north west direction to prevent discomfort from wind chill.

The diagram of prevailing wind direction with average rainfall (Figure 29) shows that north breeze has less amount of rainfall, while the south breeze brings most of the rain. As a result, wind comes from the north is very dry and has less humidity than the winds from the south direction. Only the north-west wind causes the northwester storm which has very heavy rain and wind force during the beginning of summertime.

The other chart (Figure 29) shows the correlation between wind velocity and wind temperature. It is observed here the wind comes from south and south-west has the highest temperature while a wind from north and north-west brings the cooler effect during the winter season. The graph also 
suggests the temperature is gradually increased during day time from morning to noon. As a result, in afternoon south-west wind reaches the highest wind temperature during summer time.

So, to design purpose, it is suggested to provide a buffer zone to create wind barrier at the southwest direction in the summertime. For winter, as north and north-west wind has the lowest temperature, so to design purpose, this area should be covered to avoid discomfort due to cold.
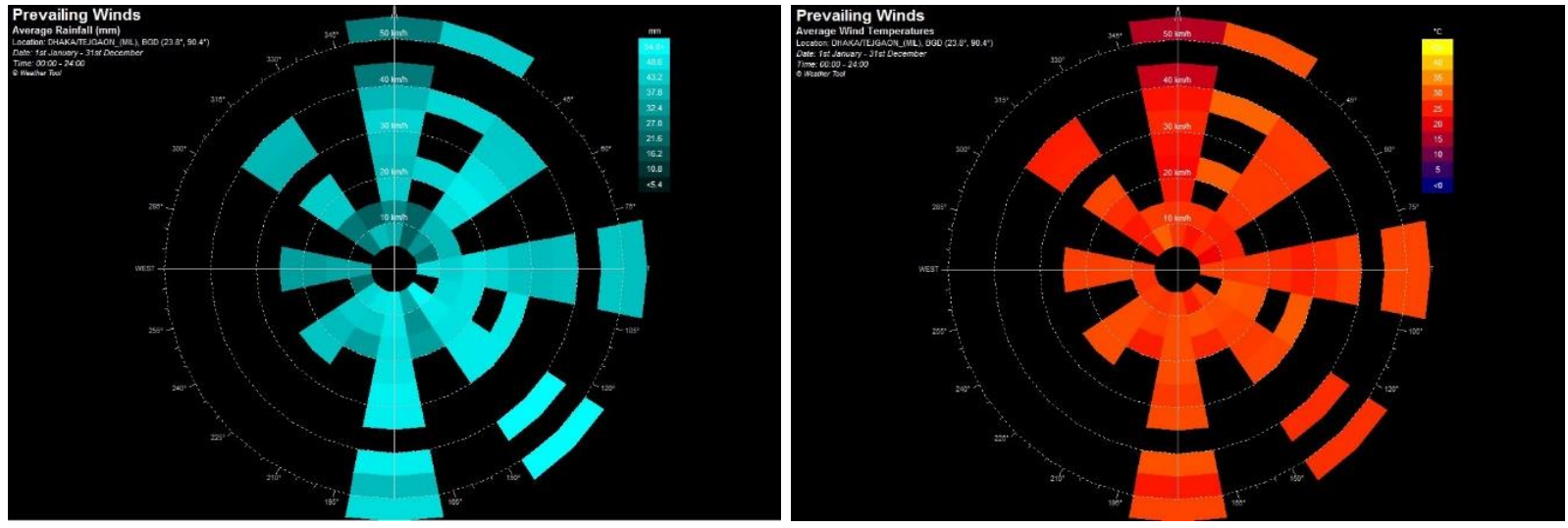

Figure 29: Prevailing wind in relation with Average rainfall and average wind temperature

Figure 30 shows the average daily rainfall scenario of Dhaka city. The average daily rainfall varies from $20 \mathrm{~mm}$ to $60 \mathrm{~mm}$ throughout the year. The driest time of the year is from November to February, where the rainfall range hardly goes beyond $30 \mathrm{~mm}$. From June to September, the rainfall intensity increases up to $60 \mathrm{~mm}$ and it is recognized as a wet period of a year.

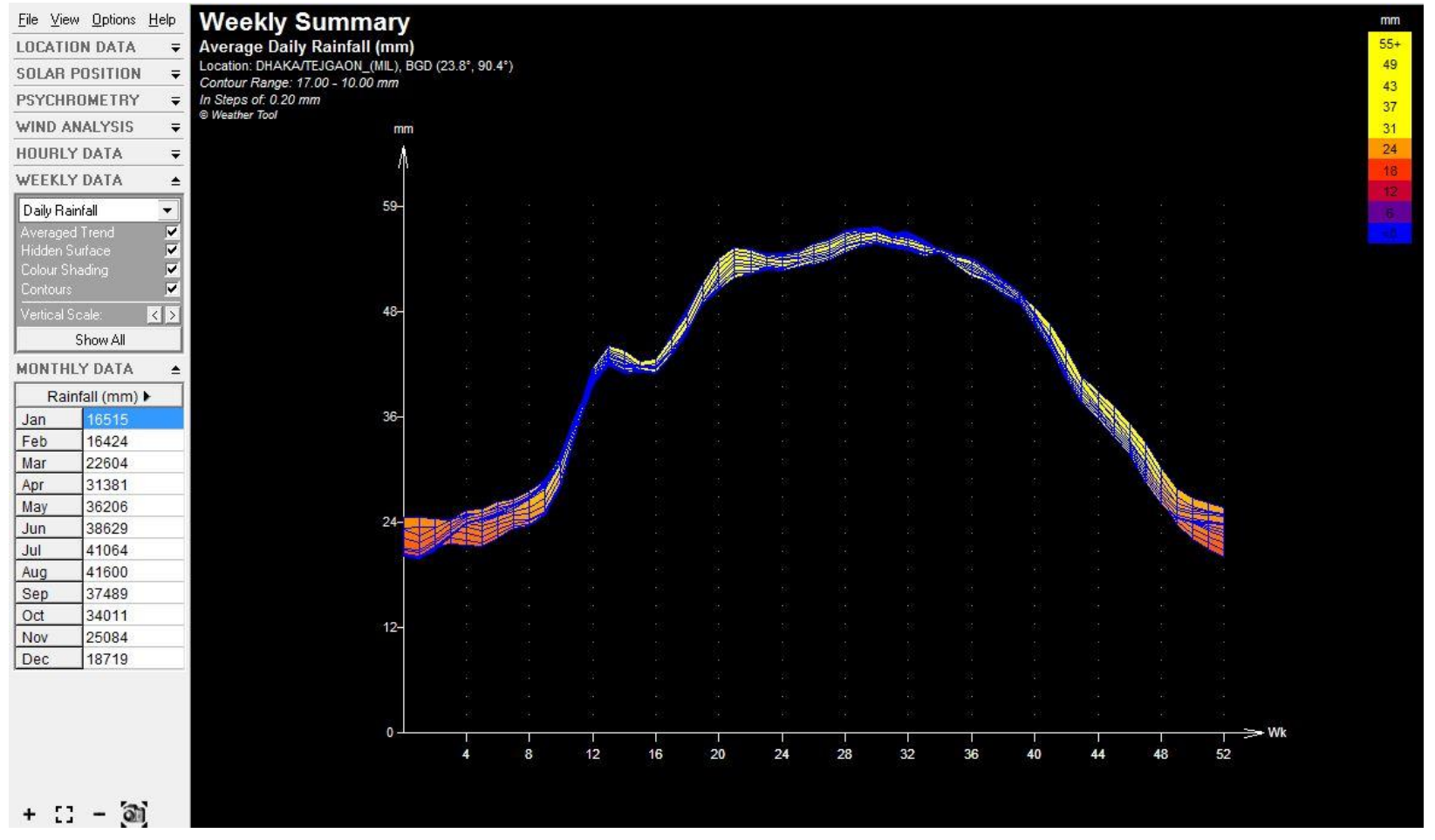

Figure 30: Average daily rainfall $(\mathrm{mm})$ 
During this time frame, heavy rainfall can occur every single day. Some study shows that the rainfall intensity can be high as much as $400 \mathrm{~mm}$ per day.

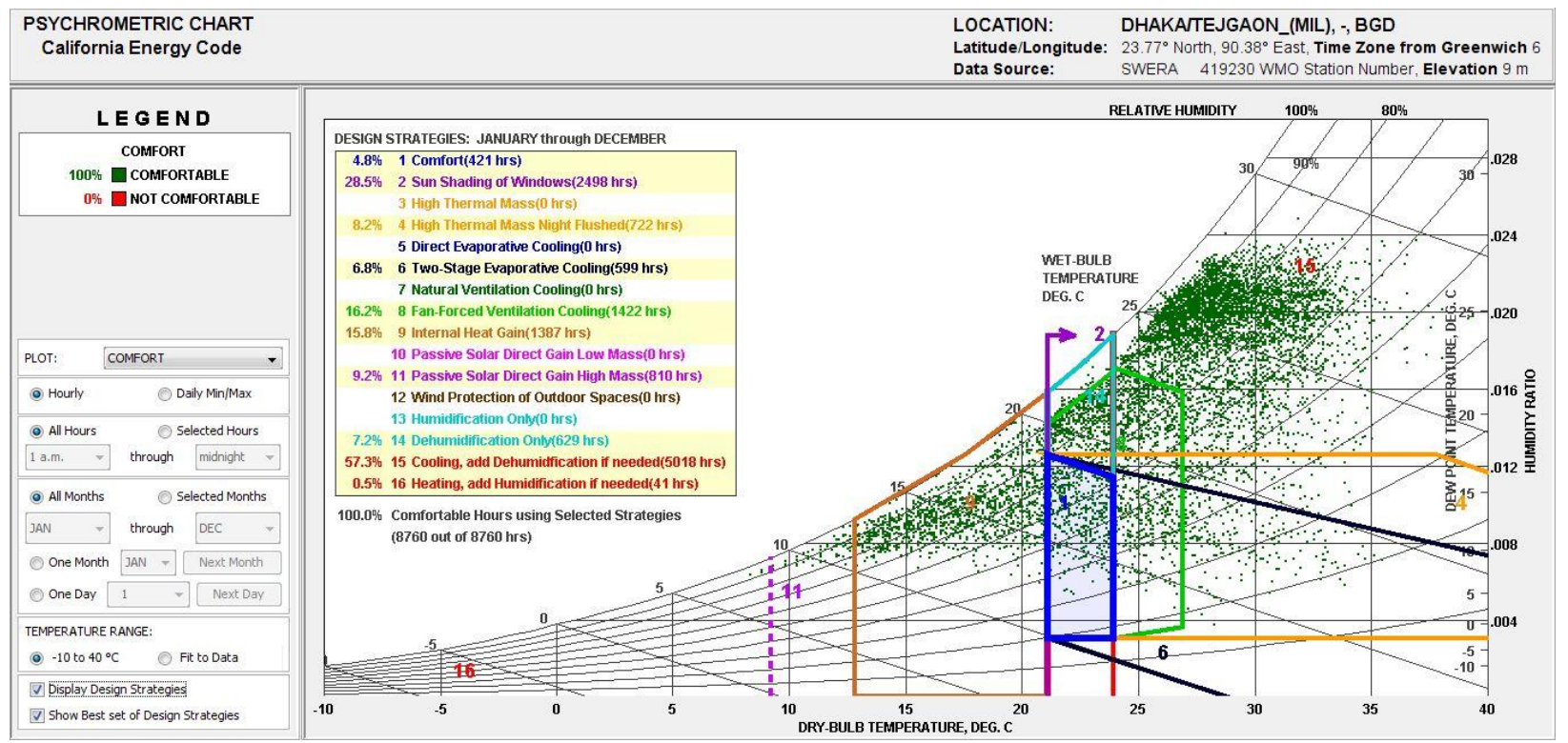

Figure 31: Psychrometric chart

Psychrometric chart (Figure 31) is a graphical representation of physical and thermodynamic properties such as wind direction, wind velocity, dry and wet bulb temperature, humidity, rainfall etc. of an area.

Here, it presents some important factors regarding design strategies in the outdoor area. As, this county is situated in warm humid temperature zone, and Dhaka is at the center of the country, so $57.3 \%$ time of a year is needed to make cooling and dehumidification process for designing any public space. $28.5 \%$ time of a year needs shade in outdoor place to provide protection from direct sunlight. $16.2 \%$ time is needed to control the direction of the wind in a year to provide comfort. So, providing water body and designing vegetation according to the study analysis can create a microclimate for the area which can give a better comfort zone for the city dwellers.

\subsection{Ground Water Level}

Due to rapid and uncontrolled urbanization, the built-up areas are increased during the last 25 years, which causes the increase of impervious area upon the ground surface of Dhaka. As a result, obstructions occur for natural drainage pattern (Mowla et al. 2013). So, intervals occurred in groundwater recharge system from surface run off volume. It causes the declination of groundwater level for the entire city area (Figure 32 and 33). People of Dhaka city depends on groundwater for drinking and other daily purposes. Declination of groundwater level will cause scarcity of pure water for city dwellers soon. In research, it is found that, the declining trend of groundwater level in Dhaka city is 3 meters per year (Islam, et.al., 2017). Throughout the last 30 years, drastic declination of groundwater level is observed in the Dhanmondi area which is near 
the study area. Population density is one of the major elements to create a scarcity of groundwater, as urbanization brings more people to an area and increases the demand for pure water. Characteristics of soil play a vital role in water table depth ((Islam, et.al., 2017).
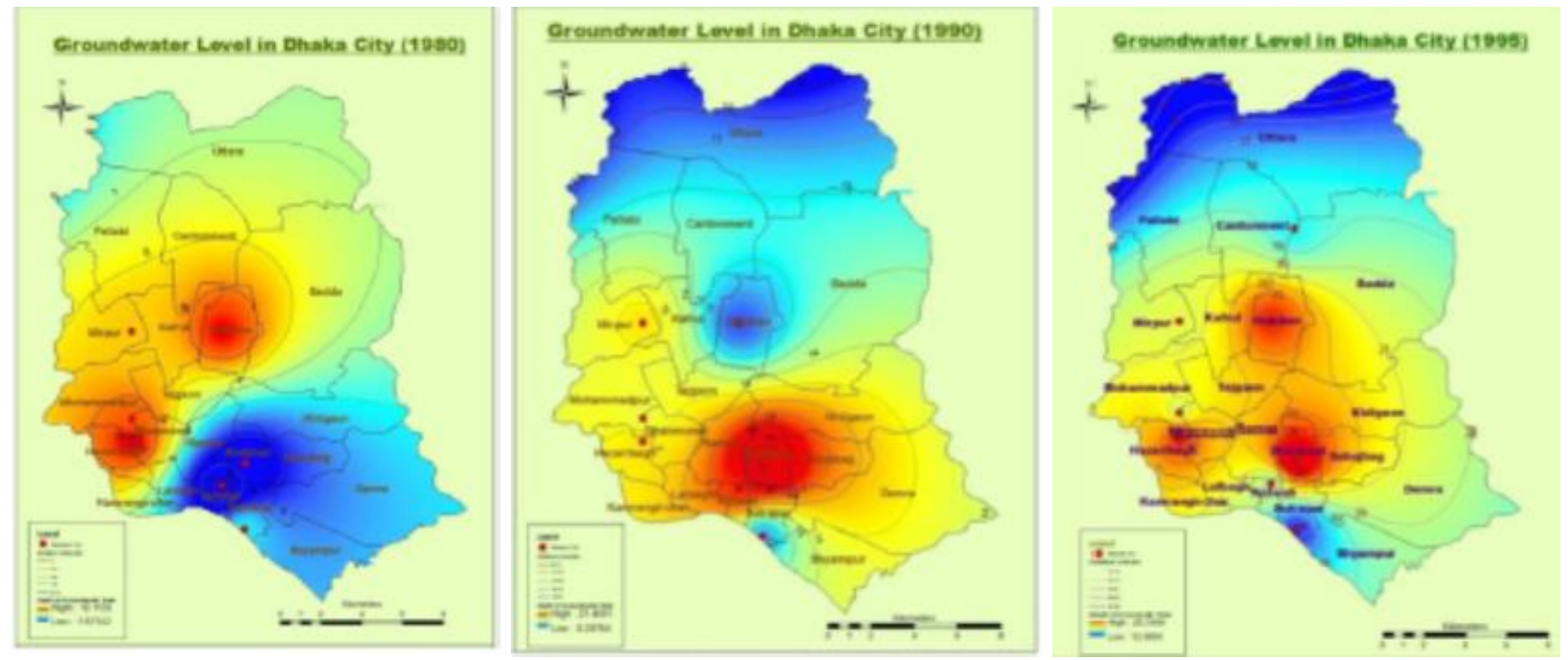

Figure 32: Depth of ground water table at the year of 1980, 1990 and 1995 (Islam et al. 2017)
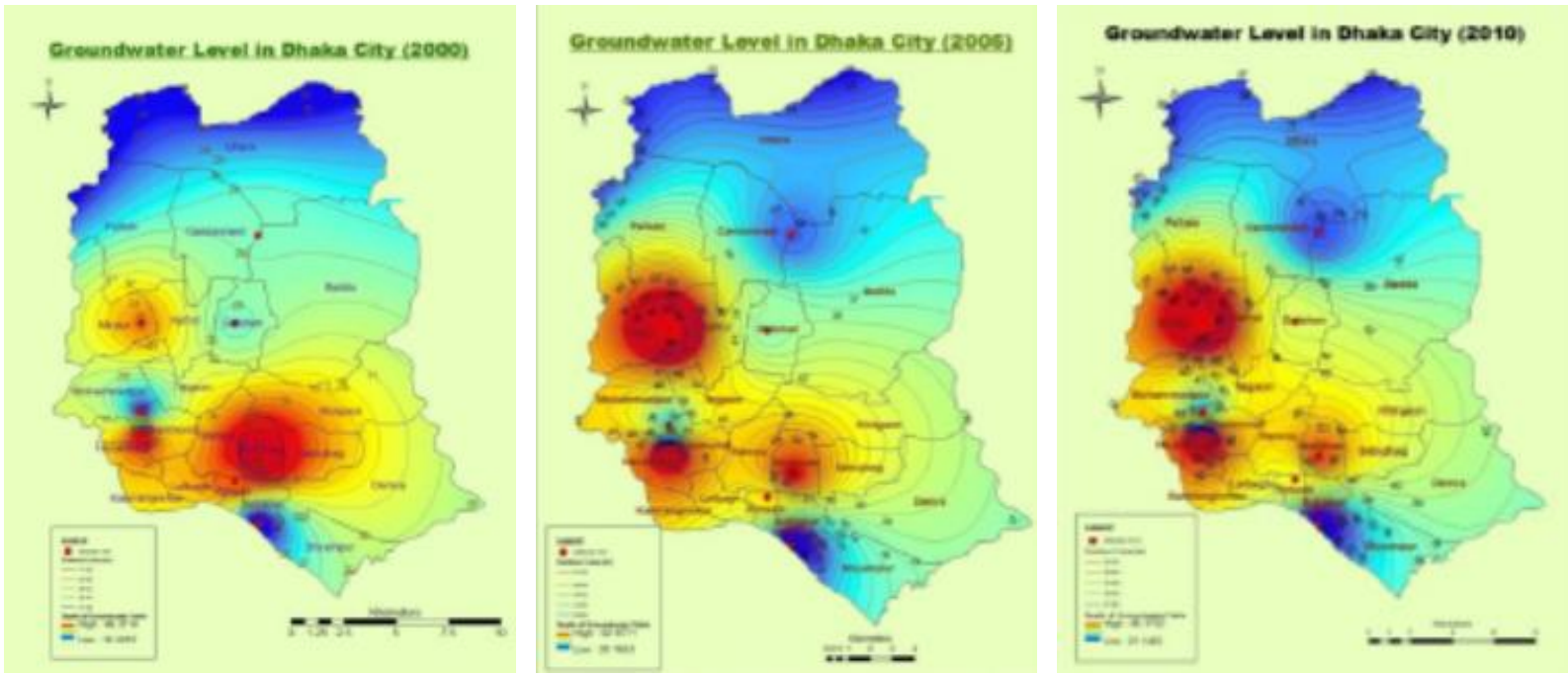

Figure 33: Depth of ground water table at the year of 2000, 2005 and 2010 (Islam et al.2017)

\subsection{Change in wetland and water body}

Historically, the urban life of Dhaka was interwoven with the system of rivers, canals, lakes and ponds (Datta and Mandal 2017 and Mowla 2008). Figure 34 is presenting the historical scenario of the waterways. In earlier days, these natural canals served as the basic drainage system for the city during the flood and rainy season. These were crisscrossing the whole land of Dhaka city. The 
surface runoff was absorbed and retain with these canals and rest were discharged to the surrounding rivers (Mowla and Islam 2013). This water network also served as a way of transportation along with railway and road. It was decided that the emphasis will be given to the canal system of Dhaka city while developing any urban area. Later, we became reluctant to this decision and as a result, we lost our water resources and natural drainage system.

Through study, it is found that the western part of Dhaka had 13 khals and the eastern part of Dhaka had 27 khals (Mowla and Islam 2013). The study also showed that 84 percent of water bodies and wetlands are disappeared since 1947 (Datta and Mandal 2017). According to WASA, there are 43 canals flowing through Dhaka city. Among those, 17 of these canals exist only in the map. Most of the surviving 21 canals have been reduced to shallow streams of filthy sewer water (Khan 2017). The remaining canals are filled up with dumping waste or encroached by illegal settlers while shrinking stream of the canal ends up as part slums which are also filled up with tons of garbage dumped on it every day (Datta and Mandal 2017).

An analysis has been done through ArcGIS to find out the changes in wetlands. Image classification tools are used here to make those maps. Different colors are used to show the differences which occurred from time to time. Figure 35 and 36 show the changes occurred on land surface and wetlands of Dhaka city due to urbanization from 1989 to 2009. At 1989, there are lots of water bodies and wetlands. In 1999, within 10 years, a big change has happened at northern part of the city. It is noticed here that, the direction of growth pattern starts from the southwest and going towards at the north-east portion of the city where the maximum low lands were located. The vegetation portion and bare soil portion become lower from time to time. Figure 36 is showing future prediction also. So, in the near future, if we are not planning accordingly, the growth pattern shows, the built-up area will cover every bit of surface area. Based on the analysis, it can be said that, the whole city will go under water due to flood events or rainfall.

The filling pattern of lowlands does not follow any rule. Once the center of the city was higher than the surrounding area, now it is now the lower portion from the surrounding land area. In previous, the rain runoff was following the surrounding lower lands, now it stacked in the center of the city as the city center part becomes the lower land portion corresponding the other land portion of the city. It seems, the whole city in working like a basin. So, during rainfall water cannot flow any direction. It stacks in the same place for a long time and causes the inundation.

However, the previous city planning does not consider this situation to fill up the land maintaining a rule so that the center city will not work as a basin. In the early days, it was the opposite and the city center work as the roof of an umbrella.

Necessary steps should take to make a guideline to make any further development in terms of city planning. Some big waterbodies are needed to build up to work as the retaining portion for the city to minimize the problem in some extents. Every locality should need to follow the elevation guide rule for leveling the ground level. The initiative is needed to take from the government level. In some areas of the city, slum people take some steps to make their accommodation higher than the surrounding ground level. Sometimes they go over to the lake areas. Though the practice of taken land illegally is not accepted but the method they are using to prevent them from flood can be a model for making guideline for the city in present condition. 


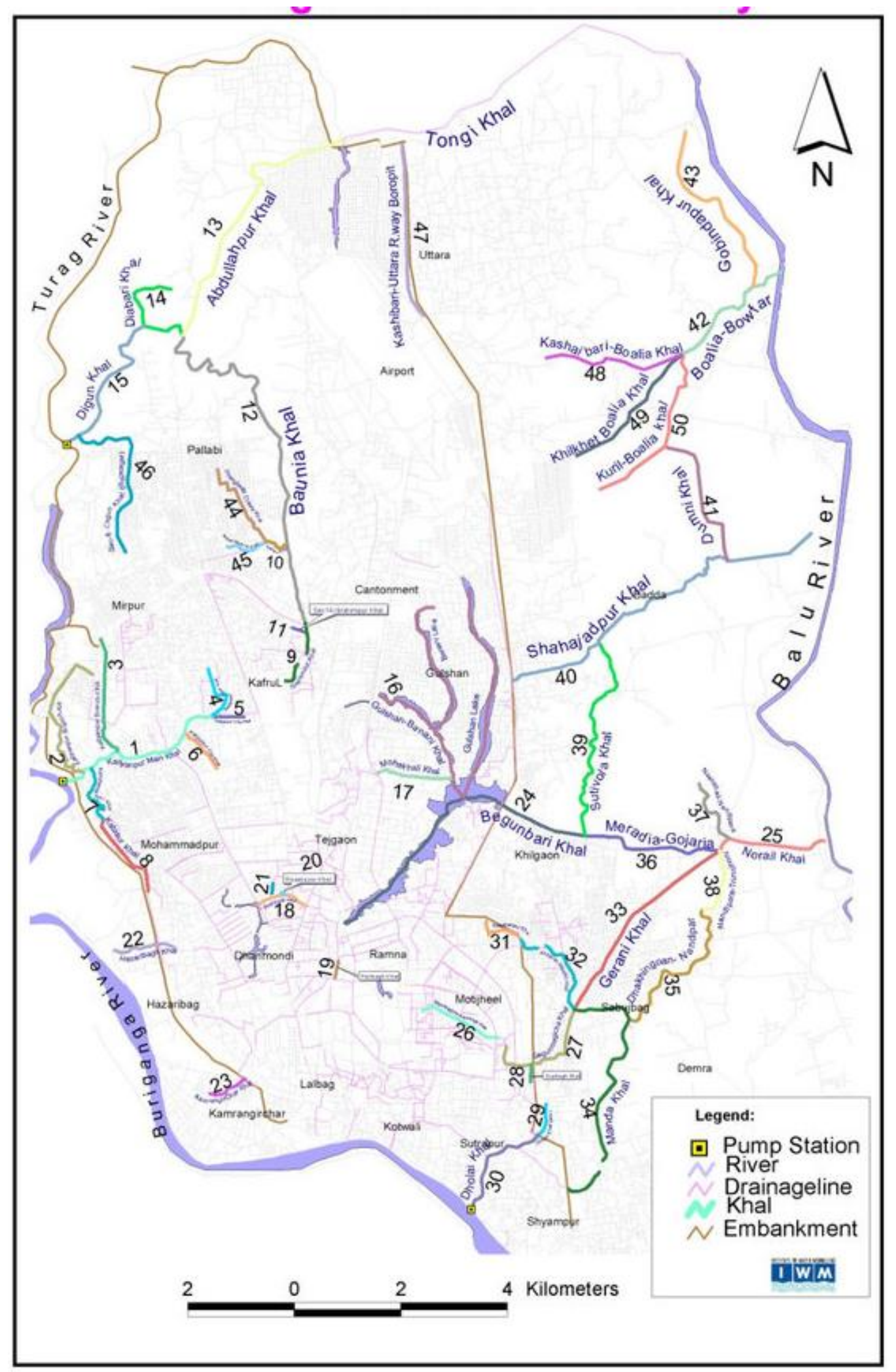

Figure 34: Map of Dhaka canals (Ishtiaque et al. 2014) 


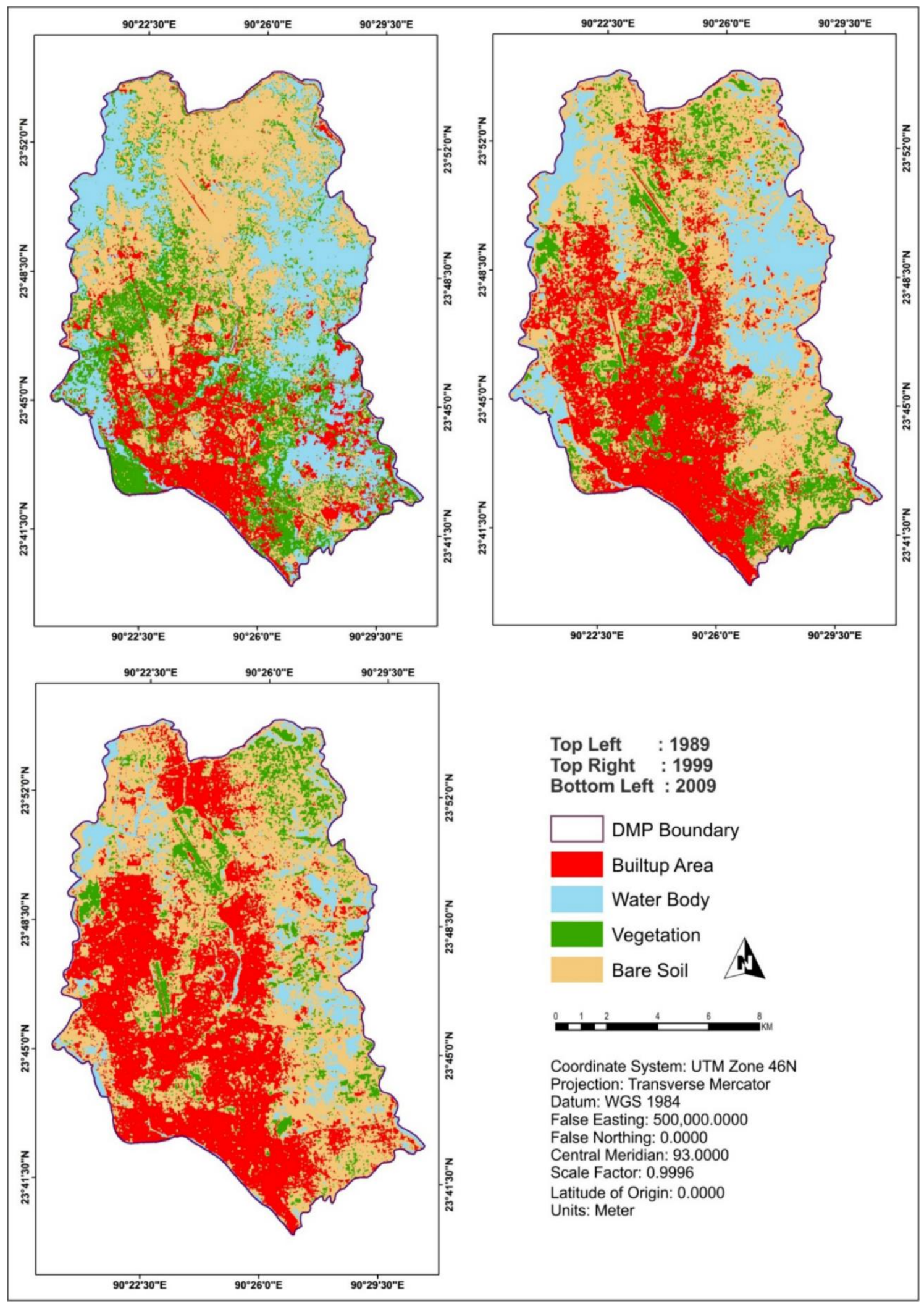

Figure 35: Changes in wetlands and water bodies (Rahman and Zhang, 2018) 


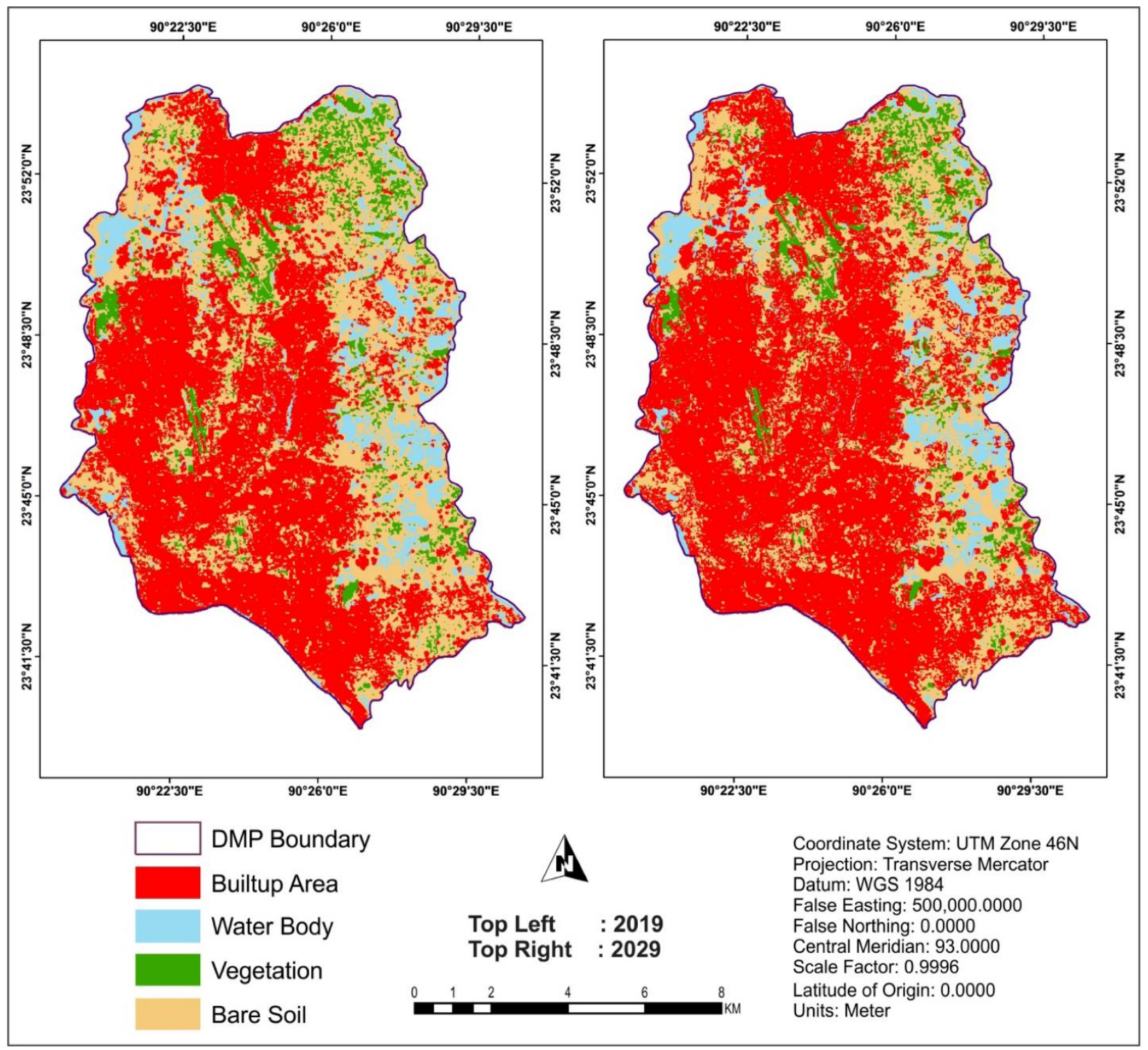

Figure 36: Future prediction of changes in wetlands and water bodies (Rahman and Zhang, 2018)

A comparison is made here through study and analysis the images from Google earth pro regarding wetlands loss from 1978 to 2019 (Figure 37, 38 and 39). Image classification tools in ArcMap are used here to make the map of existing wetlands situation.

The comparison shows that the wetlands and water bodies are decreasing at an alarming rate. The table is showing that the area covered by wetlands significantly reduced over time. In 2009, almost all wetlands are disappeared except only 53.6 hectors. The map of 2019 shows that there are almost no low lands inside the Dhaka city. 

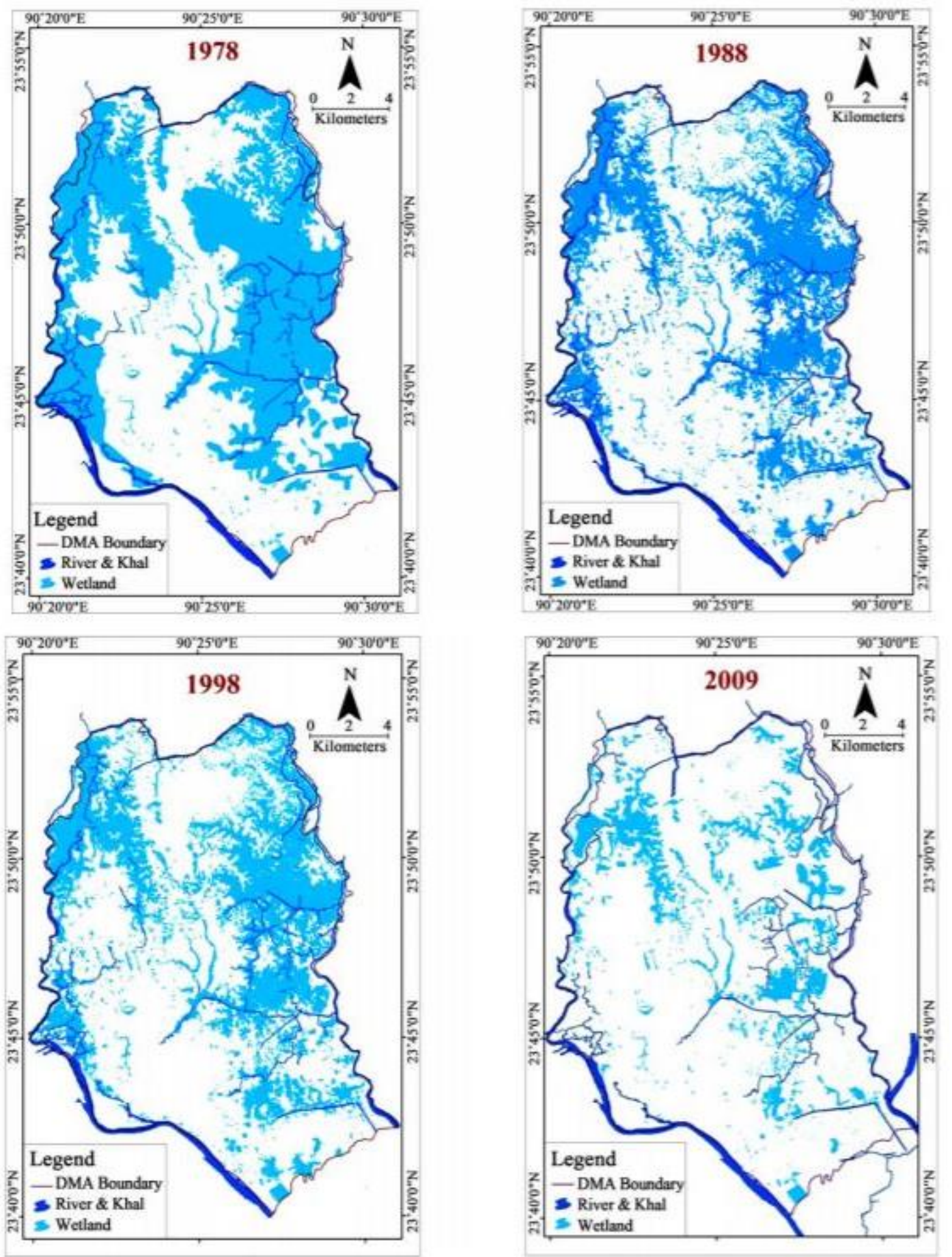

Figure 37: Wetlands in Dhaka metropolitan area between 1978 and 2009 (Mahmud et al. 2011) 
Table 1. Wetland and Rivers \& Khals in DMA between 1978 and 2009.

\begin{tabular}{ccccc}
\hline & \multicolumn{4}{c}{ Year } \\
\cline { 2 - 5 } & 1978 & 1988 & 1998 & 2009 \\
\hline Wetlands & 130.17 & 127.85 & 106.93 & 53.6 \\
Rivers \& Khals & 29 & 21.03 & 18.72 & 10.28 \\
\hline
\end{tabular}

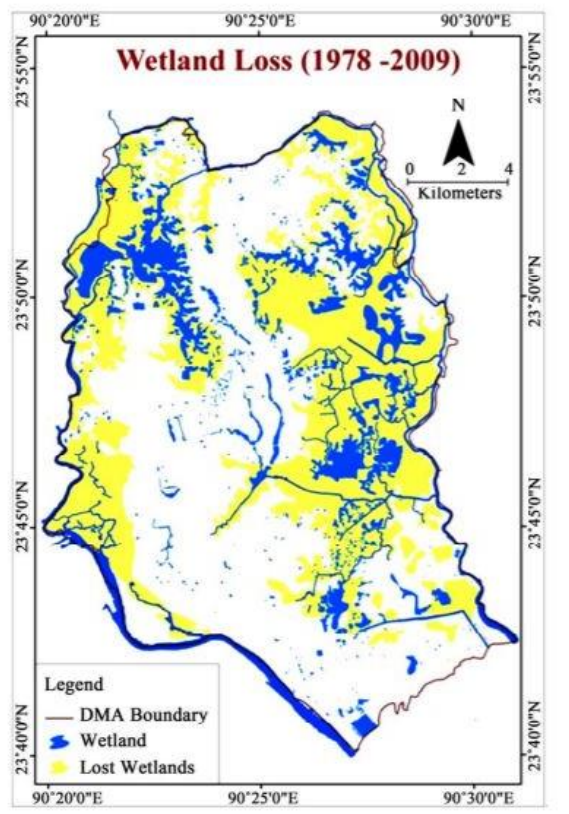

Figure 4. Wetland Loss in DMA between 1978 and 2009.

Figure 38: Chart showing decreasing condition of wetlands and Map showing the comparison of wetland loss between 1978 and 2009 (Ishtiaque et al. 2014, Mahmud et al. 2011)

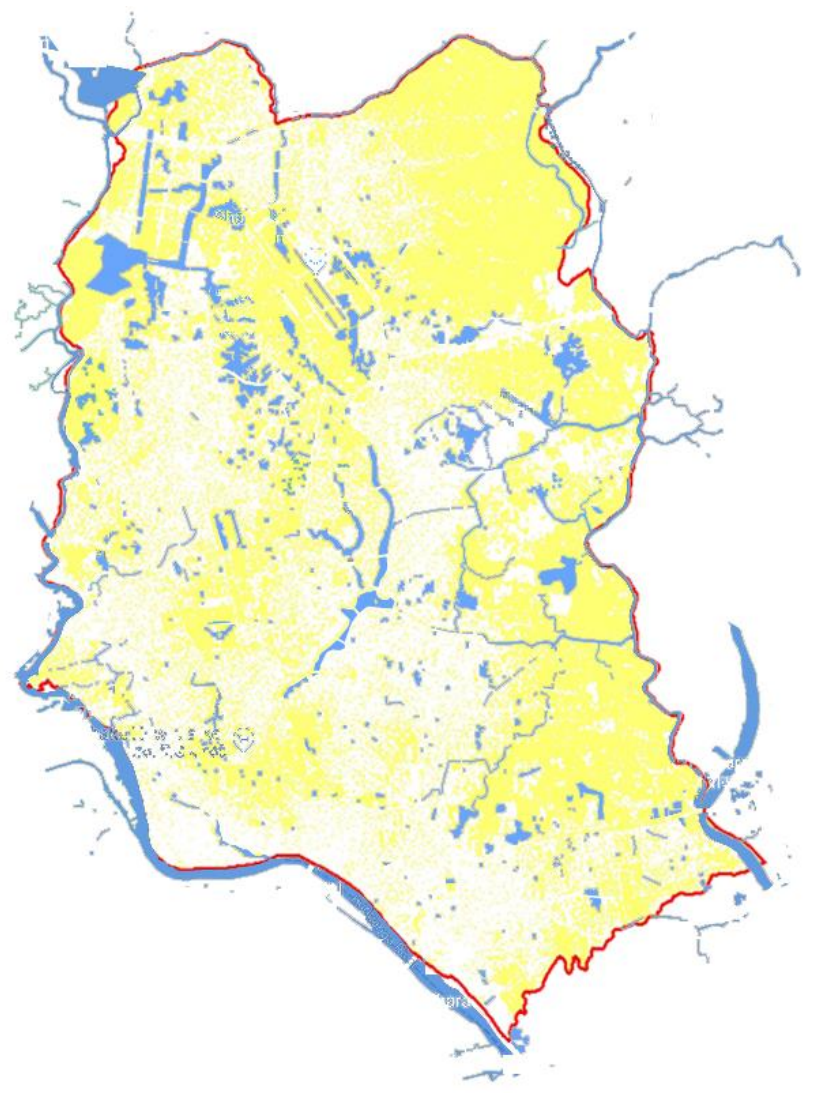

Figure 39: Wetland condition at 2019 


\subsection{Finding out lost water connection}

After imposing the historic map of wetlands of Dhaka city and the present map showing only the wetlands of Dhaka city, the lost ways are found out. Eight connections are marked here, where in early days, water channels were present (Datta and Mandal, 2017) (Figure 40).

Location 1 is situated between Dhanmondi lake and Hatirjeel-Begunbari water channel. It is now named as Panthapath road which was a water channel and now there is a road under which a box culvert was created.

Location 2 is known as Kalyanpur canal which is at its shrinking condition and lost some connections due to Mirpur road and other infrastructure.

Location 3 is situated in the northern part of the city and it is the collection of some small water bodies. These waterbodies lost their connection with each other and with the Turag river at the city periphery.

Location 4 is situated at Dhaka cantonment area. New canals can be created here as an early period and need to be connected to surrounding canals.

Location 5 is the area between Banani lake and Gulshan lake. The area can connect these two water bodies.

Location 6 can be a connection part for Hatirjeel and Begunbari canal with Balu river.

Location 7 is situated at the south-east corner of the city. It is opening the possibilities of widening existing canals and connecting with Balu rivers.

Location 8 is situated in the south-west part of the city. It is about to revitalize the existing khal which is called Dholai khal and link this with the city river, river Buriganga.

These are the possibilities those are found through studies and analyzing the historic and present condition of Dhaka city. A whole analysis was made based on several kind of maps to find out the lost connections of water ways of Dhaka city which have some opportunities to reopen those channels or create some connections to work with the surroundings.

It is obvious that more expert level analysis is needed to come to a decision regarding this matter. Expertise from several fields like hydrologist, civil engineer, planner, architect, landscape architect needs to give their opinion. The local people also need to participate during this decision-making process as whatever is the situation, it is the local people who are finally living with the situation. A project can be taken from the government level to know the opinion about this idea and engage the local people as community participation. It is necessary to take the opinion from the local community for the successful implementation of any kind of urban plan related design project and needs to give the impression of the belongingness of the project. Further, this kind of belongingness helps to keep the area alive and keep maintained. 


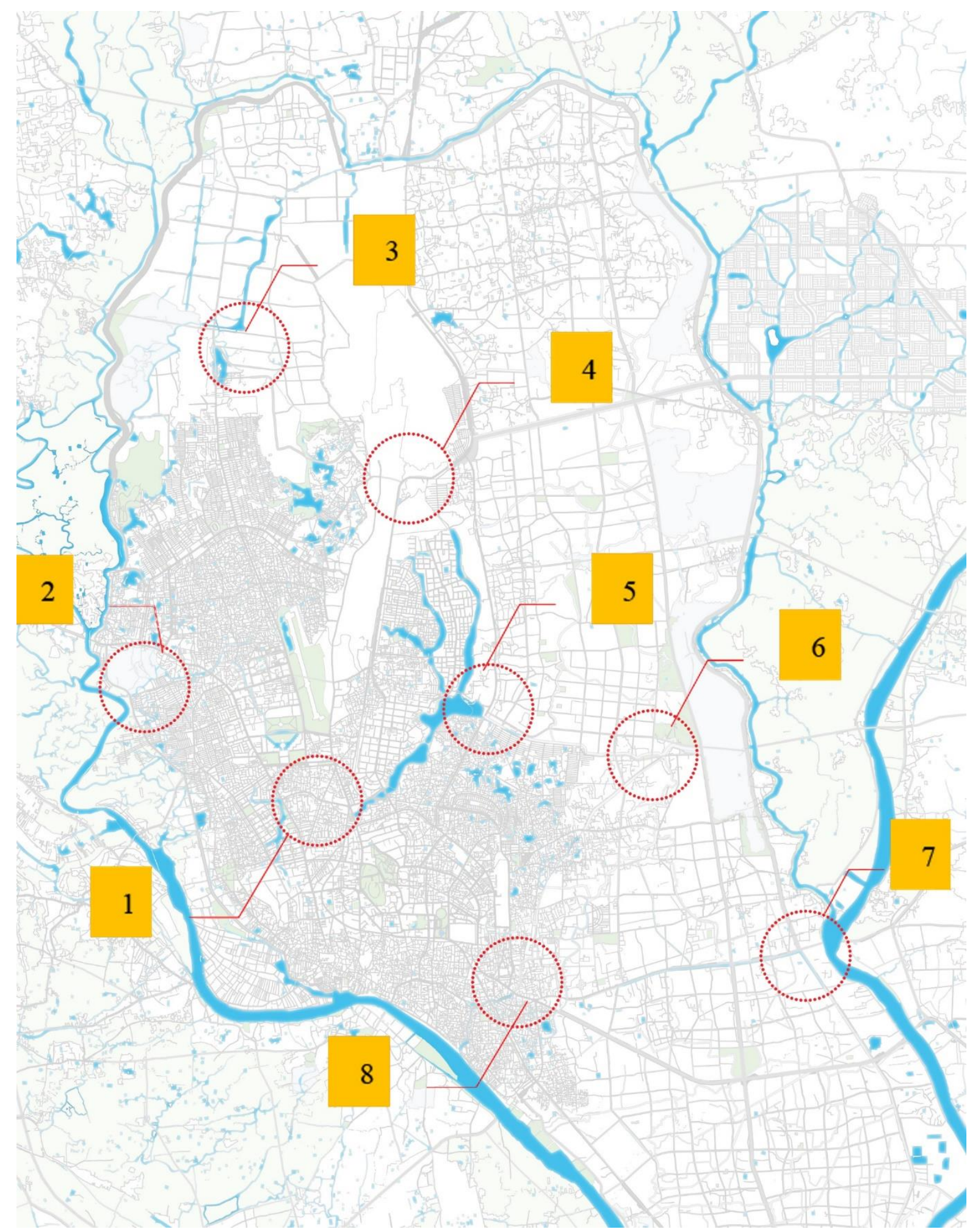

Figure 40: Proposed location for reopen and revitalize the water channels (Datta and Mandal 2017) 


\subsection{Water Flow Direction}

ArcGIS analysis has been done here to find out the direction of water flow. The study is done from using DEM (digital elevation model) data for the area. The resolution of data was $10 \mathrm{~m} \mathrm{X}$ $10 \mathrm{~m}$. To run such kind of analysis, data with better resolution is needed. Unfortunately,

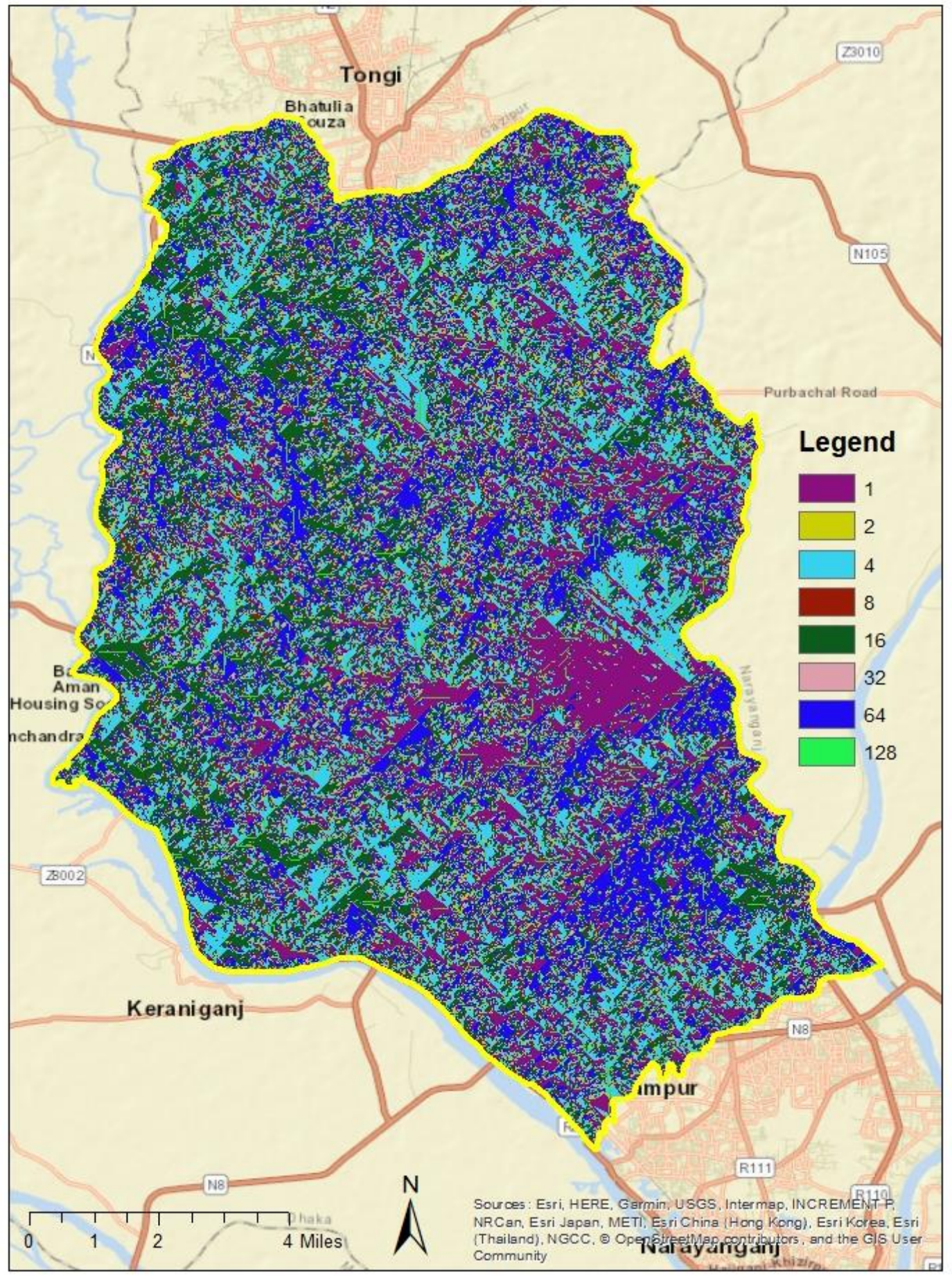

Figure 41: Flow direction map 
Bangladesh does not have that resource to generate meta data for this kind of analysis until now at the public level. Figure 43 shows the steps of the analysis of flow direction method. After getting the map (Figure 41), it is observed that the area does not possess any define water flow direction. So, when rain falls, water is going to every direction at this surface. So, considering this situation, it is quite difficult to make any decision regarding work with high land and low land. Due to lack of better resolution, it was difficult to find the locations of water bodies and existing streams.

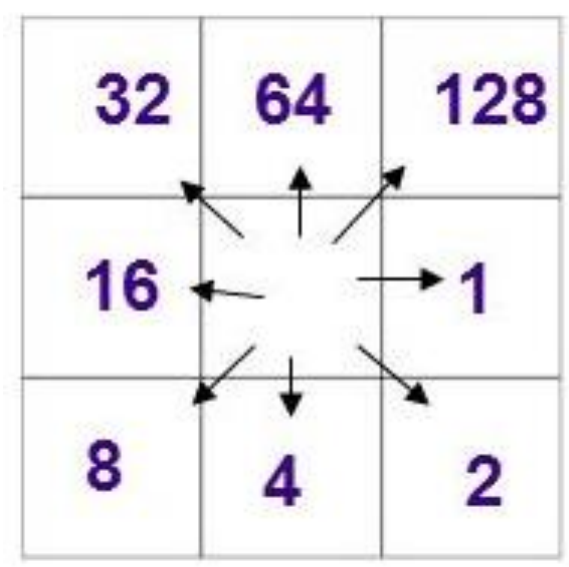

Figure 42: Water flow direction diagram (source: ArcGIS online resource)

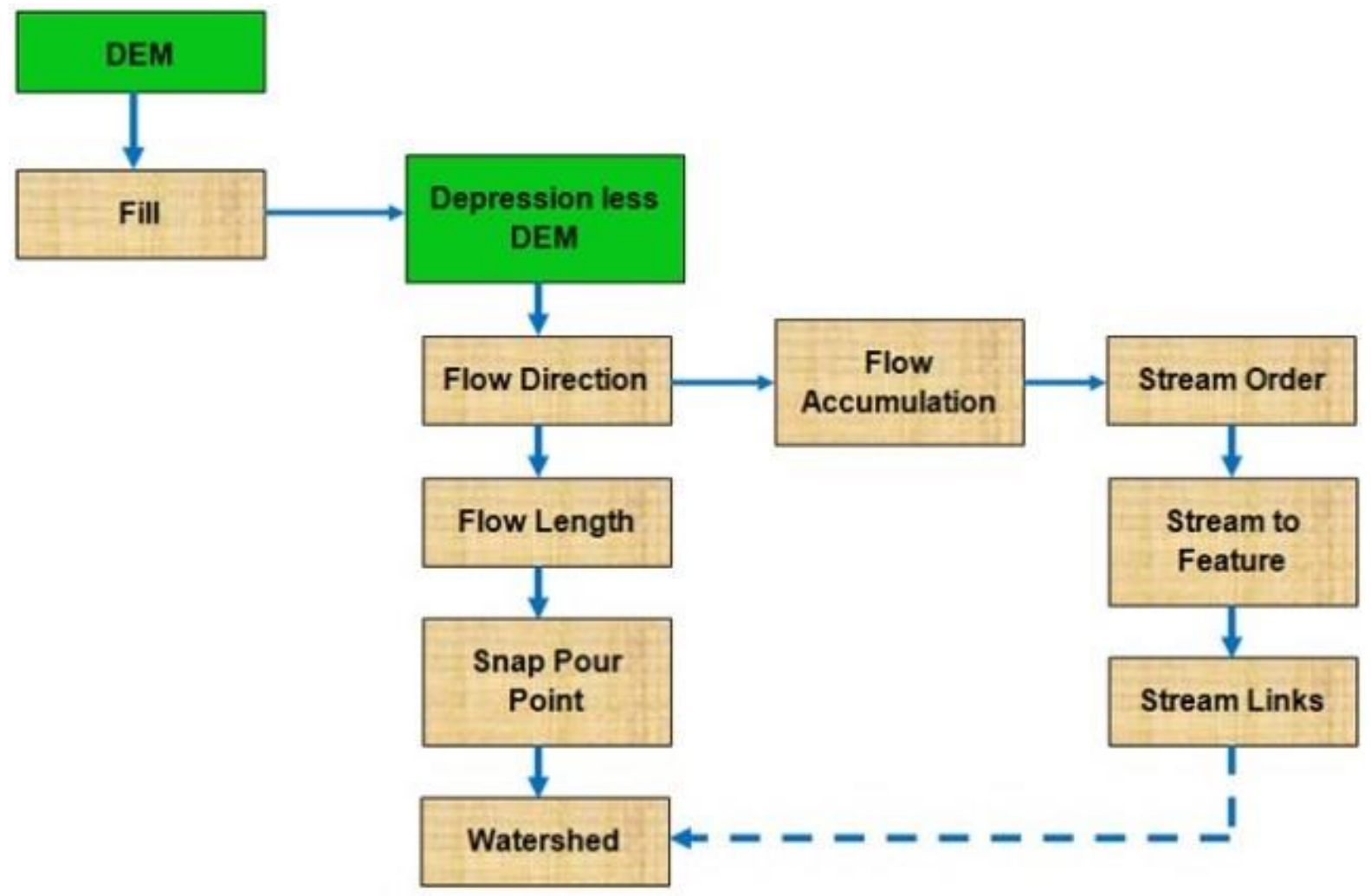

Figure 43: Diagram of flow direction method (source: ArcGIS online resource) 


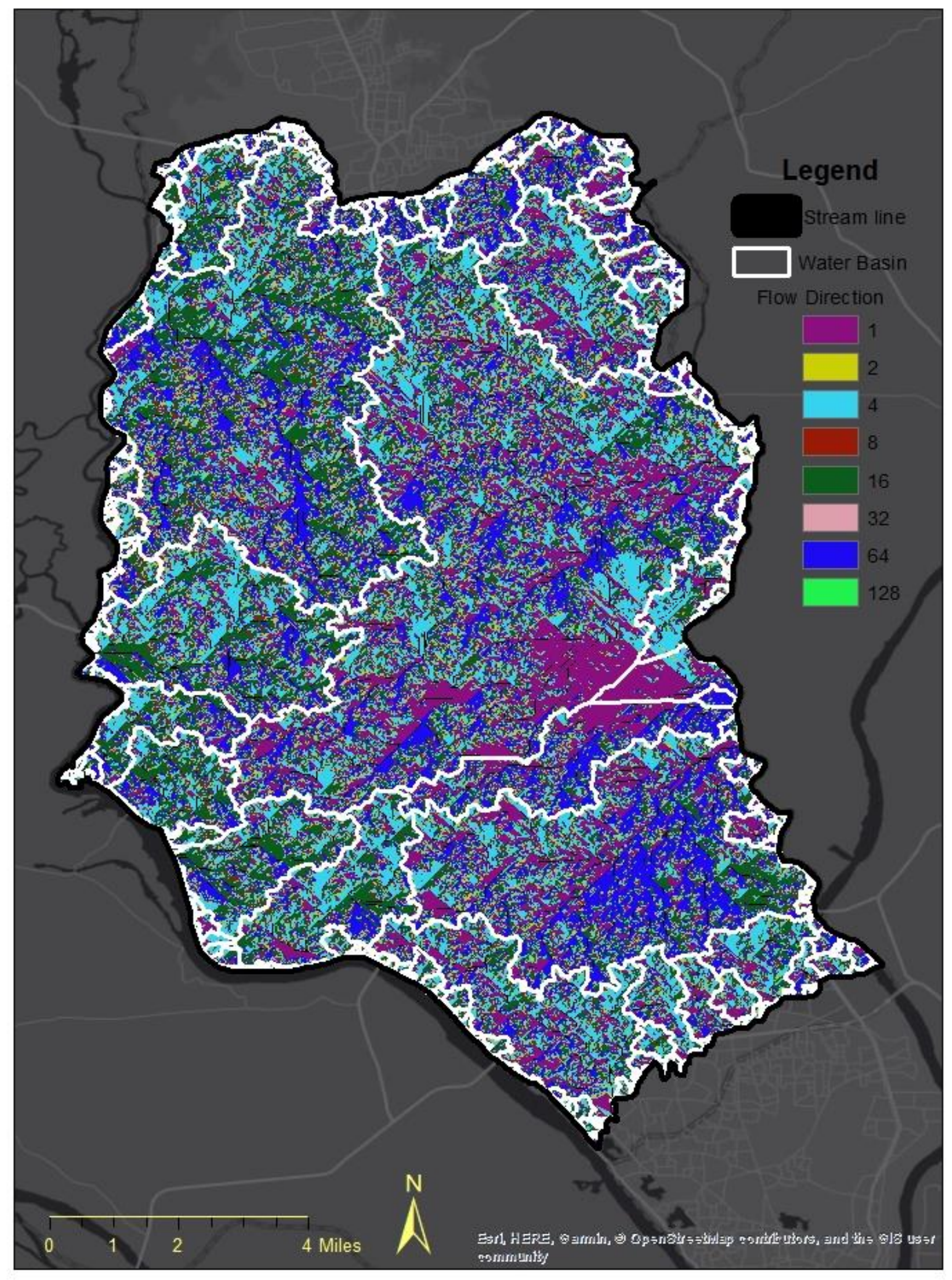

Figure 44: Map of water basin for the Dhaka city 
Watershed map is made through ArcGIS analysis. The steps are shown in the diagram (Figure 45). After dividing the area into the water basin (Figure 44), it is observed that the situation is the same. Within a watershed, water flows at every direction. So, still, there is no definite direction for water to flow from one place to another. Every color defines the direction of water flow. The numerical values (Figure 42) show the water amount and flow direction of every cell. Here the conclusion has been made like the solution to water problem needs to be solved locally. There is no way to find an overall solution only changing one part of the city. Every area which are facing any water-related issue due to surface runoff, needs to consider the local characteristics to solve the problem.

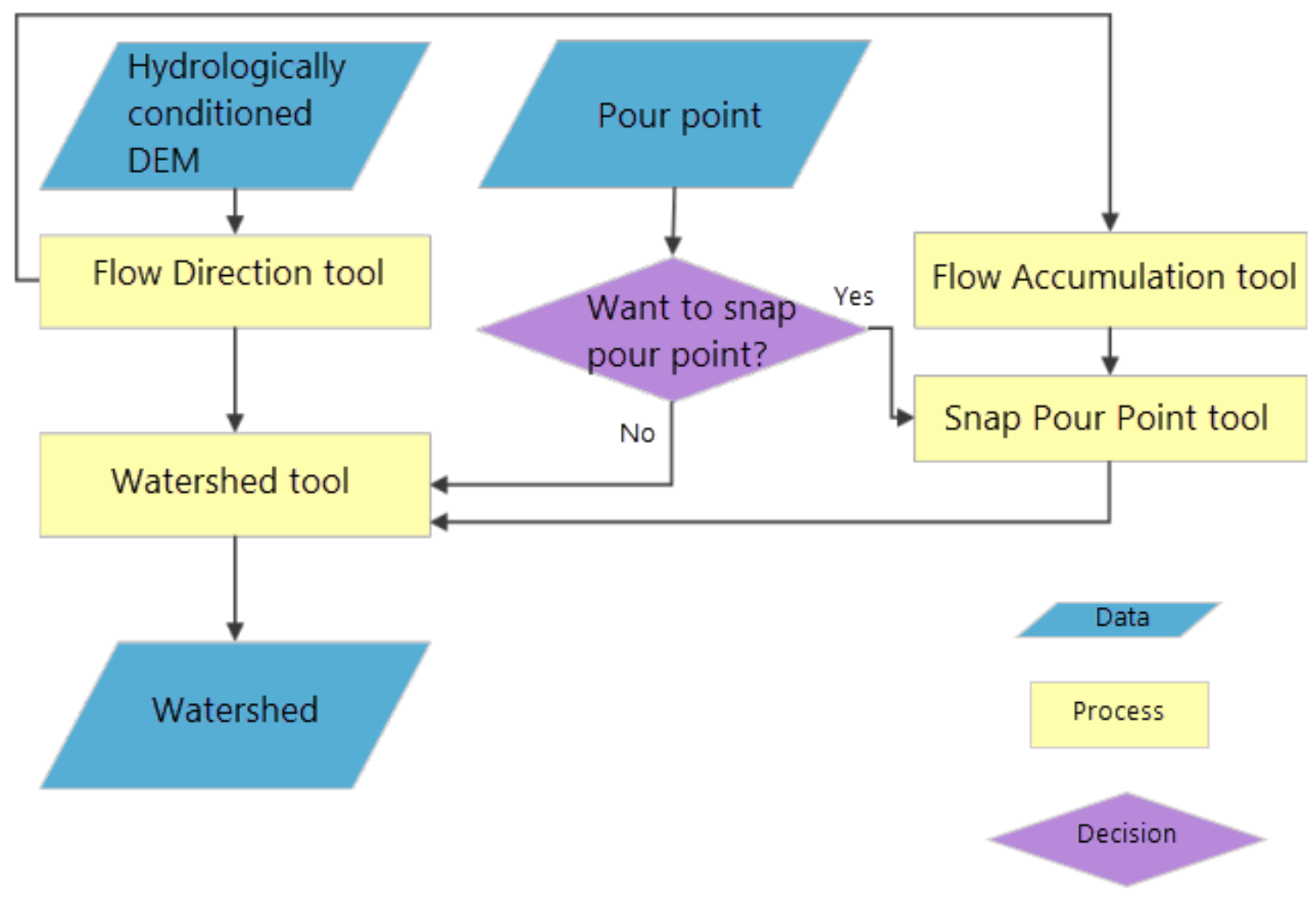

Figure 45: Diagram of creating water basin (source: ArcGIS online resource)

Here to determine the streamline, number 1000 is used for value cell. For Bangladesh, there is no specific value chart to designate streamlines. So, the streamline map is been imposed on an existing map of waterbody where black color showing the area of waterways and water bodies. That means, where the line does not meet with existing water body, it indicates the ways of surface runoff (Figure 46). As water is flowing through every type of landcover, so during monsoon, some portion of these areas where surface runoff occurs face inundation or water stagnation situation. 


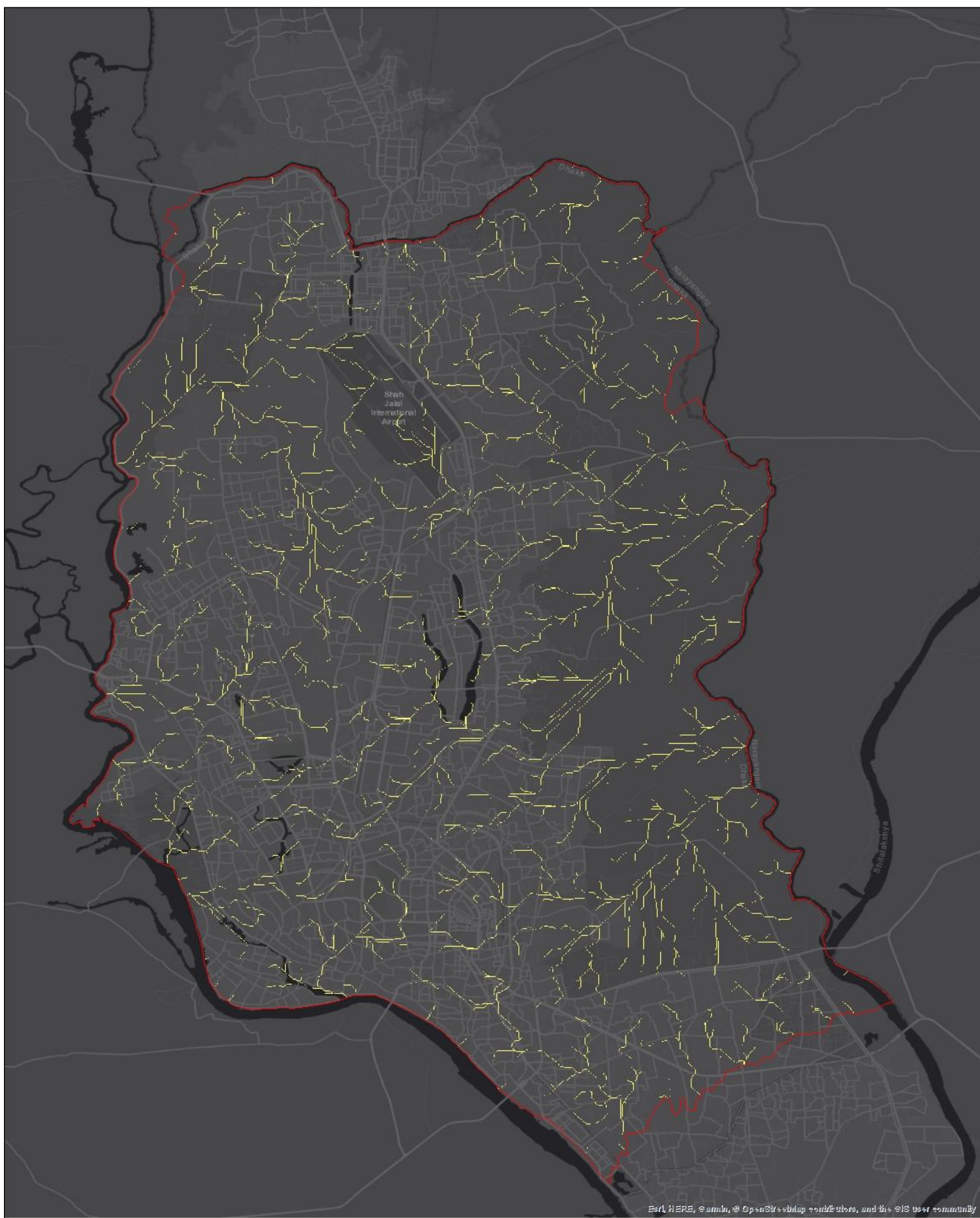

\section{Legend}

Stream line / Surface run Off path

Existing Water Body

Boundary of Dhaka Metropolitan City

\section{Map Showing Surface Run off}

Made by Debsree Mandal

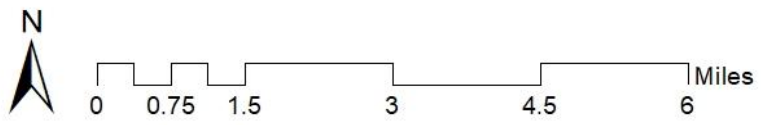

Figure 46: Map of showing streamlines 


\subsection{Finding out the site area}

After analyzing the local condition and the scenario of the surrounding area (Figure 47) in terms of flooding situation and water flow direction and water accumulation criteria, some proposals are given here regarding to make any solution.

- We need local based solution for mitigating inundation area or to solve the problem for waterlogging.

- Every locality should have different criteria. Some basic rules can be developed to make a prototype for all areas those are suffering due to waterlogging during the rainy season.

- According to the characteristics of an area, the solution should be defined.

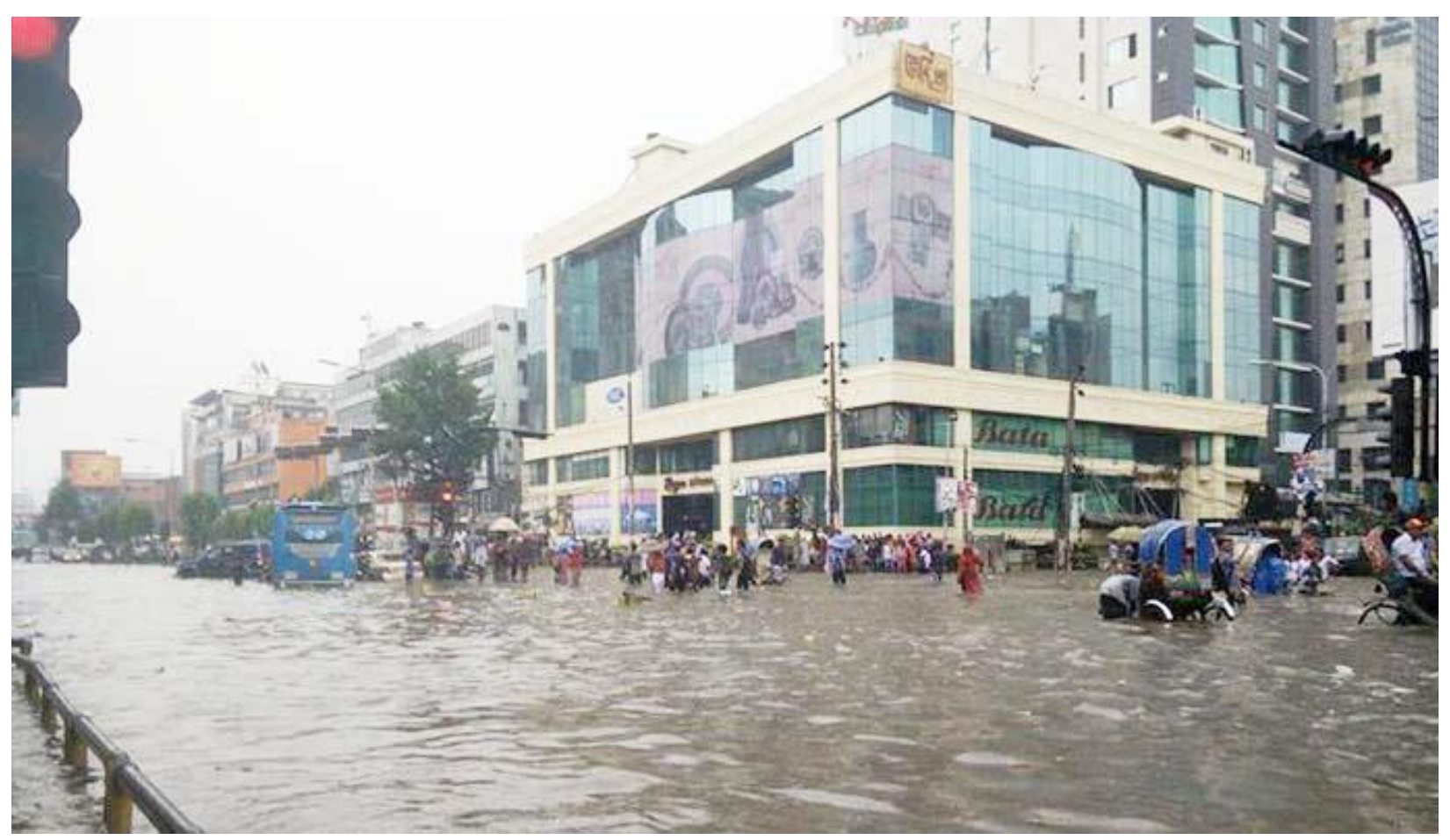

Figure 47: Inundation scenario near study area (Cars and Bangladeshi floods, 2019)

At this point, some decisions are made here

- Analyzing 8 points of lost waterways, Location 1 (Figure 48) is selected as the study area.

- Criteria for selecting the site:

Present Inundation condition: The areas where the regular inundation occurs for any kind of rainfall even for thirty minutes, Panthapath road area is one of those areas.

Commercially Importance: The area is one of the main commercial districts for the entire city. 
Number of Users affected: Every day more than 50,000 people come here for different purposes from every working level like, students, workers, professionals, job holders, patients and visitors and more than 20,000 people lives here per square kilometers. So, in terms of the number of affected people from numerous levels, So, this area is important.

City planning proposal: The proposals are discussed regarding the inundation issues for this area and proposals are coming to open the culverts and bring back the lost water channels for Dhaka city.

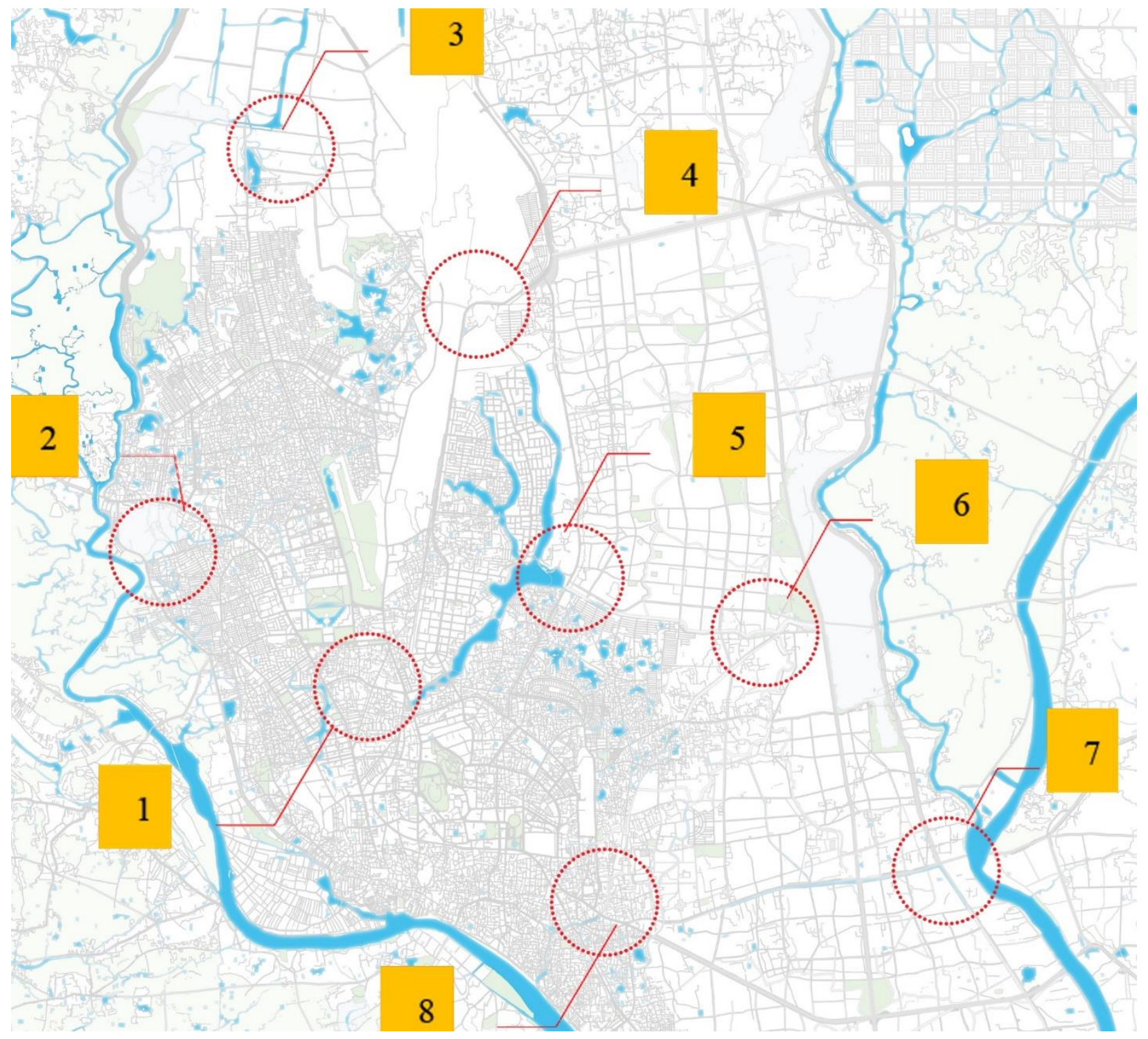

Figure 48: Map of showing lost waterways (Datta and Mandal 2017) 


\section{CHAPTER 3. SITE ANALYSIS}

\subsection{Location Description}

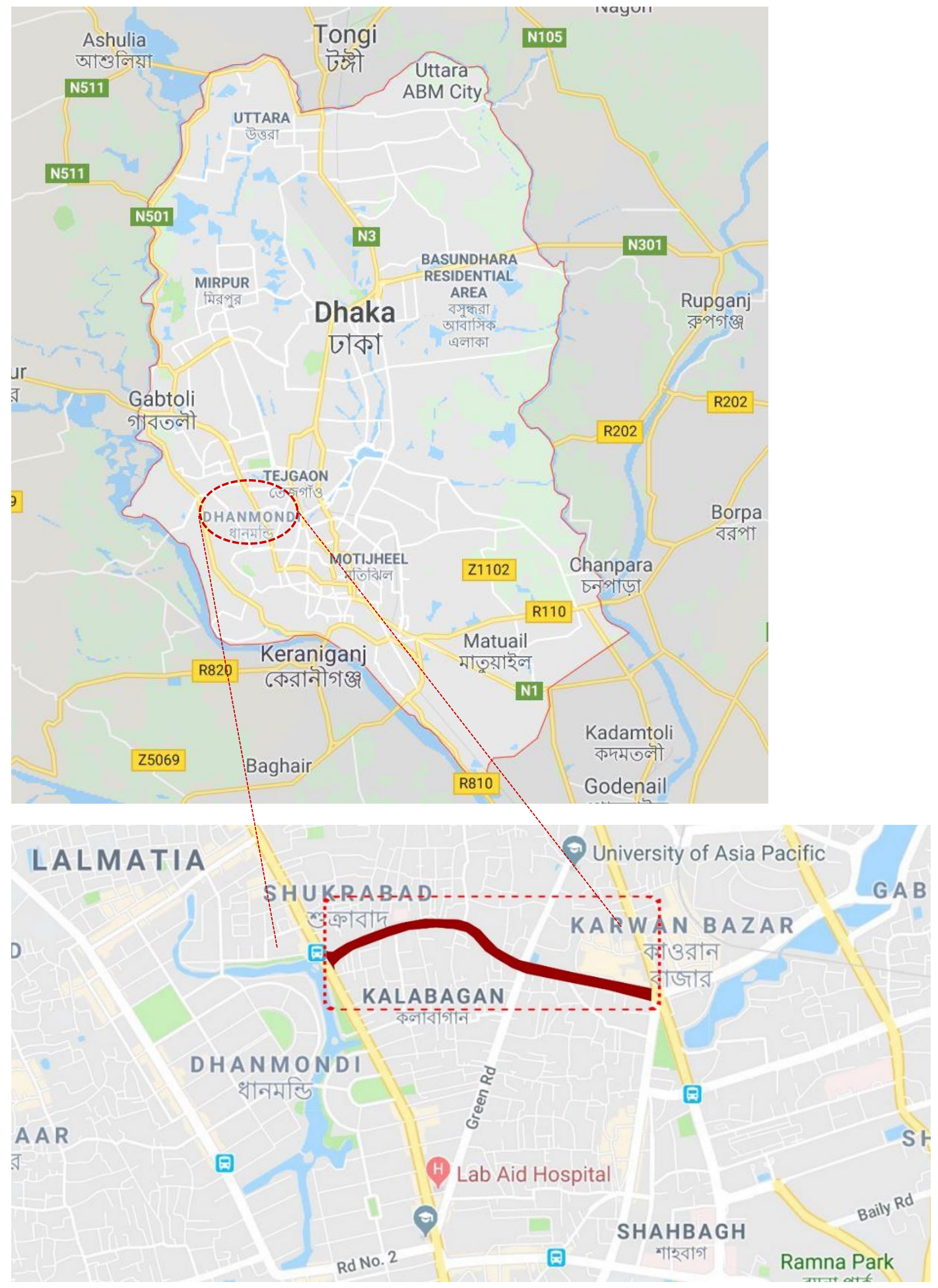

Figure 49: Location of study area (source: google map) 
The study area is located almost at the center of the western part of Dhaka (Figure 49, 50 and 51). It is recognized as Panthapath road. It is an important eastern western route at Karwan Bazar region of Dhaka city. The total length of Panthapath road is approximately $1.7 \mathrm{~km}$. It is the secondary road connecting two major roads, one is Mirpur road at the west side, and another is Kazi Nazrul Islam Avenue at the east side. At the east side, the study road is ended up with SAARC Fountain Circle. The west end is called Russel Square.

Another secondary road, which is called Green rood crosses the Panthapath road in about area from north to south between those two major roads. Green road is important for having different types of the institutional center.

At present, there are two water bodies. One is at the west side, Dhanmondi lake and another is at the east side, Hatirjeel-Begunari water channel. Begunbari channel is the main drainage channel for the whole city. $15 \%$ of total runoff of Dhaka city, can be carried out with this channel. There was originally a passage linking Hatirjeel-Begunbari with Dhanmondi water. In the late 1980s, the East-West route was built. The route construction was completed in 1995. At Hatirjeel-Begunbari portion, water route filled up changed and Bangladesh Film Development Corporation (FDC) and Hotel Pan Pacific Sonargaon were built there.

The development has been particularly powerful in the business, banking, manufacturing, telecommunications and service sectors, while business, hotels and restaurants remain as a crucial component of the Dhaka system. The main business districts of the city include Panthapath. Bashundhara city shopping mall is located here which develop the economy not only for this area but also for Dhaka city with providing spaces for numerous high-tech manufacturers, corporations and shops. This is one of the largest shopping malls in Southeast Asia. It is the 19-storey corporate office of Bashundhara Group containing retail shops, theme parks, fitness center, swimming pool, food court, cinema complex etc. Every day, more than 25,000 people come here to visit this place.

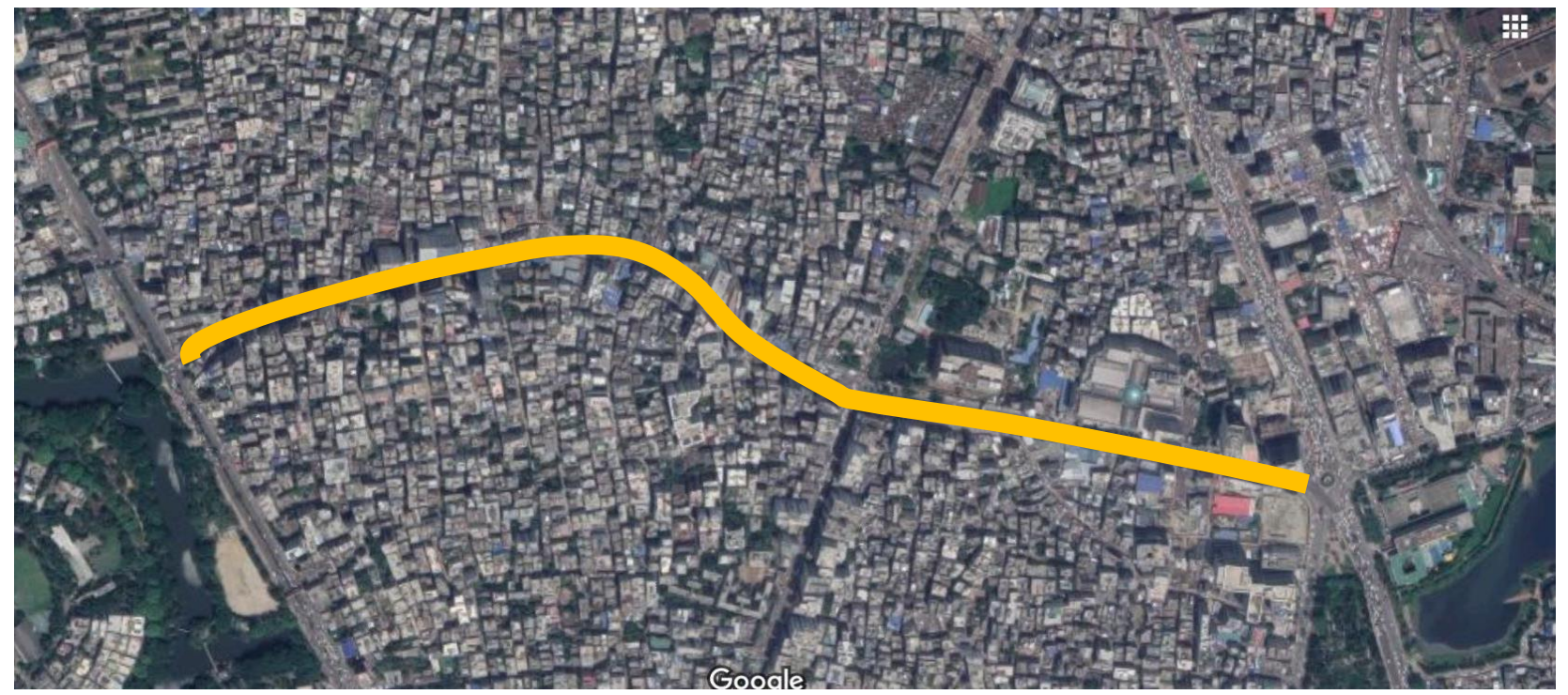

Figure 50: Showing the density of the area (source: google map) 


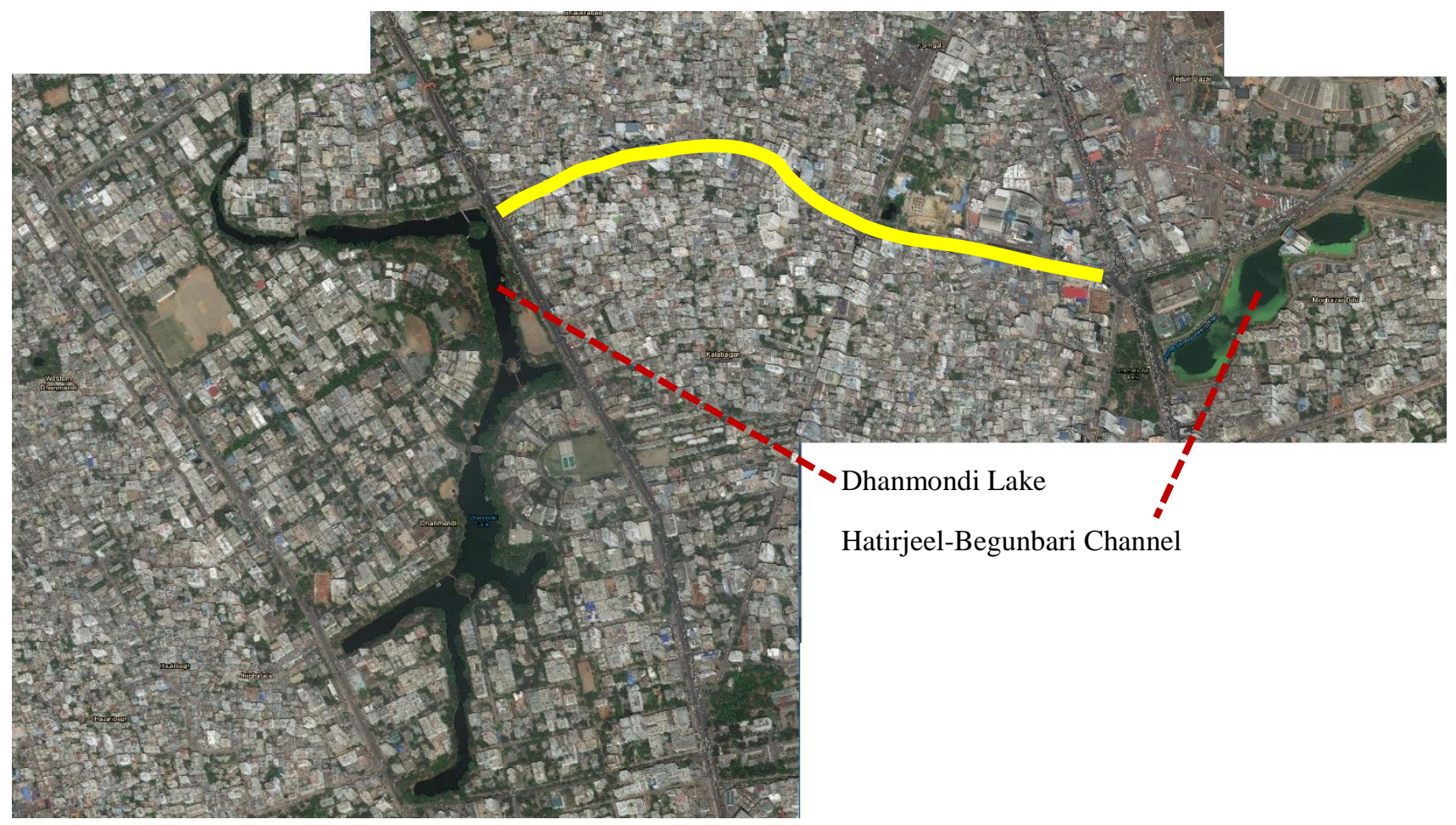

Figure 51: Showing the location of existing water body at the both end of the study area. (source: google map)

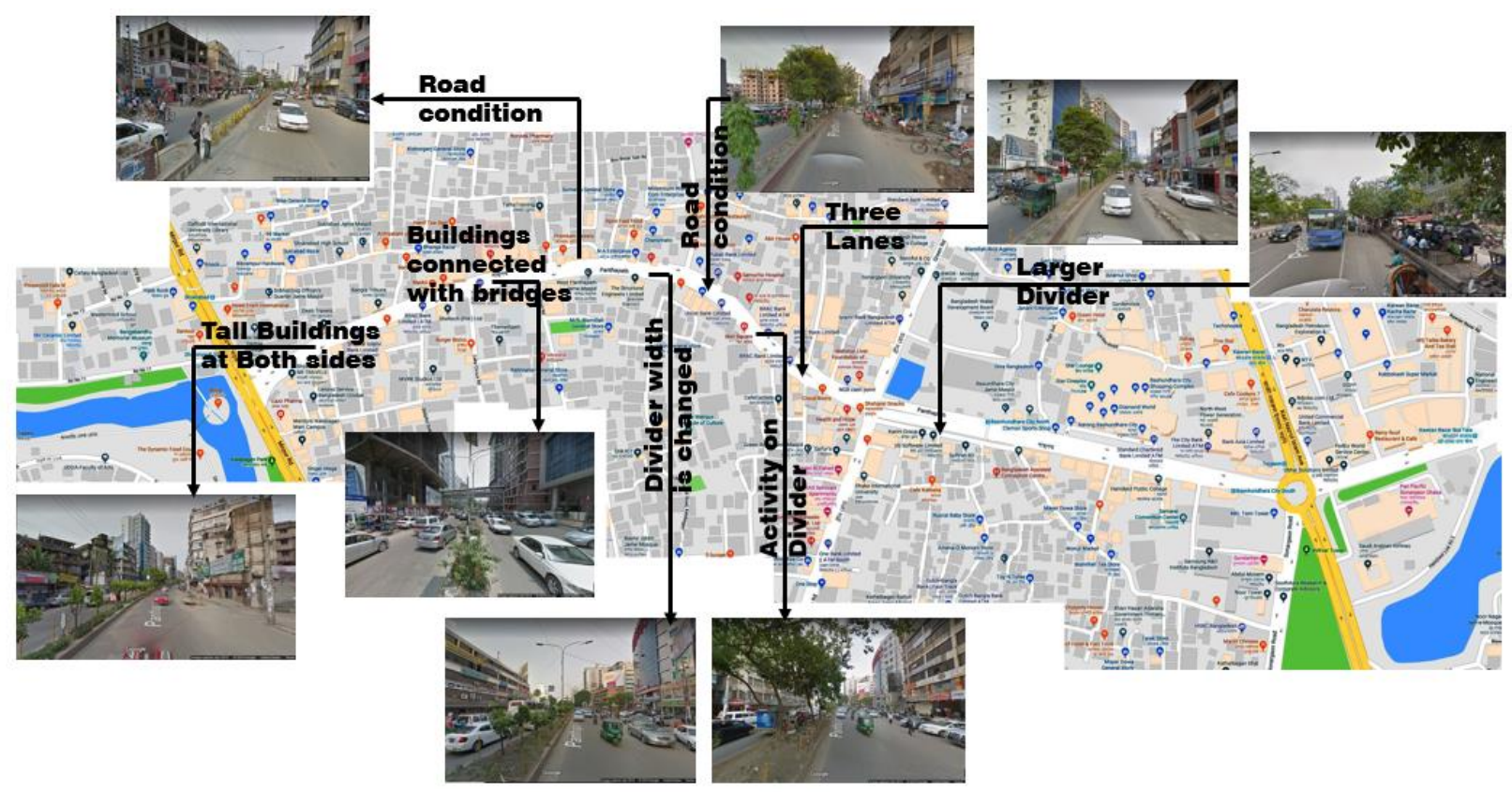

Figure 52: Showing existing road condition of the study area 
Other landmarks area Square Hospital, Samorita Hospital, Unique Trade Area etc. There are two mosques are located here.

Figure 52 is presenting the road condition of the study area. In general, both sides of the road are occupied with tall buildings. Most of the tall buildings are more than ten storied. There are buildings under ten storied and under five storied also. In most cases, the tall buildings are Hospitals, shopping malls, banks or mixed-used commercial buildings.

There are two overhead pedestrian bridges. One is open for public and located at the eastern part of the study area. Another is belonging to Square Hospital and it is connected to two tall buildings. There is no access from ground level for this western bridge.

The road area has two leans. The divider has different types of width thought out the road. Sometimes the divider is working as planter box, in some part, only some elements are used to make the division. Where the divider has width, which is more than five feet, people use that portion as their resting places and make roadside tea stalls. Thus, the divider becomes occupied with several activities.

The pedestrian level is higher from the road level and the height differs from six inches to one foot. Every building has an entry at the pedestrian level. Some buildings have a side entry from where the vehicles can go to a parking lot, which is situated at basement level and lower from road level.

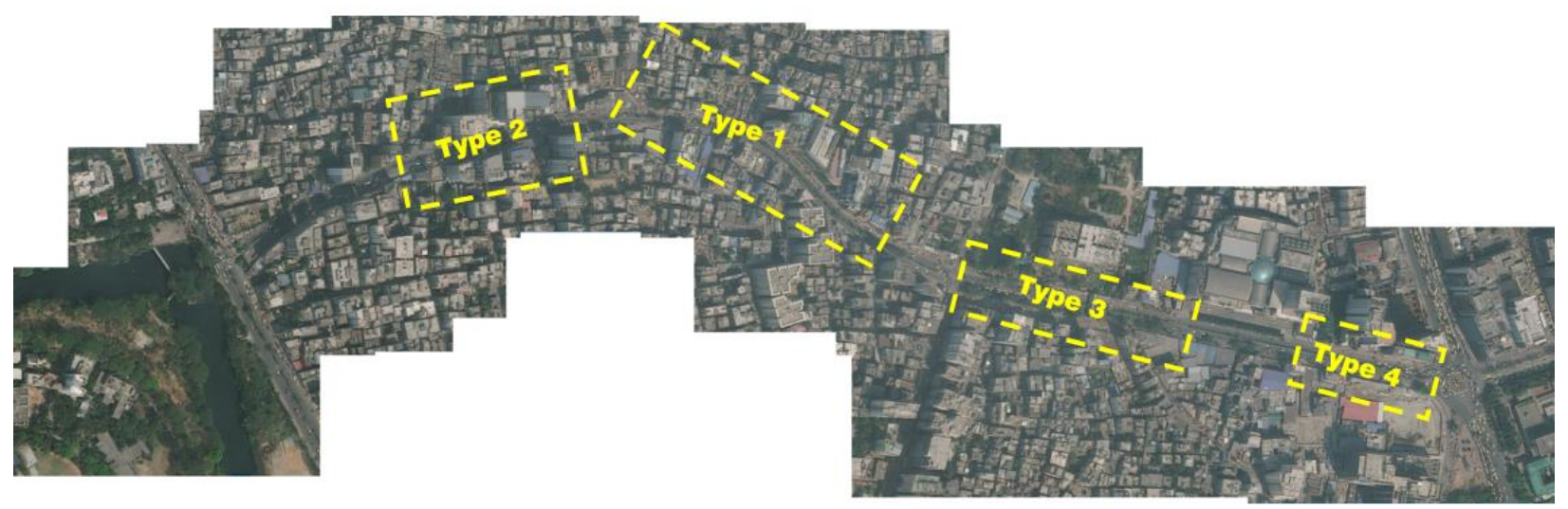

Figure 53: Divide the area to show different situation (base map source: google map)

For analyzing purpose, the whole study area is divided into four portions. It helps to detect different types of elements those the area is having, and which is helpful to understand the character of this area.

Type 1 (Figure 54) is the typical overall condition for the study area (Figure 55). The tall buildings are occupied at the both side of the road. The Road is very busy with different types of vehicle. This road is very busy and there is no separate route for different types of vehicles. Sometimes people use the road instead of pedestrian and it makes the whole area very congested and tough for both vehicle and walkers. 


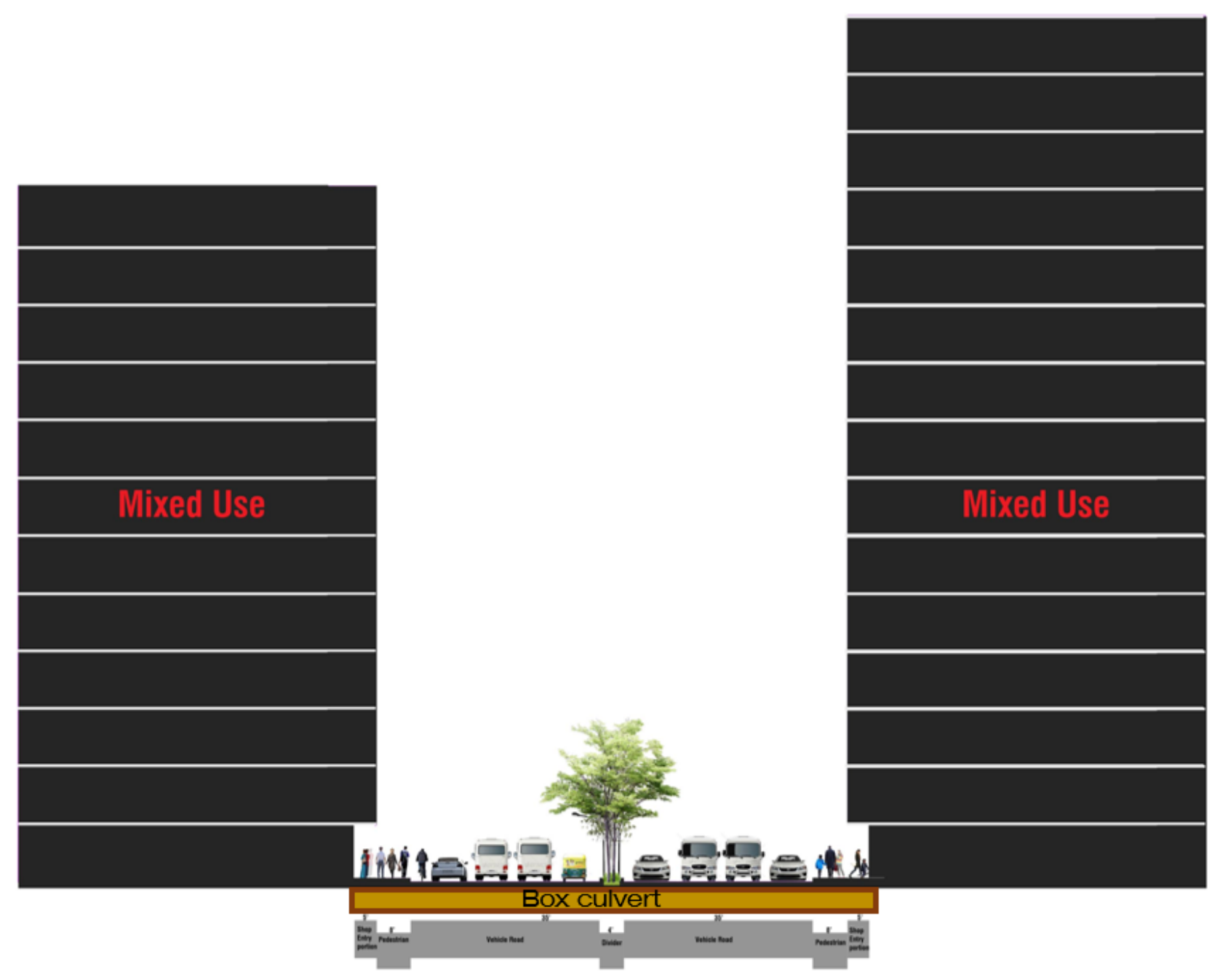

Figure 54: Showing situation for type 1.
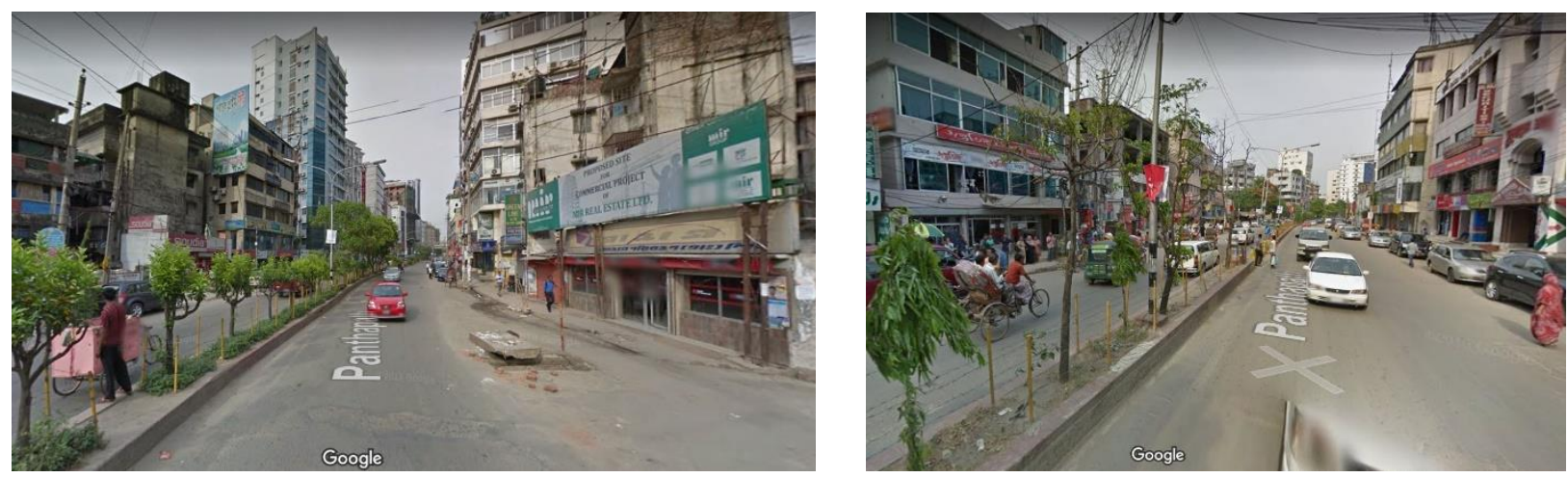

Figure 55: Images of typical condition (source: google map)

Type 2 (Figure 56, 57) is showing the bridge condition of this road. One bridge is connected to two tall buildings. The area under the bridge is the same as before, type 1, except the trees are not that much tall at that portion and there is no tree directly under the bridge. 


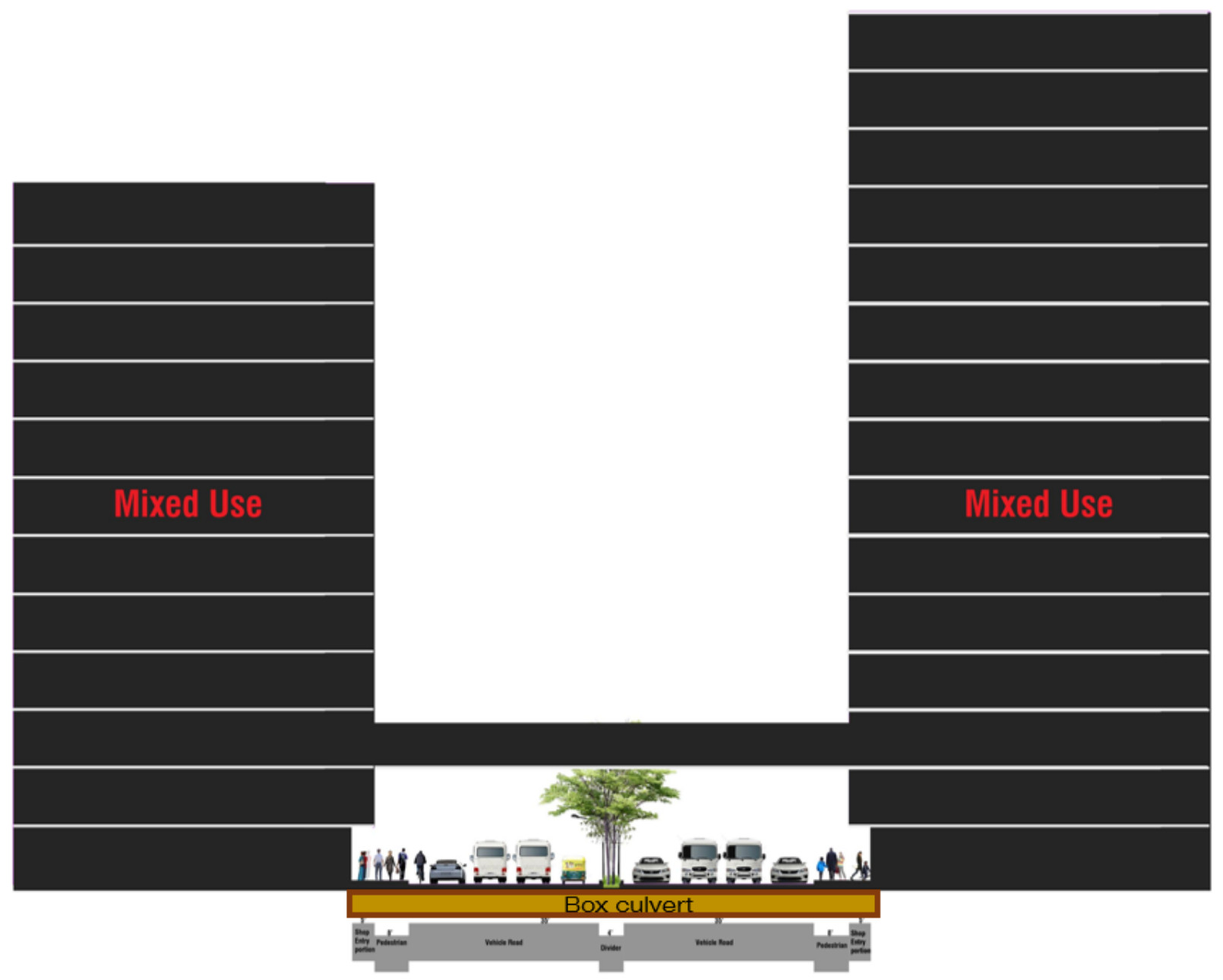

Figure 56: Showing situation for type 2.
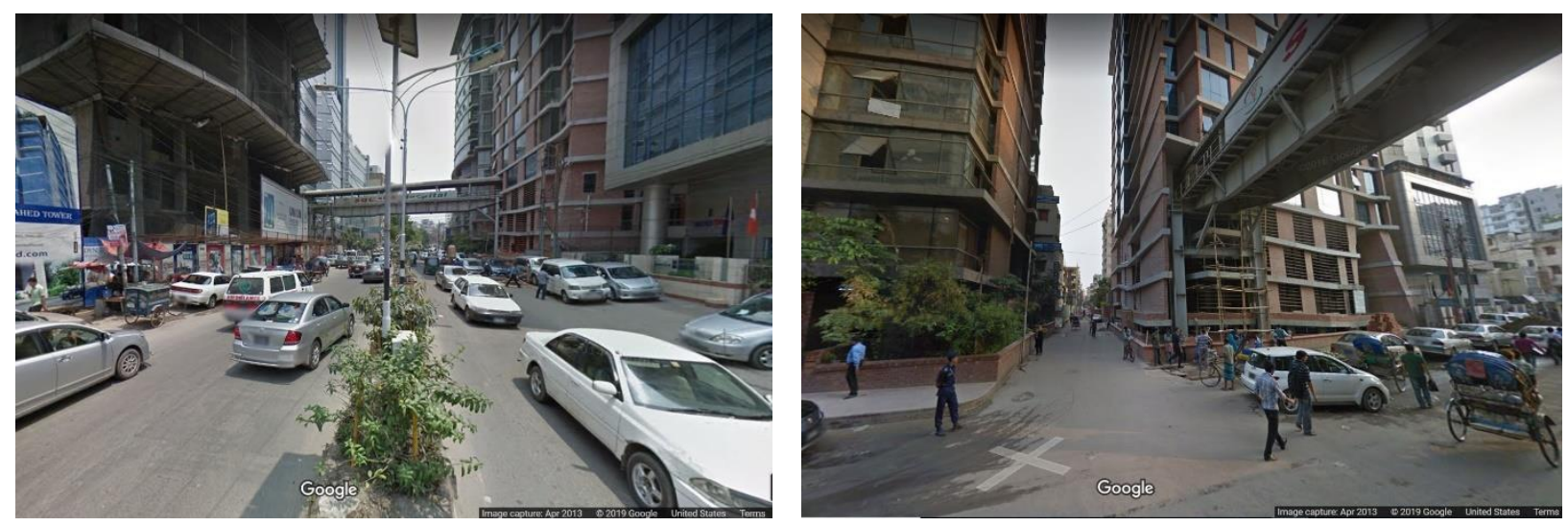

Figure 57: Images of Bridge area where two buildings are connected (source: google map)

There are some portions where one side has tall buildings and the other side has only one storied building. Type 3 is showing this scenario. At the place of type 3 (Figure 58 and 59), the road becomes wider than previous and here three lanes are observed. To create a connection with the local area, the road becomes wider here. The divider has the widest portion here. Usually, people 
use that portion for making roadside stall. People from different professional level come here to drink roadside tea and snacks.

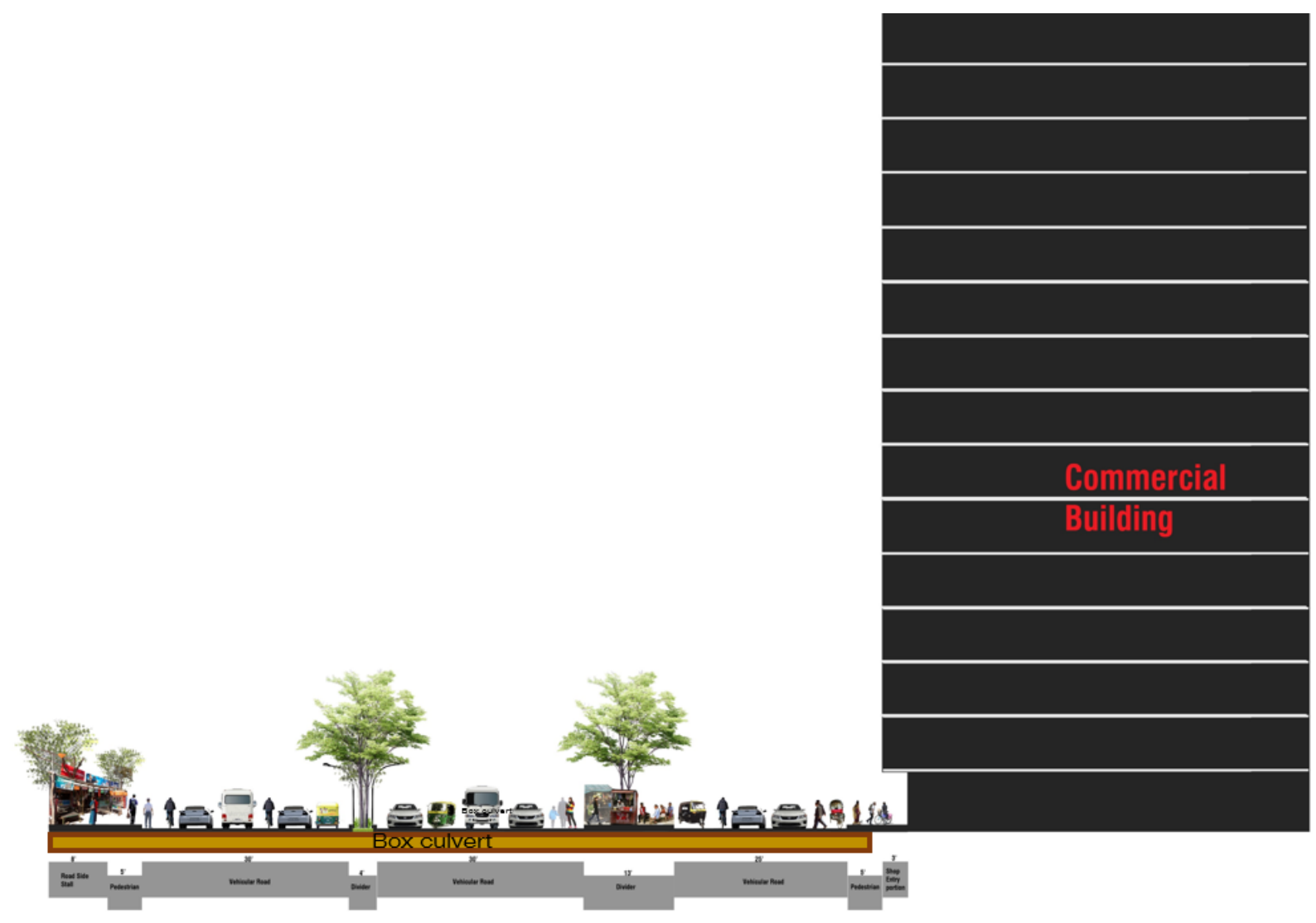

Figure 58: Showing situation for type 3.
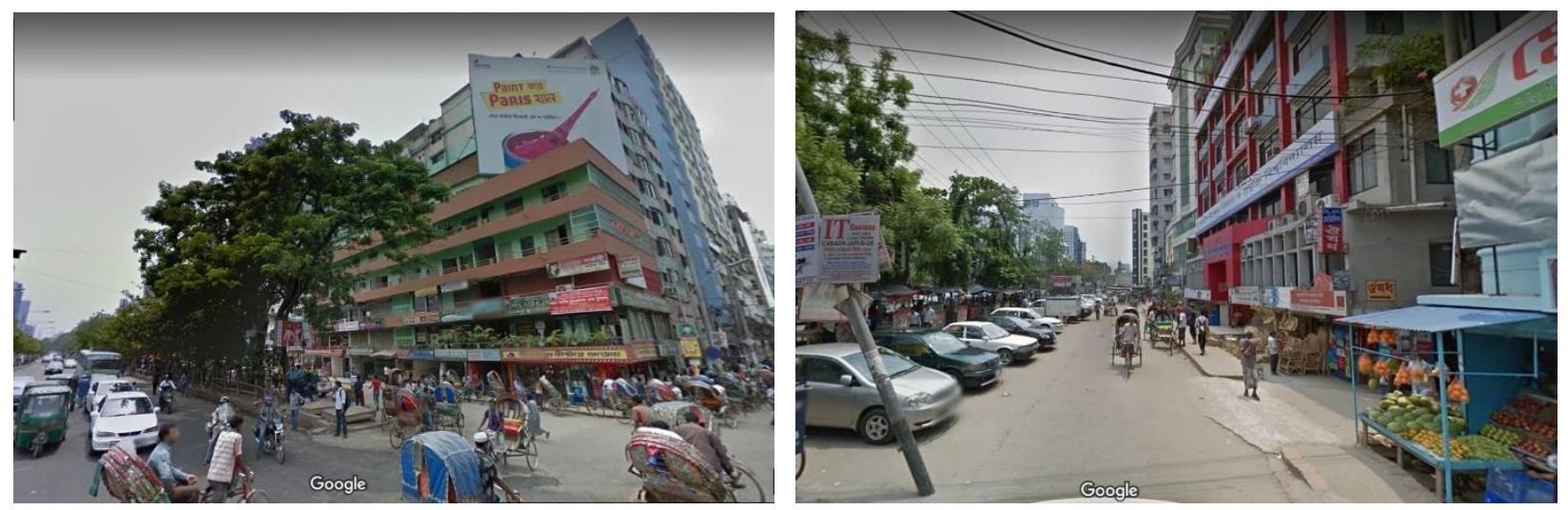

Figure 59: Images of road side shops and activity on road divider space (source: google map)

The scenario for type 4 (Figure 60 and 61) is for the both end of the road where it meets the two major roads. At that portion, the road has almost four lanes. The divider has several measurements at this portion. It is an important part as it is connected to major roads and it makes a square or circle. 


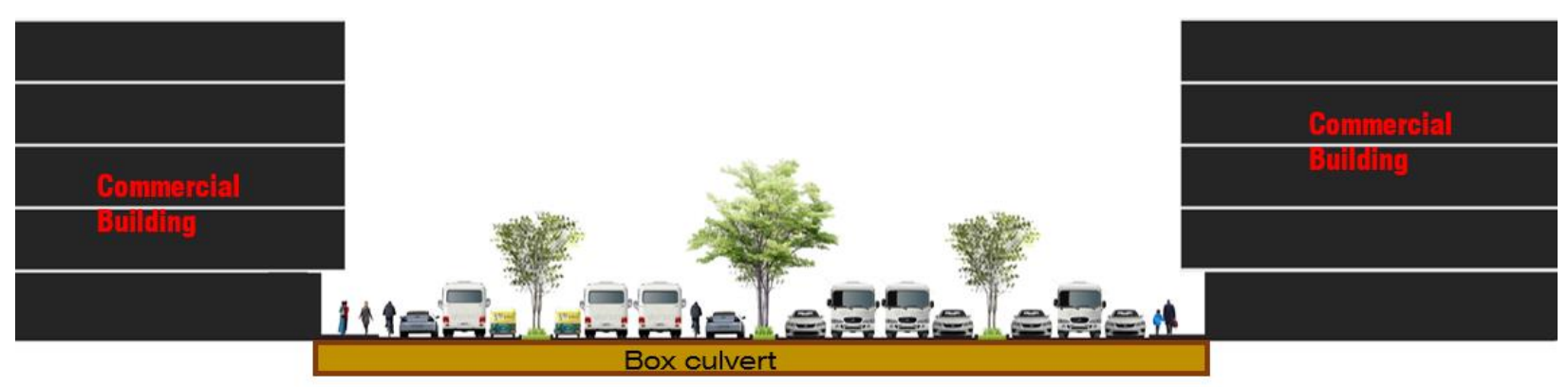

Figure 60: Showing situation for type 4.
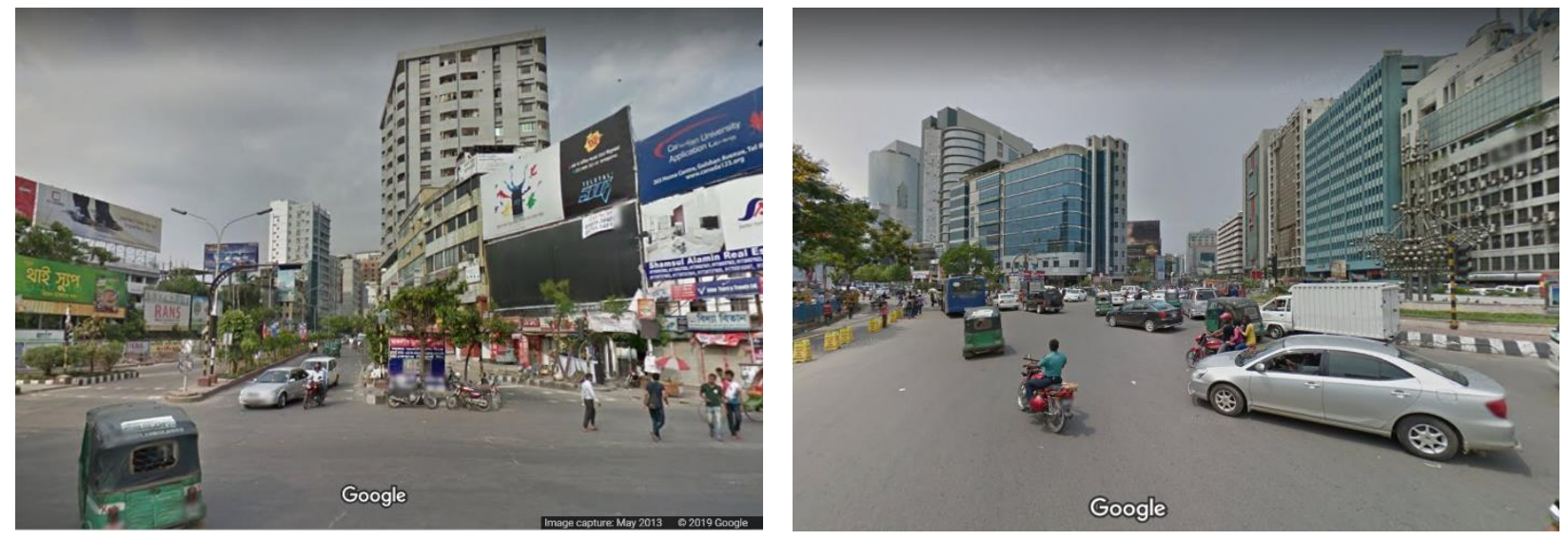

Figure 61: Images of west end and east end of the study area (source: google map)

\subsection{Historical background of the Study Area and present discussion}

Dhaka's Khals often translated as canals. Canals were the essential part of the drainage system of Dhaka city. Canals were also the transport corridor for Dhaka city. Figure 62 is showing how the canals connected each other to make the network for the natural drainage system.

Our study area was a part of this natural drainage system. Historically it is proved that the connecting road from Russel square and SAARC Fountain was the channel of lost river Norail of Dhaka city (Samakal, 2016). It connected two big canals. People used to dump their daily waster on this channel and blocked it. To prevent the dirty scenario, a culvert was made to cover this area. It was expected that; the water should go through the culvert. In reality, it only increases the hazard for the local people through casing waterlogging. 


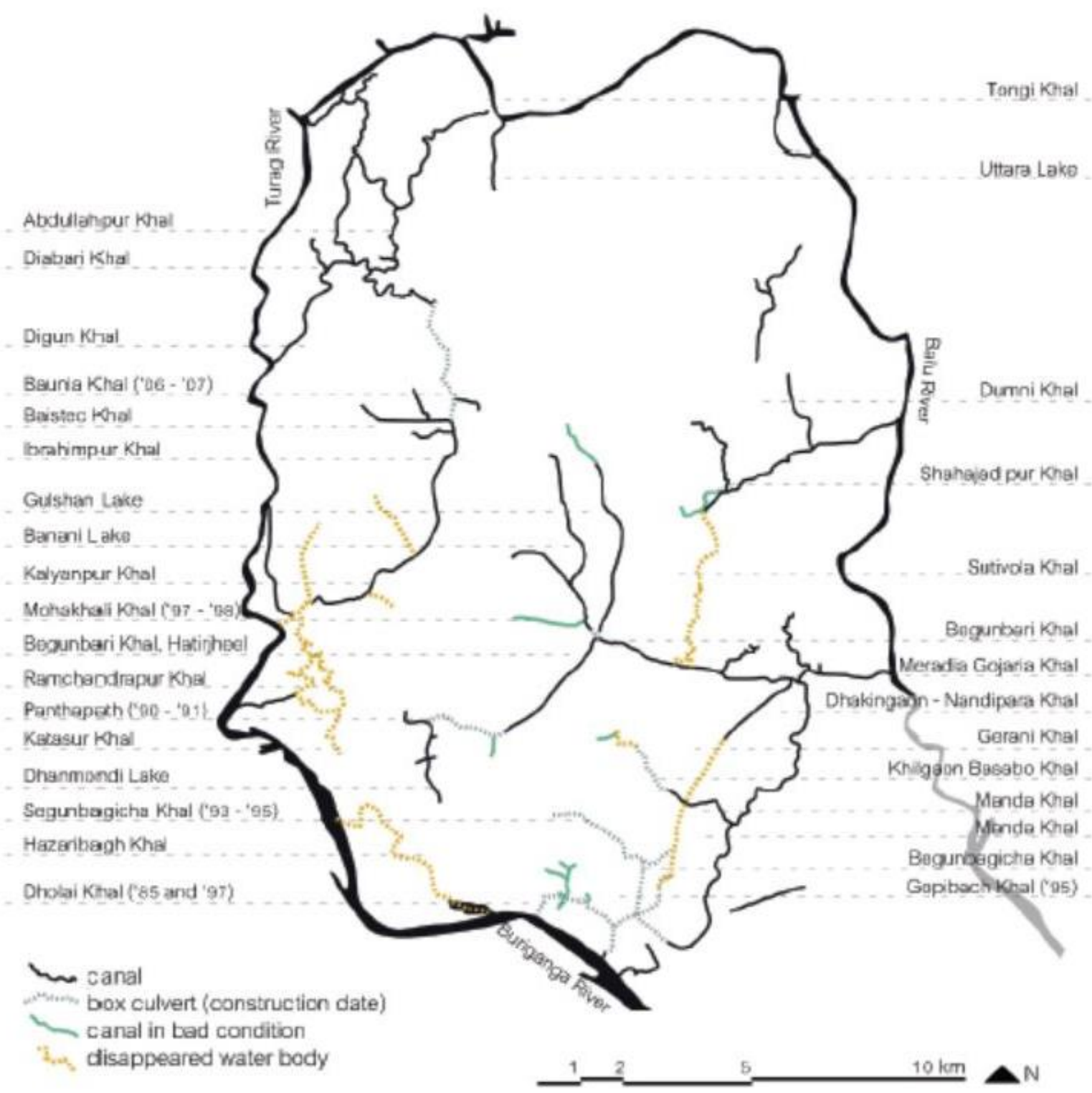

Figure 62: Dhaka's Khals from 1955 to 2009 (source: Peeters and Shannon)

These two maps are (Figure 62 and 63) made at the different time frame. From the maps, it is observed that the canal was there until 1990. The length of the box culvert is $1.5 \mathrm{~km}$. It starts from Russel Square and ends at the back side of Sonargaon Hotel (Prothom Alo, 2017). At 1993, the waterways were covered by a culvert to convert it as a vehicular road. 


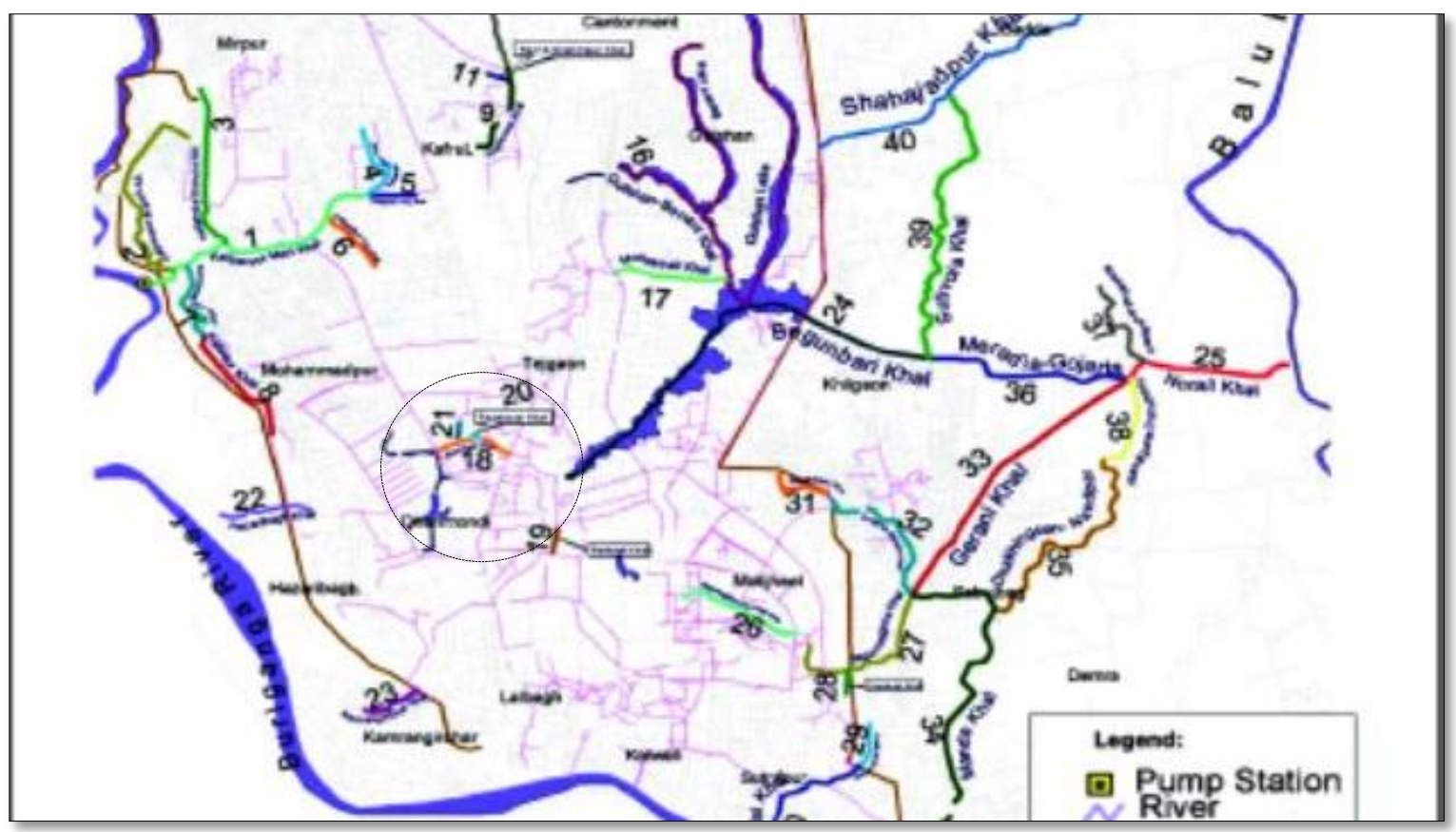

Figure 63: Map showing culvert condition at study area. (Ishtiaque et al. 2014)

Professionals from different fields especially urban planners and environmentalists gave a speech regarding open these box culverts throughout the Dhaka city (Prothom Alo, 2017). The culverts are filled up with waster material as it is hard to clean the inside of the culvert. So, water flow reduced almost $50 \%$ for having culvert in any area. After observing the worse situation of having culvert, no culvert was made after 2009 (Shamol Bangla Media Ltd, 2019).

According to Engineer Taksim A Khan, there are three main causes of waterlogging in Dhaka city. The first one is, there should be $12 \%$ water body of the whole area for any city, where Dhaka has only $2 \%$ water body of its area. The second one is $90 \%$ of the surface area of Dhaka is covered by impervious material. So, water cannot be absorbed by ground level and as a result, groundwater level is decreased. The third one is, low lands are filling with various types of infrastructure. So, water needs to be pumped up if any area faces waterlogging.

According to some professional engineers, the structure of the present culvert is not good in terms of flowing water. The present structures are a rectangular shape. If the structured was made in a circular shape, maybe it would be easier to clean the inside of the culvert.

Prime minister Sheikh Hasina also advised to open the box culvert and propose elevated express road for those places (Prothom Alo, 2017, The daily Janakantha, 2019). She also mentioned the waterlogging hazard as a top priority. She also said the government would re - excavate old canals in Dhaka and dig new ones to establish a better water management system for the country's largest city. The government is planning to form an independent task force to recover the encroached canals of Dhaka and ease the perpetual waterlogging crisis in the capital. 


\subsection{Infrastructure Study}

Different types of buildings are located here (Figure 64). The area is mostly occupied with mixeduse building. The mixed-used types vary from residence to bank, office, shop etc. There are two hospitals which are a very important structure for whole Dhaka city. One big commercial building which is called Bashundhara City Complex is located here. There are some educational institutions. Some portion is occupied with one storied shop. Some residential building is also observed here with the office portion. In terms of building typology, it was hard to make the decision to convert the road into a waterway. Specially for the patients, it would be very difficult to come

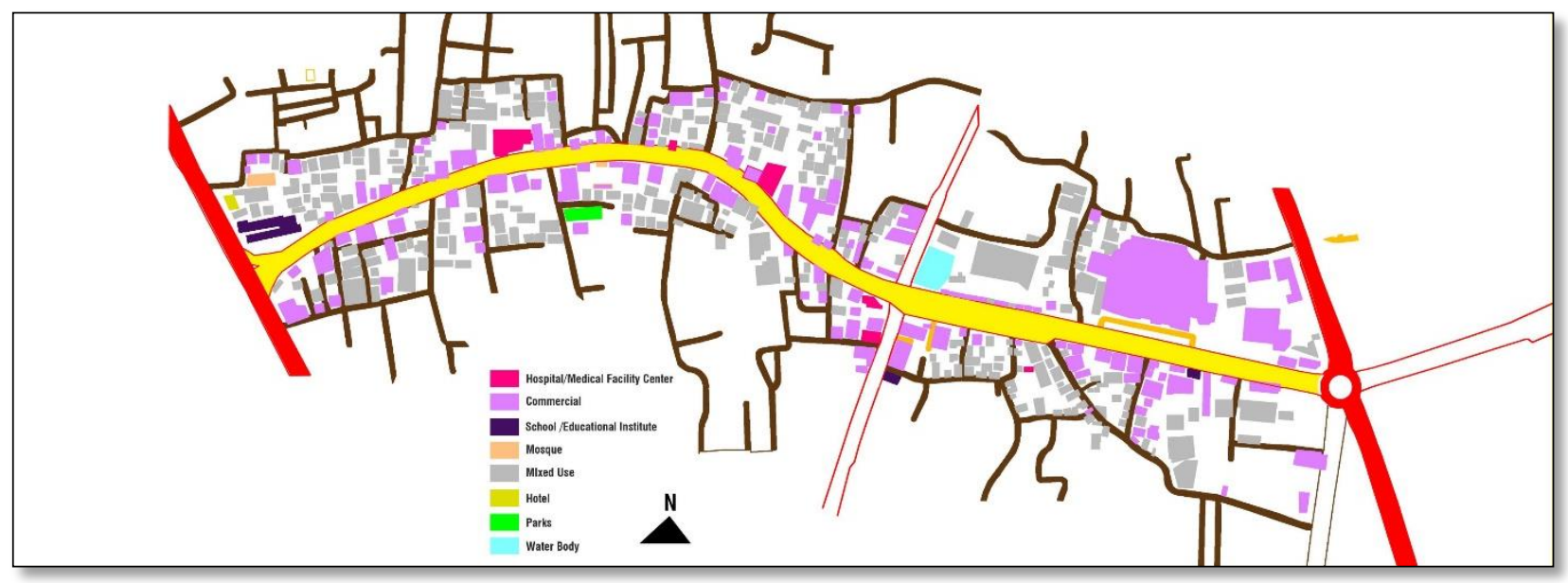

Figure 64: Existing Site Plan with Building Typology

to the hospital without any proper entry point from the main road. So, emergency vehicular access can be useful for the situation to entre to the building from the front door.

In terms of open space, the area is really occupied with impervious surface. No open space is found here, except one park and one water body. Spaces between buildings are not open to the ground surface, which is one of the causes to increase the inundation rate during monsoon time.

Two major roads are located here as the boundary of two ends at the north-south direction. It is observed that there are several tertiary roads from which most of the buildings have a backside entry. From observing the situation, it can be decided that an alternative route can be proposed by connecting the tertiary road to bring people to the buildings of this area.

\subsection{Road Connectivity Analysis}

Space syntax is used here to analysis the road network connection. It has been done in two ways. One is considering the all road network throughout the city and another is considering only major roads which are related to this area.

For the first case, (Figure 65) it is observed that, the portion from the western end to Green road 


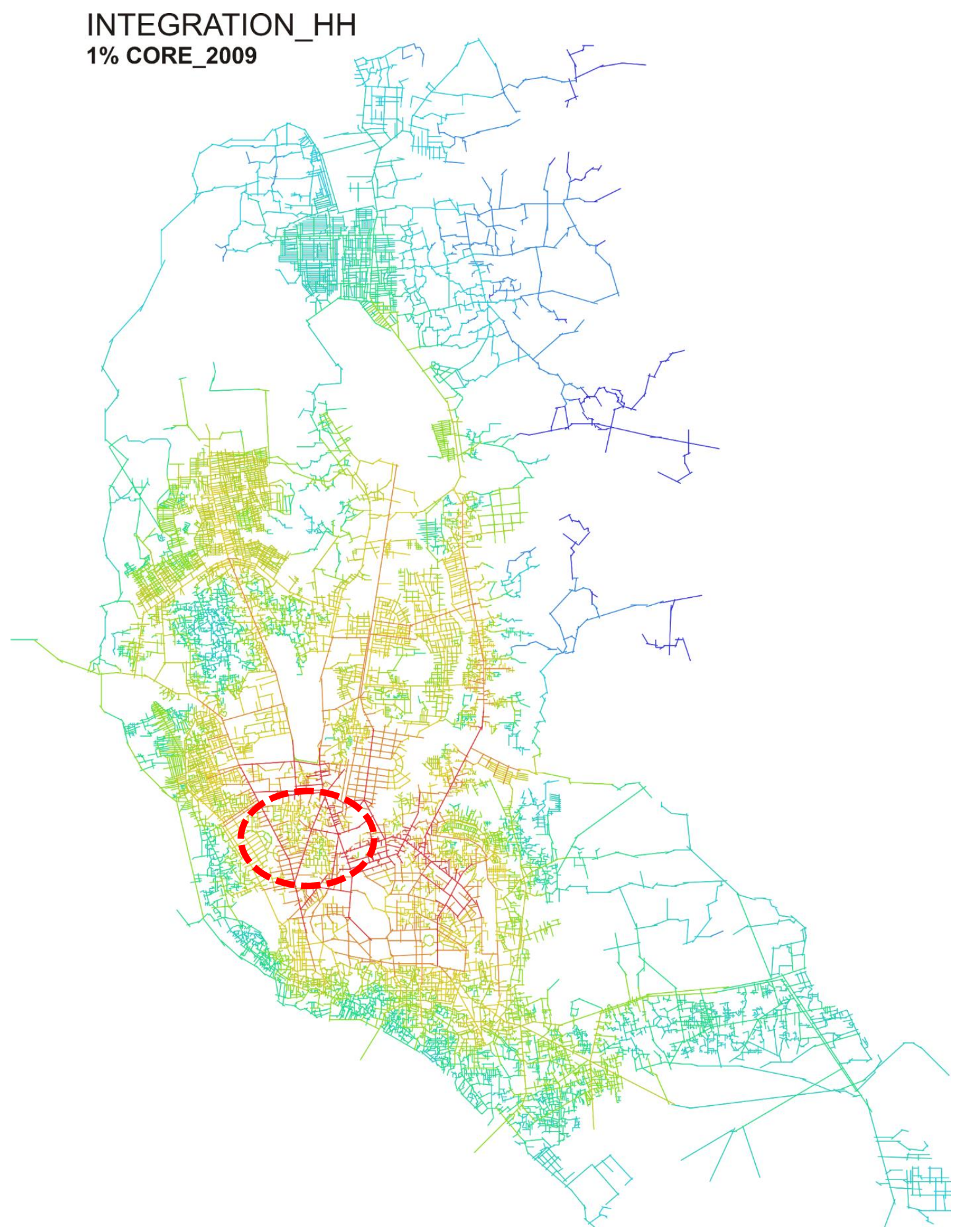

Figure 65: Road connectivity analysis throughout the city scale 
edge is not that much important in terms of connectivity purpose. The eastern portion which begins from Green road edge is very important.

For the second case (Figure 66), the road becomes very less important in terms of connectivity purpose. So, a decision can be made here, that an alternative road can be proposed at the northern portion of the study area.

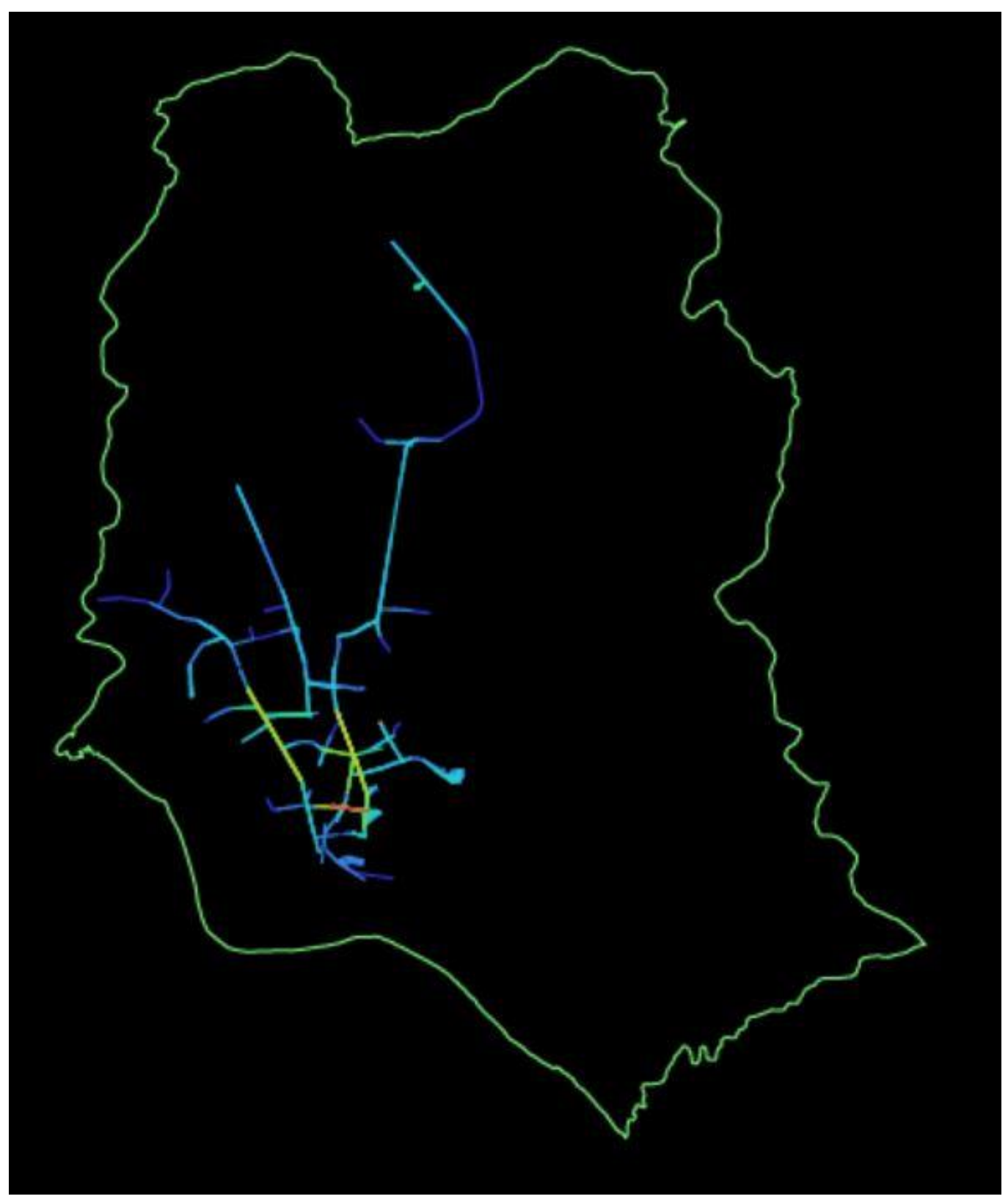

Figure 66: Road connectivity analysis only considering major roads which are connected with the study area. 


\subsection{Census Data}

The study area is located within five wards, such as; ward number 39, 40, 49, 50 and 51. According to the 2011 census data of Bangladesh, approximately thirty thousand people live in this area. Every day more than one hundred thousand people come here for doing their job or to take services or to visit this area. Population density of this area is more than twenty thousand per square kilometers.

\subsection{Finding Catchment Area}

It is important to know about the volume of water what is needed to work with for the study purpose. As this area is having the problem of inundation, that means this area is lower than the surrounding area. So, the area from where water comes to this area due to surface runoff is called catchment area. Here, hydrology tools from ArcMap are used to generate the catchment area for the Panthapath road area. At first, a pour point is fixed hereafter analyzing the elevation

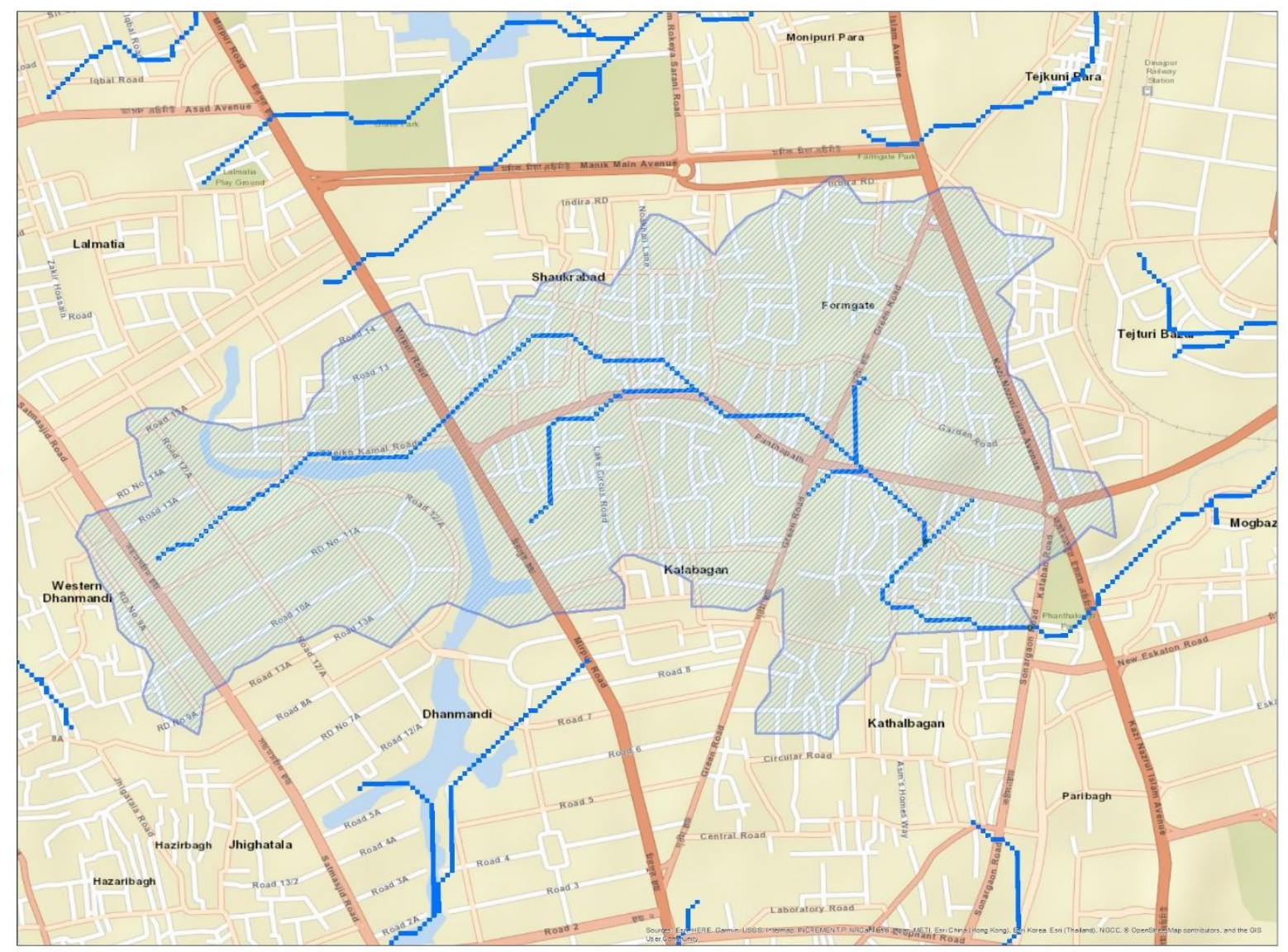

Legend

Catchment Area

Water Flow Direction line

Figure 67: Catchment area for study area 
Model of this area. Pour point is the lowest point of the study area. While fixing the pour point, it is observed that the water comes from the western part is going to the eastern part according to the flow direction analysis. That means, after creating the water channel, we need to consider that water will come from Dhanmondi lake to this new channel. Maybe, in the near future, this finding will create a new opportunity to make a new decision for the overall city plan.

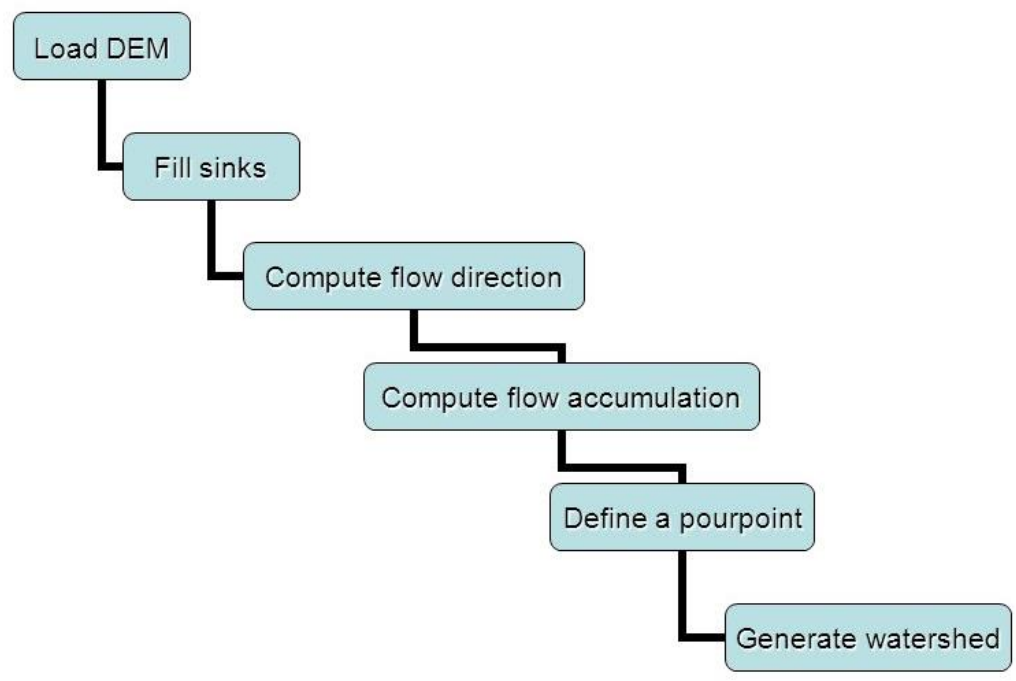

Figure 68: ArcGIS flow diagram for generating catchment area (source: ArcGIS online resource)

\subsection{Catchment area condition}

The catchment area analysis has been done in ArcGIS, which shows the absence of the lost water body that connected the Dhanmondi Lake and Hatirjeel-Bagunbari water channel once. The catchment area is quite large as the topography is almost flat. The area of the catchment area is 2.4 sq. km. For this huge catchment area, the only retaining water body is the Dhanmondi lake, situated at the west side. Unfortunately, as there is no such water retention area like Dhanmondi lake nearby, the water of this huge area remains stagnated during any rainfall.

Figure 69 is presenting the building typology for the catchment area. The number of the building of this area is six thousand three hundred and eighty (6380). The area occupied by the building structures is almost 1 sq. $\mathrm{km}$. The densely populated building area increases the impervious surface. There are some educational institutions here. The waterlogging is causing a problem for students as well as other workers. So, a huge loss is observed here, in the working sector and in the economic sector of the city.

There are some small water bodies observed through analysis. These water bodies cannot be observed from the roadside portion. The area of water bodies is only $0.1 \mathrm{sq}$. $\mathrm{km}$., which is very small in terms of the catchment area. 
The road structure covers $0.3 \mathrm{sq} . \mathrm{km}$ and pave area only covers $0.05 \mathrm{sq} . \mathrm{km}$. There is a man-made drainage system which does not even cover $0.1 \mathrm{sq} . \mathrm{km}$. It is only $0.0036 \mathrm{sq} . \mathrm{km}$. and the depth of the drainage system is from $1 \mathrm{ft}$ to $2 \mathrm{ft}$. So, the drainage system is very negligible to calculate the volume of surface runoff in terms of the whole area. For having less amount of drainage system, the water cannot flow out quickly during rainfall.

The catchment area is located within seven ward of Dhaka city. So, according to 2011 census data, more than three hundred thousand people lives here. So, this huge number of people suffers for water stagnation situation during rail fall.

Except for road network, there are other infrastructures like power installation, sewerage line, electric line and lines for gas and water supply (Figure 70 and 71). The power installation follows the road network.

Gas line and sewerage line follows the tertiary road network. The electric line follows the edge of the major roads and secondary roads. There are street lights on the street. The waterlogging causes huge risk in terms of electrocution due to the presence of high voltage caring wires both on the ground level and above.

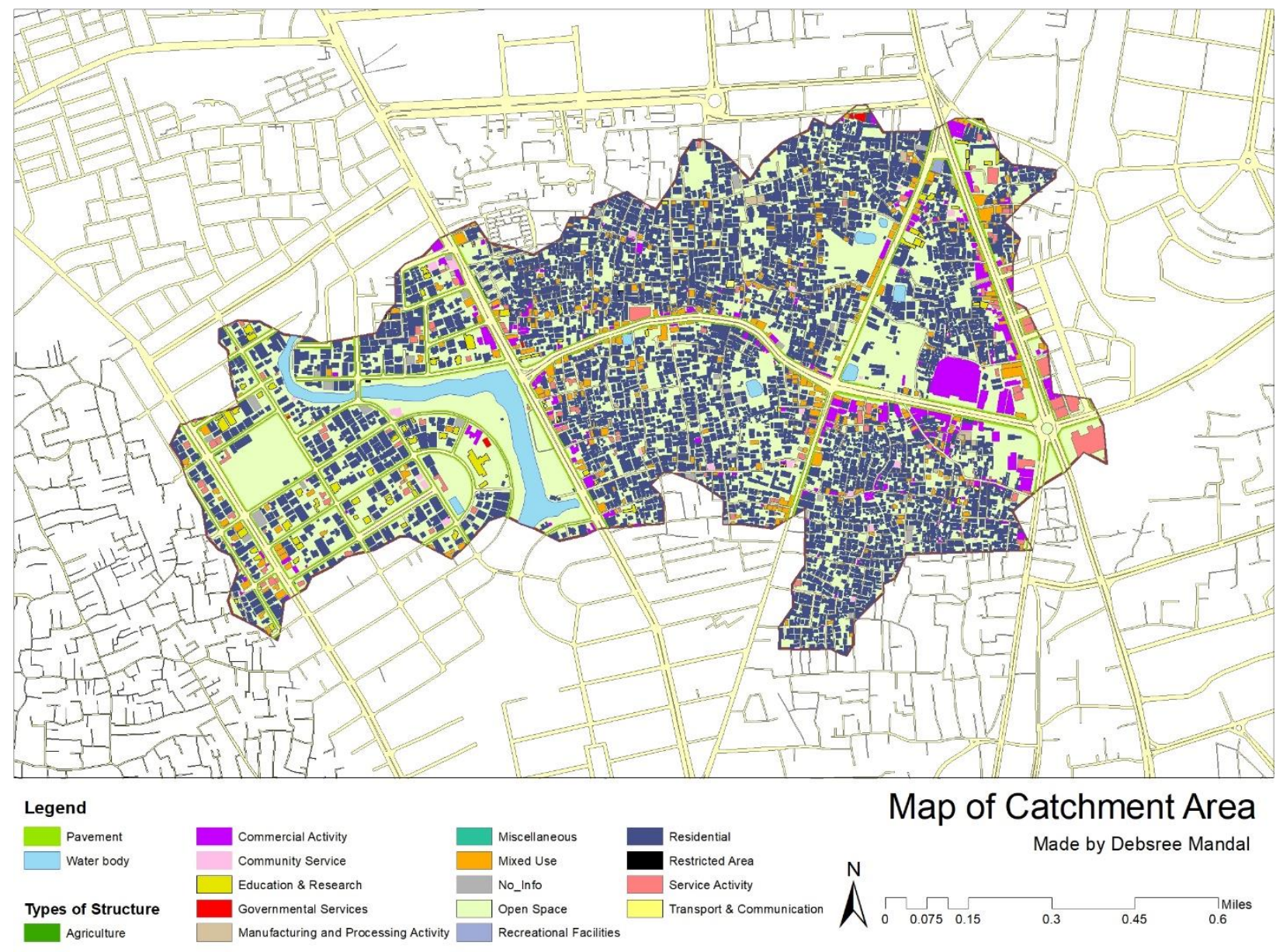

Figure 69: Landcover map with Building typology 


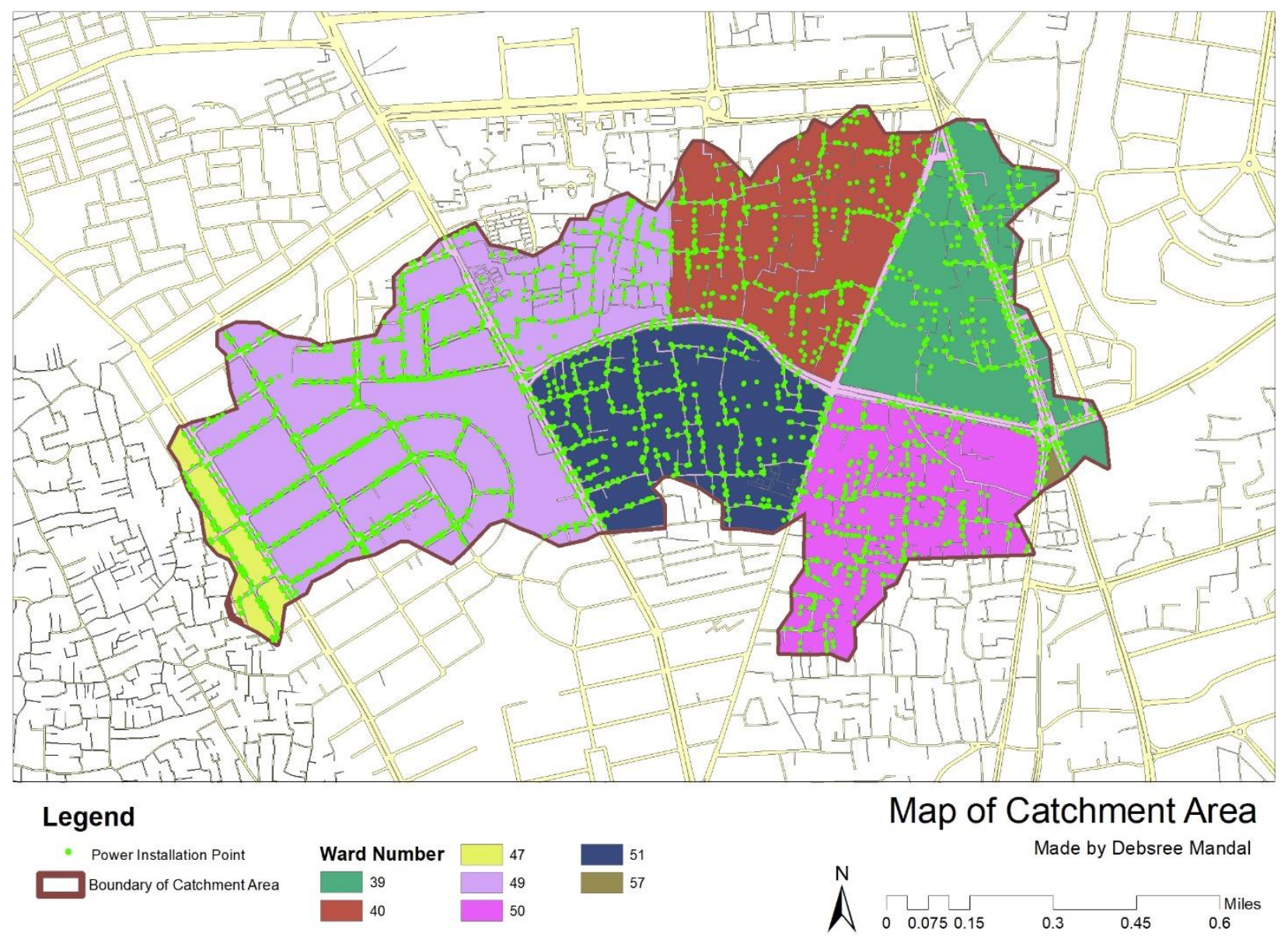

Figure 70: Map showing power installation points and wards

After proposing the waterway, the electric lights should be replaced on the lakeside pedestrian portion. The power installation points are needed to be replaced in a safer place. The gas line and sewerage line are needed to be redesigned for this area. Plumbing engineers and electrical engineers are needed to work here to solve the problem for the study area with the design farm.

Considering the problems and taking account the number of occupants, it is very important to address the problem which is currently facing by the people of this community. As a solution, by providing water retaining option, the problem of inundation can be controlled to a manageable extent. Small water retention area will not work here, and the space characteristics do not allow to make several ponds here. So, the only option is to make a large water retention area.

From historical data, it is observed that this area did not have such inundation problem due to the presence of a canal connecting water bodies at both east and west end of the catchment area. By bringing back that lost waterway connection, it will drastically improve the overall connectivity of water flow. The proposed water body will not only work as a water retention area, but will help to channel out water, if a new connection can be introduced at the east portion also.

This study is showing that it is not only a work for an urban planner or a landscape architect, but expertise from various fields are also needed to be gathered here to make a good strategic plan to implement the proposal successfully. 


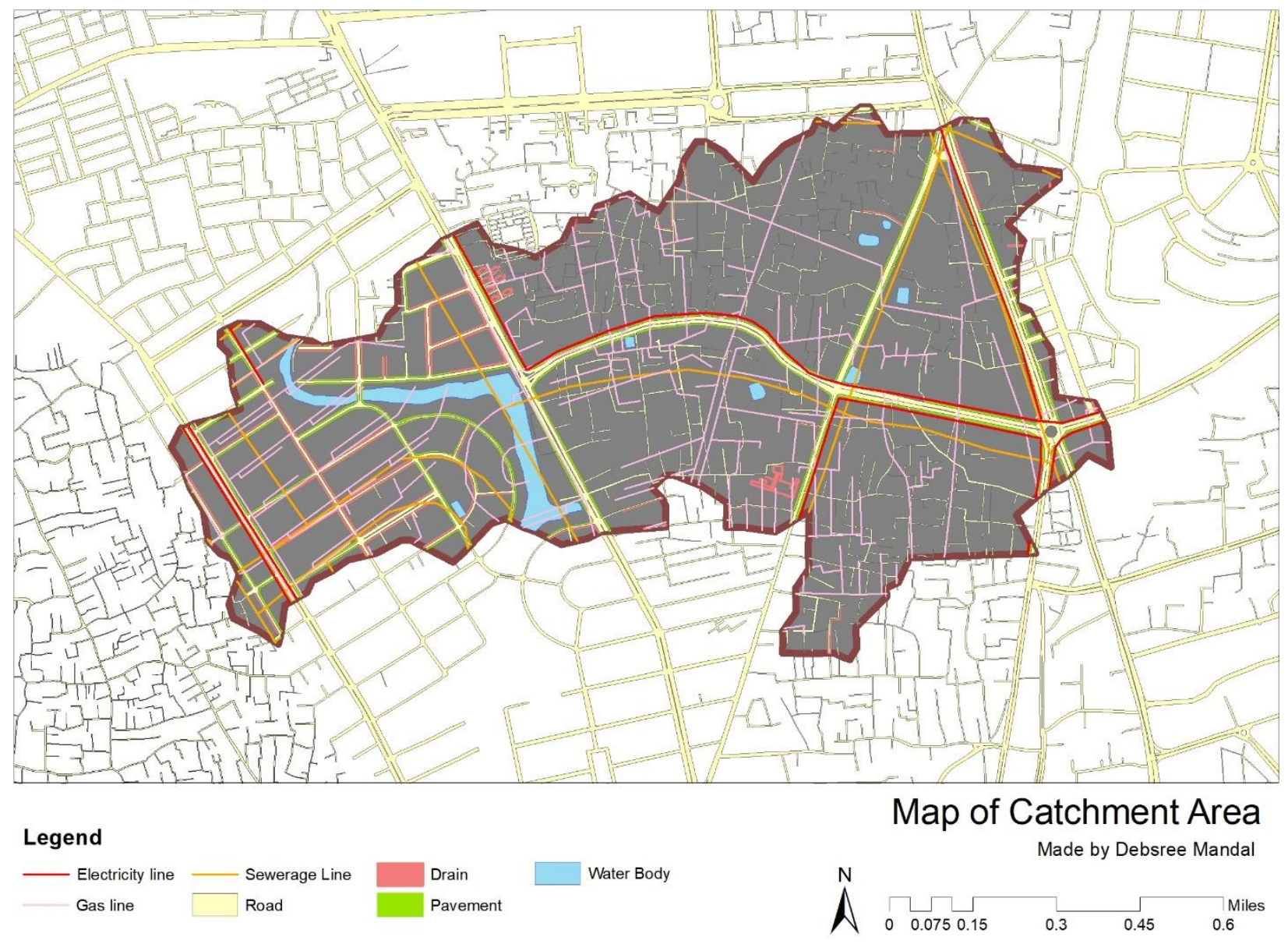

Figure 71: Map showing utilities points

\subsection{Surface Runoff volume calculation}

To calculate surface runoff everyday rainfall data is important. Figure 72 is presenting the everyday rainfall data from 1971 to 2015 for Dhaka city. Here, the highest rainfall data is used for the calculation part. There are not that many other surfaces like open area, fields or water body. The ArcGIS analysis shows that the catchment area is 2.4 sq. $\mathrm{km}$ and other surfaces are neglected here as the previous surface portion is small. It is not even $0.1 \mathrm{sq}$. $\mathrm{km}$. The building area can give an impact if, rainwater collection methods are proposed here. A roof garden can be a useful thing for this purpose. The area has some drainage system also.

So, considering every aspect, it can be said that $90 \%$ of the catchment area should be taken to calculate the surface runoff volume. One thing should be mentioned here that, the study does not cover to find out the typology of rainfall for Dhaka city. So, Tr-55 software cannot be used here. A website is found here for the calculation part. It is for having a general idea to calculate the water 
volume. If the proper calculation process is used, the volume should be reduced. It is the part of hydrological engineering, which is not discovered fully here.

The average rainfall is considered here $340 \mathrm{~mm}$. It was the highest rainfall taken from the rainfall data. After placing the rainfall data and area measurement of catchment area which is 2.3 sq.km, the water volume is found 782000 cubic meters from the website of calctool.org. This amount of water volume is considered here to design the lake area.

\section{Rainfall}

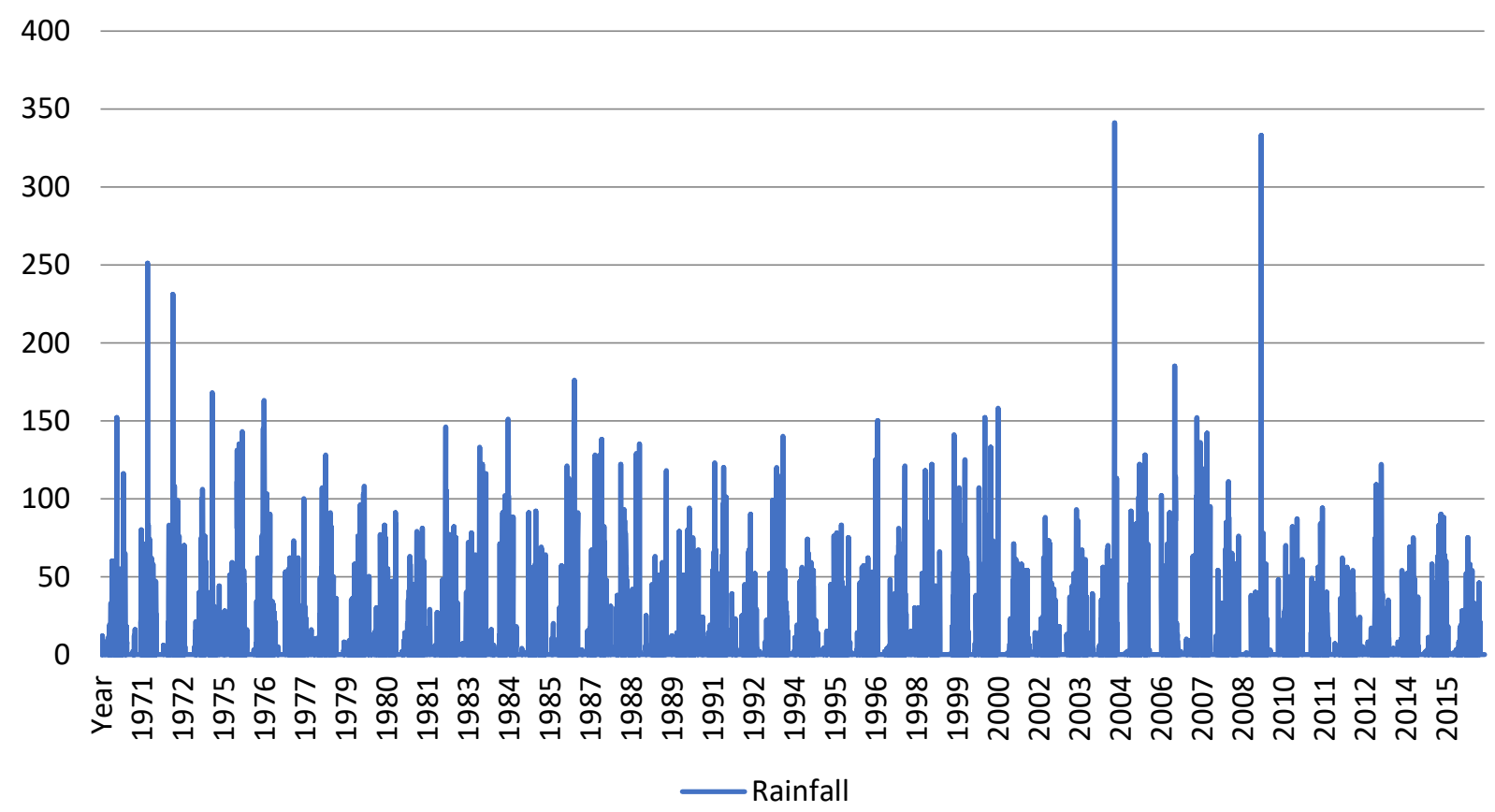

Figure 72: Daily Rainfall Data of Dhaka

After calculating the water volume, some design decisions are made here. Except proposing the waterway only, some portion of the study area is designed with previous materials so that, rainfall water can be absorbed. The bioswale portion is proposed here to collect rainwater. The new stormwater drainage system is proposed here under the permeable surface. measurement of permeable surface portion.

After calculating every aspect, it can be said that $20 \%$ of total surface runoff can be reduced by providing permeable surface and bioswale portion. Detail hydrological engineering study is needed to figure out the exact amount. No doubt, the reduced amount surface runoff will be increased. 


\section{CHAPTER 4: CASE STUDIES}

\subsection{Pymmes Brook, Edmonton, London}

Pymmes Brook is a minor tributary of the River Lee (Figure 73). The brook rises in Hadley Wood and flows in a south-easterly direction to merge with the River Lee Navigation at Tottenham. It passes through East Barnet, New Southgate, Arnos Grove, Palmers Green and Edmonton.

This project was generated to reduce the flood risk. The Pymmes Brook catchment is vulnerable due to flood events. In the past the Pymmes Brook was culverted. After inspection, it is revealed that collapsing the culvert can cause damage to 1,500 properties during major flooding. So, during 2005/06 the Environment Agency strengthened the channel walls of a section of the Pymmes Brook and remove the roof of the culvert. Thus, culvert removal reduces flood risk than culvert collapse.

This restoration encourages to remove the existing culvert and open up river channels where it is necessary and possible. So, more wildlife is invited here. The project cost was $£ 1.9$ million as part of the total culvert renovations. $£ 25,000$ is spent on local environmental improvements.
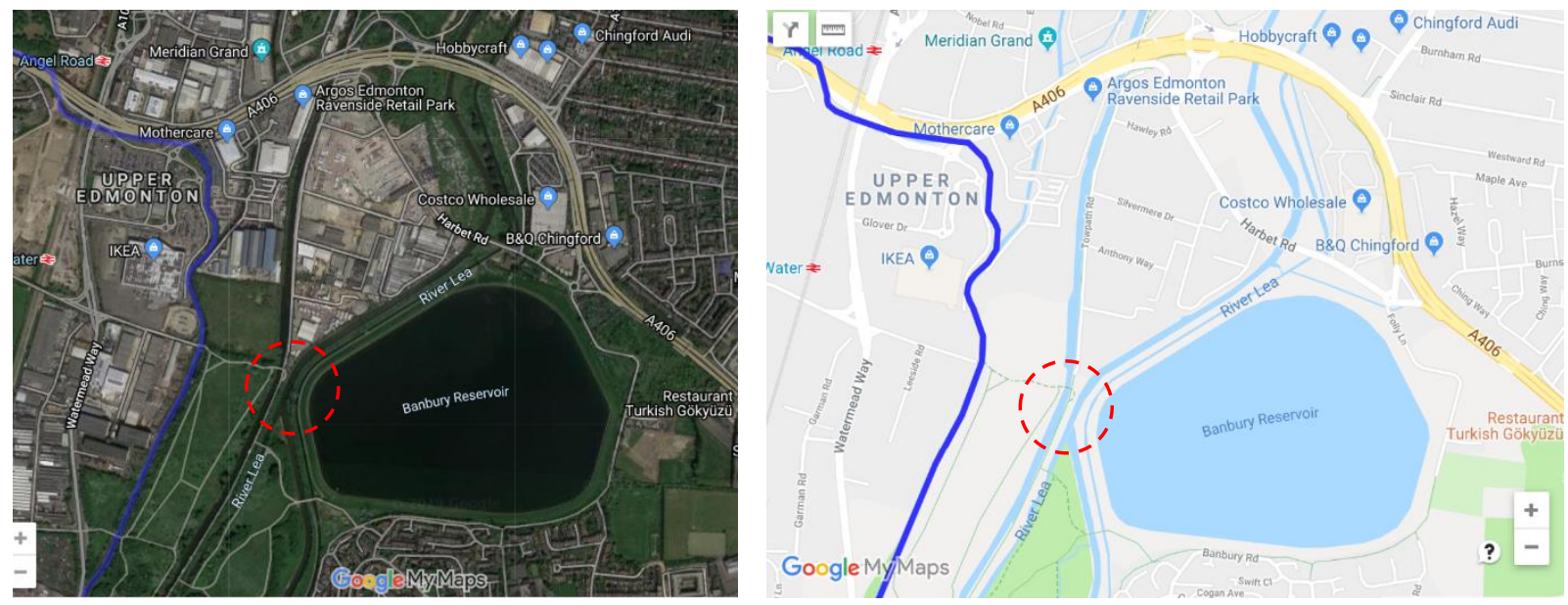

Figure 73: Location Map Culvert Area
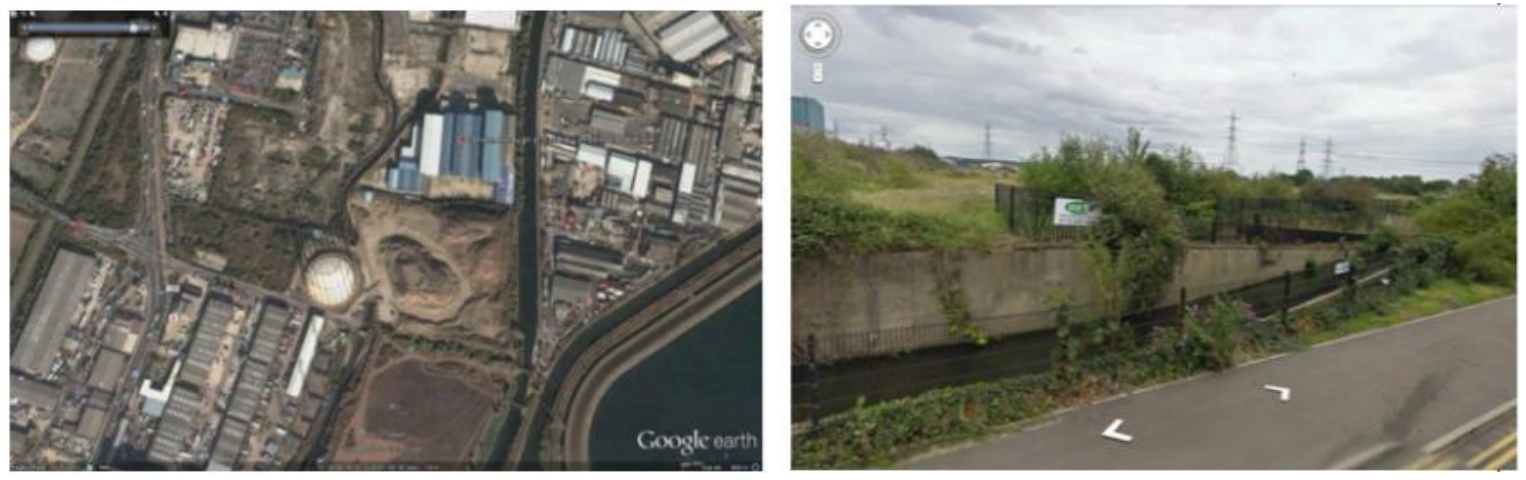

Figure74: Before image of de-culverting and after image of de-culverting 


\subsection{River Quaggy at Sutcliffe Park}

Project location: Eltham, South East London

River: Quaggy

London Borough: Greenwich

Project end date: 2003

Length: Approximately 500m

Upstream grid reference: TQ411748

Partners: Environment Agency, Quaggy Waterways Action

Group, Breheny Engineering, Greenwich Council

The River Quaggy at Sutcliffe Park was lost underground in a culvert for years. During only flood time, the local people can understand that there was a river. So, it is decided to restore the river by combining flood risk management which is beneficial for the local community. The main objective was to provide additional flood storage area in the form of ponds and lakes, while creating open space for people. Figure 76 and 77 are showing the condition of before and after the design was implemented. Figure 78 is showing the space for Open water to manage flood risk and provide access to nature.

The design elements are a new low flow meandering channel throughout the parking area, a sluice to regulate the water flow, lowering the park level to make storage for maximum 85,000 cubic meters of flood water, a network of broad walks, pathways and viewing points to encourage the access of people and wildlife.

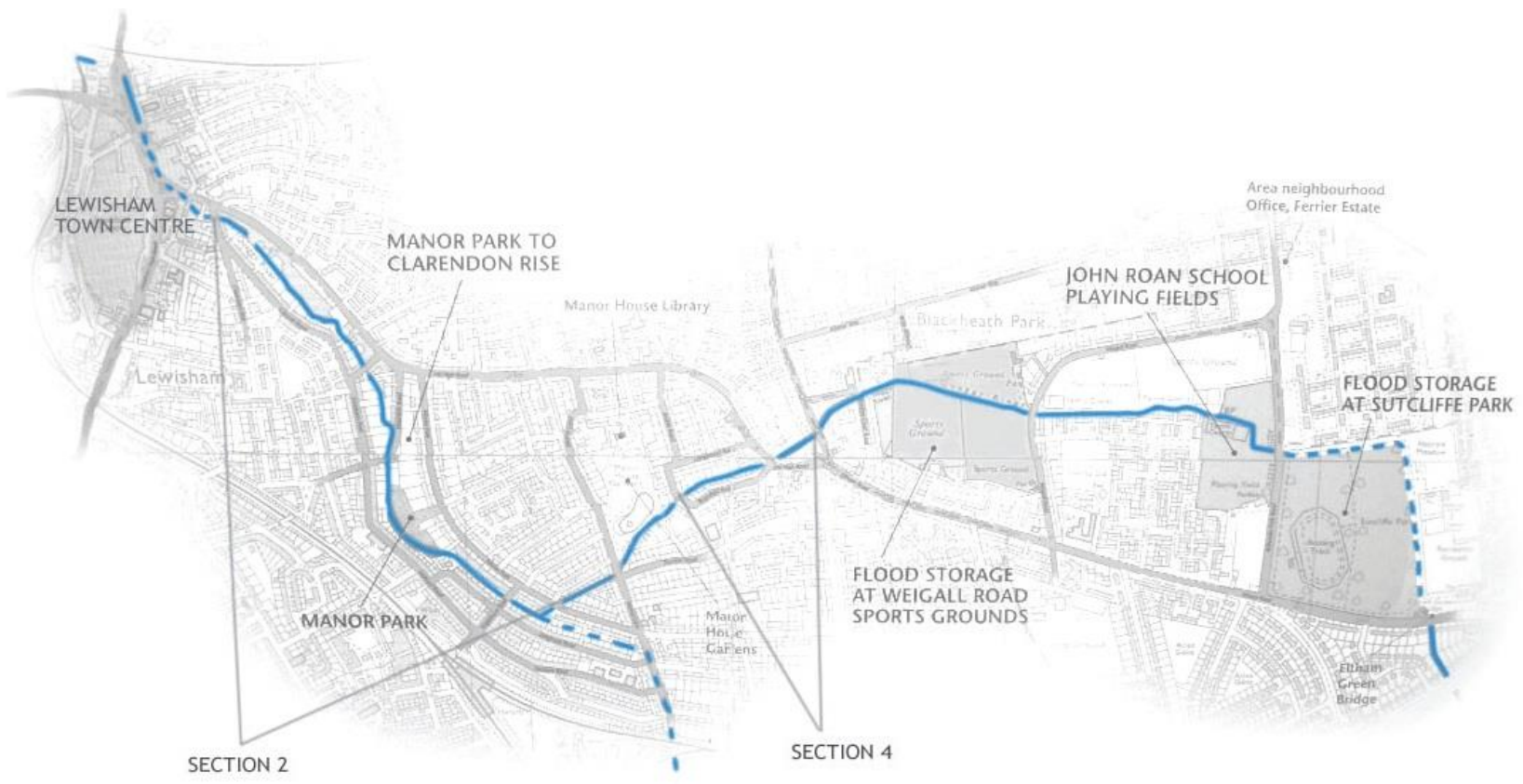

Figure 75: Showing river network (source: Case study: Sutcliffe Park, 2019) 


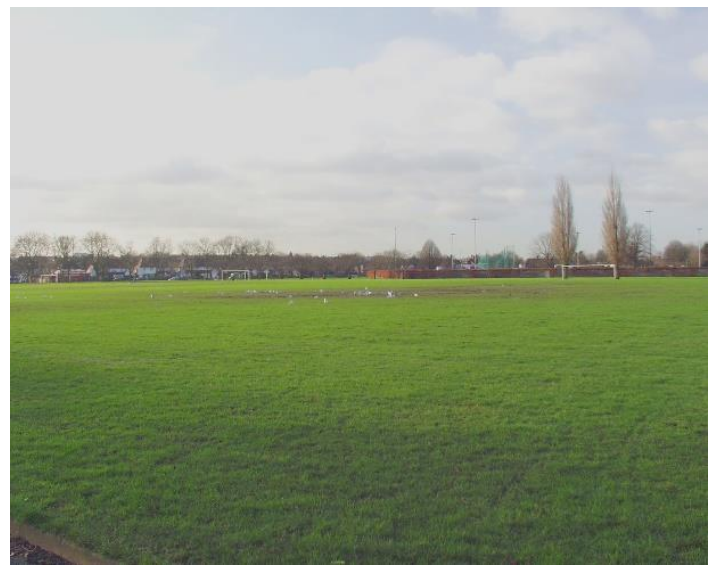

Figure 76: Before image of Sutcliffe park (source: Case study: Sutcliffe Park, 2019)

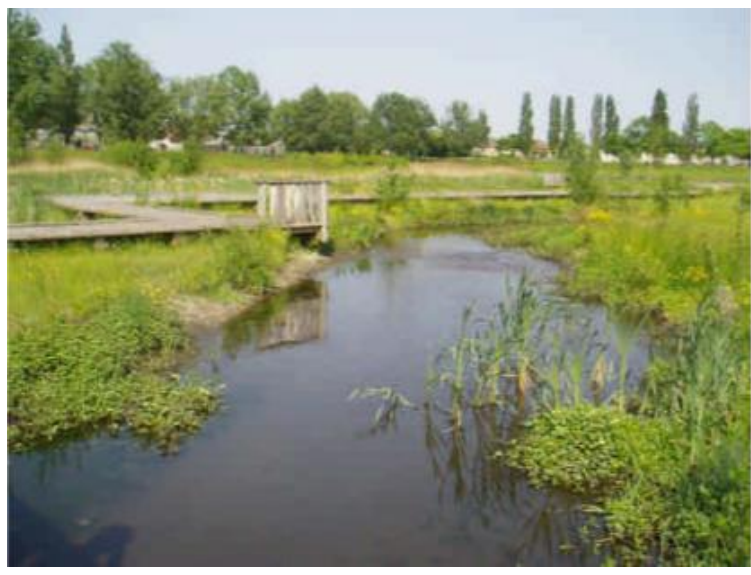

Figure 77: After image of Sutcliffe park (source: Case study: Sutcliffe Park, 2019)

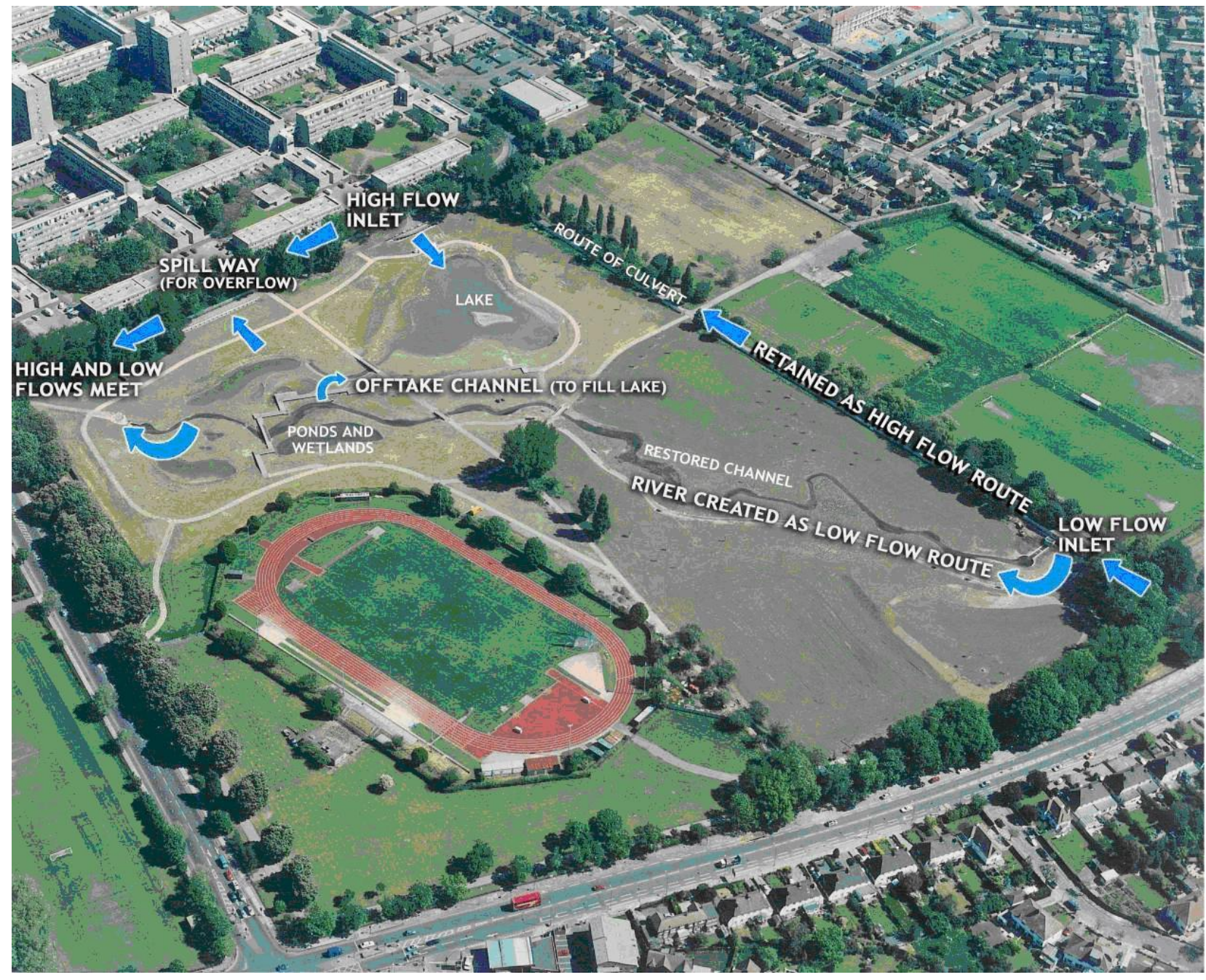

Figure78: Sutcliffe Park Flood defense aspects (source: Case study: Sutcliffe Park, 2019) 


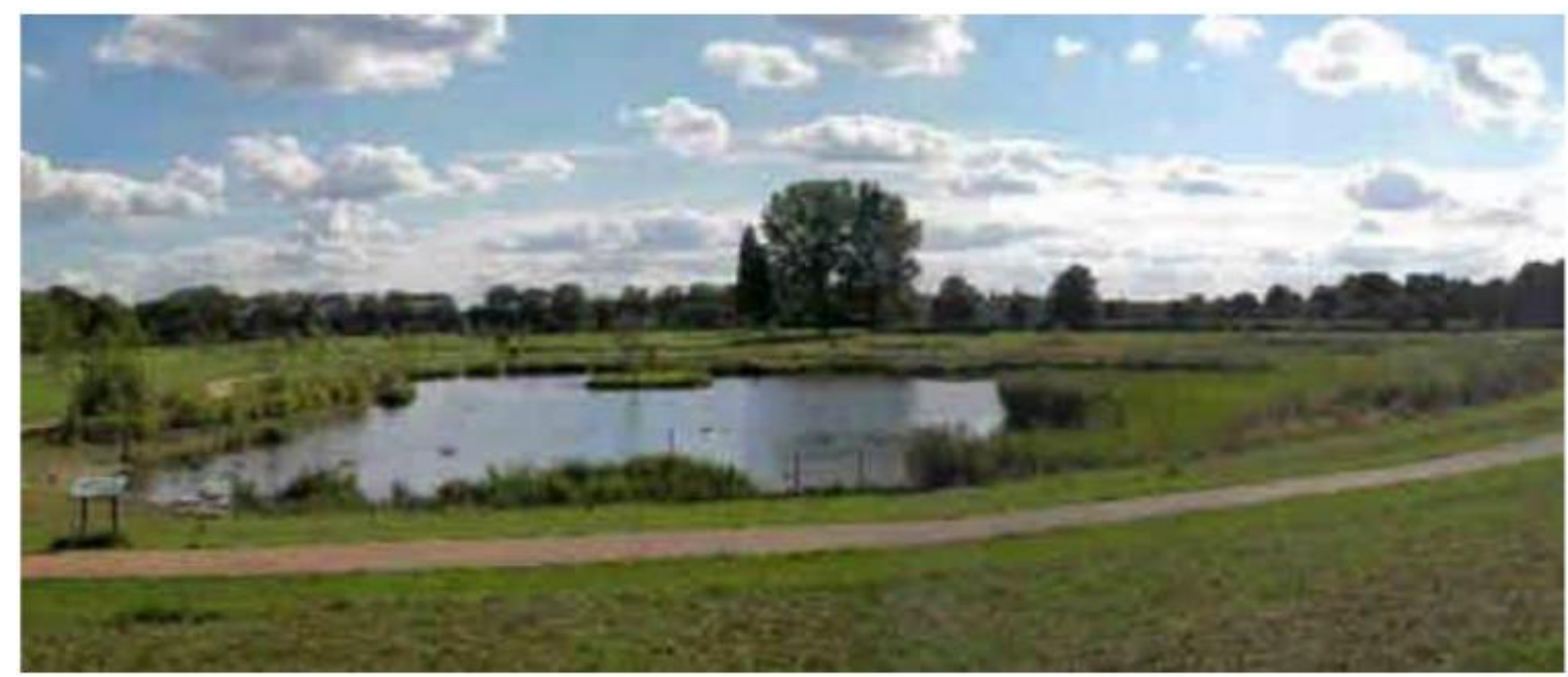

Figure 79: Open water providing space to manage flood risk and provide access to nature (source; River Quaggy at Sutcliffe Park, 2008)

\subsection{Cheong Gye Cheon Restoration Project}

Location: Cheonggyecheon

stream, Seoul, South Korea

Length: $5.8 \mathrm{~km}$

Cost: US \$280million

Dates: 2000-2005

Delivered through: Government funded, multi-partner project to deliver large-scale urban regeneration.

Partners: Cheonggyecheon Restoration Centre, Seoul Development Institute, Cheonggyecheon Restoration Citizens Committee, Seoul Metropolitan Government.
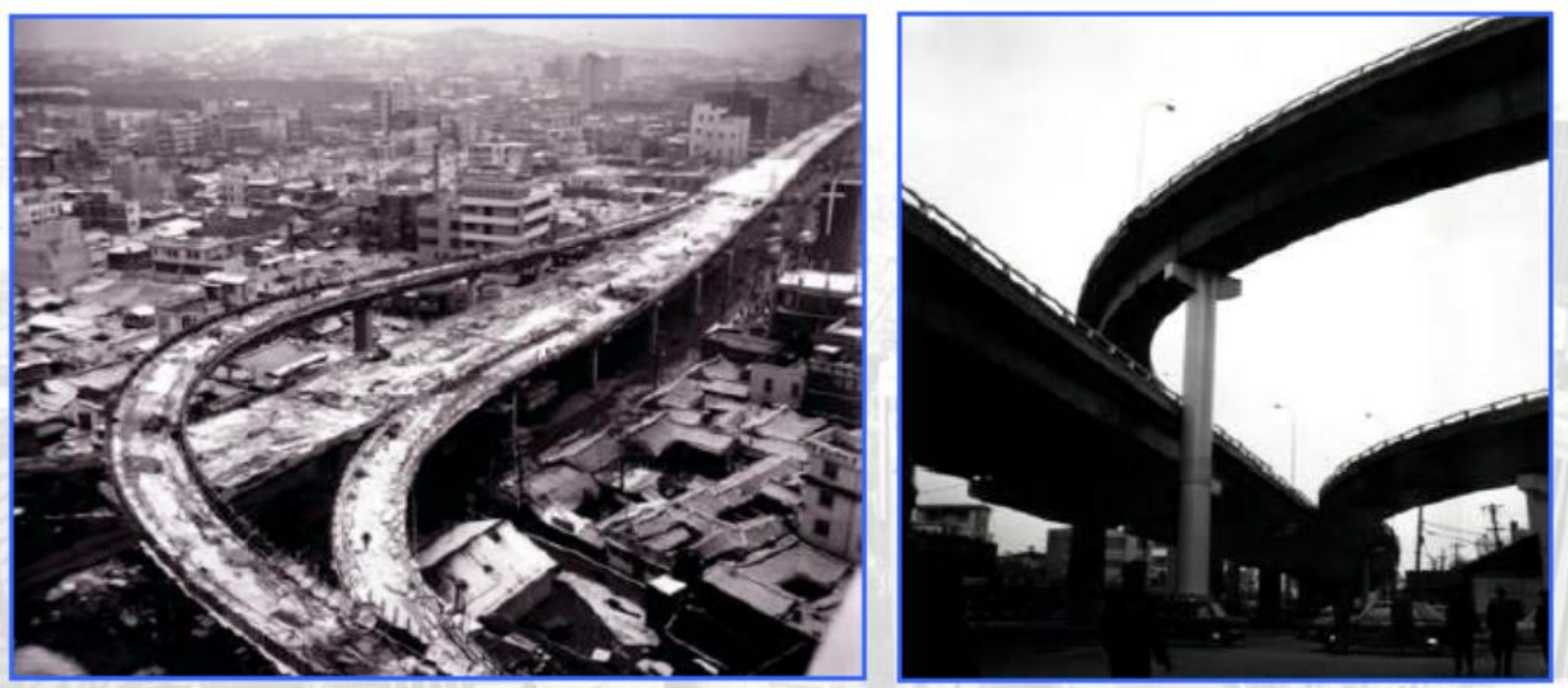

Figure 80: Cheonggye Highway (1967 1971) (source: Cheong Gye Cheon Restoration Project, 2006) 
The is one of the most expensive river restoration projects in the world. In the early $20 \mathrm{~s}$, the area faced sanitation problem. So, the solution was to culvert the river area and buried underneath a 12lane highway.
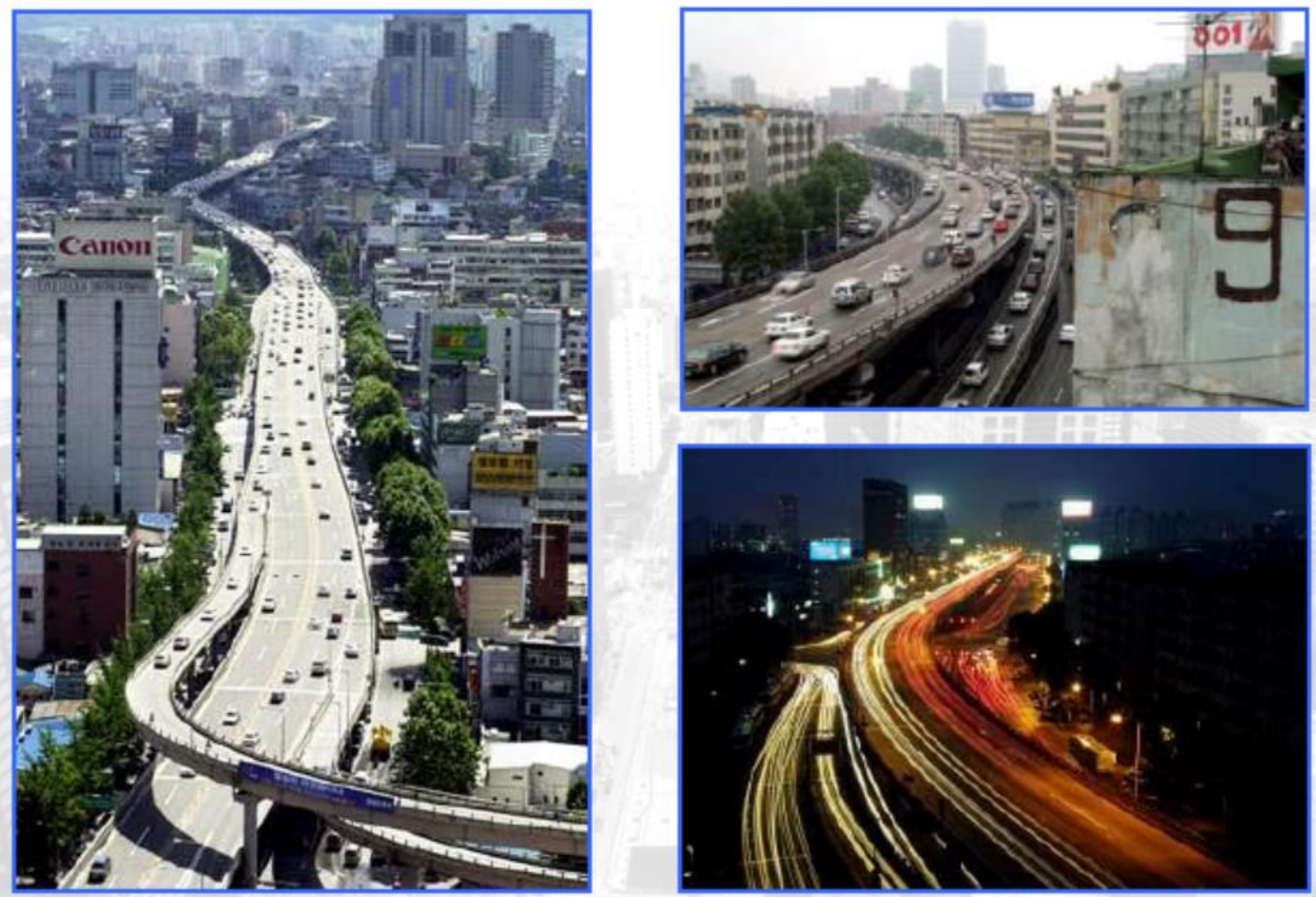

Figure 81: Cheonggye Highway in 1990s (source: Cheong Gye Cheon Restoration Project, 2006)

After the Cheonggye Expressway started CBD redevelopment stopped, business headquarters were moved to Gangnam, industries in CBD were lost competitiveness. The area also faced a safety problem due to heavy load on the highway (Figure 82).
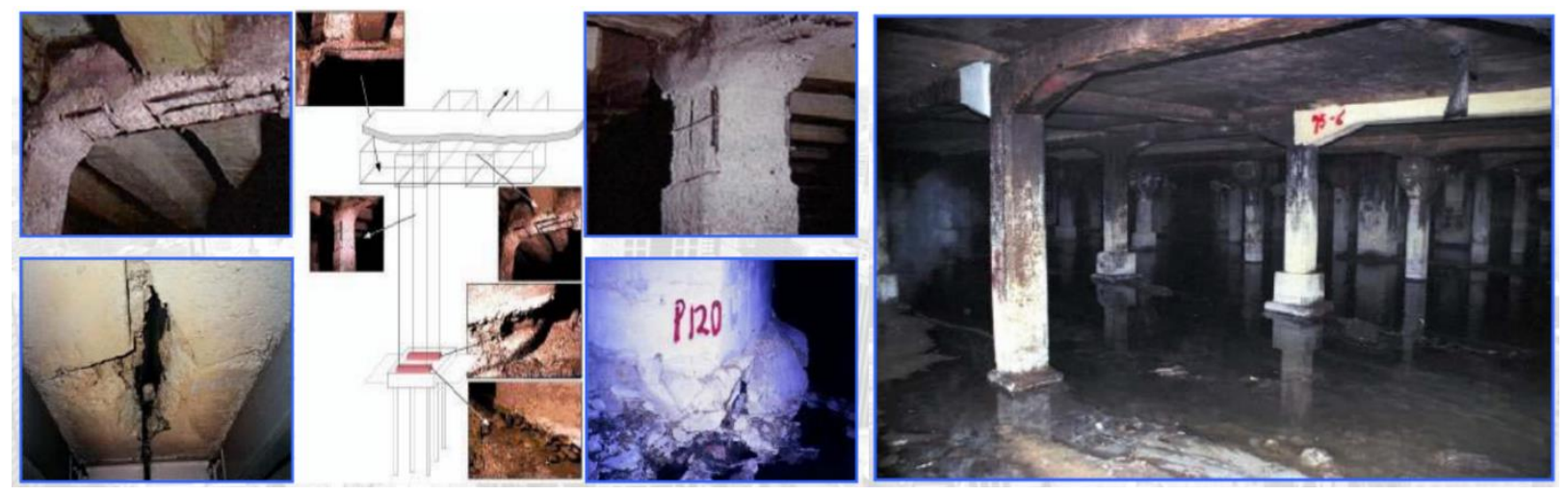

Figure 82: Safety problem in structure portion (source: Cheong Gye Cheon Restoration Project, 2006) 
In 2002, the decision of destruction of covered highway and structure and restoring the river was taken. The landscape design is taken under three circumstances, such as: bringing the history back, urban renewal and revitalization and bringing nature in the middle of the city. This project brings back the economic growth of the city. This place becomes a tourist attraction (Figure 83). Air and water quality are improved, and the temperature of the surrounding area is reduced by an average of $3.6^{\circ} \mathrm{C}$.
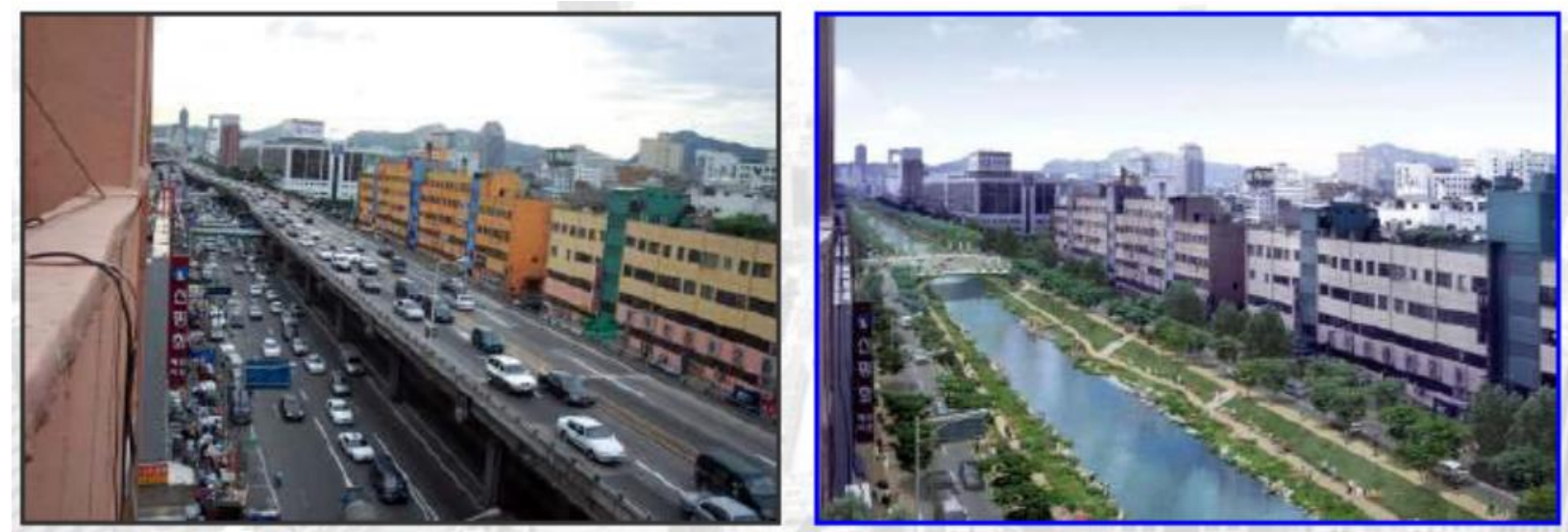

Figure 83: Before the restoration has done and after the restoration has done (source: Cheong Gye Cheon Restoration Project, 2006)

\section{CHAPTER 5: CDNCEPT DESIGN}

\subsection{Concept}

The landscape design portion can be generated in three phases. Such as: Going back to the history for this side, urban renewal, bringing nature in the middle of the city.

Going back to the history of the city: The area was a part of the natural drainage system for the city. There was an urban waterway (khal) before the 1990s. People dumped their everyday waste into that khal, so that it becomes the waste disposal area. At 1991, the culvert was constructed upon the khal to use this waterway as a vehicular road. So, reopening that channel can bring back the history again for this area.

Urban renewal and revitalization: Creating a waterway with transportation and recreational facility, waterfront decks, designing with environmentally friendly material along the water way can revitalize the whole urban area.

Nature in the middle of the city: Converting a road into an urban water way looks natural. Designing the wetland to full fill the purpose of a natural drainage system and to improve the overall urban environmental scenario such as improving the air and water quality, make an ecological conservation area for the city can bring the nature into the city. 


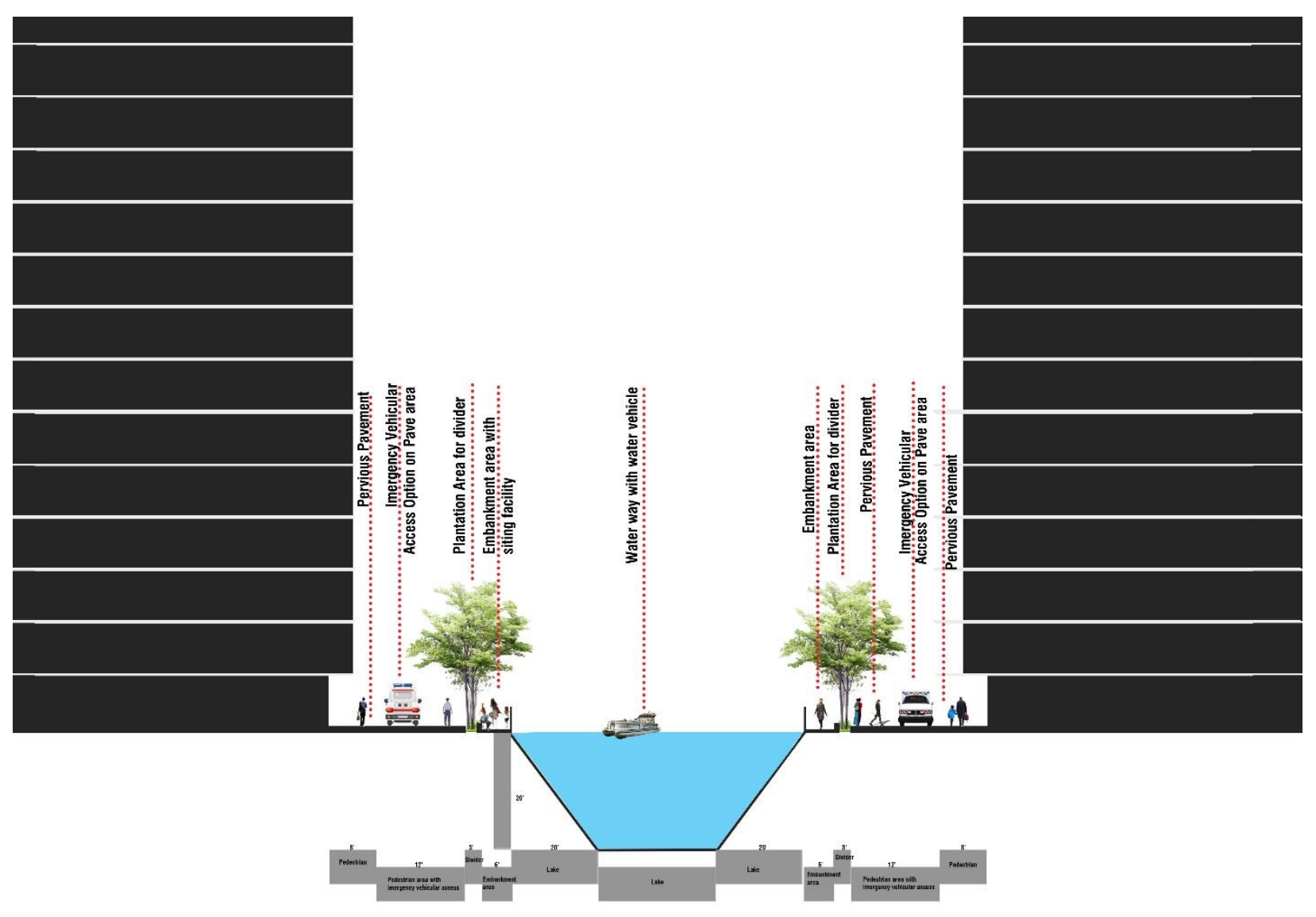

Figure 84: Conceptual sectional diagram

Figure 84 shows the conceptual scenario of the design. In detail design portion, according to the situation, more detailing is provided. It is only the diagram at the basic level.

The whole volume of water is considered here for the area of the lake, other matters such as evaporation, absorption, other ways of collecting rainfall water are not considered here. This is the maximum level for the storage of water. The side area will be designed with pervious material, so that water from the road will not go directly to the lake area. There will be access for emergency purpose as an important hospital is located there. The lake boundary will be designed with pervious material so that water plant can grow to clean the water at the boundary wall and the lake water can recharge the ground level water for the city. 


\section{CHAPTER 6: DESIGN CRITERIA}

\subsection{Size of the waterway}

The size of the lake will depend on the water that we need to collect during rainfall. There should be a catchment area for the study area. The water comes from the surrounding catchment area should be considered to calculate the volume of the lake area. According to the calculation the volume of lake should be (length $=1.6 \mathrm{~km} X$ width $=40$ feet $X$ depth $=20$ feet) 118915 cubic meter. It is the maximum volume. So, if we could consider the other ways to collect and absorb rainwater such as including some pocket area inside the catchment area to collect rainwater, to introduce pervious material for pavement throughout the catchment area, to improve the existing drainage system, to create some open area such as field, rain garden, bioswale area to absorb water, to introduce roof garden for overall area to collect and absorb water then, the lake area can be reduced more than twenty percent. The six seasons of Bangladesh should be considered also to maintain the depth of water level for the waterway. It should be analysis that the water vehicle should run during the dry season and during the rainy season the water will not overflow. It depends on the overall urban planning decision to take the step to define the measurement for the waterway.

\subsection{Facilities beside the waterway}

Several things are considered here to provide any kind of facilities besides the bank of the waterway. After analyzing the typology of building at both side of the area, it is observed that there are some important buildings such as hospitals, banks. So, emergency vehicular access is required. The area is important for the roadside shops and stall. It is not only this area but also the whole county is famous for its roadside stall market, road side farmers market. People are used to do their everyday shopping from these types of the market place. So, a portion is dedicatedly designed for this purpose. There is also the provision of side deck and water boat area deck to make the area more usable for the city dwellers.

The whole area is divided into several zones for planting. The edible fruit trees are selected here to plant. Almost every stall will get one tree to give shade and shelter. Fruit trees are selected here according to the season so that there will be no chance that people come here and cannot enjoy any fruit from the trees. For aesthetic purpose different types of flower plants are chosen here. Obviously, the flower plants area chosen here for all six seasons, so that flower can bloom throughout the whole year.

For erosion purpose, different types of ground covers are planted here. At the bank area, aqua plants are provided. Water plants those have the quality of absorbing waste material from the water are selected to plant here.

The whole area is designed as a pedestrian-friendly area with providing emergency vehicular access. After analysis the road connectivity for this area, it is decided that if an alternative road can be provided behind the buildings here, it would be more purposeful. There are some provisions to provide an alternative road network behind the building. This decision should come from the 
urban planning department for the city scale to provide service for the important building of this road.

The area can be an education center for the children to learn about the plants of Bangladesh and the environment, as there is very little opportunity like this at present city condition. In terms of environment, the design proposals are useful to improve the air and water quality for the city area.

\section{CHAPTER 7: DETAILED DESIGN}

\subsection{Proposed Design}

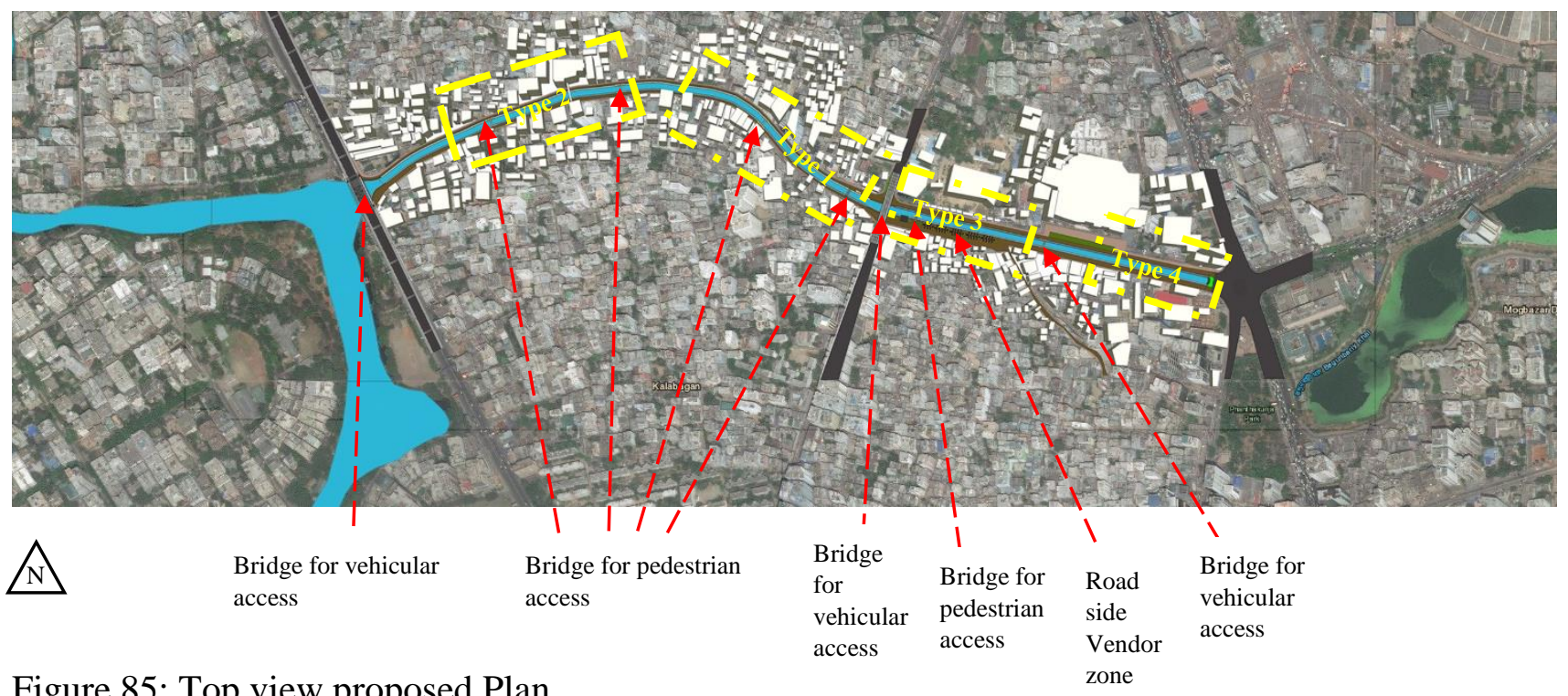

Figure 85: Top view proposed Plan

Figure 85 is showing the proposed condition for the area. The proposed waterway is located almost at the center of the area. The length of the proposed waterway is $1.5 \mathrm{~km}$. Different types of conditions are provided here. Where other roads lost their connection, bridges are provided for vehicular access and pedestrian access. There are six foot over bridges, four of them are designed for universally accessible. A designed zone is dedicated to street vendor purpose. Roadside stalls are designed here to collect rainwater for maintenance purpose for this area.

It is shown here that, there are four types of situation here. The whole area is having the mixing condition of all types. That means, only the showing portion does not have the one type, that is mentioned here. Others portion also have elements of other types. This category only follows the previously existing condition.

For type 1 (Figure 86, 87, 88, 89, and 100), it is the typical scenario for the overall area. The waterway is almost at the center of the vehicular road. There are lakeside road and bioswale portion, which make the division between the main pedestrian road and waterway. The embankment edge with the railing portion and green belt beside the sidewalk are provided for 
safety purpose (Figure 100 and 103). It is shown here, that, there is a slope condition at the embankment portion. It is up to an engineering solution to define the design detail for the embankment. Having slope at embankment portion rather than having a vertical wall, gives a more natural look. Aqua plants which are useful to clean lake water are proposed to plant at the embankment wall.

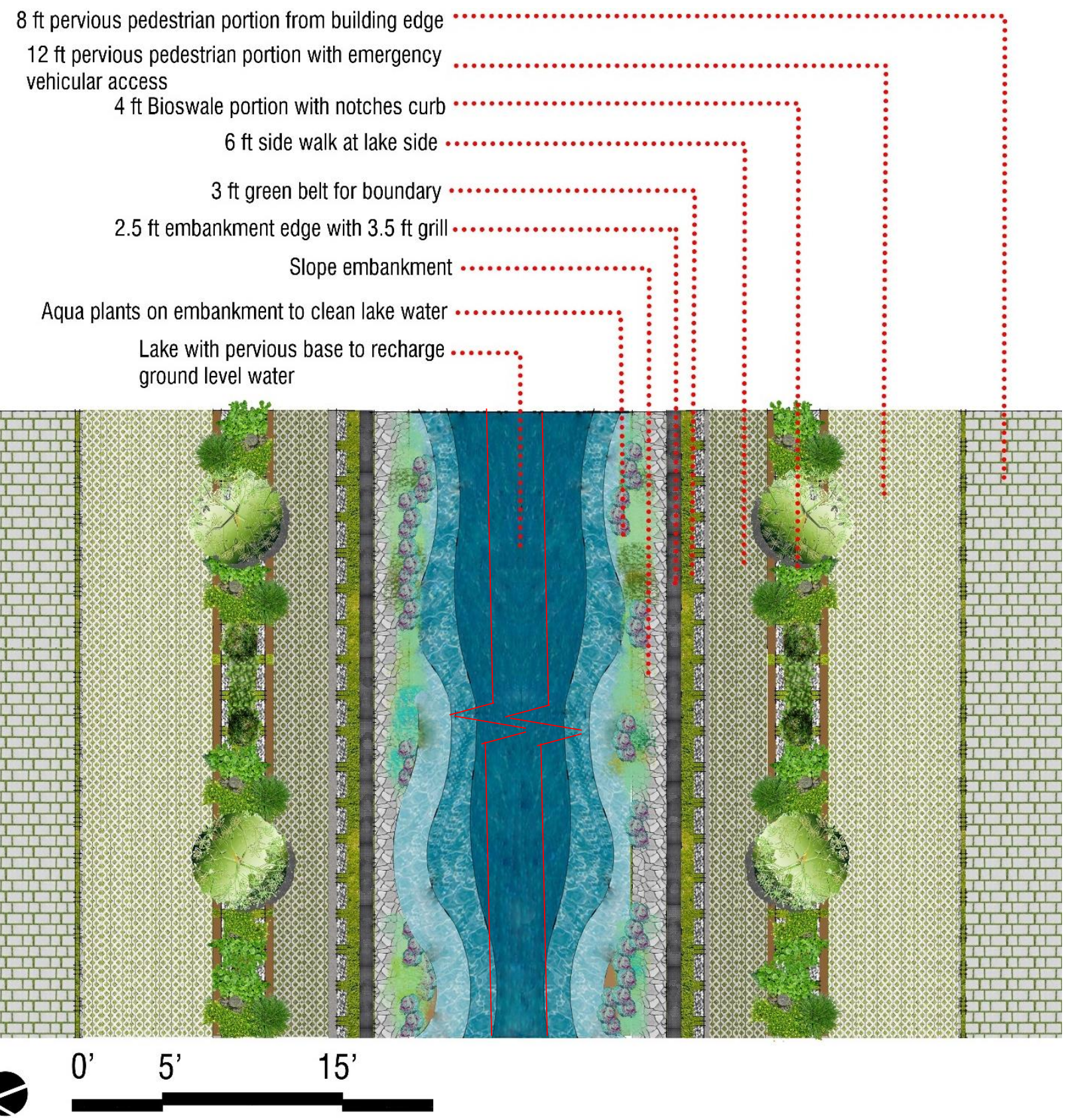

Figure 86: Type 1, Plan view of typical condition 


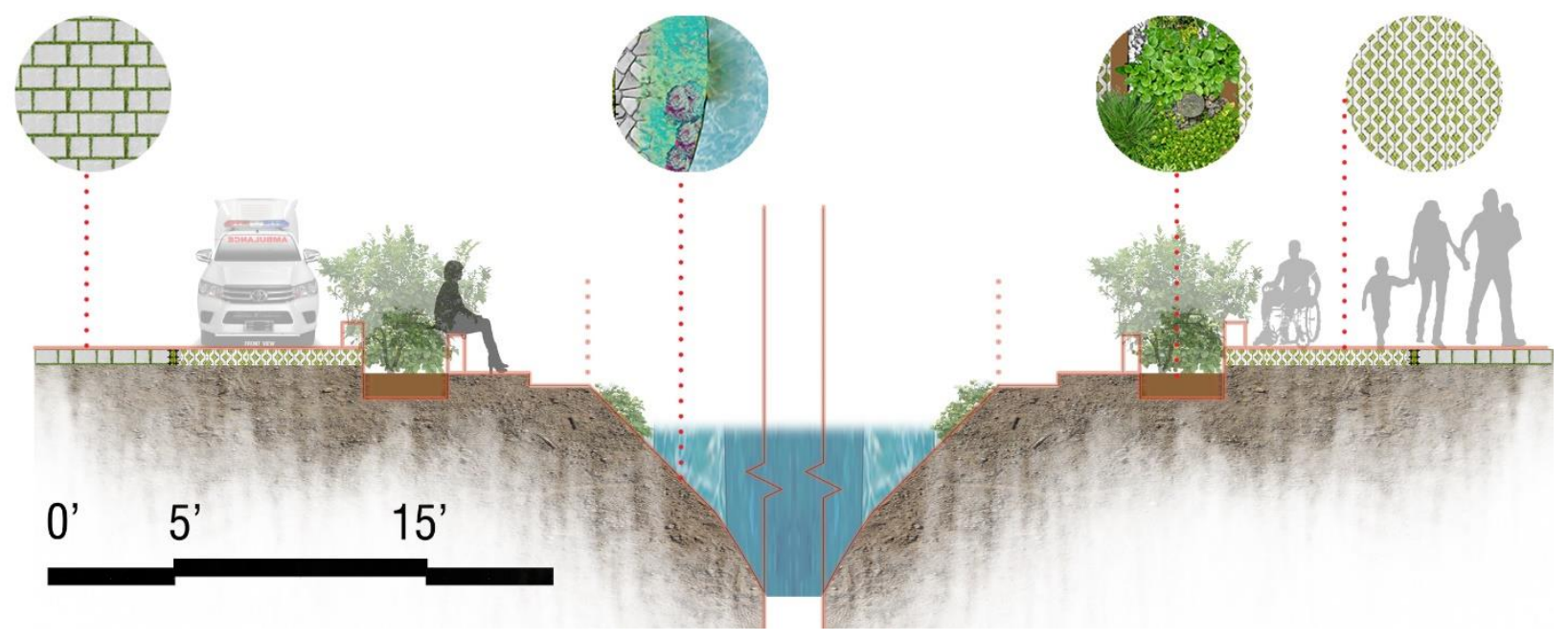

Figure 87: Sectional view of typical condition

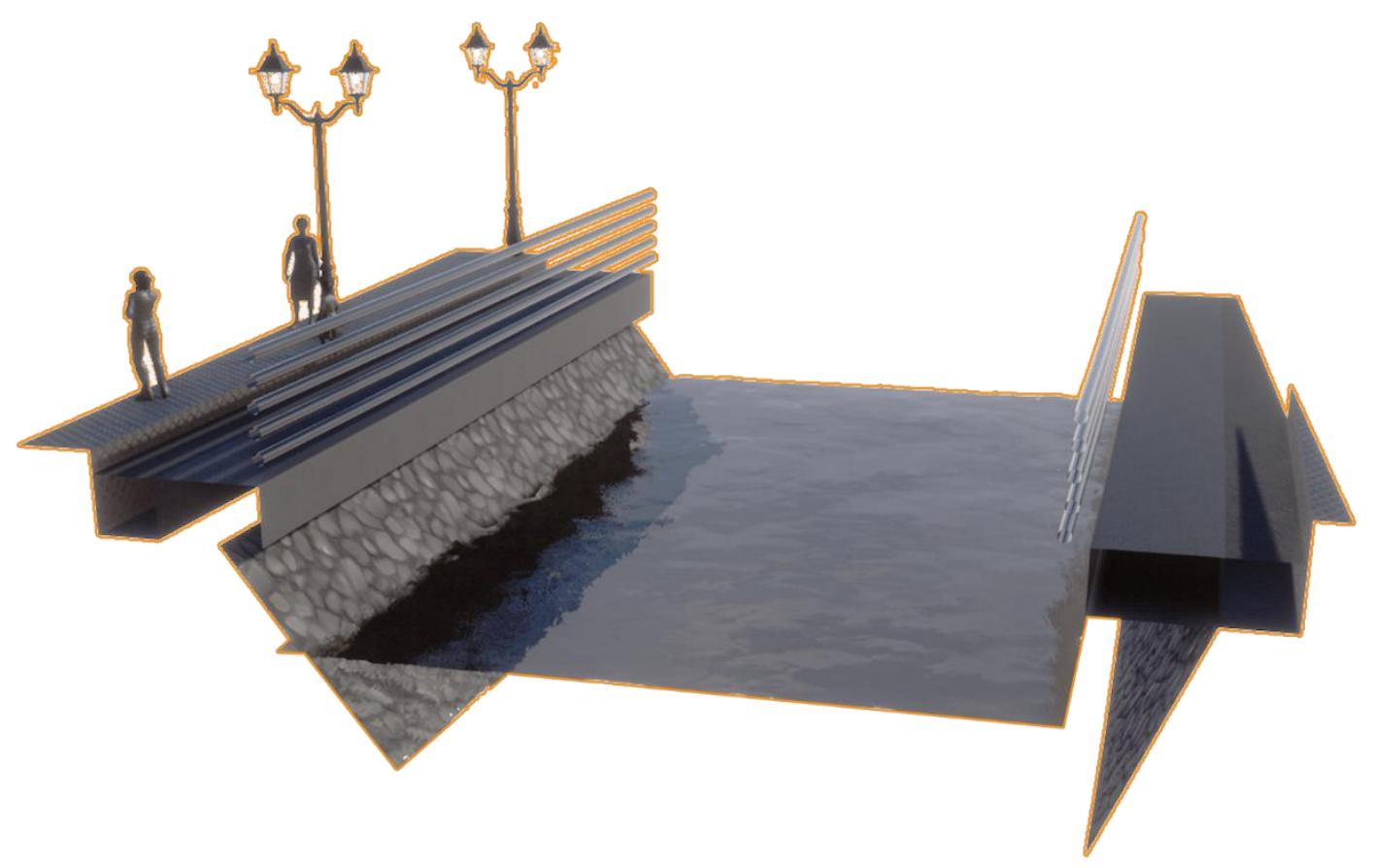

Figure 88: Typical condition of waterway side 


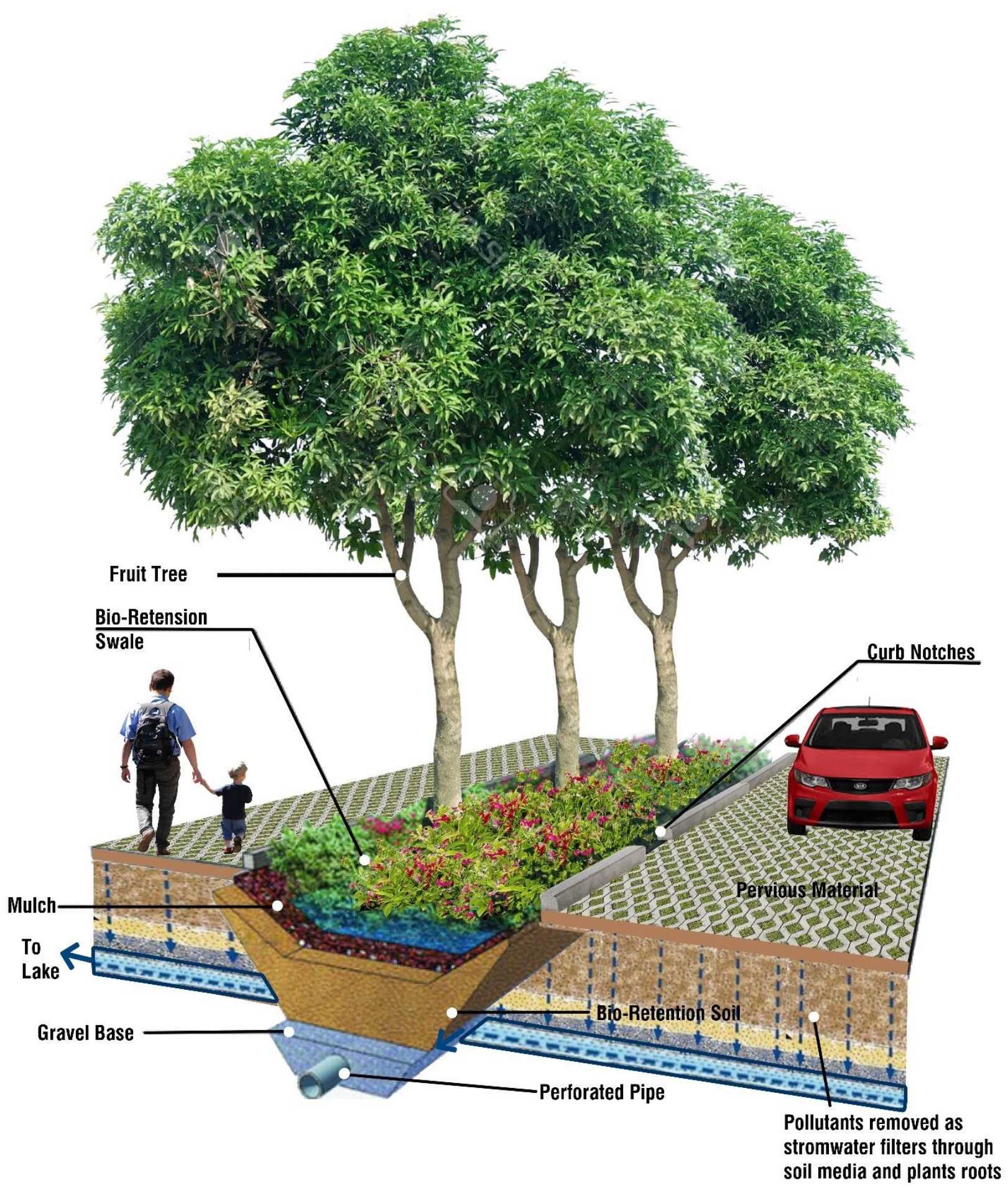

Figure 89: Bio-swale portion

For type 2 (90, 91, 92 and 93), the bridge is placed for pedestrian and vehicular access. There are total six foot over bridges here. Four of them are for universal pedestrian access. The green belt and edge of embankment portion of the typical condition is used as the entry part ramp for the foot 
over bridge (Figure 101, 102 and 104). The bridges are placed specially near where other local roads lost their connection for placing the waterway here. Bridges will add the pedestrian connection from one side of the waterway to other side. So, pedestrian connectivity will increase throughout the area. There are two bridges for vehicular access. One is at the middle of the waterway length, where a secondary road crosses the Panthapath road and another is at the end of Panthapath road, where it connects with Mirpur road.

$8 \mathrm{ft}$ pervious pedestrian portion from building edge $12 \mathrm{ft}$ permeable pedestrian portion with emergency vehicular access

$4 \mathrm{ft}$ Bioswale portion with notches curb

$6 \mathrm{ft}$ side walk at lake side

$3 \mathrm{ft}$ green belt for boundary

$2.5 \mathrm{ft}$ embankment edge with $3.5 \mathrm{ft}$ grill

Slope embankment

Aqua plants on embankment to clean lake water

Lake with pervious base to recharge ground level water

Bridge for pedestrian purpose
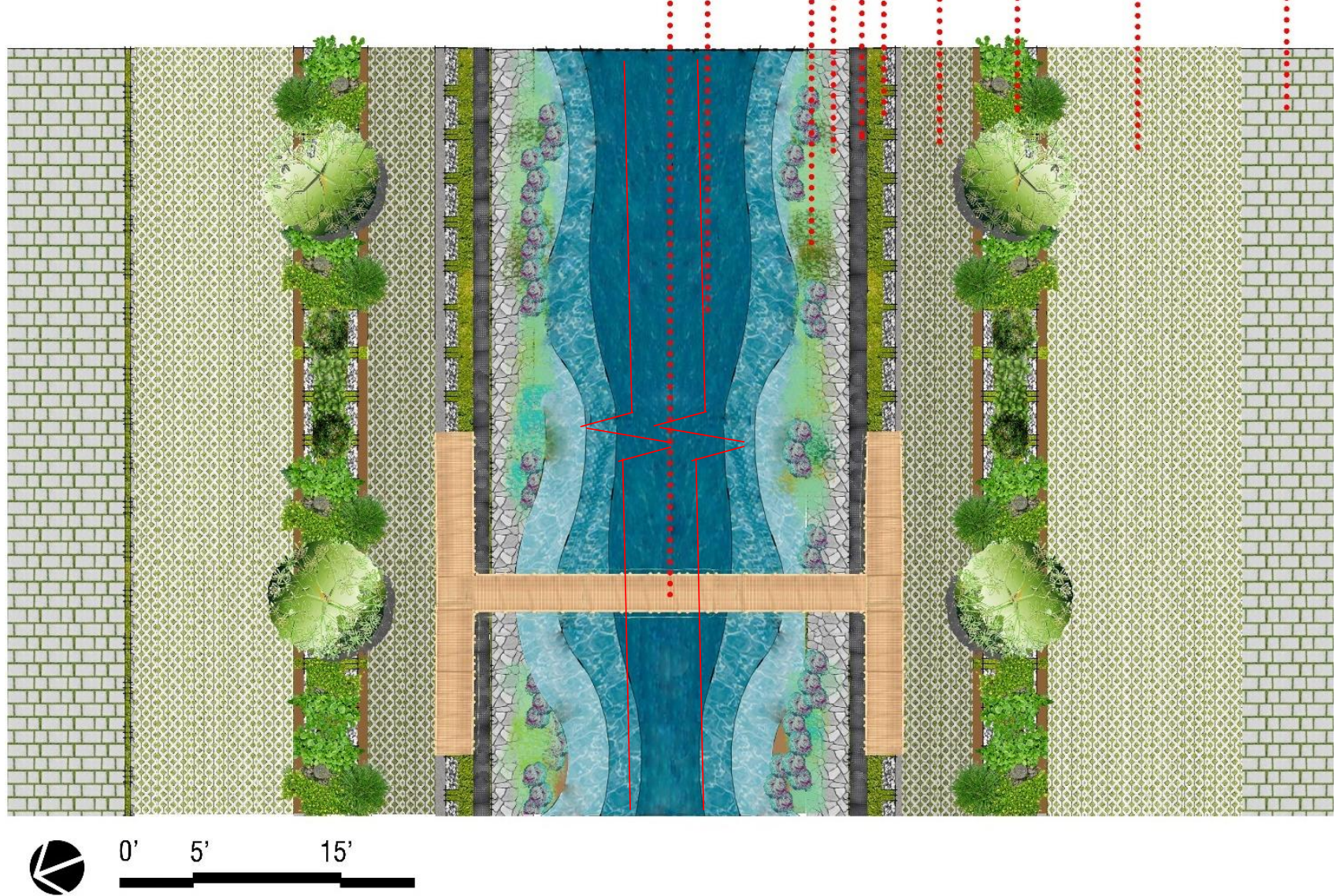

Figure 90: Type 2, Plan view of Pedestrian bridge condition 


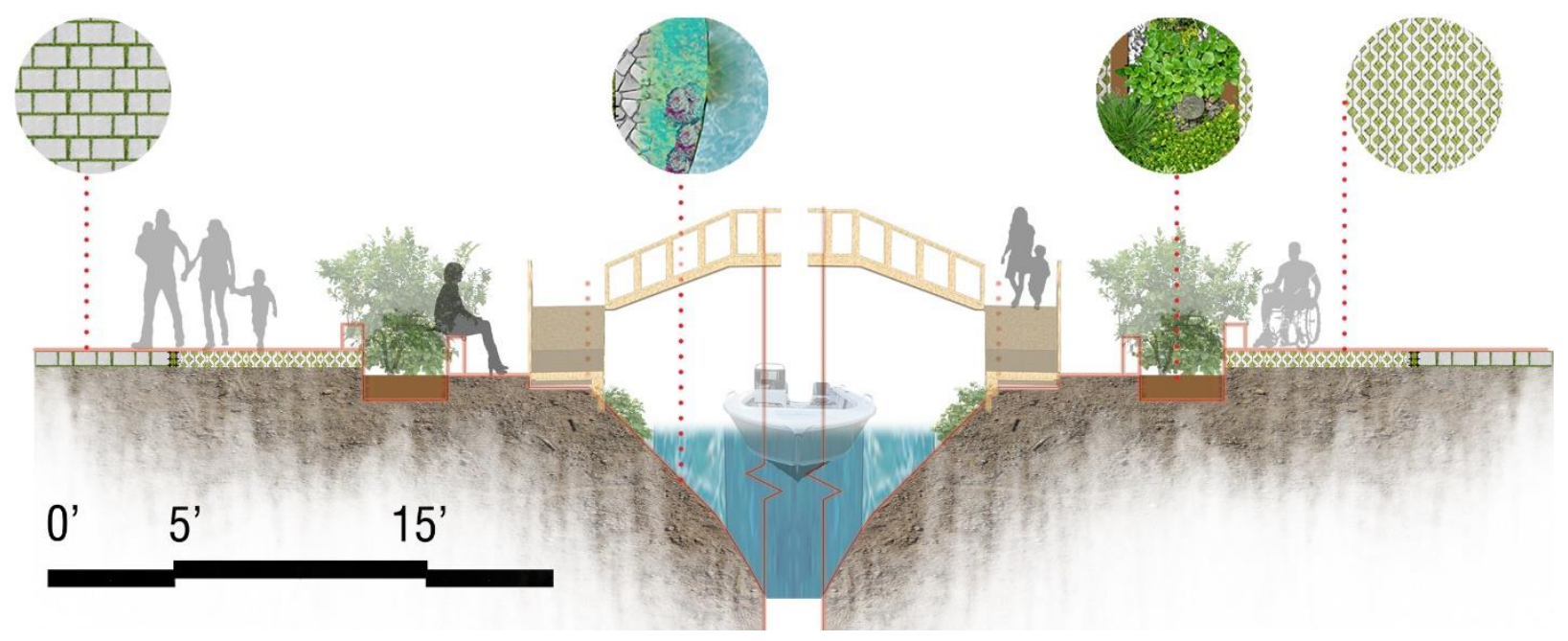

Figure 91: Sectional View of Type 2

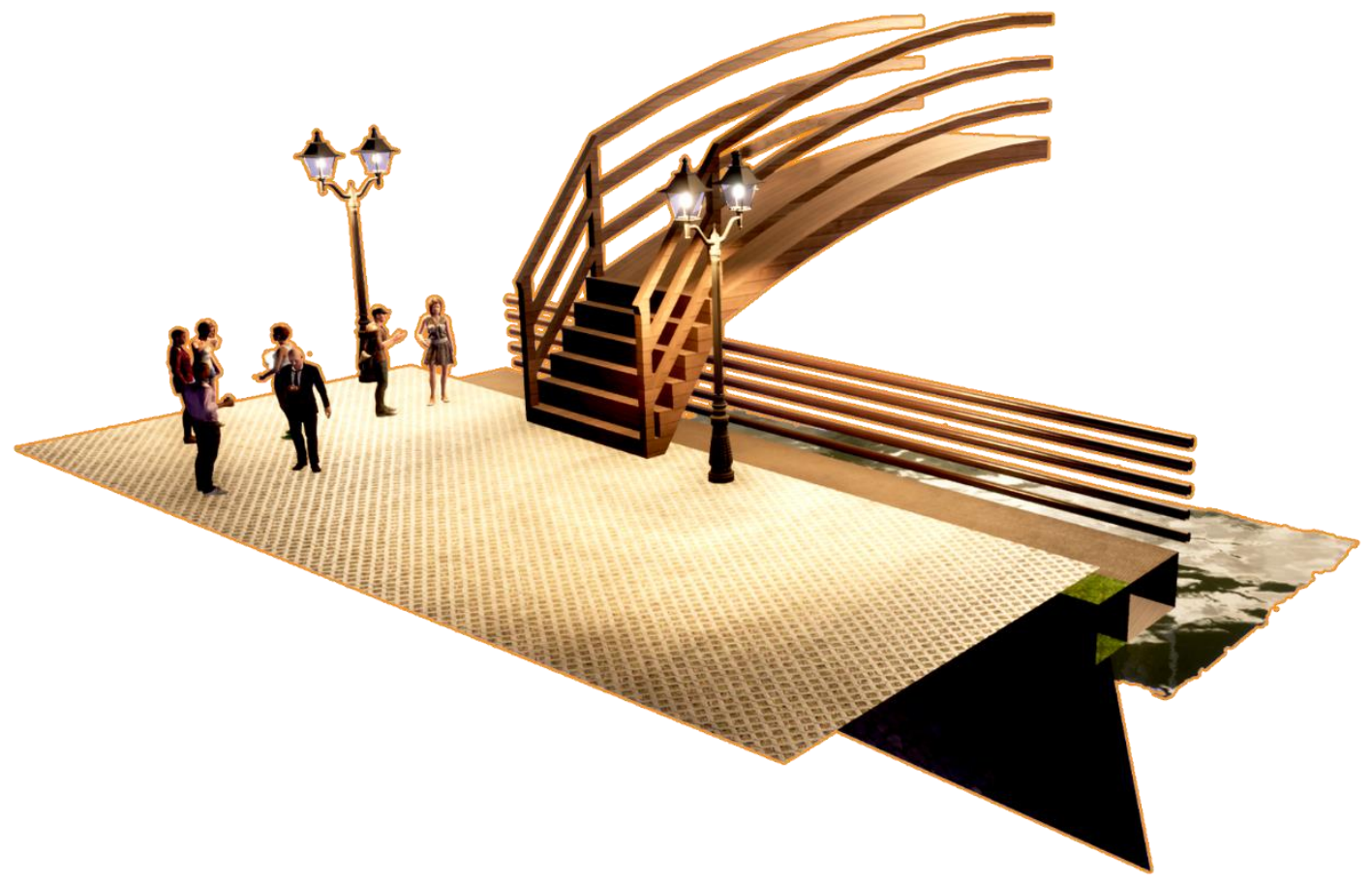

Figure 92: Bridge for Pedestrian Access 


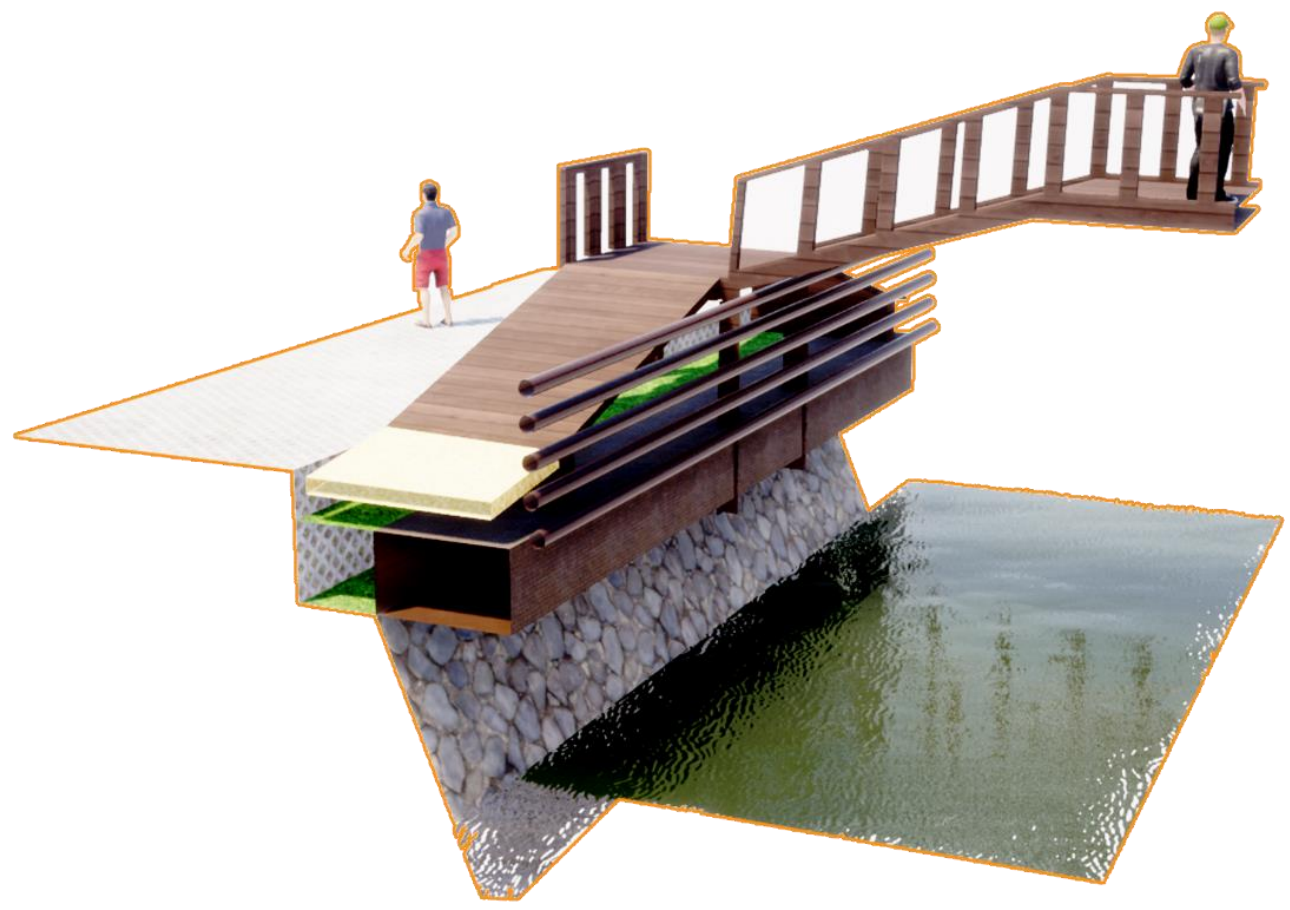

Figure 93: Bridge for Universal Pedestrian Access

For type 3 (Figure 94, 95 and 96), spaces are provided for street vendor purpose in a designed way. In Bangladesh, city's streets are famous for having different types of street stall. People like to buy their daily commodities from these types of street shops during coming back from their working places. Some of those are for street food, fruits, tea, snacks, daily grocery or daily accessories like clothes and other usable materials. The products of these shops are less expensive. So, people feel attracted to come to street stalls for shopping.

The big trees are placed here to provide shade for shoppers and visitors. Only the shading and structural elements are providing here, so that the place can be used for different types of stalls (Figure 98, 99). The roof of the shops is designed to collect rainwater for the maintenance purpose of shops and the surrounding area.

Every stall will cover from $8 \mathrm{ft}$ to $10 \mathrm{ft}$ space. Every stall will have cabinet and deck to present the commodities. The surrounding of the shop will provide waste management disposal. The structure of the stall will be prefabricated, so that it will be easier to install the structure at the project site. To collect rainwater, every stall will have storage for water.

For sitting near any stall, the sculpture like seating area will be provided. The street seating area will be designed in such a way so that people will use that for shopping purpose. For maintenance purpose, a system should be made throughout the area. The design has several scopes to make any kind of plan to implement due to this purpose. 


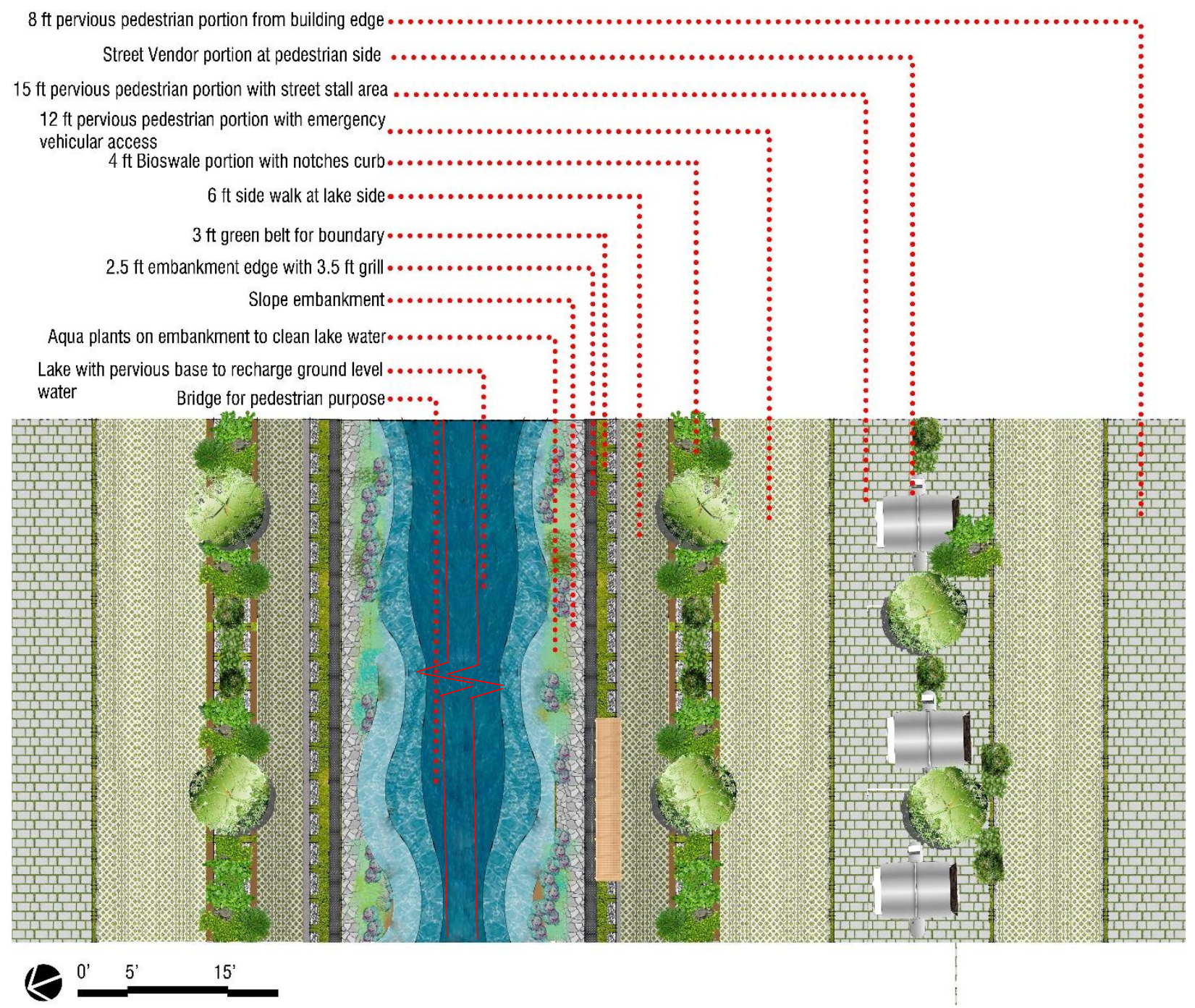

Figure 94: Type 3, Plan view of Pedestrian side stall portion

For type 4 (Figure 97), it is the end part of the waterway portion where Panthapath road meets at the circle of SAARC Fountain. The waterway is closed here, so a buffer zone is provided here with safety railing and green zone. As the proposed permeable pedestrian and emergency access portion are $1 \mathrm{ft}$ higher from existing road level, to make it as the same level as building entry portion, so a ramp portion is provided here at both end portion of this waterway to smooth the accessibility. The western end has the bridge for vehicular access.

In the future, maybe the east end will connect with the Hatirjeel-Begunbari waterway. Then an over bridge is needed to provide at this connecting point. A large waterway network will begin to evolve at this point for the city network. It can be a starting for the future blue network in terms of waterway. 


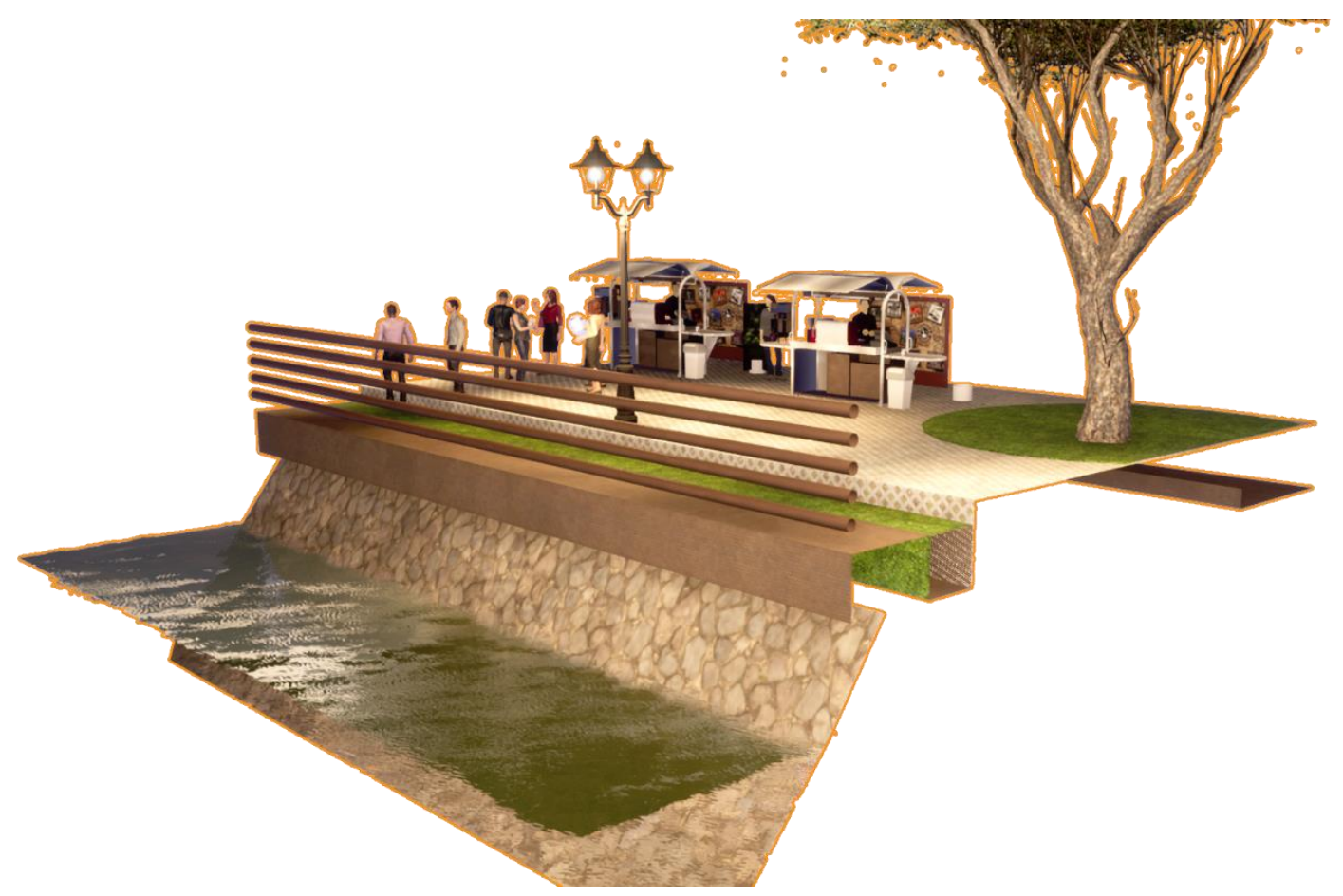

Figure 95: Vendor portion at waterway side

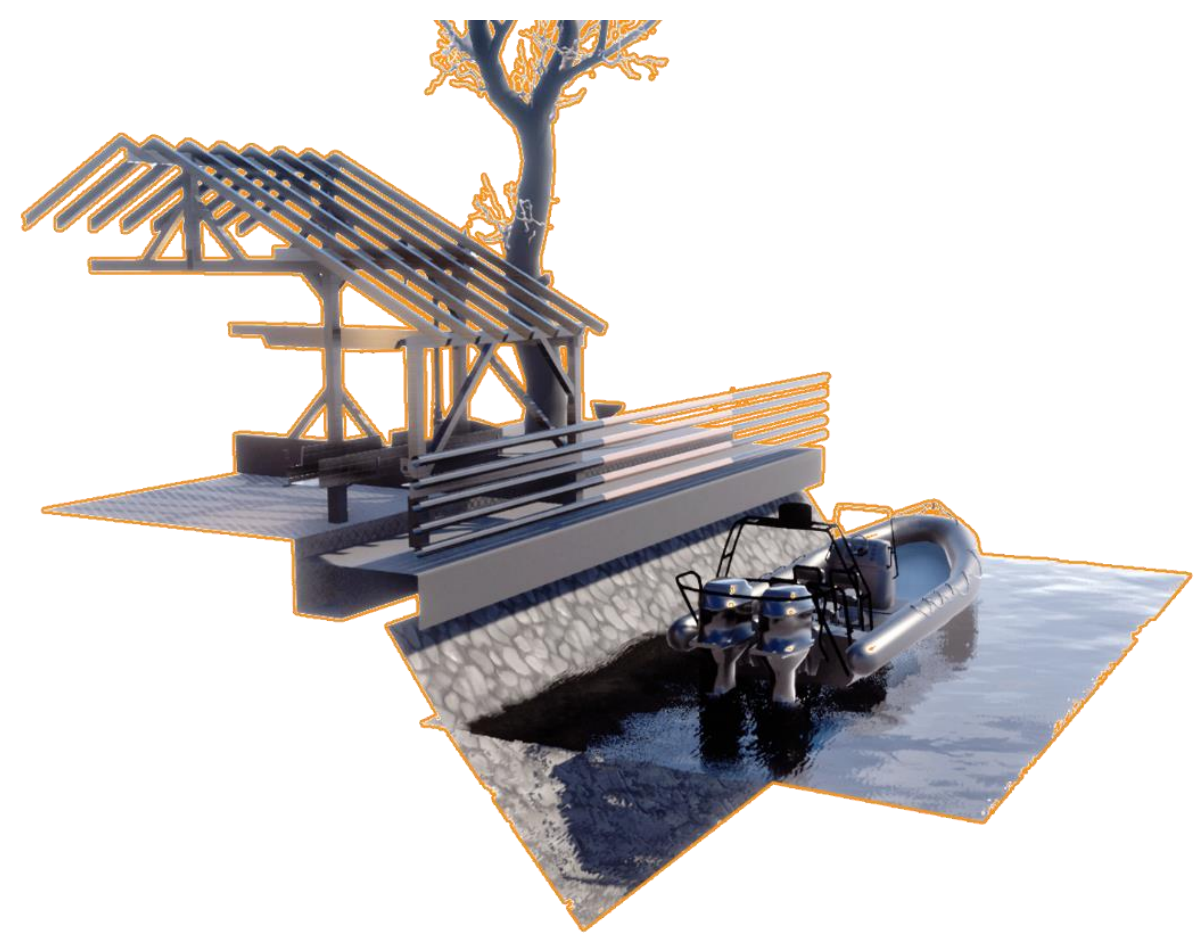

Figure 96: Place for riding water vehicle 


\subsection{Perspective}

Several perspectives are presented here to show the images of the designed idea. For every perspective, captions are written to describe the scenario.

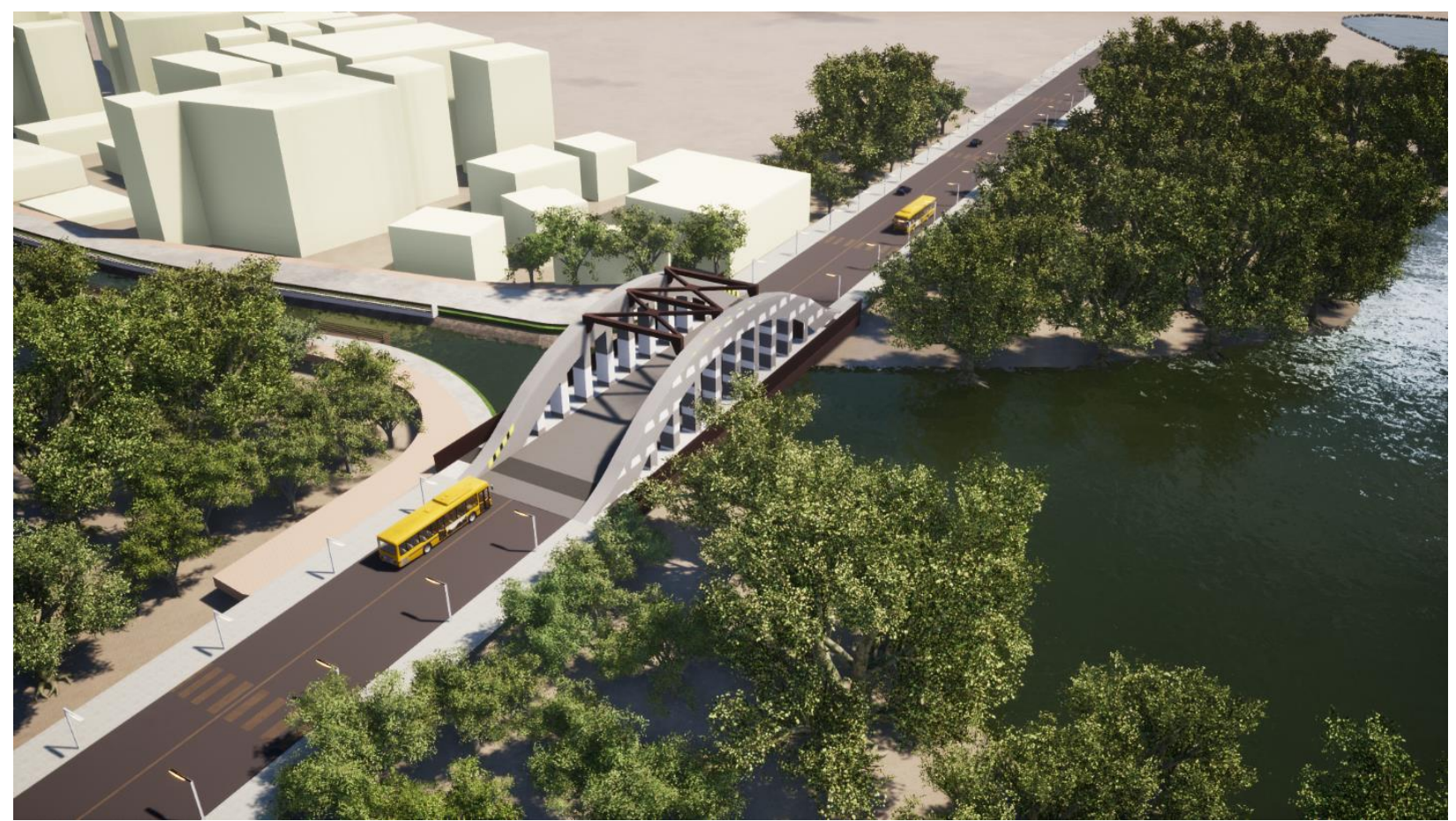

Figure 97: Connection point between Panthapath and Mirpur road area

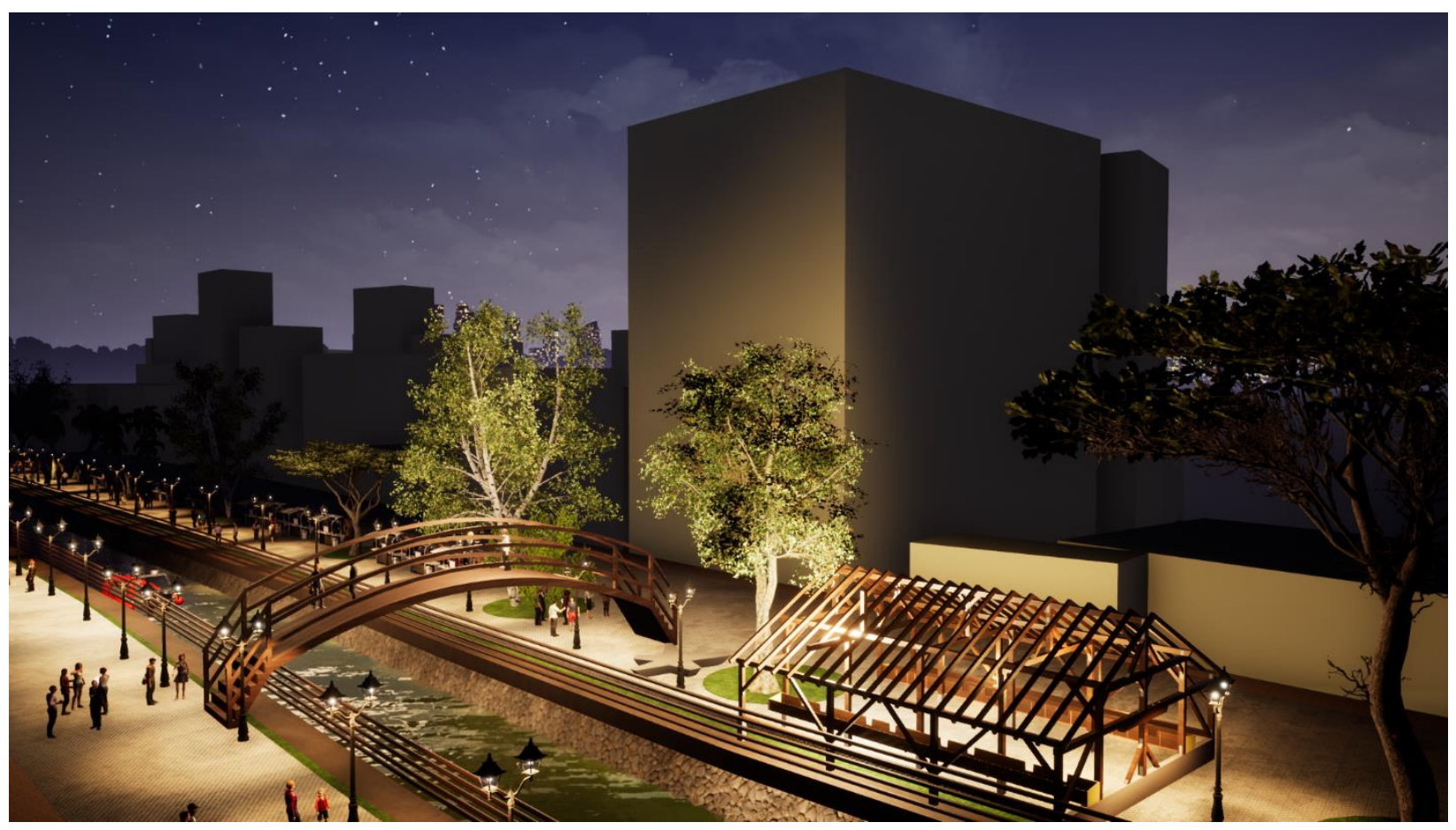

Figure 98: Night view at waterway side 


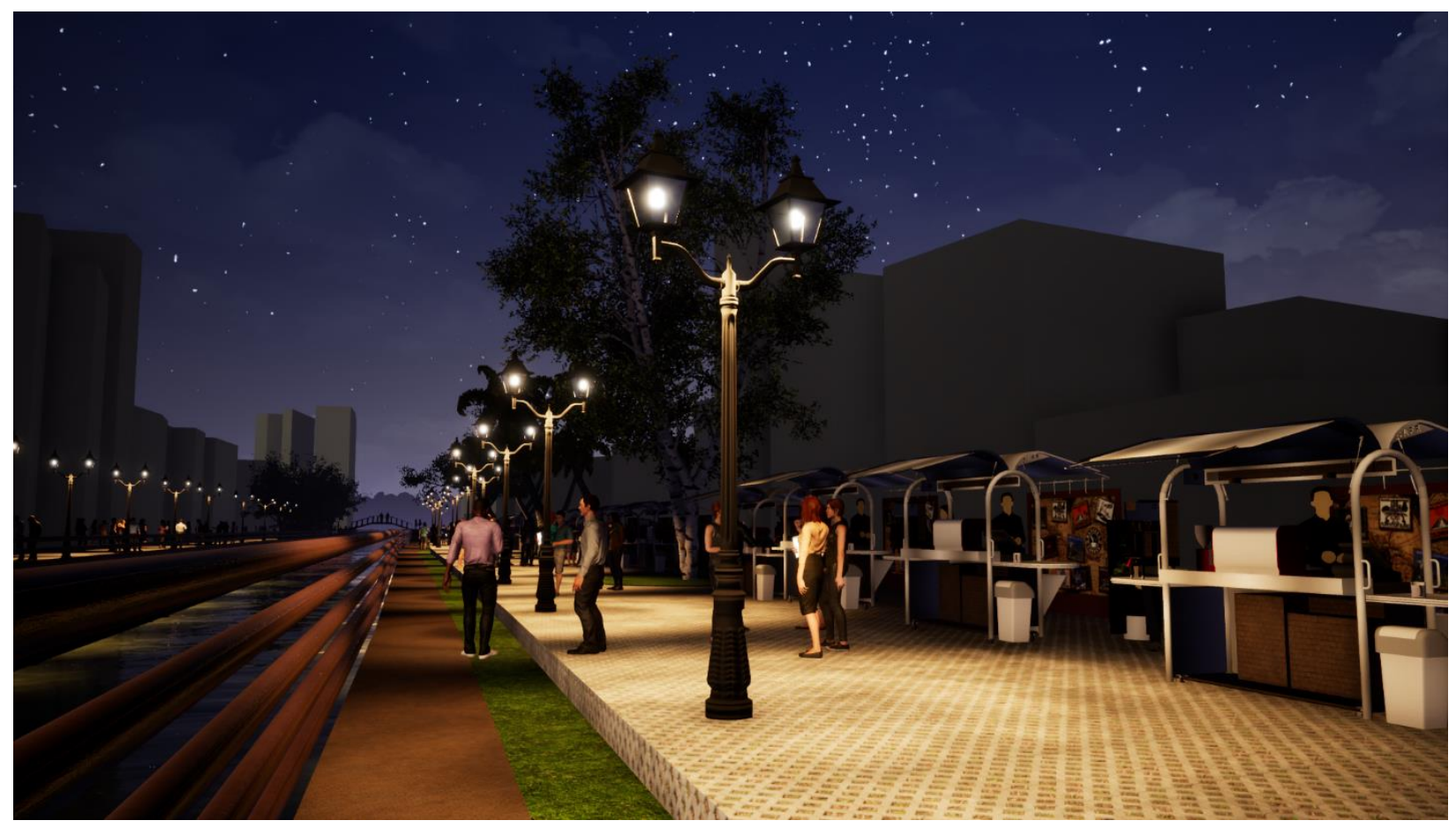

Figure 99: Lake side stall view

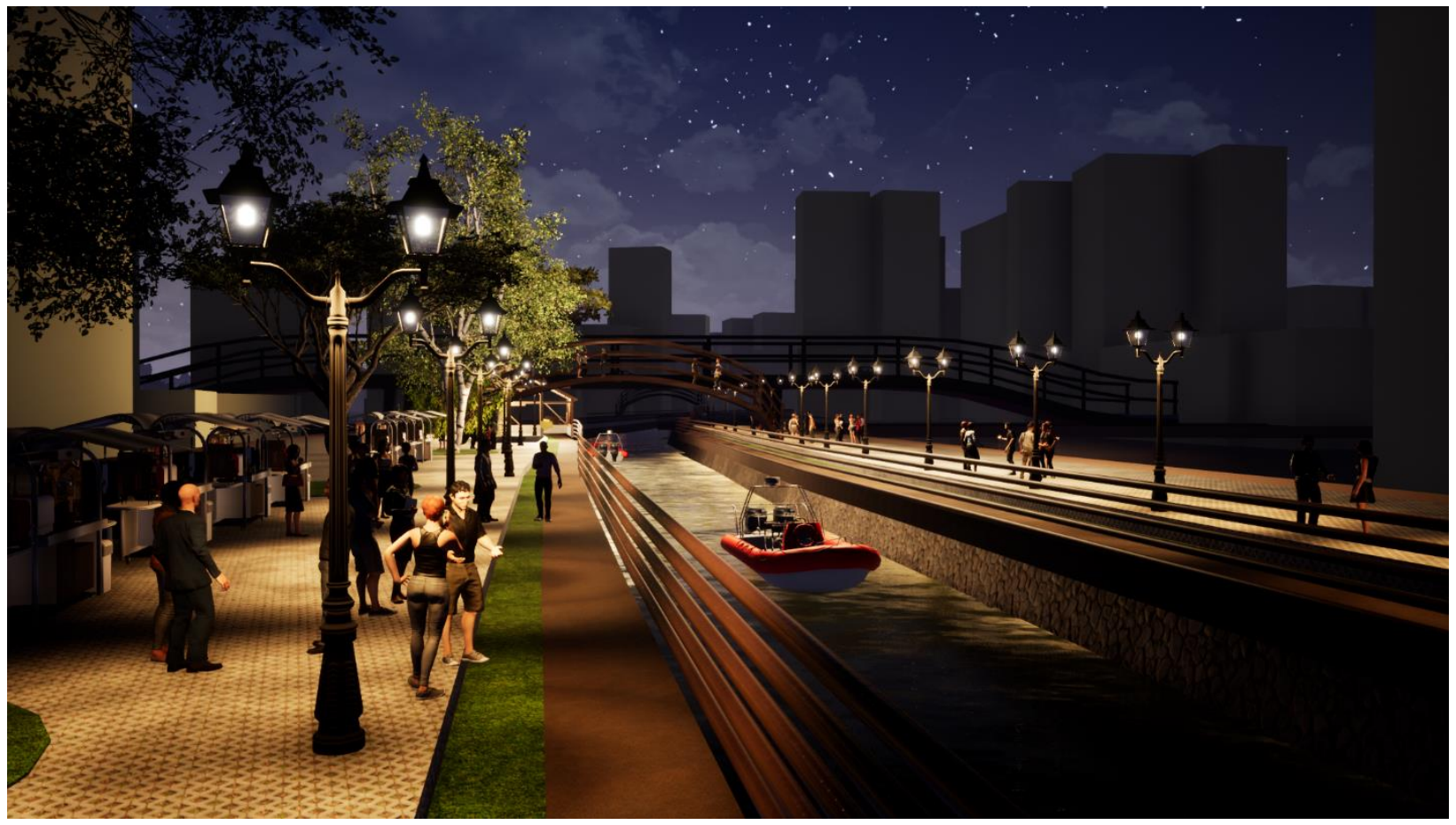

Figure 100: Using water vehicle 


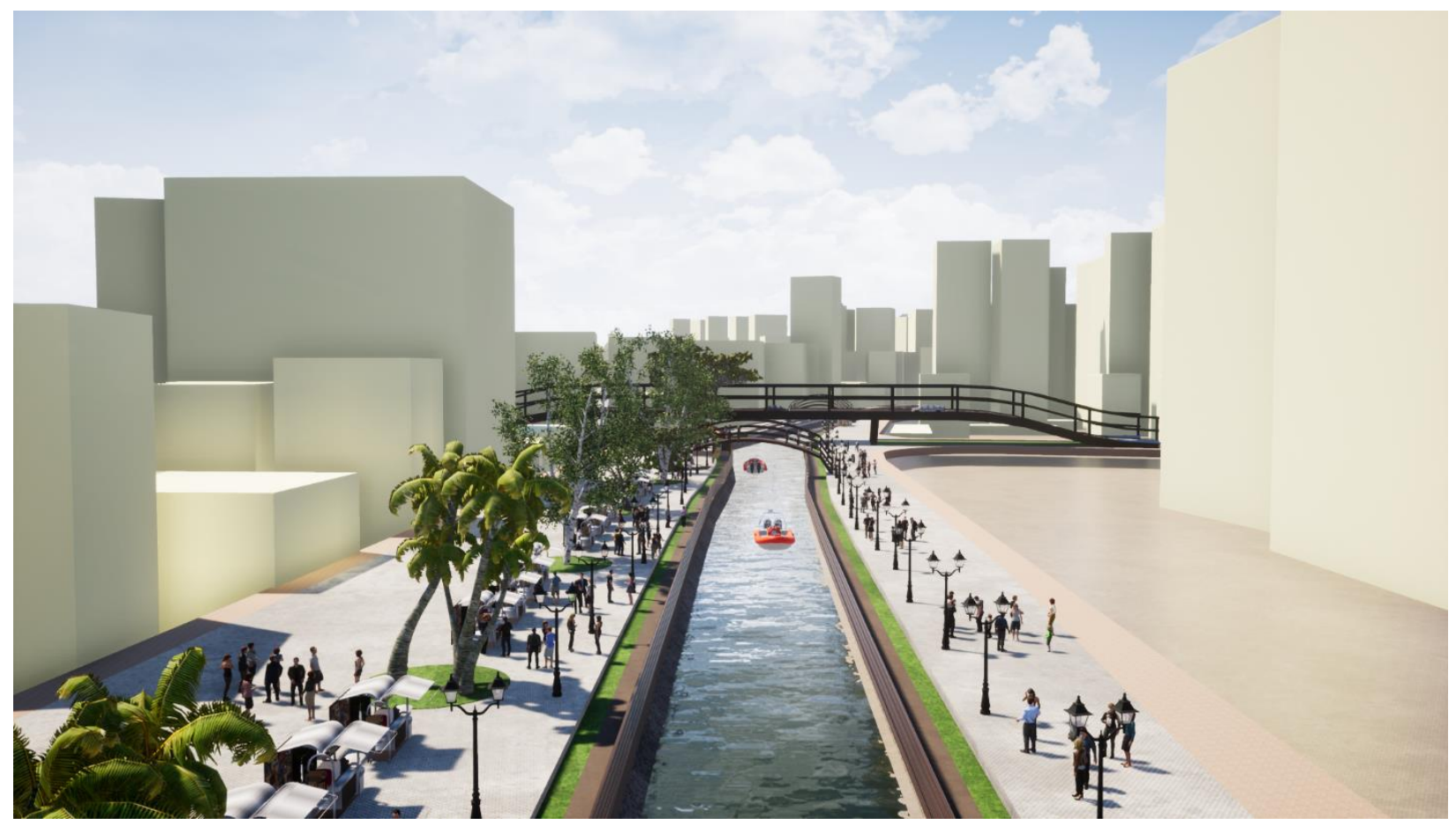

Figure 101: Bridge for vehicular access at the connection point of Panthapath and Green road

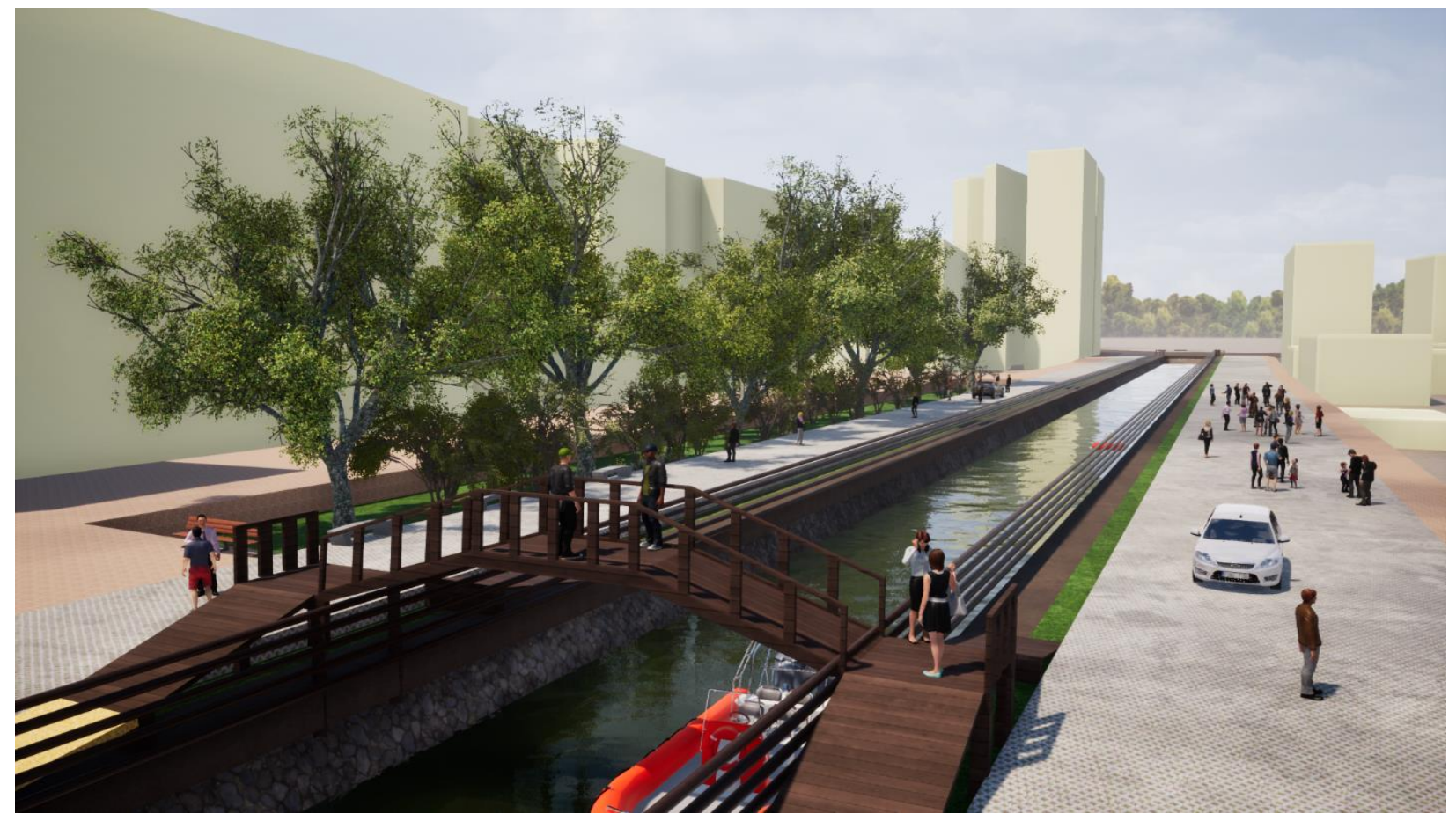

Figure 102: Bridge for universal pedestrian access 


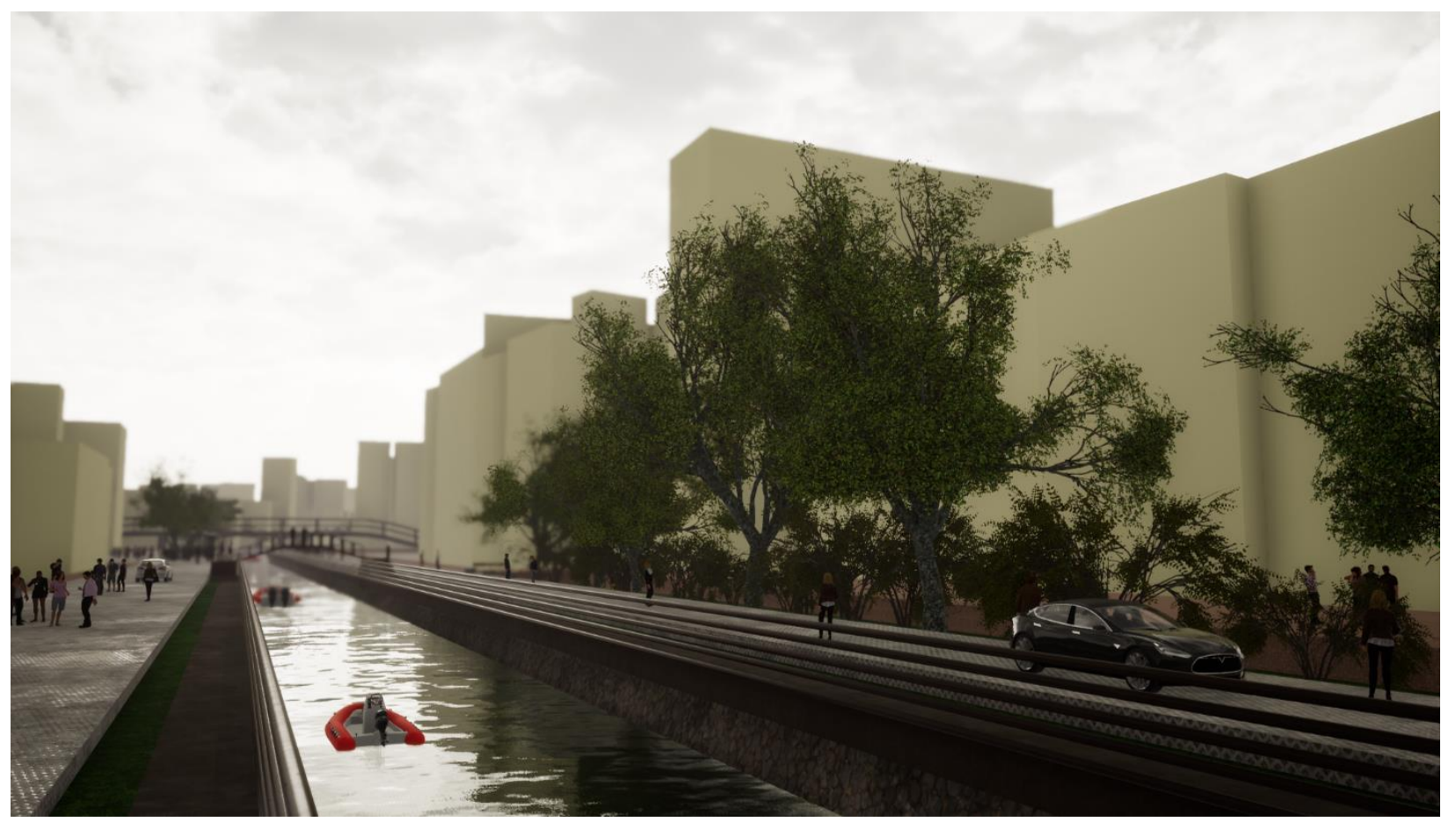

Figure 103: Vehicle can enter here for emergency purpose

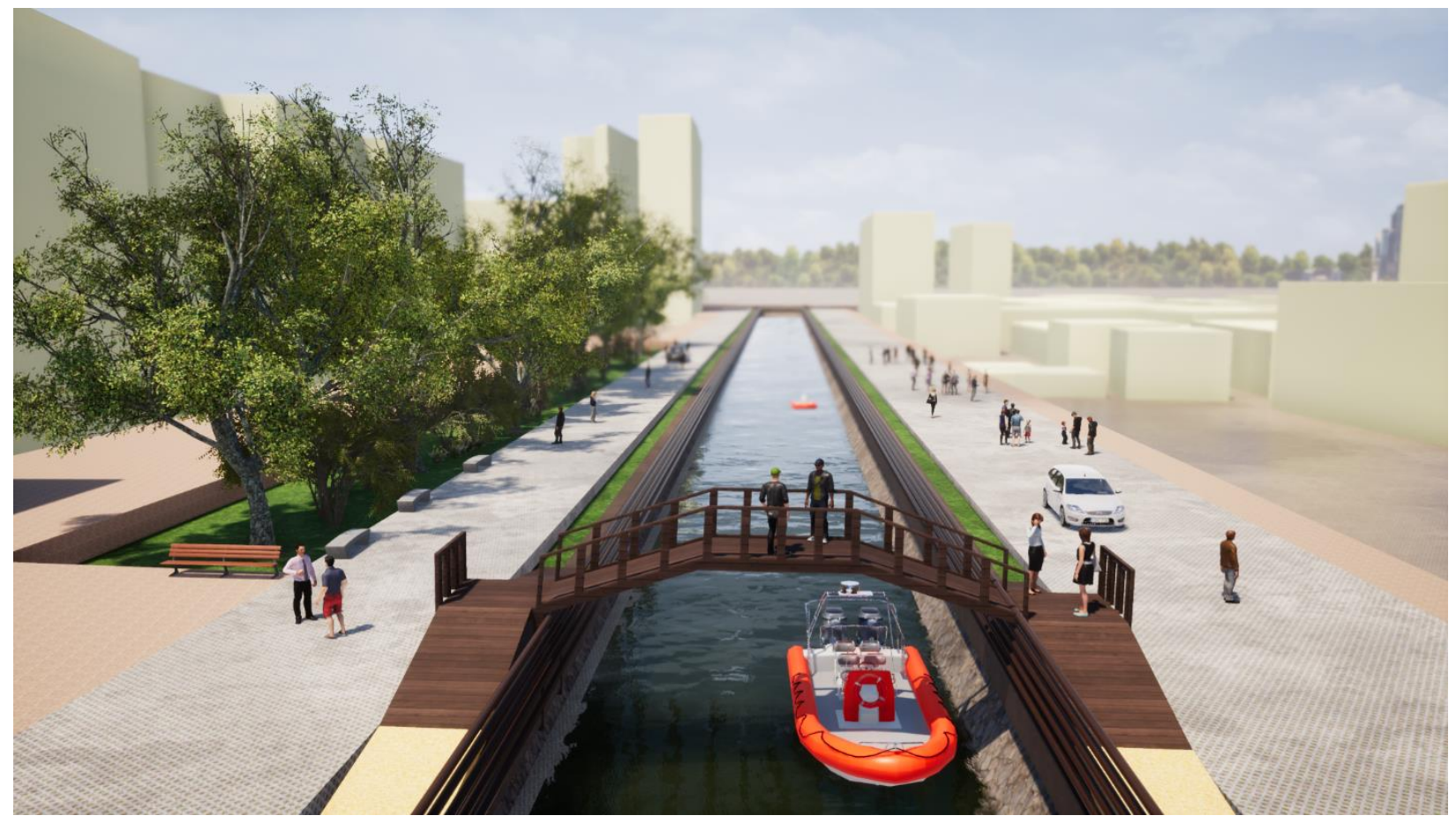

Figure 104: Lake side view in-front of Bashundhara City Shopping Complex 


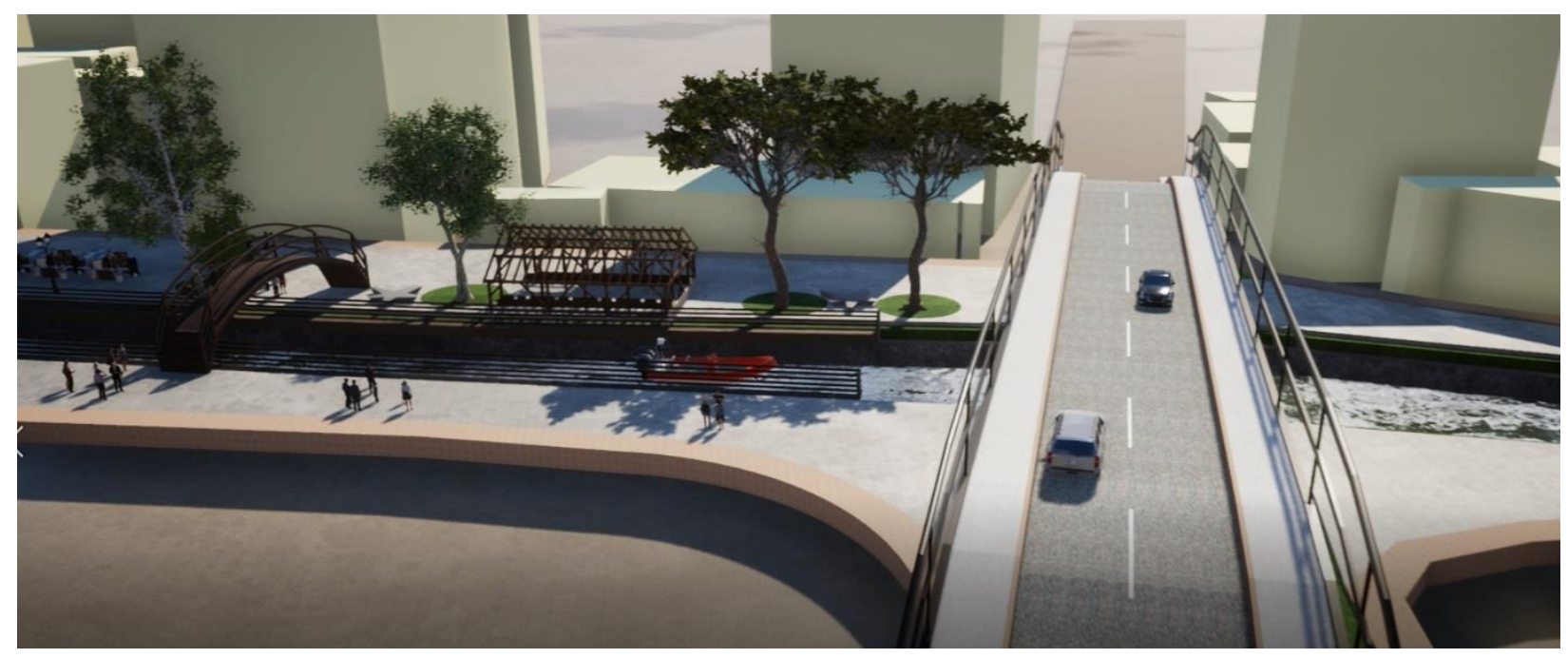

Figure 105: Lake side view from vehicular bridge

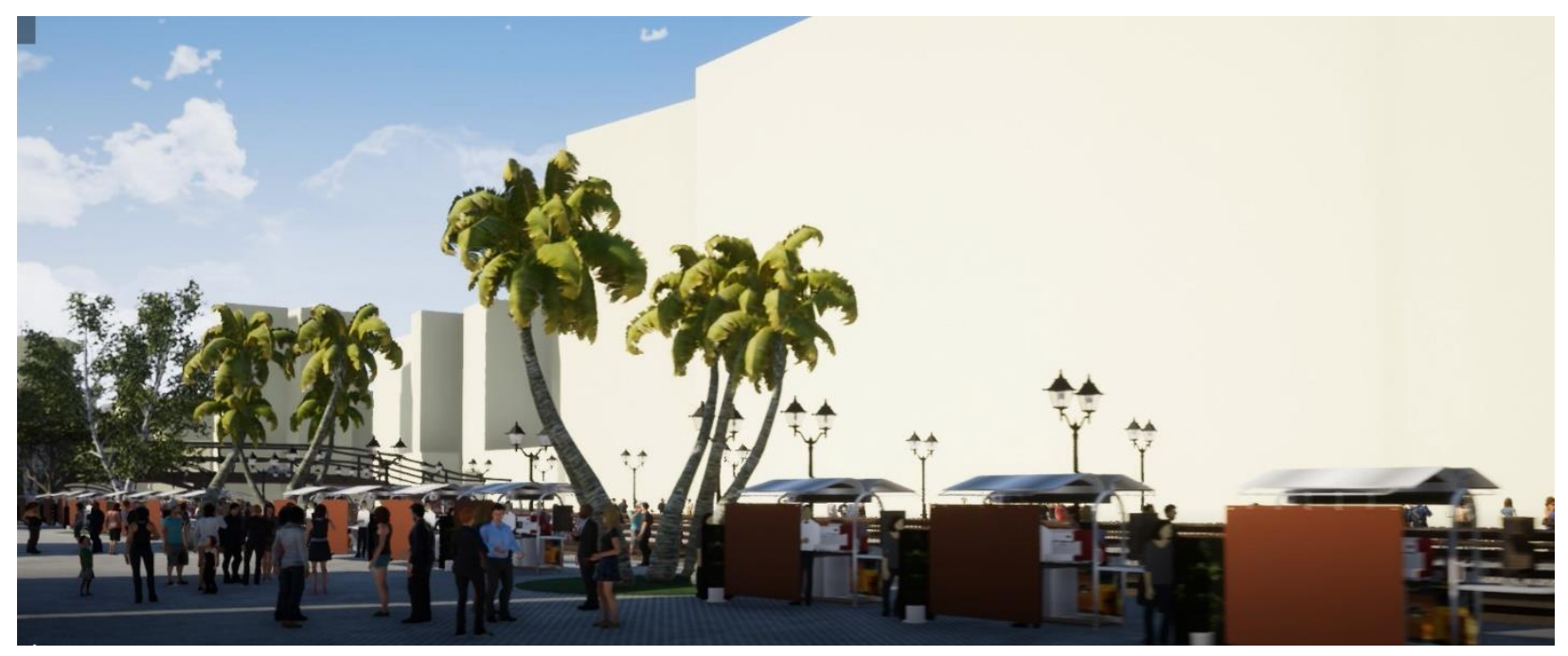

Figure 106: Vendor shop from Pedestrian portion

Perspectives are made here to provide an overall understanding of the design proposal. The design proposal is very simple, and it flows the form follows function rules. The main objective was to make a possible solution for the waterlogging problem. Making the transportation option as a secondary object of this project makes the design simpler. This area is very important for people of every working level, so people need to pass this area in the shortest time period during working hour. This design only provides the design solution for the almost straight waterway which is only following the present road alignment. Any kind of amusement type waterway only take some valuable times from the passerby. 
Other amenities provided beside the proposed waterway just the replication of present road condition. Some ecological design proposals are given here to make the whole area eco-friendlier and make the overall environment better than before.

This natural looking environment will not work for this area only but will keep an impact on the whole city.

\subsection{Plant Selection}

Some principles are proposed here to select plats for this area. To improve the air and water quality, to sustain the local environment and to create an ecologically friendly environment planting design is important.

\section{Plant selection principles:}

Choose local plants: Consider local climate, sun exposure, soil type to choose plants.

Choose fruit plants: To provide nourishment for the visitors, different types of seasonal fruit trees are chosen here. It will not only helpful for the children to know about local fruits but also people will enjoy their passing time here. The whole area can dedicatedly improve local fruit market and can serve as a local farmers market.

Choose edible plants: Selecting different types of edible plants can add extra value to the local farmers market. The whole area can work as an urban agriculture farm.

Conserve water: Some plants will be planted here to absorb water. Especially at and near the embankment area.

Nurture the soil: Promote beneficial soil organisms, adjust the soil with compost before planting, recharge ground level water.

Conserve energy: Plants will provide shade to vendors, paved areas and visitors.

Protect water and air quality: Aqua plants will clean the water. Create bioretention and support beneficial insects. In common, plants Improve air quality.

Create and protect ecology: Choose different types of native plants to protect the local ecological system.

Aesthetic purpose: Choose seasonal flower plants for aesthetic purpose.

The overall plant selection will consider promoting local fruits and edible plants. This area will become an educational center for the city children to learn about local fruits and to provide nourishment for the street children.

A list is provided to present the varieties of local fruits as an example. 


\subsection{List of fruit plants}

\begin{tabular}{|c|c|c|c|}
\hline English name & Common name & Scientific name & Season \\
\hline Jackfruit & Kathal & $\begin{array}{l}\text { Artocarpus } \\
\text { heterophylus }\end{array}$ & Summer \\
\hline Mango & $\mathrm{Am}$ & Mangifera indica & Summer \\
\hline Litchi & Litchi & Litchi chinensis & Summer \\
\hline Watermelon & Tarmuj & Citrullis lanatus & Summer \\
\hline Burmese grape & Lotkon & Baccaurea motleyana & Summer \\
\hline Yellow mombin & Amra & Spondias mombin & Summer \\
\hline Pineapple & Anaras & Ananus comosus & Summer \\
\hline Guava & Payara & Psidium sativum & $\begin{array}{ll}\begin{array}{l}\text { Summer/ All } \\
\text { season }\end{array} & \text { All } \\
\end{array}$ \\
\hline Blackberry & kalo Jam & Belamcanda chinensis & Summer \\
\hline Wood Apple & Kodbel & Limonia acidissima & Summer \\
\hline Elephant Apple & Chalta & Dillenia indica & Summer \\
\hline Lemon & Lemon & Citrus limon & Summer \\
\hline Star Fruit & Kamranga & Averrhoa carambola & Summer \\
\hline Amla/ Emblic & Amloki & Phyllanthus emblica & Summer \\
\hline Wood apple & Beal & Aegel mermelos & Winter \\
\hline water apple & Jamrul & Syzygium aqueum & Winter \\
\hline Pomegranate & Dalim & Punica granatum & Winter \\
\hline Orange & Komla & Citrus sinensis & Winter \\
\hline Jujube fruit & Boroi & $\begin{array}{l}\text { Zigyphus mauritiana } \\
\text { Lamk }\end{array}$ & Winter \\
\hline Banana & Kola & Musa sapientum & All season \\
\hline Papaya & Papaya & Carica papaya & All season \\
\hline Coconut & Narikel & Cocos nucifera & All season \\
\hline
\end{tabular}




\section{Images of fruit trees}
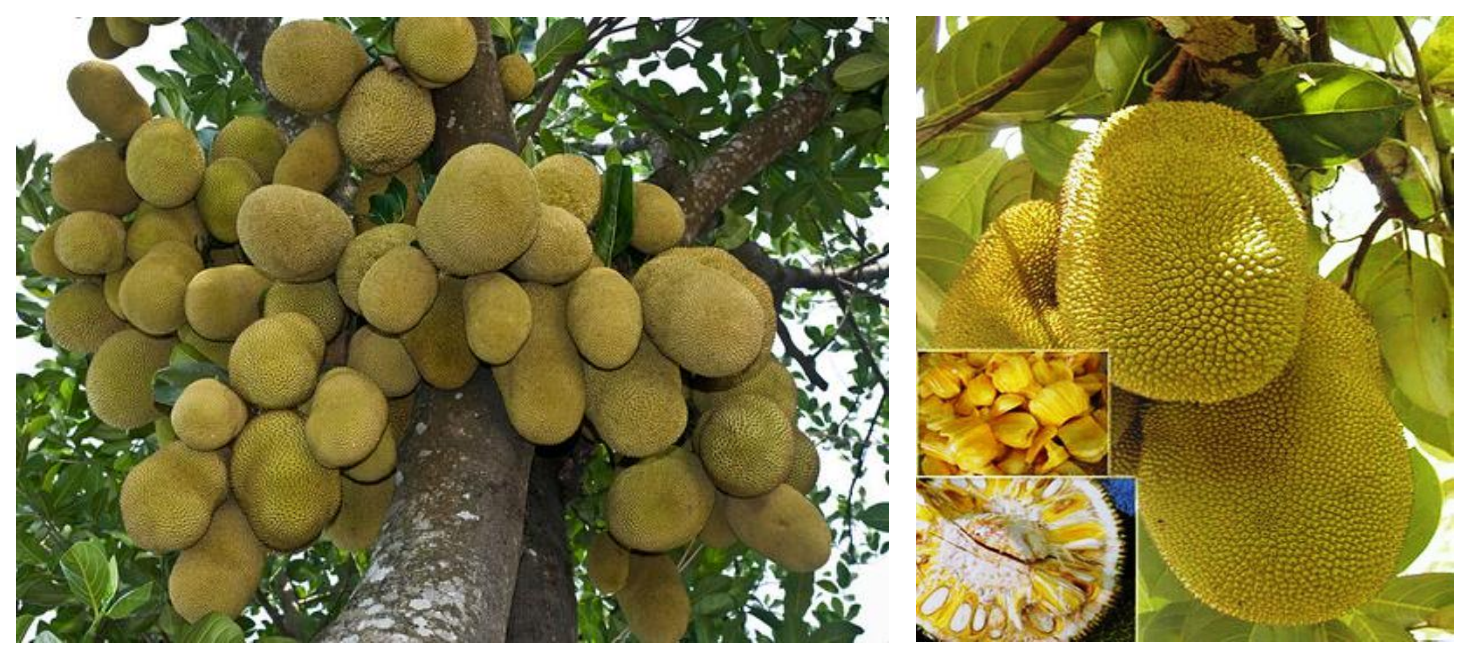

Figure 107: Jackfruit tree and fruits
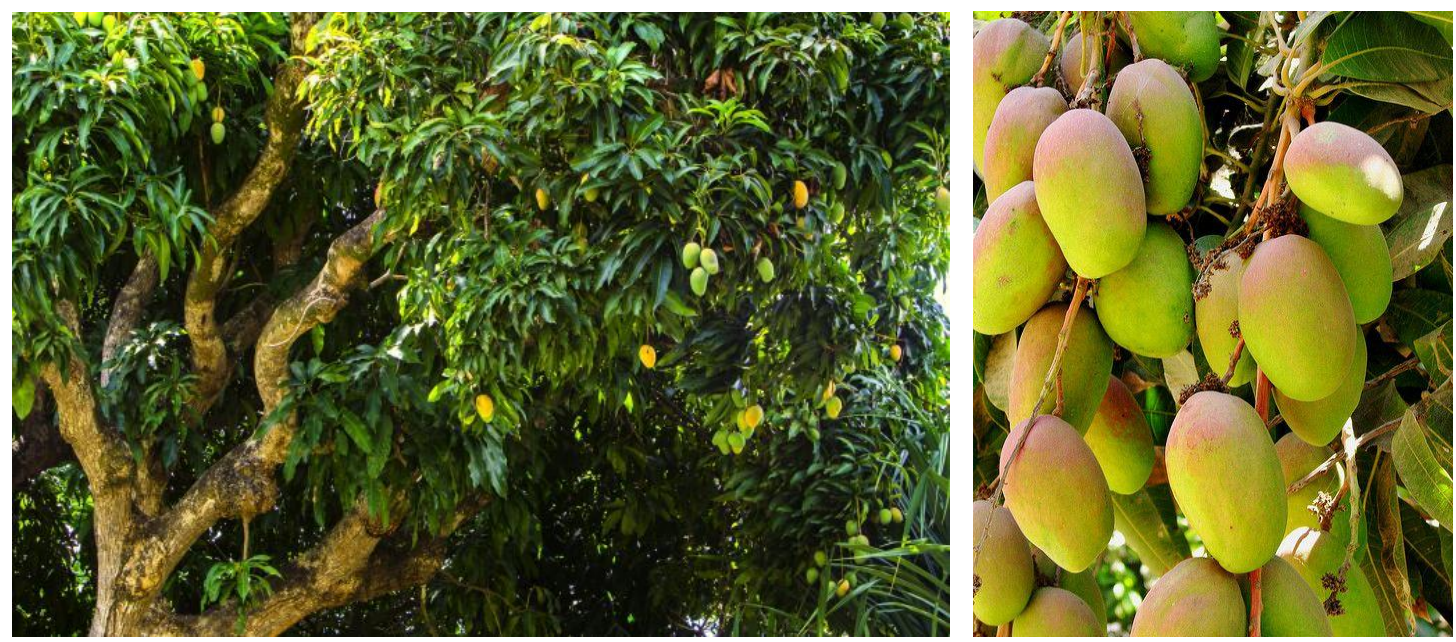

Figure 108: Mangoo tree and fruits
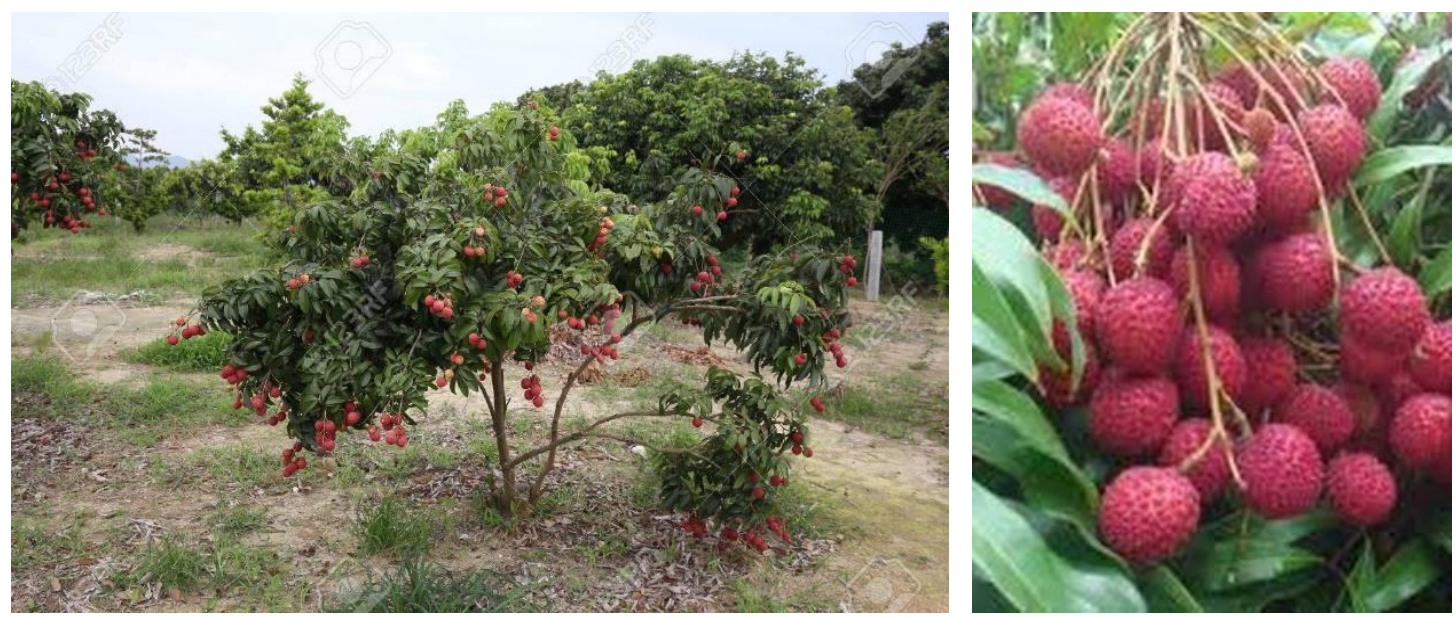

Figure 109: Litchi Tree and fruits 

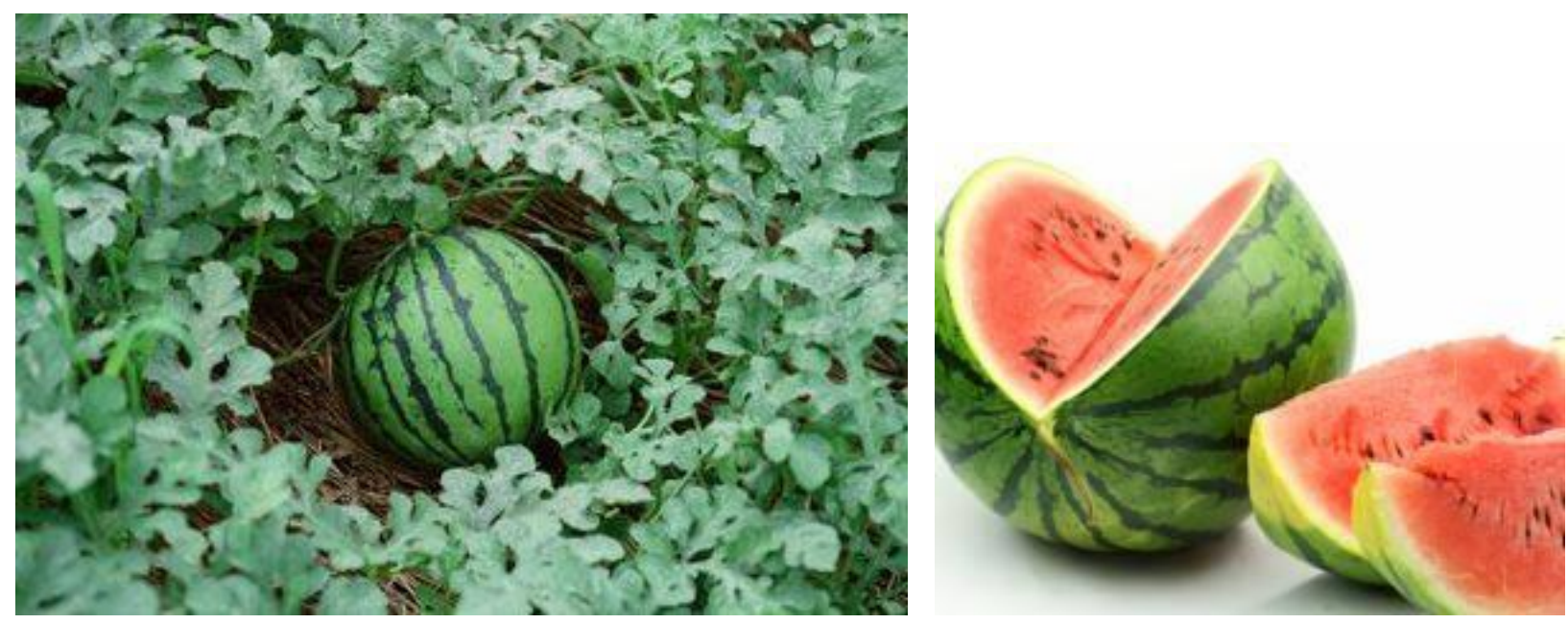

Figure 110: Watermelon Plant and fruit
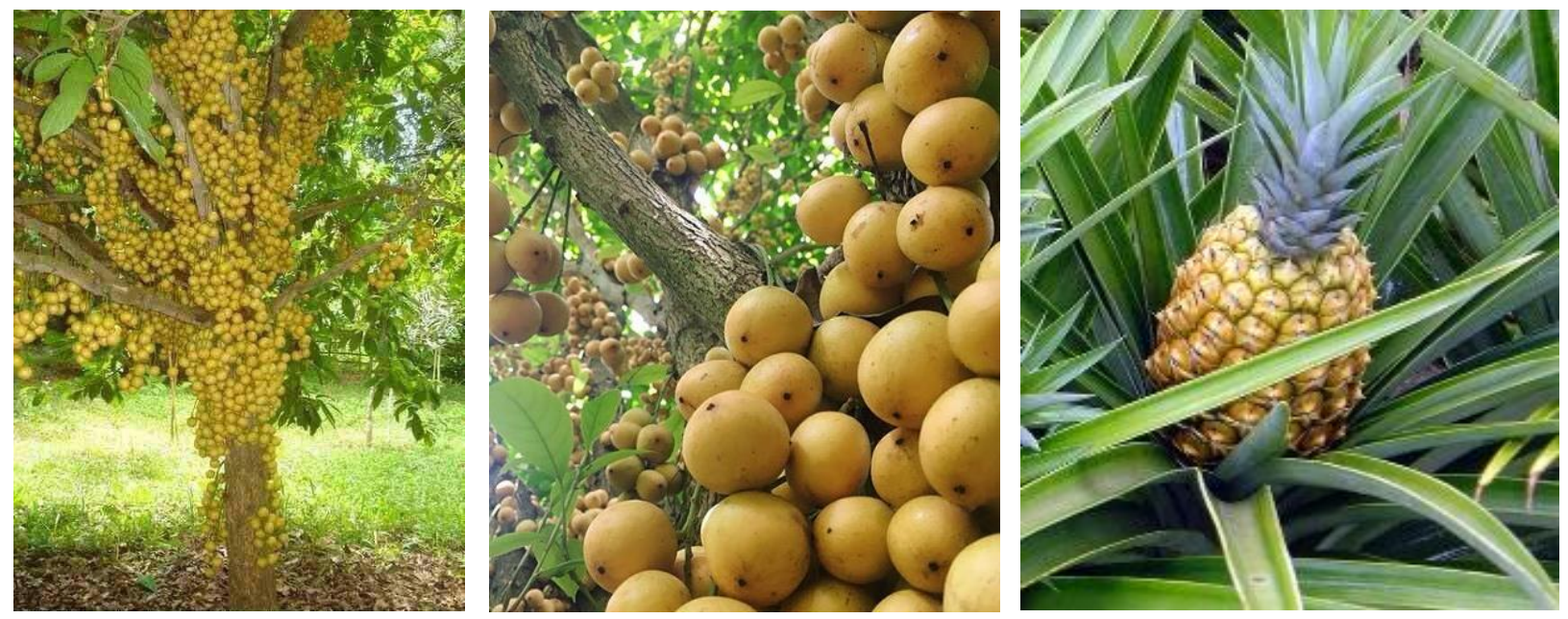

Figure 111: Burmese grape tree and fruit, Pineapple plants and fruits
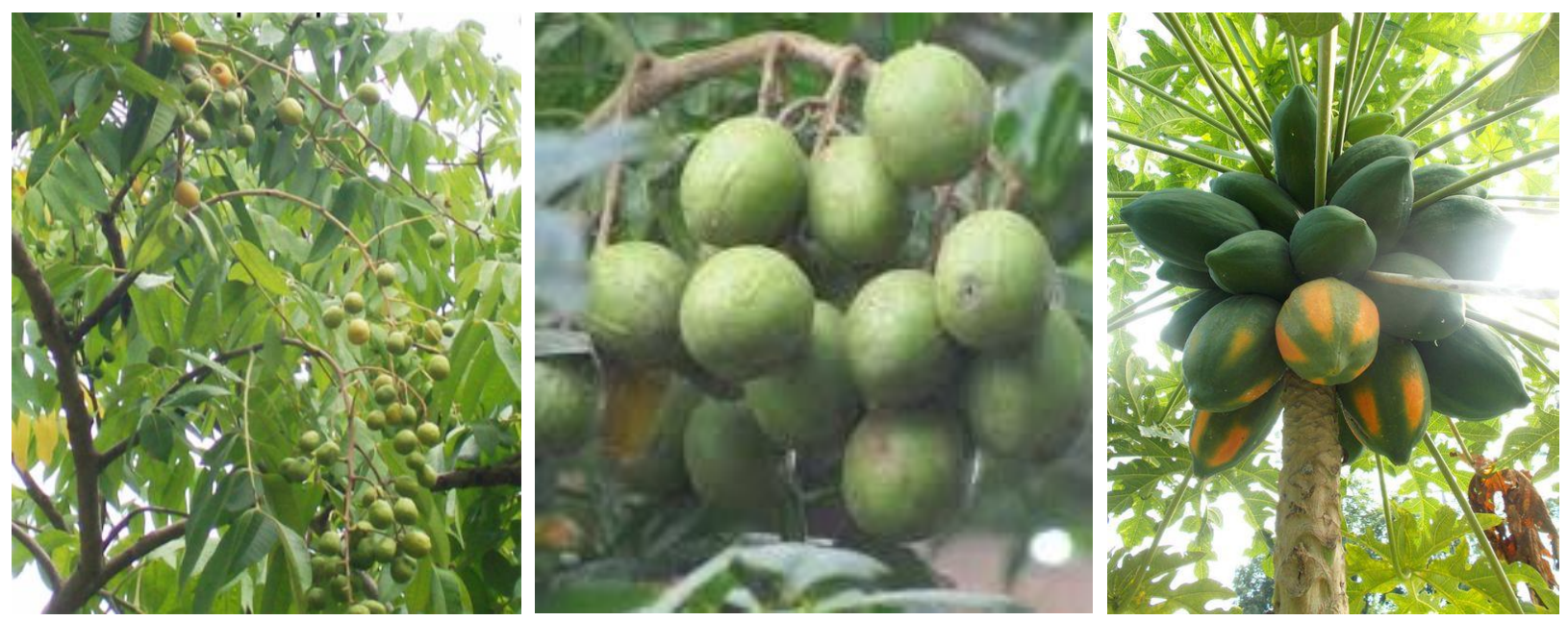

Figure 112: Yellow mombin tree and fruits, Papaya plants and fruits 

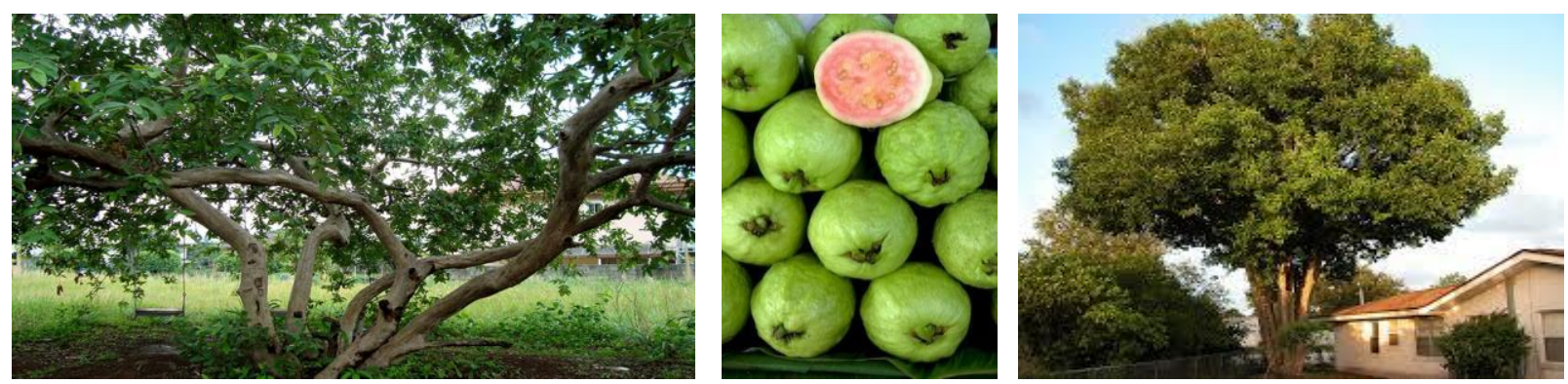

Figure 113: Guava tree and fruits, Blackberry tree
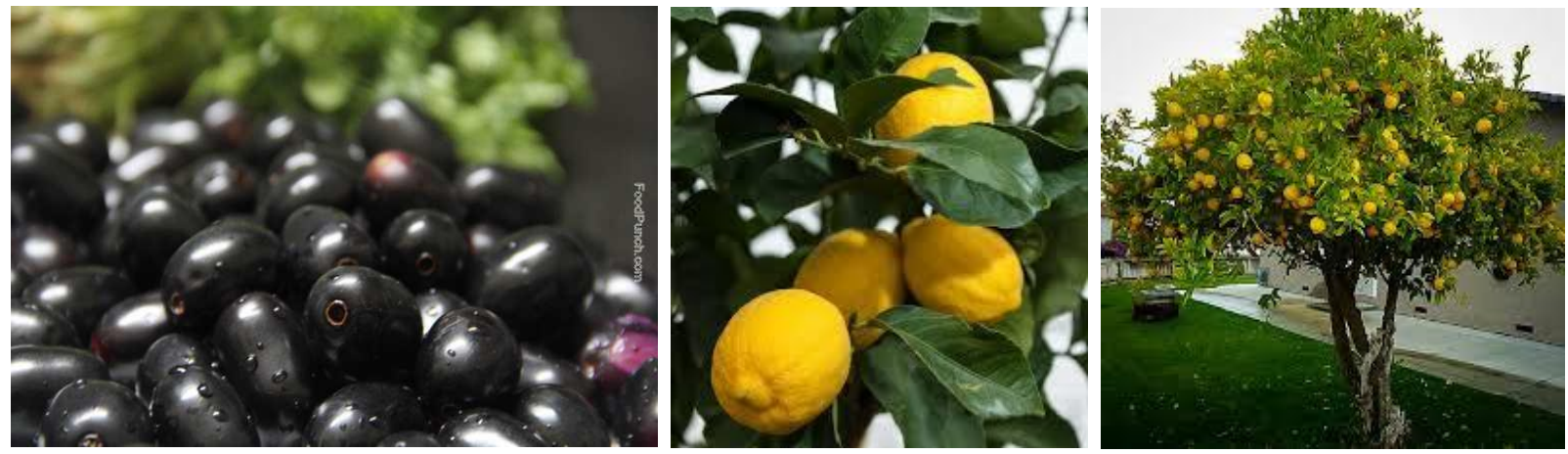

Figure 114: Blackberry fruits, Lemon tree and fruits
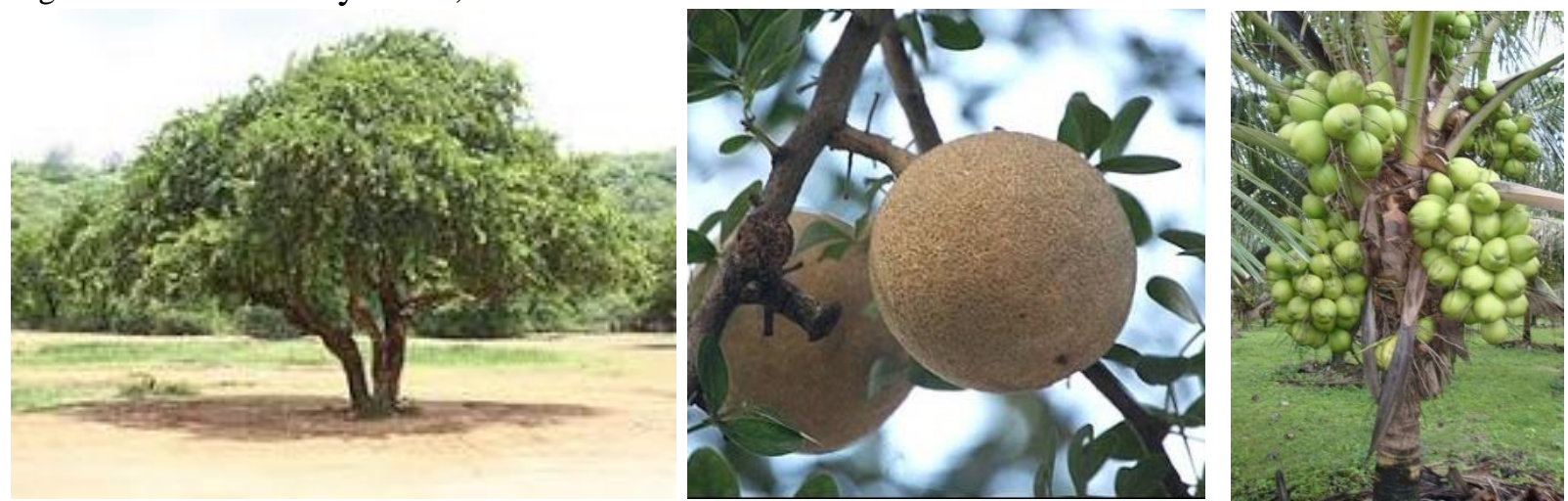

Figure 115: Wood Apple tree and fruits, Coconut plants
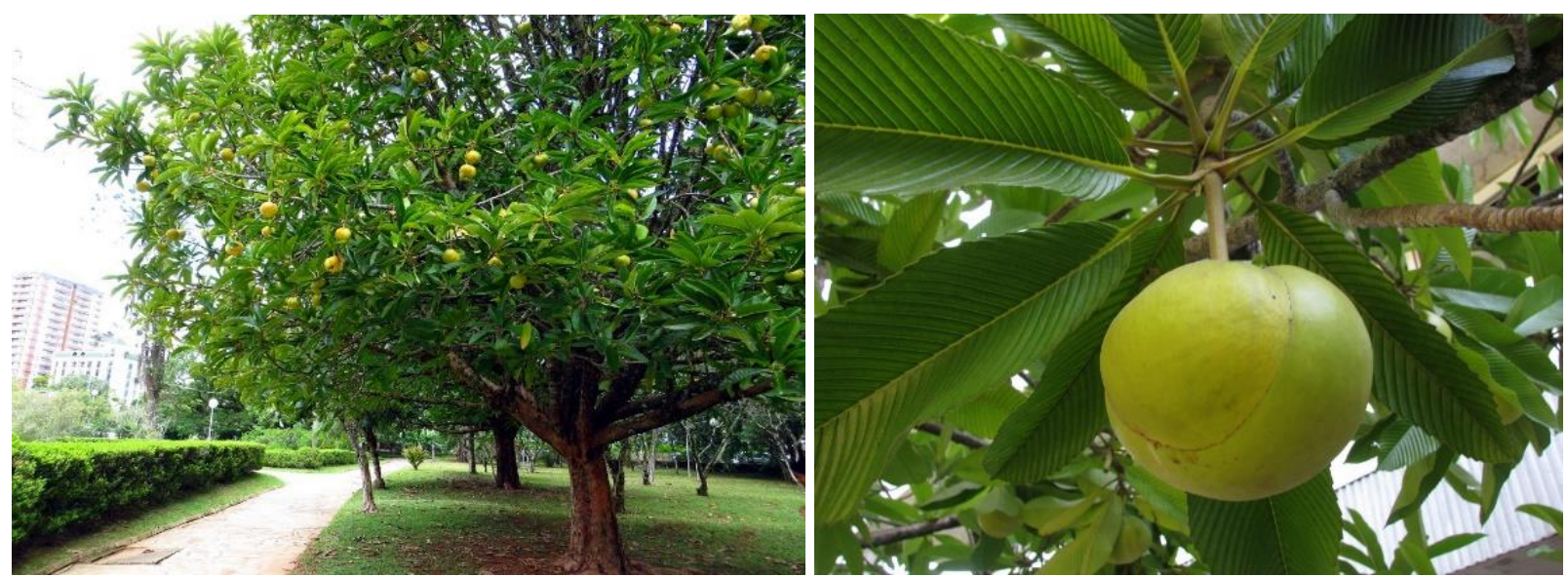

Figure 116: Elephant Apple tree and fruits 

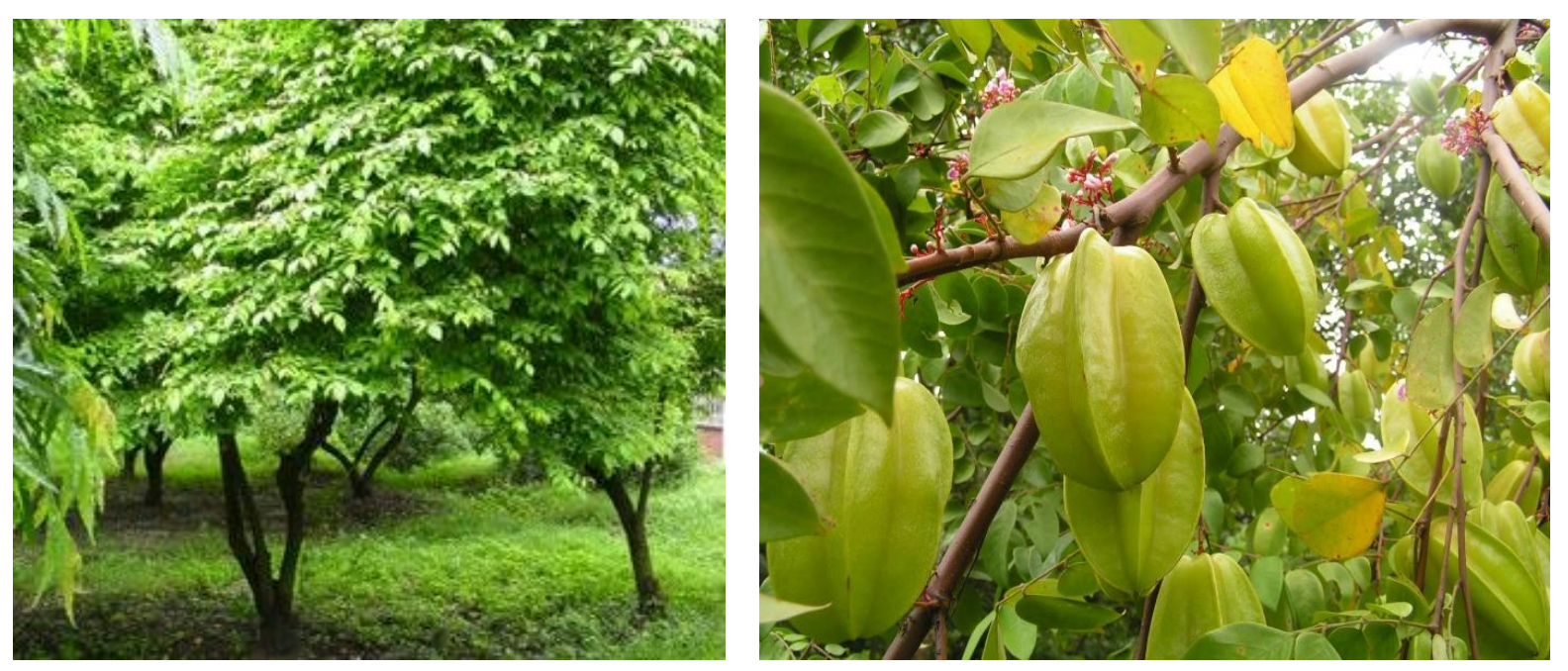

Figure 117: Star Fruit tree and fruits
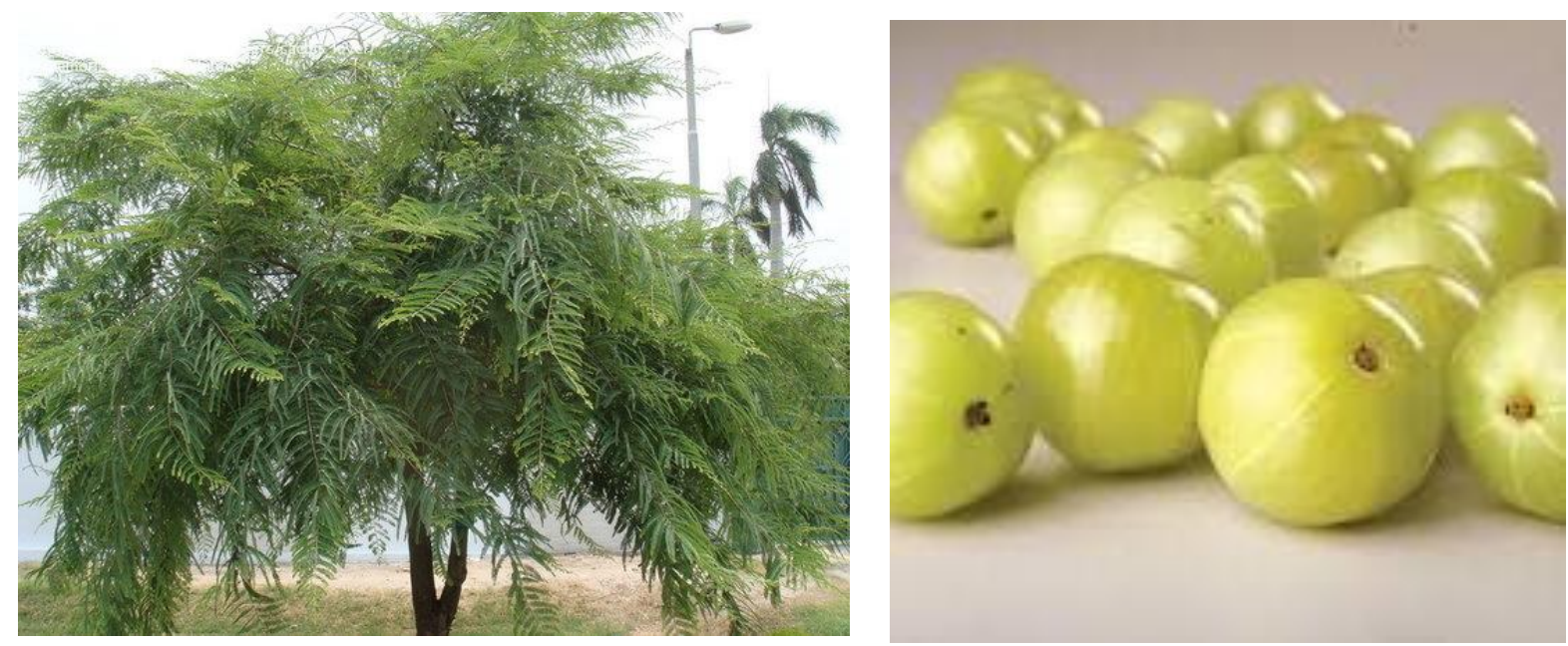

Figure 118: Amla tree and fruits
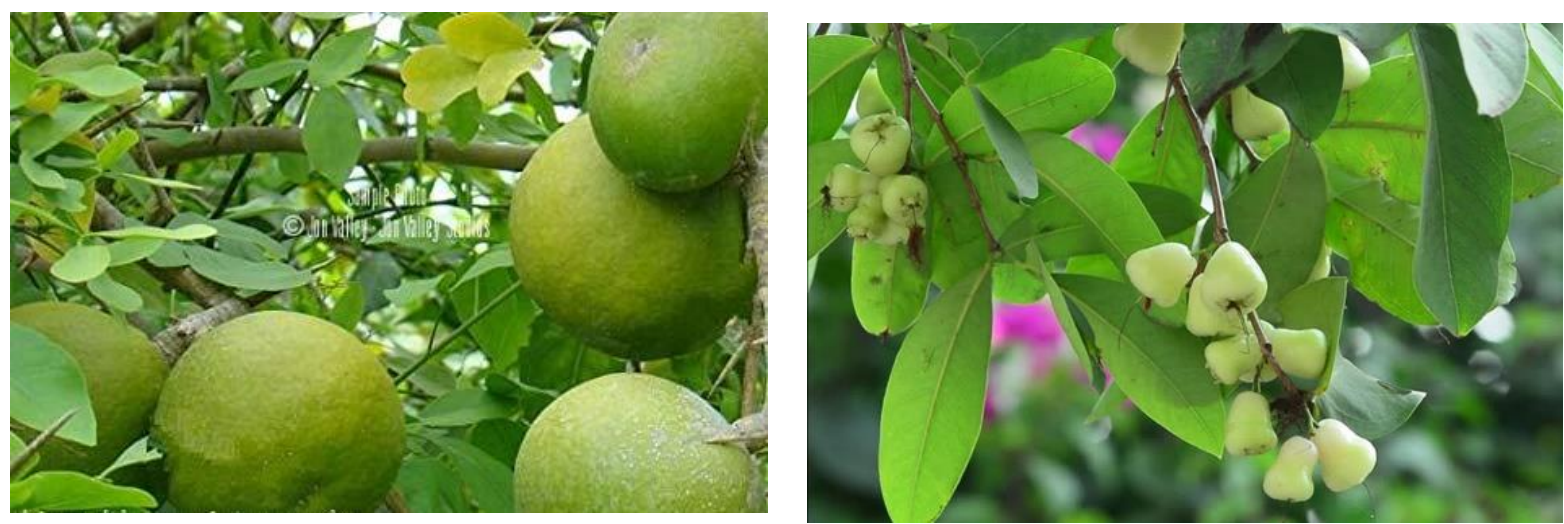

Figure 119: Wood apple fruits and water apple fruits 

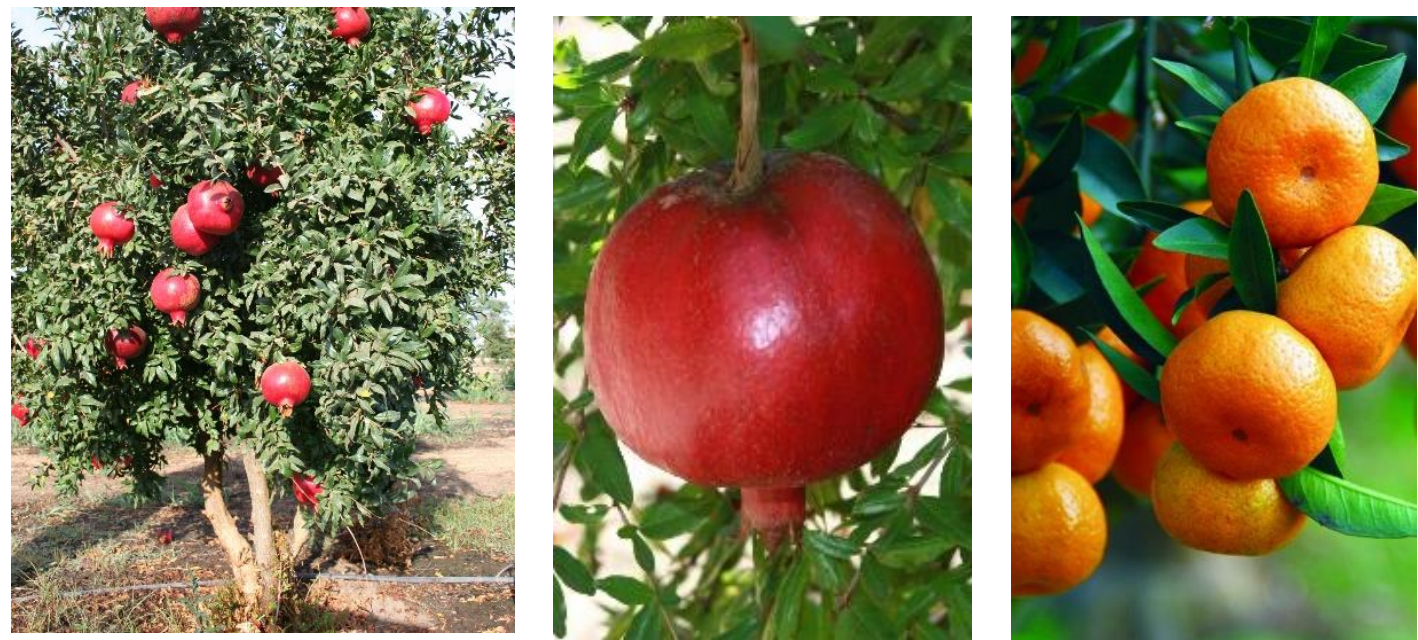

Figure 120: Pomegranate tree and fruit, Orange fruits
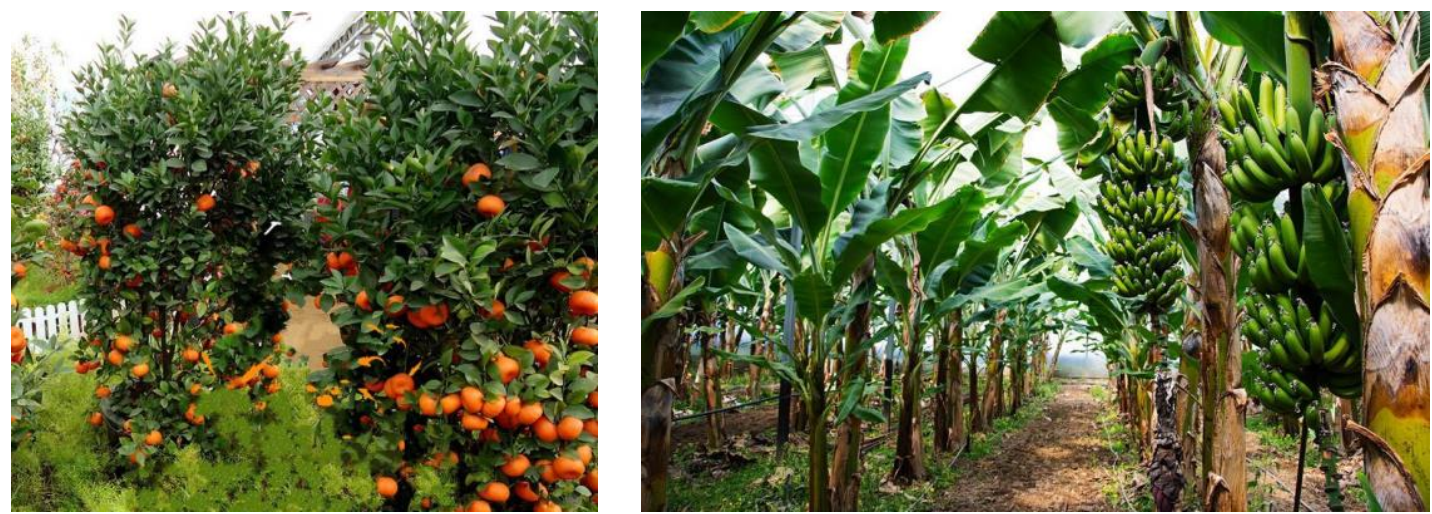

Figure 121: Orange fruit tree, Banana plants
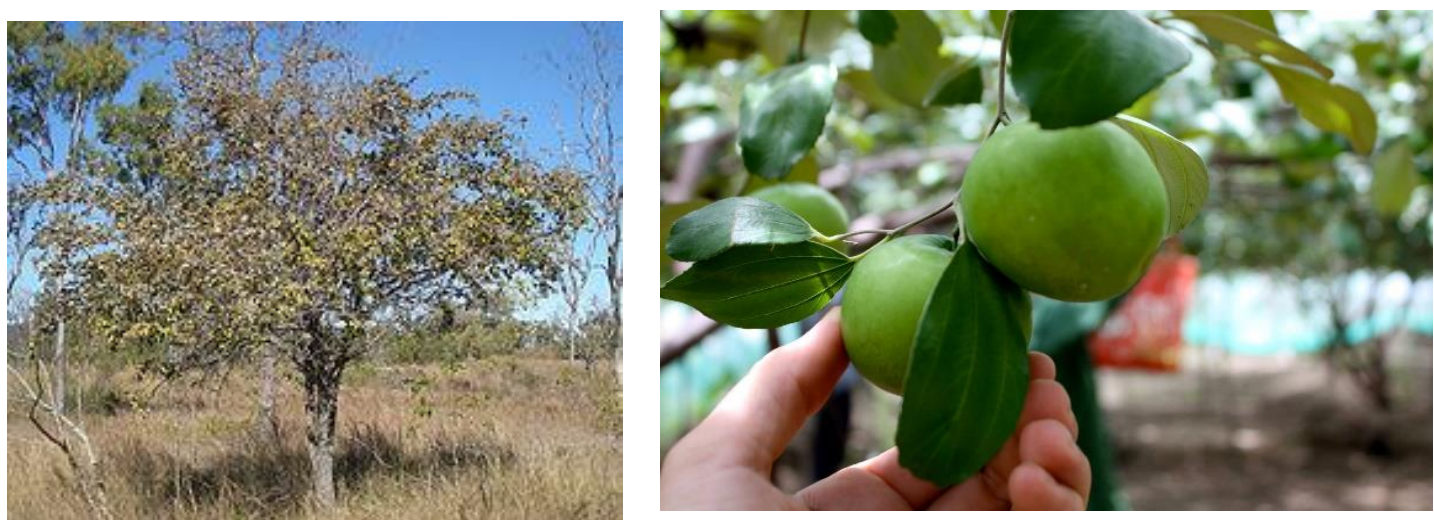

Figure 122: Jujube fruit tree and fruits 


\subsection{Planting Style}

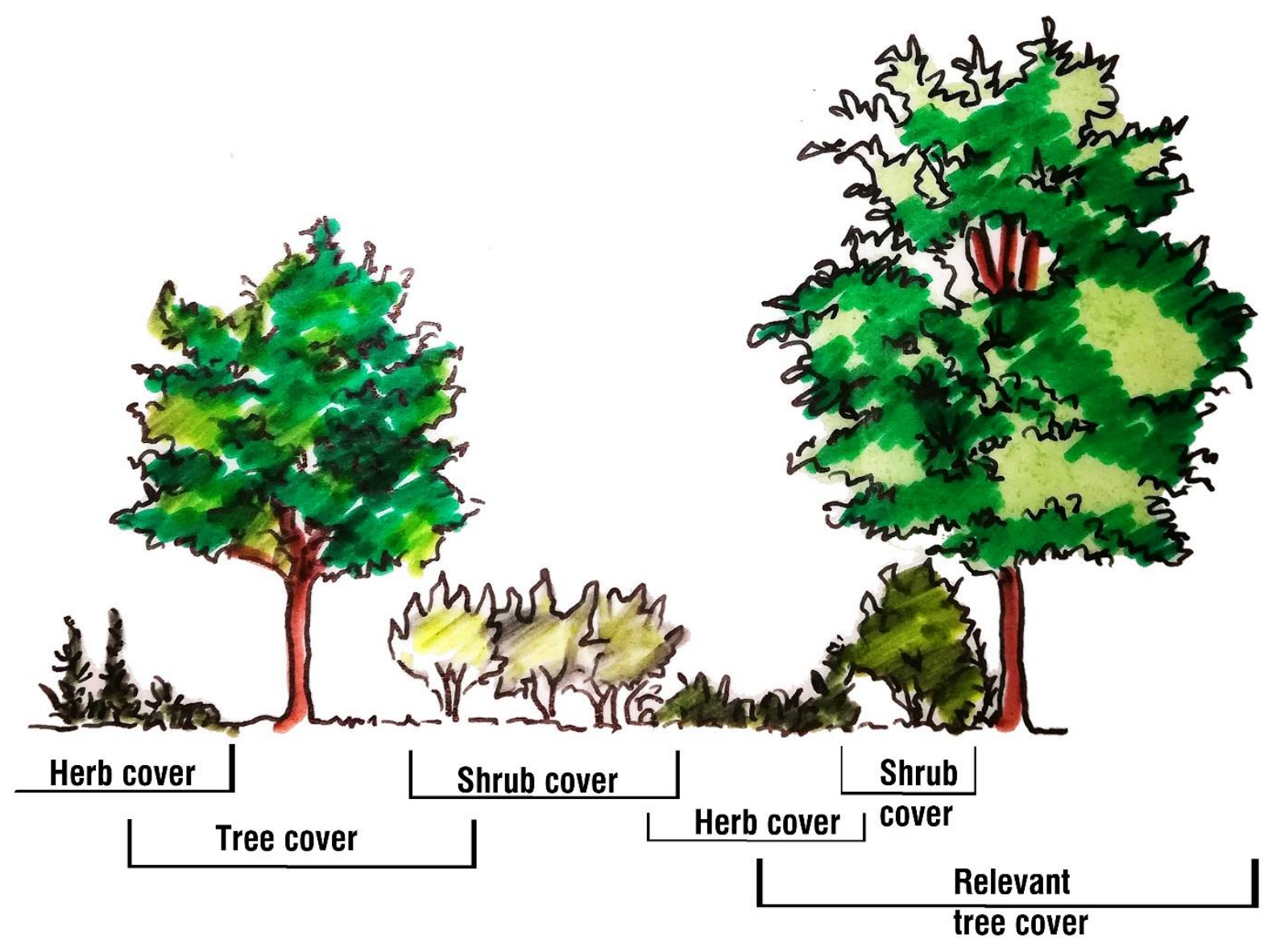

Figure 123: Planting style

Figure 123 and 124 and y shows the planting style here. It is good to plant a fruit tree in combination with other companion plants that will grow together to create an ecosystem around the tree. This system is called permaculture method. Though there has not been a lot of research for fruit trees planting guide, but the researcher has shown that planting more than one species together can increase yields and crops' health. It is also space saving and good for wildlife and ecosystem.

The first step is to select the type of tree to start with. It is important to know about the growth pattern, mature size of that tree, the soil types it prefers, any disease and pest problems for that tree.

Then it is needed to select companion plants. Companion plants are typically made up of six categories: suppressors, attractors, repellers, mulchers, accumulators, and fixers. There is no rule to plant all of these.

Suppressors suppress weed growth through their own growth pattern. Strawberries are good suppressors. Attractors refers to those plants which attract pollinators and another beneficial insect to the tree (Planning a Fruit Tree Guild, 2018). Repellers are plants which job is to repel unwanted 
pests from a fruit tree. Almost any allium like garlic, perennial onions, lemon grass are used to repel pests (Planning a Fruit Tree Guild, 2018). Fixers are plants that add nitrogen to the soil as they grow. Mulchers are cover crops. Accumulators refer to those plants that bring nutrients from deep in the soil to the surface to make nutrients accessible for other plants.

It is good to maintain various height difference to search for component plants as they will not compete for light with main trees (Figure 124).

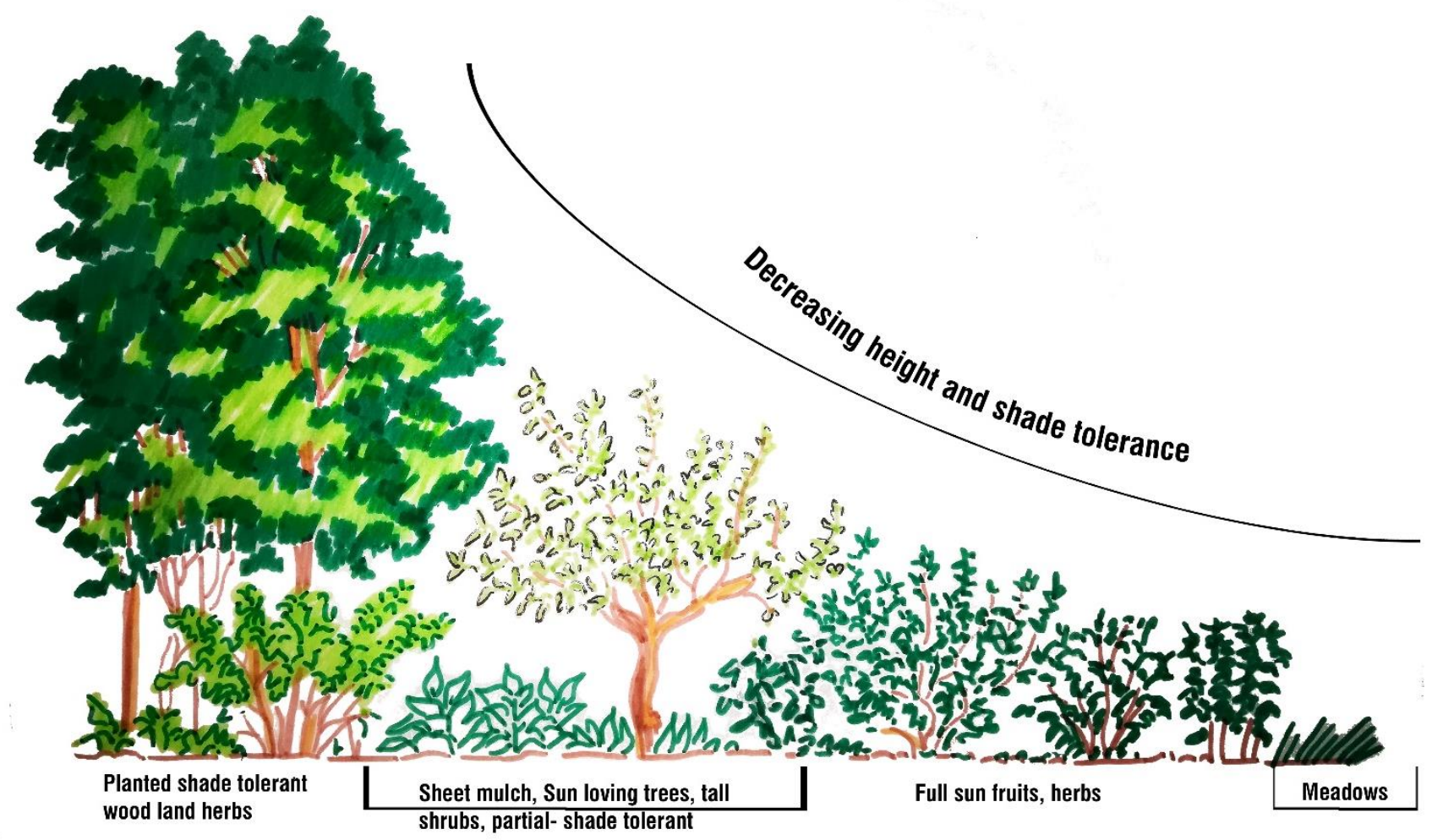

Figure 124: Planting style

\section{CロN口LUSIロN}

The main emphasis of this study is to develop a process to plan regarding a vehicular road converting it into its previous historic look in the purpose of mitigating inundation rate for the surrounding areas. This process can be an example for another similar kind of situation throughout the whole city, as waterlogging is one of those major problems for which people suffer more. The most positive aspect of this study is to protect the water bodies. If we could not protect the wetlands and water bodies, the drainage system of Dhaka will collapse and many of its areas will be inundated. This study can be a key factor to make dead water lines alive for Dhaka City.

Another positive aspect of this study is to use this waterway as a transportation manner. Water transportation system is the cheapest way among any other transportation system. Improving the 
waterway and using it as a supporting manner with vehicular access can make a tremendous change for whole Dhaka city.

In present days, ArcGIS is a very necessary information system for any kind of professional and academic field. This study has shown that there is a huge lacking in good quality of GIS data for Bangladesh. A detail hydrological and water level survey is necessary to verify the idea of this study. A large amount of good quality of ArcGIS data is needed for that portion. It is really a big challenge for the country like Bangladesh to make a data resource to exhibit this kind of analysis. However, we need a website of GIS data storage, so that student and researchers can get there required data easily for any kind of GIS analysis.

This study is showing a method to reintroduce a lost waterway to solve a present top priority problem, which is water logging for Dhaka City. The procedure and methods of this study will lead to think at a different level. Every step of this process can generate a new dimension of analysis about the overall situation for the City of Dhaka as well as for the country of Bangladesh.

\section{REFERENCES:}

Climate Change and Water Resources. (n.d.). Retrieved April 26, 2019,

from https://www.researchgate.net/publication/235707918_Climate_Change_and_Water_Resour $\underline{\text { ces }}$

Impact of Submergence-Tolerant Rice Varieties on Smallholders' Income and Expenditure: FarmLevel Evidence from Bangladesh. (n.d.). Retrieved April 26, 2019, from https://www.researchgate.net/publication/326263766_Impact_of_SubmergenceTolerant_Rice_Varieties_on_Smallholders\%27_Income_and_Expenditure_FarmLevel_Evidence_from_Bangladesh/figures

Ahmed, B., Hasan, R., \& Maniruzzaman, K. M. (2014). Urban Morphological Change Analysis of Dhaka City, Bangladesh, Using Space Syntax. ISPRS International Journal of GeoInformation, 3(4), 1412-1444. https://doi.org/10.3390/ijgi3041412

Bangladesh All Information: The Division of Bangladesh. (n.d.). Retrieved April 26, 2019, from http://bangladeshallinfoahmod.blogspot.com/2018/03/the-division-of-bangladesh.html

Bangladesh Average Precipitation | 2019 | Data | Chart | Calendar | Forecast. (n.d.). Retrieved April 26, 2019, from https://tradingeconomics.com/bangladesh/precipitation

Bangladesh Population (2019) - Worldometers. (n.d.). Retrieved April 26, 2019, from http://www.worldometers.info/world-population/bangladesh-population/

Bangladesh River Map, Rivers in Bangladesh. (n.d.). Retrieved April 26, 2019, from https://www.mapsofworld.com/bangladesh/bangladesh-river-map.html

Bindu, C. A., \& Mohamed, A. (2016). Water Bodies as a Catalyst to Growth and Development- The Case of Kodungallur Town, Kerala. https://doi.org/10.1016/j.protcy.2016.05.222 
Cars and Bangladeshi floods. (2017, August 2). Retrieved April 26, 2019, from https://www.thedailystar.net/shift/cars-and-bangladeshi-floods-1442107

Datta, U., \& Mandal, D. (2017). CREATING BLUE NETWORK: A SOLUTION OF PRESENT WATER LOGGING AND TRANSPORTATION PROBLEM FOR THE DHAKA METROPOLITAN AREA. In Design that cares - inter disciplinary approach to making built environments efficient and meaningful. Colombo. Retrieved from https://www.researchgate.net/publication/326410342_CREATING_BLUE_NETWORK_A _SOLUTION_OF_PRESENT_WATER_LOGGING_AND_TRANSPORTATION_PROBLEM _FOR_THE_DHAKA_METROPOLITAN_AREA

Dhaka drainage system needs immediate attention of the authorities, experts say. (2015, September 3). Retrieved April 26, 2019, from https://www.clickittefaq.com/dhaka-drainage-system-needsimmediate-attention-of-the-authorities-experts-say/

Dhaka needs Climate-smart Policies to Reduce Waterlogging in a Changing Climate. (n.d.). [Text/HTML]. Retrieved April 26, 2019, from http://www.worldbank.org/en/news/feature/2015/12/01/dhaka-needs-climate-smartpolicies-to-reduce-waterlogging-in-a-changing-climate

Dilip Kumar Datta. (2015). ENVIRONMENTAL AND CLIMATE CHANGE ISSUES OF SW BANGLADESH: THEIR PLIGHTS IN CONSANGUINEOUS POLICY DOCUMENTS. Retrieved from https://www.researchgate.net/publication/326550528_ENVIRONMENTAL_AND_CLIMA TE_CHANGE_ISSUES_OF_SW_BANGLADESH_THEIR_PLIGHTS_IN_CONSANGUINEO US_POLICY_DOCUMENTS

Do What Season Occur Floods. (n.d.). Retrieved April 26, 2019, from https://cellcode.us/quotes/dowhat-season-occur-floods.html

Faisal Hossain, A. H. S.-E.-A., Liton Chandra Mazumder, S. M. S., Sylvain Biancamaria, H. L., \& C. K. Shum. (2013). Proof of Concept of an Altimeter-Based River Forecasting System for Transboundary Flow Inside Bangladesh. IEEE JOURNAL OF SELECTED TOPICS IN APPLIED EARTH OBSERVATIONS AND REMOTE SENSING. Retrieved from https://www.researchgate.net/profile/Liton_Mazumder/publication/260518800_Proof_of_C oncept_of_an_Altimeter-

Based_River_Forecasting_System_for_Transboundary_Flow_Inside_Bangladesh/links/555d80a 508ae8c0cab2ad3e5.pdf

Fazal, S., \& Amin, A. (2011). Impact of Urban Land Transformation on Water Bodies in Srinagar City, India. Journal of Environmental Protection, 02, 142. https://doi.org/10.4236/jep.2011.22016

G.M.J. HASAN, M. A. I. C., \& S. AHMED. (2014). Analysis of the statistical behaviour of daily maximum and monthly average rainfall along with rainy days variation in Sylhet, Bangladesh. Journal of Engineering Science and Technology 9(5):559-573. Retrieved from https://www.researchgate.net/publication/274392902_Analysis_of the_statistical_behaviou 
r_of_daily_maximum_and_monthly_average_rainfall_along_with_rainy_days_variation_in_Syl $\underline{\text { het_Bangladesh }}$

Green-Blue Infrastructure for Urban Climate Adaptation - ppt download. (n.d.). Retrieved April 26, 2019, from https://slideplayer.com/slide/13790965/

Manteghi, G., Limit, H., \& Remaz, D. (2015). Water Bodies an Urban Microclimate: A Review. Modern Applied Science, 9(6), p1. https://doi.org/10.5539/mas.v9n6p1

Novotny, V., Clark, D., \& Griffin, R. (n.d.). Urban Watershed/Water Body Restoration - The Driving Forces. Retrieved from http://www.tucson.ars.ag.gov/ICRW/Proceedings/Novotny.pdf

Overview - Maps. (n.d.). Retrieved April 26, 2019, from https://www.usgs.gov/products/maps/overview

Rahman, K. M. A., \& Zhang, D. (2018). Analyzing the Level of Accessibility of Public Urban Green Spaces to Different Socially Vulnerable Groups of People. Sustainability, 10(11), 3917. https://doi.org/10.3390/su10113917

Remote Sensing \& GIS Based Spatio-Temporal Change Analysis of Wetland in Dhaka City, Bangladesh. (n.d.). Retrieved April 26, 2019, from http://file.scirp.org/Html/19401374_8678.htm

Subir Bairagi, H. B., \& Subrata Kumar Das, S. M. (2018). Impact of Submergence-Tolerant Rice Varieties on Smallholders' Income and Expenditure: Farm-Level Evidence from Bangladesh. Presented at the 2018 Agricultural \& Applied Economics Association Annual Meeting. Retrieved from https://www.researchgate.net/publication/326263766_Impact_of_SubmergenceTolerant_Rice_Varieties_on_Smallholders\%27_Income_and_Expenditure_FarmLevel_Evidence from_Bangladesh

Maathuis, B., Mannaerts, C. M., \& Khan, N. (1999). Evaluating Urban Stormwater Drainage Using GIS and RS Techniques-A Case Study in Dhaka, Bangladesh. Retrieved from https://www.researchgate.net/publication/249045059_Evaluating_Urban_Stormwater_Drai $\underline{\text { nage_Using_GIS_and_RS_Techniques-A_Case_Study_in_Dhaka_Bangladesh }}$

Masiero, É. (n.d.). Influence of a Water body in the Urban Microclimate. Presented at the PLEA2012 - 28th Conference, Opportunities, Limits \& Needs Towards an environmentally responsible architecture. Retrieved from https://www.researchgate.net/publication/284032657_Influence_of_a_Water_body_in_the $\underline{\text { Urban_Microclimate }}$

Mowla, Q., \& Islam, S. (n.d.). Natural Drainage System and Water Logging in Dhaka: Measures to address the Problems. Journal of Bangladesh Institute of Planners, Vol. 6, December 2013, pp. 23-33. Retrieved from https://www.researchgate.net/publication/324212561 Assessment of people's perception _on_water_logging_in_Chittagong_city_corporation_area_Bangladesh 
Sultana, M. S., Islam, G. M. T., \& Islam, Z. (2009). Pre- and Post-Urban Wetland Area in Dhaka City,Bangladesh: A Remote Sensing and GIS Analysis. Journal of Water Resource and Protection, 01, 414. https://doi.org/10.4236/jwarp.2009.16050

Yang, B., Meng, F., Ke, X., \& Ma, C. (2015). The Impact Analysis of Water Body Landscape Pattern on Urban Heat Island: A Case Study of Wuhan City [Research article]. https://doi.org/10.1155/2015/416728

Peeters, S., \& Shannon, K. (n.d.). Readdressing Dhaka's Public Water Bodies: A Design Research Readdressing Dhaka's Public Water Bodies: A Design Research. Retrieved from https://www.researchgate.net/publication/265941623_Readdressing_Dhaka\%27s_Public Water_Bodies_A_Design_Research_Readdressing_Dhaka\%27s_Public_Water_Bodies_A_Desig $\underline{\mathrm{n} \_ \text {Research }}$ 